University of Louisville ThinkIR: The University of Louisville's Institutional Repository

Electronic Theses and Dissertations

$12-2015$

\title{
Iconoclastic fervor : Sally Hazelet Drummond, abstract expressionism and curatorial practice.
}

Hillary Sullivan

University of Louisville

Follow this and additional works at: https://ir.library.louisville.edu/etd

Part of the Modern Art and Architecture Commons, Other Feminist, Gender, and Sexuality Studies Commons, Other History of Art, Architecture, and Archaeology Commons, and the Theory and Criticism Commons

\section{Recommended Citation}

Sullivan, Hillary, "Iconoclastic fervor : Sally Hazelet Drummond, abstract expressionism and curatorial practice." (2015). Electronic Theses and Dissertations. Paper 2333.

https://doi.org/10.18297/etd/2333

This Master's Thesis is brought to you for free and open access by ThinkIR: The University of Louisville's Institutional Repository. It has been accepted for inclusion in Electronic Theses and Dissertations by an authorized administrator of ThinkIR: The University of Louisville's Institutional Repository. This title appears here courtesy of the author, who has retained all other copyrights. For more information, please contact thinkir@louisville.edu. 
ICONOCLASTIC FERVOR: SALLY HAZELET DRUMMOND, ABSTRACT EXPRESSIONISM AND CURATORIAL PRACTICE

BY:

Hillary Sullivan

B.A., Utah State University, 2012

\begin{abstract}
A Thesis
Submitted to the Faculty of the

College of Arts and Sciences of the University of Louisville

In Partial Fulfillment of the Requirements

For the Degree of

Master of Arts in

Art(c) and Art History Critical and Curatorial Studies
\end{abstract}

Hite Art Institute

Department of Fine Arts

University of Louisville

Louisville, KY

December 2015 
Copyright 2015 by Hillary Sullivan

All Rights Reserved 

ICONOCLASTIC FERVOR: SALLY HAZELET DRUMMOND, ABSTRACT EXPRESSIONISM AND CURATORIAL PRACTICE

\author{
BY \\ Hillary Sullivan \\ B.A., Utah State University, 2012
}

A Thesis Approved on

November 19, 2015

By the following Thesis Committee:

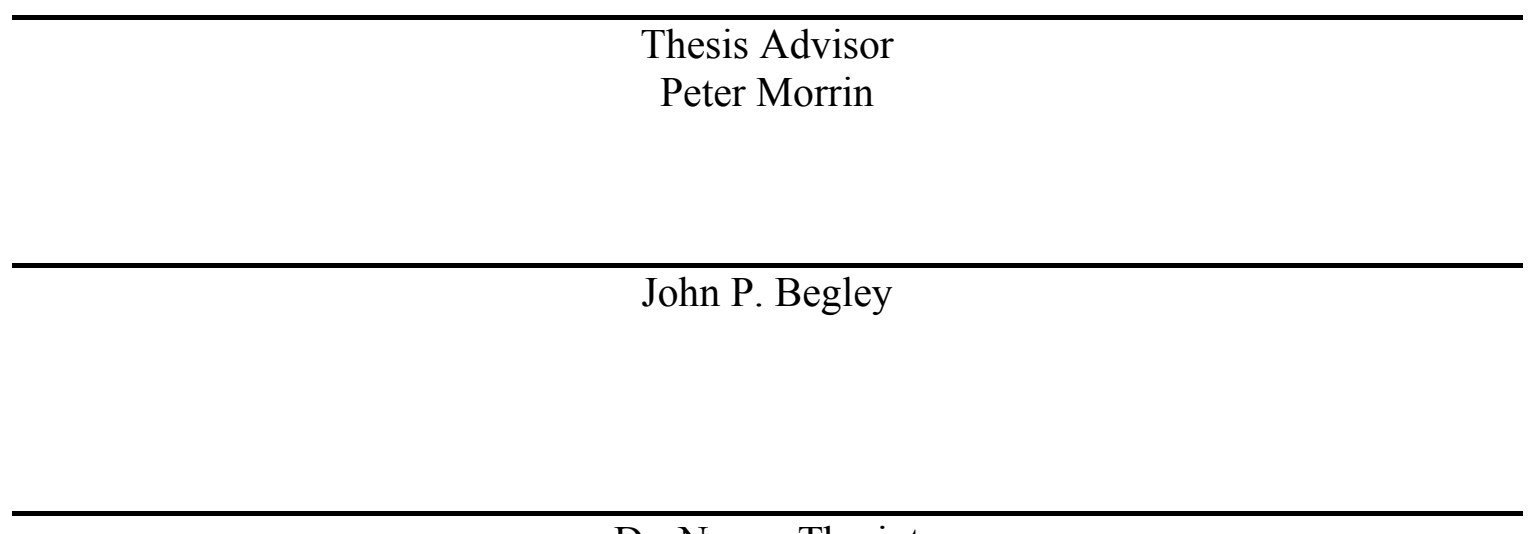

Dr. Nancy Theriot 


\section{DEDICATION}

This thesis is dedicated to my husband, Raymond Jay Sullivan and to my parents, Pamela and Tony Thomas for their unwavering encouragement and support, especially during the transformative experience that is graduate school. 


\section{ACKNOWLEDGEMENTS}

I would first like to express my overwhelming gratitude for my teachers and advisors, John Begley and Peter Morrin. I am indebted to their dedication to art and museology and am inspired by their passion. I am most appreciative to John and Kay Begley for making the trip to New York on my behalf to pick up artwork-neither of you could ever understand how grateful I am. Thanks are also owed to Peter Morrin for giving me the latitude to follow my own scholarly interests. To John and Peter, the importance of these contributions, along with the many others throughout my study at the University of Louisville, cannot be overstated. I am also indebted to committee member, Dr. Nancy Theriot, for agreeing to step outside of her area of expertise to provide insights on this project.

From the Hite Art Institute, I would like to express my gratitude to the following members: Renèe Murphy for her assistance with the public relations of the exhibition and to Linda Rowley for managing the finances and paperwork. I am also greatly indebted to Amy Fordham for her overwhelming kindness and friendship throughout my graduate time. From the Margaret M. Bridwell Art Library I would like to thank Sarah Carter, Kathy Moore and Trish Blair for their patience and persistence in answering all of my questions and for the numerous times I shuffled books. For installation and deinstallation support, thesis guidance and photography, I am grateful to Jessica Kincaid. 
I am also forever indebted to Raymond Jay Sullivan and to Pamela and Tony Thomas for their love and support above and beyond the parameters of this thesis and exhibition. Bailey Mazik is also in this category as the best sounding board I could have ever asked for-your friendship is the best part of graduate school.

Lastly, I would like to express my awe for the artist, Sally Hazelet Drummondmay we all have the courage to embody an iconoclastic fervor. 


\begin{abstract}
ICONOCLASTIC FERVOR: SALLY HAZELET DRUMMOND, ABSTRACT EXPRESSIONISM AND CURATORIAL PRACTICE
\end{abstract}

\title{
Hillary Sullivan
}

November 19, 2015

Sally Hazelet Drummond is the first female to graduate from the Hite Art Institute, earning a master's in painting in 1952. During her study at the University of Louisville she explored Abstract Expressionism. In 1953 Drummond joined the Tanager Gallery, one of the Tenth Street artists' co-ops. In the midst of Willem De Kooning, Ad Reinhardt and Mark Rothko, Drummond refined her work into a simplified, contemplative style that she continued to develop over the course of her life.

Drummond described Abstract Expressionism as a kind of iconoclastic fervor. While history has remembered the style as being characterized largely by wall sized canvases swabbed with gestural marks of the artists or huge fields of color, re-assessment today allows for a much larger perspective that encompasses the avant-gardism of the movement. Drummond continued the iconoclasm of the early abstract expressionists by rejecting these methods of working, creating her own definitive iteration. 


\section{TABLE OF CONTENTS}

ACKNOWLEDGEMENTS .................................................... iv

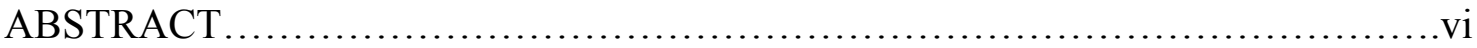

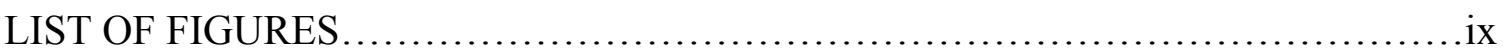

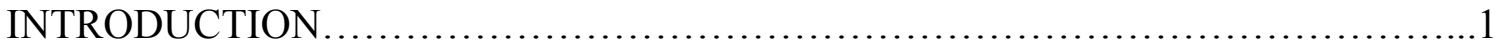

ABOUT THE ARTIST: SALLY HAZELET DRUMMOND ..........................

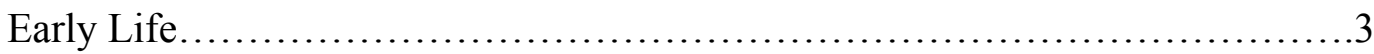

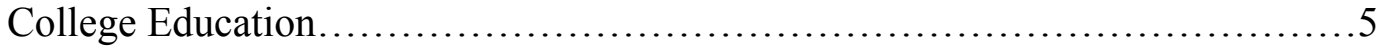

Graduate Work .......................................................... 9

Post-Graduate Work: Italy and the Tanager Gallery ...........................12

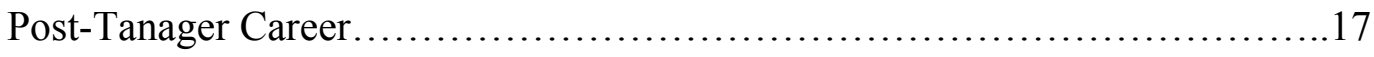

ABSTRACT EXPRESSIONISM: A MOVEMENT, AN IDEOLOGY ..................23

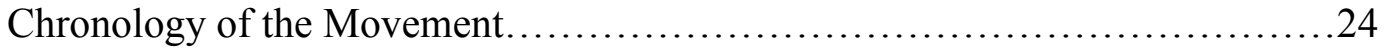

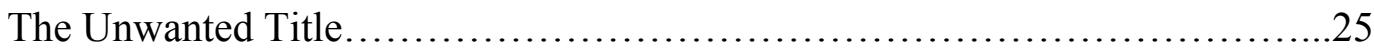

The Origins of Abstract Expressionism.....................................26

Gesture and Color: The Stylistic Tendencies of Abstract Expressionism.........30

The Generations of Abstract Expressionism..................................32

Abstract Expressionism and the Rise of the Art Critic...........................35

A Limited Understanding of the Movement: Tenets and Misconceptions in Abstract Expressionism.................................................... 39

SALLY HAZELET DRUMMOND AS AN ABSTRACT EXPRESSIONIST...........53

Exploration into Abstraction...............................................53

A Break from Conventional Abstract Expressionism...........................63

Community, Spirituality and the 'Painter Lady' ..............................67 
EXHIBITING ICONOCLASTIC FERVOR ..................................... 74

Curatorial Practice................................................... 74

Iconoclastic Fervor, the Exhibition........................................ 79

The Catalogue for Iconoclastic Fervor .................................86

Reflecting on Iconoclastic Fervor.....................................87

CONCLUSION........................................................... 89

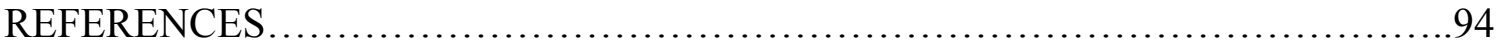

APPENDICES

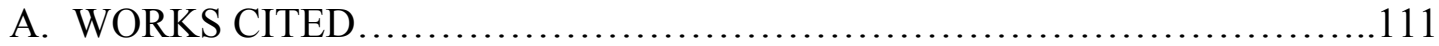

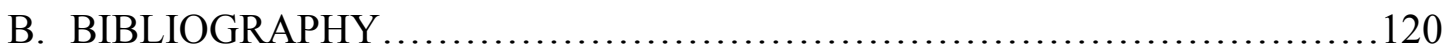

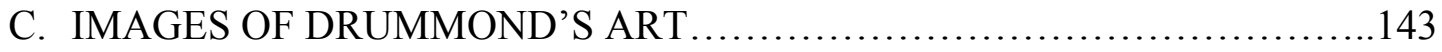

D. GALLERY LAYOUT .............................................. 158

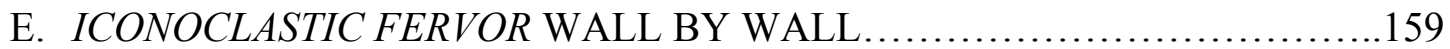

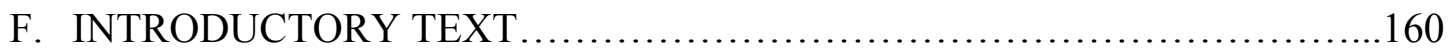

G. OBJECT LABELS ................................................... 161

H. BROCHURE TEXT ................................................ 168

I. QUOTES BY SALLY HAZELET DRUMMOND ..........................

J. CURATORIAL ESSAY ............................................... 170

K. EXHIBITION EVALUATION FORM.................................... 178

L. EXHIBITION PRESS RELEASE.......................................... 179

M. INTERVIEW WITH THE ARTIST ................................... 180

N. CURRICULUM VITAE FOR SALLY HAZELET DRUMMOND..............262

CURRICULUUM VITAE...................................................266 


\section{LIST OF FIGURES}

IMAGE

PAGE

1. Sally Hazelet Drummond, Girl Sitting, ca. 1940......................143

2. Sally Hazelet Drummond, Girl in a Doorway, 1949..................144

3. Sally Hazelet Drummond, Magician, $1951 \ldots \ldots \ldots \ldots \ldots \ldots \ldots \ldots \ldots . \ldots . \ldots . \ldots 145$

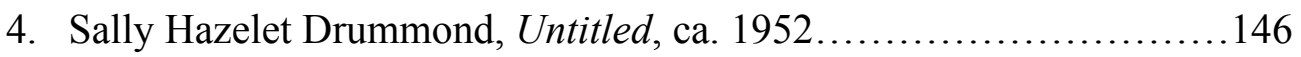

5. Sally Hazelet Drummond, Bluebird, 1960.........................147

6. Sally Hazelet Drummond, Heart of Iron, ca. $1960 \ldots \ldots \ldots \ldots \ldots . . . . . . . . .148$

7. Sally Hazelet Drummond, A Simple Arrangement, $1969 . \ldots . . . . . . . . . .149$

8. Sally Hazelet Drummond, Union Place, 1978.......................150

9. Sally Hazelet Drummond, Night Flight, 1978....................151

10. Sally Hazelet Drummond, Unified Field, 1980.....................152

11. Sally Hazelet Drummond, Daisy Newman, 1984-1985...............153

12. Sally Hazelet Drummond, No Separation, 1991.....................154

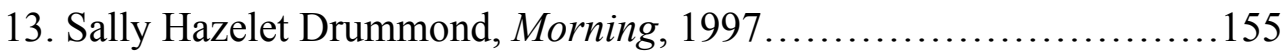

14. Sally Hazelet Drummond, Untitled (Gold Leaf), 2010................156

15. Sally Hazelet Drummond, Blue Painting, $1957 \ldots \ldots \ldots \ldots \ldots \ldots \ldots . . . . . . . .157$ 


\section{INTRODUCTION}

This thesis was written in conjunction with the exhibition Iconoclastic Fervor: Sally Hazelet Drummond's Road to Abstraction, which was held at the Hite Art Institute Galleries at the University of Louisville from November $19^{\text {th }}$ to December $18^{\text {th }}, 2015$. Hillary Sullivan completed the thesis and exhibition in partial fulfillment of the requirements to obtain a Master's of Arts in Critical and Curatorial Studies at the University of Louisville.

In her 1952 master's thesis for the University of Louisville, Drummond described Abstract Expressionism as a kind of 'iconoclastic fervor,' referring to the movement's ability to challenge traditional conventions of art making and to usher in new acceptance

and aesthetics that became an international movement. ${ }^{1}$ However, the historical tendency to categorize paired with the rise of the art critic, has created a limited view of the movement. As demonstrated in the thesis, Abstract Expressionism was far more varied than it is traditionally remembered. It is within the latter understanding that the thesis situates the work of Sally Hazelet Drummond. As implied by the remainder of the exhibition title, Sally Hazelet Drummond's journey to abstraction is another point of exploration in this inquiry. Drummond's art making started out figurative and then, after her introduction to Abstract Expressionism, became more abstract — and moved beyond the movement.

Chapter one covers the biography of the artist in order to illustrate her initial foray into and beyond Abstract Expressionism. Chapter two outlines a cursory explanation of 
Abstract Expressionism in order to provide the larger context within which Drummond is situated. Having briefly outlined the movement, chapter three places Drummond within the traditional understanding of Abstract Expressionism and demonstrates her departures and personal, artistic iconoclastic fervor. The final chapter elucidates the ways in which the thesis was demonstrated in the exhibition.

The thesis does not claim to be the final authority on Sally Hazelet Drummond nor is it a comprehensive exploration of Abstract Expressionism but it does contribute to the scholarship of the artist and advocates, in part, for further critical evaluation of Sally Hazelet Drummond and the other 'underknowns' of Abstract Expressionism. 


\section{CHAPTER I}

\section{ABOUT THE ARTIST: SALLY HAZELET DRUMMOND}

Since this thesis concentrates primarily on a single artist, it begins with a descriptive summary of her life and career. Many of the connections to Abstract Expressionism and the need asserted in this thesis to expand the understanding of Abstract Expressionism will be explained in this section. Later in the thesis these intimations and the implications for placing Sally Hazelet Drummond's work in an important position for art history of the period will be fully developed. Subsequent sections will include the voices of contemporary artists and scholars but this segment relies primarily on the voice of the artist as found in various statements, publications and artist's papers in order to get as close to the source as possible in the recounting of her life and art.

As a final note, Sally Hazelet Drummond prefers to be referred to by her full name; however, for the ease of the reader, her name has been abbreviated in this thesis to 'Drummond.'

\section{EARLY LIFE}

Sally Hazelet Drummond was born in 1924 in Evanston, Illinois, the daughter of Craig and Frances Hazelet. Craig Hazelet worked as a civil engineer and Frances was a stay-at-home mother. ${ }^{2}$ Drummond was the Hazelet's second daughter; Sue Hazelet, Drummond's sister, was two years her senior. ${ }^{3}$ Her parents were raised in Winnetka, Illinois which was then a suburb of Chicago and they returned to Winnetka shortly after 
Drummond was born. ${ }^{4}$ When Sally Hazelet Drummond was sixteen, the family moved to Libertyville, Illinois at the request of Frances Hazelet, who wanted to move to the countryside. Drummond went to New Trier High School. ${ }^{5}$ According to Drummond, "In high school there was a little art there in the background, but nothing terribly major. I took art. I guess I kind of took art. I never felt that I had any particular talent.",6

Drummond mentioned that she did not recall any real creative urge growing up but that an appreciation for the arts was instilled in her at a very young age. ${ }^{7}$ Drummond has written and spoken very little about her mother but mentions that her mother was interested in the arts. ${ }^{8}$ Drummond recalled that she would take her daughters to the Chicago Symphony, the Art Institute and the theater fairly often. ${ }^{9}$ Drummond says that her mother "didn't know very much about painting" but that she was 'artistic., 10 However, it appears that her mother did have expectations for her daughter; Drummond recalls a story in which Frances would critique her daughter's lack of practice during graduate school stating "You say you want to be a painter, why don’t you paint?" Drummond later states that she was apprehensive to paint due to a desire to 'find her own voice' instead of imitating others. The artist indicates that by the time she got to New York after graduating from the University of Louisville, she was painting regularly. ${ }^{11}$

The Drummonds moved to Louisville in the early 1950s. Craig Drummond, the artist's son, muses that it was likely Frances's interest in the arts that led Craig Hazelet to be involved. It is largely unknown to what extent Craig patronized the arts prior to his involvement in Louisville, Kentucky in the early 1950s but during and after Drummond's time at the University of Louisville, he served on the board of the Speed Art Museum. ${ }^{12}$ 
Furthermore, Drummond cites his support, both financial and emotional throughout her career. While Drummond asserts that the support was not always enthusiastic and describes their relationship as not 'terribly' close, she credits him with much of her success. ${ }^{13}$ In addition to the continued involvement with the Speed Art Museum in Louisville, Kentucky, Hazelet was also fundamental in keeping the Tanager Gallery operational through bankrolling many of its expenses in the last half of the gallery's run. ${ }^{14}$ Hazelet's support of Drummond's work and career was instrumental in her ability to become a professional artist at a time when few women were breaking such barriers.

\section{COLLEGE EDUCATION}

Upon her graduation from high school in 1942, Drummond enrolled in Rollins College, a liberal arts school in Winter Park, Florida. In a draft for a speech given at the school in 1989, Drummond mentioned that she did not have a clear idea of what she wanted to study but that it was during her time there that she took her first formal art class in sculpture. Constance Ortmayer, whom the artist describes as being 'saintly' in her instruction, taught the course. Drummond cites this course as fostering a deep interest in the arts for her but as an experience that was not without its frustrations. Drummond spent two years at Rollins College before "the idea of living in New York City had taken hold of her." 15

Drummond's first memory of New York is of a trip with her family at the age of nine. She mentions that "I was never so thrilled by anything in my young life, and I never forgot it." ${ }^{16}$ Her parents however were less enthused by her proposal to leave Rollins College for New York City and instead convinced her to move to Washington, D.C. 
where her sister, Sue, and her brother-in-law were stationed nearby in Fort Belvoir, Virginia. In 1944, in the midst of World War II, Sally Hazelet Drummond enrolled in the King-Smith School. Drummond's art education at this time included another class in sculpture. ${ }^{17}$ Unabated in her desire to go to New York, Drummond moved to the city.

Craig Hazelet disapproved of most of the art schools in New York but agreed upon Columbia University. ${ }^{18}$ Drummond attended Columbia from 1945-1948 where she studied painting and graduated with a bachelors of science. ${ }^{19}$ Drummond had wanted to study both sculpture and painting but the programs were mutually exclusive. ${ }^{20}$ At Columbia, Drummond studied under John Heliker, whom she cites as introducing her to progressive artists: Paul Klee and Merce Cunningham and writers: John Cage, Rainer Maria Rilke, Gerard Manley Hopkins and Franz Kafka. In an anecdote about Heliker, Drummond accounts positing "What's so great about Paul Klee. I just don't get it." to which Heliker responded, “Don’t worry about it, but just keep looking.” Evidently, the advice worked, as she cites Klee as an inspiration in her journey to abstraction. Drummond also mentions a student teacher, Eleanor Heuser, who introduced her to Edvard Munch, whose work she describes as "emotional and direct." ${ }^{21}$ Heliker's introduction of avant-gardism and the existential work of Munch both have direct ties to the abstract expressionists.

Drummond also took advantage of the New York scene to further her education. The artist herself says that "living in New York was as much of an influence on my development as a painter as my university study." Drummond mentioned going to the theater, foreign films, and modern dance and having seen Martha Graham, Merce 
Cunningham and Jose Limon. The art student also explored the collections of the Metropolitan Museum of Art, the Whitney Museum, the Brooklyn Museum of Art and the galleries along $57^{\text {th }}$ Street. $57^{\text {th }}$ Street was where first generation abstract expressionists were exhibiting. The mixture of historical and contemporary influences is telling in that her once self-described 'parochial and conservative' taste were increasingly becoming modern. ${ }^{22}$

Drummond's work at this time was figural. However, she never favored realistic figuration; the artist recounts being impatient with having to learn perspective, rendering and life-drawing. Drummond later regrets her haste but mentions that at the time, she was primarily concerned with discovering her own 'voice.' It was during her time at Columbia that she first describes feeling as if she had reached "a small plateau." She describes in particular a series of paintings inspired by the work of Edvard Munch and Gian-Carlo Menotti's opera, "The Medium." She describes the series as "slightly distorted interiors with one or two slightly haunted figures." While the artist later says that the paintings were not 'good,' a phrase reminiscent of the abstract expressionist critic Clement Greenberg, but that this marked a crystalizing moment in that it was the first time that she felt that the series was stylistically her own. ${ }^{23}$

After graduating from Columbia, Drummond returned to the Midwest in order to attend the Institute of Design in Chicago from 1949-1950. Founded by Bauhaus instructor and artist Moholy-Nagy, the school was conceived as another Bauhaus experiment, drawing on the emphasis of cross-disciplinary instruction in design, craft and fine arts. While Drummond has not explicitly stated why she decided to attend the school, 
it is likely due in part to her desire throughout her undergraduate career to be able to study multiple disciplines within and outside of the arts. ${ }^{24}$ Moholy-Nagy reiterates this principal in a 1937 statement about the school that Drummond included in her master's thesis: "There is an urgent necessity to create a collaboration between the different topics, to restore the basic unity of all human experience which could restore balance to our lives. ${ }^{25}$ Drummond studied at the Institute of Design for a year and a half. However, the Bauhaus-inspired environment must not have appealed to the artist, who cites that the school was "quite a shift away from the world of Edvaard [sic] Munch" and divulges that she continued to paint independently from her work at the institute. ${ }^{26}$ Drummond does however credit her studies at the school as having influenced her desire to exploit the flat picture plane and to further reduce forms. ${ }^{27}$ Moreover, the Bauhaus aesthetic is likely responsible in part for her constant desire to simplify her forms.

Drummond later recounts that her influences included a myriad of sources, including Paul Klee, Robert Motherwell, Pablo Picasso, and two teachers from the Institute of Design — Hugo Weber and Emerson Woelffler. ${ }^{28}$ The influence of Picasso is especially intriguing due to the association of Cubism to Abstract Expressionism. Hugo Weber was the head of the foundation course at the Institute of Design and would have been known by Drummond. Weber was an abstract expressionist and was friends with Franz Kline, Willem De Kooning and Jackson Pollock. ${ }^{29}$ Weber's work was gestural abstraction. In her master's thesis, Drummond cites Weber at length, demonstrating her affinity to abstract expressionism. ${ }^{30}$ Robert Motherwell, another first-generation abstract expressionist is an interesting inclusion to her list of influences in that his art was a subverted form of Abstract Expressionism. While Motherwell adhered to many tenets of 
conventional, Greenbergian, Abstract Expressionism, including the heavy use of black and white colorations, Motherwell also deviated from the traditional model, especially in his use of collage. ${ }^{31}$ The artist left the Institute of Design without graduating but articulates a strong desire to find her own style, "in my enthusiasm for the forms created by others and a reluctance to risk failure of forms of my own creation a resultant synthenticity [sic] marked most of my work at this time.,32

\section{GRADUATE WORK}

In 1950, Drummond started graduate school at the University of Louisville in Louisville, Kentucky where she graduated in 1952 with a master's of arts, having studied painting. Drummond attended the University of Louisville because her parents were living in the area. Edward Melcarth and Ulfert Wilke were her instructors. Wilke was on sabbatical the first year of her study but she cites his instruction and art as being highly influential. Drummond credits Wilke with introducing her to "contemporary American artists working mostly in New York," most especially the work of abstract expressionist Willem De Kooning. ${ }^{33}$

In addition to introducing her to the work of De Kooning and other abstract expressionist, Wilke also influenced her style and methodology. Wilke taught at the University of Louisville from 1948-1962 and although a German ex-pat, he can perhaps be described as a West-Coast abstract expressionist in terms of his interest in calligraphy and connection to Mark Tobey. Born in Bavaria, Wilke was highly influenced by the Neue Sachlichkeit movement who believed that their role was to act as "observers for a new age. ${ }^{\prime 34}$ Wilke's art can best be described as calligraphic and its influence can be seen 
in Drummond's early art of the 1950's in its largely conservative color palate, all-over patterning and bold, calligraphic strokes. Drummond describes Wilke as German, enthusiastic and as having been a 'compleat artist.' She still, as of July 2015, describes him as a talented painter and a significant influence. At this time, Drummond worked with lacquer paint - a medium that was introduced to her by Wilke, purportedly, because it dried fast. ${ }^{35}$ The switch from oil to lacquer paint is significant in that it indicates her desire to work quickly, a precept of the conventional 'gestural' style of Abstract Expressionism. Also significant in the correlation with abstract expressionists and the influence of Wilke is the way that Drummond worked during this time, what she describes as a "semi-automatic" manner without preparatory sketches that emphasized “accidental occurrence and simultaneity.",36

While Drummond describes her choice to enroll at the University of Louisville as more of a matter of convenience than an affinity to the program or instructors, her graduate work was largely an exploration into the new avant-garde style of Abstract Expressionism. ${ }^{37}$ When Drummond began the program, she was painting figuratively. In her graduate thesis, the artist shares an anecdote that outlines her earlier preference for figurative work; recalling a 1947 visit to the Whitney Museum, the artist describes the museum's "propensity of non-objective paintings and abstractions and a paucity of the illustrative." ${ }^{38}$ Drummond continues to write that her personal preference was with illustrative artists such as Edward Hopper. In outlining the then current debate between abstract versus realistic art, Drummond asserts that

The prevailing opinions were that art that rejected the appearance of nature in favor of personally invented forms although important as 
formalistic experiments did not constitute a total work of art. It was argued that the non-objective artists had retreated into an area where the vital connections between man and the universe had been severed. ${ }^{39}$

Further demonstrating her allegiance to figurative work, Drummond writes "I can not help feeling that when the artist ceases to think even in terms of known recognizable objects that his finished canvases represent merely a conversation between himself...period." Drummond goes on to state that abstract, what she called nonobjective, art was "terribly uninteresting." ${ }^{40}$ However, under the influence of Wilke, previously mentioned teachers and increased exposure to abstract expressionist ideology, Drummond's work began to embody core principles of Abstract Expressionism.

As can be seen in her 1952 master's thesis, "A Commentary on My Painting," Drummond's art experienced a major shift. Drummond describes her work upon entering the university to be figurative, "all very slapdash and expressionistic." The artist's description ties back to the influence of Edvard Munch-- whose art could fit into the same categorization. In particular, Drummond describes one of the exhibited works, Magician from 1951 (Figure 3), in that "everything was distorted, but figurative." ${ }^{\text {"41 }}$ Her thesis continues to trace her increasing abstraction and she attributes one particular defining experience; while painting a still life that had become too dark, the artist began to add white to the surface to lighten the tone. As she added the white paint, "the actual process grew so great that I was tempted to follow the process to the ultimate conclusion-a pure white canvas." Stopping just short of a solid white canvas, small areas of the previous picture remained. Following this path, Drummond's finished canvases at this time became largely white canvases - showing heavy evidence of the painterly gesture with small hints of forms, what the artist called "activated areas" that reveal an "undergrowth 
of labyrinthine forms." Untitled, from c. 1952 (Figure 4) is an example of the work she was creating upon her graduation. Tellingly, Drummond's thesis also describes her increased color palette that shifted from a heavy use of reds, ochres and blacks to an added use of greens and blues but admits that her final works are still largely monochromatic. Drummond stated that the use of too many colors "would have upset the already precarious balance existing between the images and their environment." ${ }^{, 2}$ Later her mature work would return to this interest in a more colorful palette.

\section{POST GRADUATE WORK: ITALY AND THE TANAGER GALLERY}

Upon Wilke's suggestion, Drummond applied for and received a Fulbright Grant. From 1952-1953 she studied in Venice, Italy. ${ }^{43}$ Writing about her time in Italy, Drummond states “the influence of my work after a year's residence in Italy cannot be obviously noted. However, I know that the opportunity to live among some of the greatest architecture, sculpture and painting of the western world, art which proclaims and reflects man at his noblest, lifted and sharpened my aesthetic standards." But whether attributable to the influence of her study in Italy or not, Drummond does state that her work at the time was becoming "more and more non-objective." Drummond describes the experience as 'sobering' in the sense that it provided a rich art historical context. Specifically, the artist recalls enjoying the Uffizi and that "there was something about Renaissance Florence. However, she also sought contemporary art and recalls that she bought one painting in Italy from Alberto Burri, whose work she had seen at the Venice

Biennale. She recalls that it was expensive, $\$ 100$ in 1953 , and that it was a sort of collage created out of burlap that was sewn and painted, about 3 feet square. Drummond mentions that the Fulbright was significant in that it provided her with credentials, "It 
gave you a great deal of freedom. It was a marvelous thing of tact and respect.” While traveling on a ferry in Italy, Drummond met an artist whom she had known at Columbia, Charles Cajori. Cajori, one of the founding members of the Tanager Gallery, suggested that Drummond bring her portfolio to the co-operative with the prospect that she may be invited to join the gallery. ${ }^{44}$

In 1953 after her Fulbright, Drummond again moved back to New York and showed her work to the artists at the Tanager. She became a member the same year, in 1953. The Tanager Gallery and the $10^{\text {th }}$ Street Co-Ops will be discussed further but Drummond's description of the gallery is worth quoting here:

I could go on and on about the Tanager Gallery but let me just say that from 1952-1962 it showed the work of over two hundred young and old artists most of whom were without an uptown gallery and all of whom we felt deserved a space in which their work could be viewed by the public. We made very few sales, but the critics came, the artists came and the general public came and quite a few of the artists established themselves uptown in good galleries and had successful careers. Three that you all may have heard of were Bill King, Philip Pearlstein and Alex Katz andoh yes, Tom Wesselman.

When Drummond joined the gallery, her work followed the conventional abstract expressionistic formula that she developed during her graduate work at the University of Louisville. These works were created quickly and relied on spontaneity with lacquer paint, so that the colors would not run together. They were painted on gessoed masonite panels. According to the artist, these works were "very abstract" but that her art was already showing a degree of simplification. Drummond says that she gradually began making 'empty canvases.' Next, she started regularly adopting the square canvas format and then added 'a heaviness in the center." In making these, Drummond used a four-inch 
sable brush and painted with thinned lacquer. The resulting product had a high shine. Art critic Paul Brach once commented that he could comb his hair in the reflection in her paintings. ${ }^{45}$

Drummond has talked extensively about the environment at the time. She specifically mentions Jackson Pollock, Franz Kline, De Kooning, Rothko, Philip Guston and Ad Reinhardt as being omnipotent figures whose work was highly influential to second-generation abstract expressionists. Drummond also mentions that "there was a real sense of community." However, Drummond's interest in these omnipotent figures came with preferences; Drummond notes that "De Kooning to me is abstract expressionism, and I find him so exciting and real. And he was the only one.... Kline I liked but not like I liked De Kooning. And I was influenced by De Kooning, although he'd probably never see it." ${ }^{\text {,46 }}$

In 1954 Drummond indicates being influenced by the work of Philip Guston and Ad Reinhardt. Her description of their influence and the impact of their styles on her own art are quoted here:

Guston was painting those lovely lyrical abstract paintings which are reminiscent of late Monets and seemed to generally link up with the French Impressionists in terms of color, paint quality and brush strokes. I also liked the fact that he emphatically placed the image in the center of the canvas. Ad Reinhardt was a different matter. He was ruthless in eliminating almost all physical, tactile, engratiating [sic] means available to the artist. He was the dark monk of the New York art scene. When he went into his studio he seemed to get rid of almost everything. ... in a sense you could say he fasted. His paintings were low keyed, austere, spare and ungiving. They were a sermon on restraint. Seen from a distance they appeared to be monochromatic but when one drew near one could see rectangles of slightly different value. After the bacchanalian orgy of paint 
throwing, dripping and splashing that went on in some quarters of the Lower East Side of New York, Reinhardt's astringent, restrained canvases were at times a welcome relief. I admired his multiple means of saying 'no' to so much. There was such an abundance of paintings that never rose above the level of mere ego-dripping extravaganzas.

The contrast of Guston and Reinhardt's work to the conventional 'gestural' style of Abstract Expressionism was significant for the artist. As intimated in the aforementioned quote, Drummond's art became 'simpler.' Drummond maintains that they "continued to be abstract and expressionistic but the number of forms became fewer and fewer." Whereas the artist's previous methodology, pioneered during graduate school, was a means of creating an undergrowth of images which were then painted over leaving only glimpses of 'activated areas,' Drummond's art continued to increasingly paint out the lines and colors until the artist was left with a "plain but agitated surface." Drummond had ventured into 'color-field' Abstract Expressionism. ${ }^{47}$

Gradually, the monochromatic canvas gained a simple form, a central core that was created by darkening the pigmentation at the center of the canvas. The canvases themselves also took on a new format, the square. Drummond continued in this vein, but expressed being 'unsatisfied' with the result until she explored pointillism. In 1958 the Museum of Modern Art exhibited a retrospective of post-impressionist pointillist Georges Seurat. The artist mentions in particular three sketches for Les Poseuses of female figures that she "hung around.... Like a moth around a flame." After the exhibition, Drummond began experimenting with pointillism. Her first forays into the technique produced larger dots widely spaced whereas the mature style featured smaller points closely situated. Increasingly, colors began to be applied liberally and the canvases were no longer monochromatic. ${ }^{48}$ 
The early works of this oeuvre had dark centers, like their color-field

predecessors. Drummond indicated that she felt that the core needed to have weight, "that the center needed to be weighted down." At the suggestion of a fellow Tanager member, Lois Dodd, Drummond experimented with shifting to a light center and was pleased with the result. Ruminating on the shift, Drummond states "it gradually became, not a matter of anchoring but of searching for a kind of radiance. ${ }^{, 49}$ Canvases remained square, a balance to the circular starburst-like center but varied in size ranging from modest 24 "x24" canvases to grander $60 " \mathrm{x} 60 " .50$ The largest of these however were still modest in comparison to the wall-sized works of typical Abstract Expressionism. By the time that the Tanager Gallery closed its doors in 1962, Drummond had developed the style she would continue to make until she stopped painting in the early 2010 s.

Aside from her artistic evolution, this time period marked significant life changes for the artist. Drummond got married to F. Weichel Drummond, "Wick," in 1961 in Louisville. Sally Drummond met Wick in Louisville through a real estate endeavor. Wick was also creative: he studied piano at the University of Louisville, the Yale School of Music and Juilliard, taught piano, repaired Steinways and was interested in architecture and construction. ${ }^{51}$ However, Sally Hazelet Drummond states that Wick Drummond “didn't talk about [her art]" and that they had very few of her paintings hanging up in their home. After their marriage, Sally and Wick Drummond continued to live in $10^{\text {th }}$ Street in the apartment Sally had lived in since her arrival in New York in 1953. The apartment also served as Drummond's studio. Wick and Sally Drummond welcomed their first and only child, Craig Drummond in 1962 in New York City and continued to 
live on $10^{\text {th }}$ Street. When asked about how she managed being an artist while having a baby, Sally Drummond replied, “it wasn't easy." Shortly after Craig Drummond's birth, the Tanager closed its doors and the Drummonds moved to Ridgefield, Connecticut when Craig was nine months old. ${ }^{52}$

\section{POST-TANAGER CAREER}

After the close of the Tanager Gallery in 1962, the artist gained representation by the Green Gallery and the Fischbach Gallery respectively. Richard Bellamy, an active art dealer in Abstract Expressionism, was the director of another $10^{\text {th }}$ Street artists' co-op, the Hansa Gallery. ${ }^{53}$ Bellamy was familiar with the Tanager Gallery and its artists and invited Drummond to join a new gallery he had founded, the Green Gallery. The Green Gallery operated until 1965 and exhibited Drummond's work in a solo exhibition in March 1962. The invitation to join the Green Gallery was in itself significant as the move marked a shift from the 'downtown' art scene - the $10^{\text {th }}$ Street artistic community to the 'uptown' art market, an 'uptown' gallery held the connotation of more prestige, and, as a result, more sales. It was a mark of success as the uptown galleries only represented 'established' artists. Additionally, Drummond's 1962 solo show would have been significant not only in terms of exposure, but also in part, as a feminist statement for Bellamy as women at the time were rarely shown independently. While the Green Gallery closed in 1965 only having been active there for three years, her affiliation with Bellamy and the gallery still had significant implications for her career. Drummond's work from the gallery was selected, along with that of Oldenburg and Rosenquist, to be included in Americans 1963 at the Museum of Modern Art. ${ }^{54}$ Next, Drummond was represented by the Fischbach Gallery. Drummond had solo exhibitions at the Fischbach 
in 1968,1972 and 1978 respectively. ${ }^{55}$ This time period also marked significant opportunities and exhibitions for the artist. Drummond's solo and group shows can be seen in her extended curriculum vitae in the appendices of this thesis.

Drummond was granted a Guggenheim Fellowship and lived with her family in France from 1967-68. ${ }^{56}$ Drummond was one of 294 grantees selected out of a pool of 2,006 applicants. ${ }^{57}$ Given the choice between a lump sum payment or a year paid for in France for her and her family, Drummond elected to move her family to the South of France. While Drummond recollects that the experience was difficult to set up-- finding "a place to live and paint and raise a family." The Drummonds settled into a 500 year old stone house with a separate room for her studio in Lacoste, France. While Drummond has written little about her time there, she does state that the environment was "divine" and that "she painted. ${ }^{" 58}$ In a later statement made in 1989, Drummond relayed that for her, "It's all color and light now, so no matter where I bounce in terms of living, it doesn't matter."59

Following her Guggenheim Fellowship, Drummond was given a retrospective at the Corcoran Gallery of Art in 1972. Gene Baro, then director of the Corcoran Gallery of Art, selected Drummond for the honor as a result of her exemplary "contemporary color abstraction[s]. ${ }^{, 60}$ Baro likely held the retrospective of Sally's work due to the city's corollary style, the Washington Color Painters. ${ }^{61}$ Sally Hazelet Drummond A Retrospective traced her work from 1958-1972, covering only the period after her pointillist technique was pioneered. Drummond's artist statement from the catalogue however reveals many of her earlier exploration and even paraphrases lines from her 
1957 text a "World of Silent Painting" from the September 1957 issue of Arts in Louisville Magazine:

I believe that all great art is an attempt to reveal the structural, infinite and beautiful order that lies deep within all existence. I believe it is this concern which binds together all the highest forms of art down through the ages. My vision is of a painting that declares this sensed reality in the purest and simplest terms. The total painting as the image --- silent, emphatic, radiant. ${ }^{62}$

Incidentally, the exhibition was highly covered in the press but not for the art. In a rather uncharacteristic course of action given the decorum of gallery openings, the Corcoran's chief executive, Vincent Melzac, and the Gallery's director, Gene Baro, engaged in a physical altercation in Drummond's gallery over who should be photographed with the artist. ${ }^{63}$ Nonetheless, the retrospective gave Drummond exposure in her own right; art critic Hilton Kramer reviewed her work in The New York Times. ${ }^{64}$

However even with the exposure of the Corcoran retrospective, Drummond's next major solo show was not until 1984 when she was shown at Artists Space in New York. Drummond's exhibition here was largely due to her connections with art critic Irving Sandler, who knew her from his time as the manager of the Tanager Gallery from 1956$1959 .^{65}$ Sandler was one of the founders of Artists Space, a non-profit gallery that exhibited work "that is new and unseen." However, this exhibition was a bit of a departure from the typical exhibition programming that promoted young artists in that Sally Hazelet Drummond: Paintings, 1971-1984 was part of a pilot series intended to "present three exhibitions by mature, mid-career artists whose work has not received extensive public exposure." While this exhibition and its curatorial premise will be 
discussed later, a brief section of the included artist's statement, reprinted from "The '60's in Abstract: 13 Statements and an Essay' in Art in America, is worth quoting here as it is evocative of the core of her work and a major thrust in this thesis: "My work has been about the concept of oneness - everything being connected, no foreground, no background, no separations, like a humming, a drone, emanating from somewhere, a unified field, pulsating, energetic.."66

In 1989 Drummond had a solo exhibition at Rollins College's Cornell Fine Arts Museum, the college she had attended briefly in the early forties. The show, like all of her previous solo exhibitions, celebrated her art after having discovered pointillism in 1958 but only exhibited works recent to the date of the show. In an interview with a reporter for the Orlando Sentinel, Drummond reflected that her work there demonstrates her search for 'the ideal' and that each painting represents a refinement, a modicum of progress towards what may well be an unattainable goal. ${ }^{67} \mathrm{~A}$ gallery talk given in conjunction with this exhibition was included in the exhibition catalogue and its full version is cited throughout this thesis and was therefore an instrumental resource. ${ }^{68}$ Around this time in her personal life, Drummond relocated from Ridgefield, Connecticut to Germantown, New York where she still lives as of this publication date. ${ }^{69}$

Only a year later, Drummond had another solo exhibition at another significant city in her life, Louisville, Kentucky. John Begley curated her 1990 show as the director of the Louisville Visual Art Association that was held at its gallery in the Louisville Free Public Library's main branch on York Street. Again, this solo exhibition concentrated on a narrow range of her current work, that from 1980-1990. The purpose of this exhibition 
as stated in the exhibition announcement was "an opportunity for Louisville to become reacquainted with her most recent concerns as an artist." ${ }^{, 70}$

Aside from the exhibition curated in conjunction with this thesis project, the only other solo exhibitions that the artist had in this century were by her commercial galleries. In 2003 the Mitchell Algus Gallery presented Sally Hazelet Drummond Paintings: 19602001. The press release for this show describes the artist "as a woman artist whose meditative rigor stood in opposition to the gnawing machismo of Abstract Expressionism"-- a similar line of inquiry to this thesis. ${ }^{71}$ Alexandre Gallery, her current gallery, curated a solo exhibition of her work Sally Hazelet Drummond: Selected Paintings in 2005. In following with the theme of all of the aforementioned solo exhibitions, Sally Hazelet Drummond: Selected Paintings only showed her art post-1958 and focused on the work as a contemplation of the "infinite. ${ }^{, 72}$

While this section has focused primarily on her solo exhibitions, Drummond had several significant group exhibitions and is in several significant collections that can be seen in her curriculum vitae included as an addendum in this text. However, it is imperative to note here the dearth of an inquiry into her earliest work. While many of the aforementioned solo exhibitions touch on her association with Abstract Expressionism and mention her underrepresentation as a significant artist, this exhibition and thesis proposes the position that her movement through and beyond Abstract Expressionism is crucial to the development of her mature work. It posits that Abstract Expressionism is an ideology as well as a historical art movement—one that was crucial to her developing her understanding and vision. Drummond's evolution goes beyond the original boundaries of 
Abstract Expressionism into a method of working that prefigures many important developments in the latter $20^{\text {th }}$ century. 


\section{CHAPTER II}

\section{ABSTRACT EXPRESSIONISM: A MOVEMENT, AN IDEOLOGY}

Unlike the previous section that focused exclusively on the artist at the center of this thesis, Sally Hazelet Drummond, this section provides a contextualization of the art movement she is positioned within, Abstract Expressionism. These accounts included below rely primarily on the words of art critics and art historians discussing the movement — most especially Clement Greenberg, the most famous of the art critics of the time, and Irving Sandler. This thesis relies heavily on Sandler's writings for several reasons. Chiefly, he was a contemporary of the abstract expressionists and lived and worked on $10^{\text {th }}$ Street. The majority of his texts included direct quotes from the artists or recollections of his personal encounters. Moreover, in contrast to many of the other contemporary writers, Sandler has continued writing and publishing volumes on the movement, including, most recently, American Vanguards: Graham, Davis, Gorky, De Kooning, and their circle, 1927-1942, published in 2011.

While there were derivatives of the style that occurred internationally, including, significantly, West Coast Abstract Expressionism, this thesis will concentrate primarily on New York Abstract Expressionism since that is where Drummond did the majority of her art making in the movement. Within the text, Abstract Expressionism and all derivatives thereof are to be understood to refer to New York Abstract Expressionism. 


\section{CHRONOLOGY OF THE MOVEMENT}

Abstract Expressionism is an art movement that flourished between 1945-1962. For the purpose of this text, the date 1945 used for the start of the movement. Although some scholars trace the movement back to the early 1940s, the middle of the decade and later is when most of the abstract expressionist pioneered their 'breakthrough' styles. One of the first uses of the term Abstract Expressionism occurred in 1946 in the New Yorker by Robert Coates. ${ }^{73}$ Art critic and historian Irving Sandler in his 1970 text The Triumph of American Painting: A History of Abstract Expressionism dates the movement from 1942 to 1952 which he states is based on a "close analysis of the works of fifteen artists. ${ }^{, 74}$ However, as Sandler himself has stated later, the canon needs to be revisited as the movement is far more varied than it has typically been remembered. ${ }^{75}$ Moreover, in the same text, Sandler remarks that it was not until 1947 that "Abstract Expressionists began to arrive at independent, mature styles that could no longer be subsumed under existing categories." ${ }^{, 76}$ Applying his later logic, the work of abstract expressionists prior to 1945, such as Jackson Pollock, Willem De Kooning, William Baziotes and Arshile Gorky, really belong to the latter styles of surrealism. Those seeking the earliest date for the beginnings of the movement can trace it to Wassily Kandinsky's improvisational paintings of the 1910s but the application would be largely anachronistic.

The end date for the movement is easier to trace. 1962 marks the close of the $10^{\text {th }}$ Street artists Co-Ops. Moreover, Clement Greenberg wrote his essay "After Abstract Expressionism" in the same year. In his essay reflecting on the movement titled "America Takes the Lead, 1945-1962" states that "In the spring of 1962, there came a sudden 
collapse, market-wise and publicity-wise, of Abstract Expressionism as a collective manifestation." ${ }^{, 77}$ Sandler has also commented on the significance of this date in stating that 1962 marked the year that The Club, a group of mostly male abstract expressionists artists who met weekly to discuss art theory, closed as well as the $10^{\text {th }}$ Street artists' CoOps. $^{78}$

\section{THE UNWANTED TITLE}

The title of the movement now known as Abstract Expressionism was a hotly debated topic. Abstract expressionists were a closely-knit community. Artists within the movement met often, most notably, in two formalized clubs known as 'The Club' and 'Studio 35.' It is as these meetings that some of the most fervent discussions of the title, Abstract Expressionism took place. In a series of panel discussions held at The Club in 1952 organized by P.G. Pavia, the artmakers and their critics resisted the use of any term insisting that they art they were making did not consist of any singular movement or style. ${ }^{79}$ In elucidating this sentiment in a 1950 meeting at Studio 35, Willem De Kooning stated that "it is disastrous to name ourselves. ${ }^{" 80}$ Mark Rothko, after being described in a review by Elaine De Kooning as an 'action painter' remarked that "to classify is to embalm.."81

Further information can be found in P.G. Pavia's essay "The Unwanted Title: Abstract Expressionism." Pavia organized the original discussions on the moniker at the club and ruminates on the general dissatisfaction with the categorization among the panels and audiences; at one meeting in 1952 Ad Reinhardt, a member of the panel, forbade the use of the term entirely ${ }^{82}$ Reinhardt was not the only one to reject the term. 
Even in his writings as late as 1962, Greenberg referred to Abstract Expressionism only in quotations. ${ }^{83}$

Art writers created and tended to use their own terminologies. Writing in 1964 Greenberg stated the he preferred to call Abstract Expressionism 'painterly abstraction.' ${ }^{\text {, }}$ However, earlier in the movement, Greenberg also used the term 'American-Type Painting. ${ }^{85}$ Harold Rosenberg coined the term 'American Action Painters. ${ }^{86}$ However it is perhaps E.C. Goosen, writing in 1961 that best summarized the phenomenon of naming the movement when he quipped "Abstract-Expressionism ... might well have been called 'Abstract Individualism.',"87

\section{THE ORIGINS OF ABSTRACT EXPRESSIONISM}

Abstract Expressionism is a movement that synthesized preceding art historical styles, psychologies and philosophies. As implied in the movement's namesake, Abstract Expressionism is affiliated with German Expressionism but the movement also takes a cue from Cubism and Surrealism. Created during World War II, this marked a period of virtual isolation for European artists who were shuttered by the war. As a result, without contact, the movement is largely an American phenomenon; the forced separation from the European art scene permitted American artists greater freedom to explore and push the boundaries of artmaking. Abstract Expressionism was a product of this increased

freedom and the influence of popular movements, philosophies and psychologies. ${ }^{88}$

Abstract Expressionism's association with German Expressionism owes much to the artists within the movement who worked in Germany after World War I. One of the 
foremost of these painters was Wassily Kandinsky. Interestingly, contemporary artists and writers within Abstract Expressionism attempted to sever the connection with the German artistic movement, most likely due to the strained relationship politically at the time between the United States and the German States from World War II through reunification. In the introduction to the foundational abstract expressionist exhibition, The New American Painting, 1959 at the Museum of Modern Art, director Alfred Barr maintained that abstract expressionist artists "rightly reject any significant association with German Expressionism.. ${ }^{, 89}$ However, French critic Michel Seuphor expressed dissenting opinion in his 1957 Dictionary of Abstract Painting that those believing Abstract Expressionism to have been created ex nihilo "have forgotten about Kandinsky: no more is needed than a visit to the Solomon R. Guggenheim Museum and see a dozen canvases painted by Kandinsky between 1912 and 1918, to grasp the fact that Abstract Expressionism was and is .... European, since it was born in Munich. ${ }^{, 90}$ Kandinsky, a Russian artist, is considered to be a member of German Expressionism due to his time painting and exhibiting in Germany. Kandinsky was by no means the only German Expressionist, however he is considered a principal founder of the movement.

Like Abstract Expressionism, German Expressionism encompassed a large number of stylistically diverse artists who all worked towards creating an art that reflected modernity in the aftermath of World War I and emphasized intense personal expression. German expressionists "turned to boldly simplified or distorted forms and exaggerated, sometimes clashing colors. Directness, frankness and a desire to startle the viewer characterize Expressionism in its various branches and permutations. ${ }^{.91}$ From the 
emphasis on personal expression to distorted forms and high use of color, the connection to Abstract Expressionism is clear.

Abstract Expressionism's affiliation with Cubism is less debated. As late as 1959 Greenberg, still refusing to accept the title cites that "a good deal of what is so rashly called 'Abstract-Expressionism' amounts essentially to a kind of Late Cubism.",92 Cubism, best known by the work of Pablo Picasso and Georges Braque is a style based on geometric planes and compressed space that thwarted traditional notions of perspective and representation. Cubist works challenged viewers by its distorted subject matter and laid the foundation for Abstract Expressionism in the presentation of what was often a highly abstracted, wholly unrecognizable final image. The Late Cubism that Greenberg refers to could be more accurately described as Analytical Cubism and was the most abstracted of the style and therefore, the closest visually to the work of the abstract expressionists. Greenberg was sympathetic to Cubism due to his belief that the style supported the flattening of the pictorial surface that for Greenberg, was a main tenet of Abstract Expressionism. ${ }^{93}$

Surrealism is the closest style to the time that Abstract Expressionism appeared and was connected to the first generation of Abstract Expressionists who were influenced by European ex patriots who congregated in New York in the thirties. Surrealism can perhaps best be described as an art of angst; formed in the aftermath of the First World War, the movement was artistic, literary and intellectual. Rejecting much of the rational thought of modern society, surrealist sought inspiration from the subconscious mind. ${ }^{94}$ Surrealist artists, such as Salvador Dali, Max Ernst, Joan Miro and Yves Tanguy relied 
heavily on automatism to tap into the unconscious. Similar to Freudian Free Association, the artist was encouraged to empty their mind of all preconceived ideas, knowledge and rationality and approach the canvas in a passive, receptive state. After laying down random marks, lines or doodles, the artist would then form images from the original visual cues. This technique of automatism was important for the abstract expressionist in that emphasized the importance of the unconscious and intuition as a means of expression. ${ }^{95}$

However, Sandler articulates the break from Surrealism as the emphasis that abstract expressionists placed on decision-making;

the gesture painters rejected the Surrealist notion that the unconscious was a reservoir of images possessed of the profoundest truths about man, and that when such images were revealed - and they could only be disclosed accidentally - they divulged meaning automatically and infallibly. The gesture painters refused to accept free-associational images without first submitting them to the process of willed action, which implied a struggle to choose. They attempted to make compulsive choices... but chance did not ultimately count for much, for the artist himself chose to accept, reject, or modify them. ${ }^{96}$

Ultimately, Surrealism led early abstract expressionists to return to 'primitivism', a charged term but one that refers loosely to the art made by societies "less civilized," often non-western, than the personages looking to them as a source of inspiration. Thus, themes drawn from early mythologies, cultures and world religions were employed as inspirations, subject matters and titles. ${ }^{97}$

Aside from the Freudian psychology tied into Surrealism, abstract expressionists also looked to existentialist philosophy as a source of inspiration. Spanning both the $19^{\text {th }}$ 
and $20^{\text {th }}$ centuries, Soren Kierkegaard, Friedrich Nietzche, Jean-Paul Sarte, and Simone de Beauvoir are all considered existentialist philosophers. As the aforementioned list of philosophers implies, existentialism is a varied branch of philosophy but is one that loosely deals with the nature of the human condition. Existentialism covered themes within the exploration of the human condition such as anxiety, freedom, situatednesswhich relied on the importance of context, irrationality, relationships, and, as the name implies, existence. German Expressionists also employed existentialism and read fellow compatriot, Nietzche, intensely. In the United States, abstract expressionists were more closely aligned with Jean-Paul Sarte, who had a lecture tour in the country in $1946 .{ }^{98}$

In Triumph of American Painting, Sandler mused on the association of Abstract Expressionism with existentialism and stated that artists "found the Existentialist conception of freedom more to their liking than Surrealist automatism, which seemed too permissive to them... Existentialism was attractive because it denied the idea that man has a definable nature, and because it emphasized his central role in determining his own existence." ${ }^{99}$ Still recovering from the horror of World War II, the line of questioning in existentialism provided solace for abstract expressionists while also encouraging their experimentation, individualism and iconoclastic spirit as will be described later.

\section{GESTURE AND COLOR: THE STYLISTIC TENDENCIES OF ABSTRACT EXPRESSIONISM}

As implied by the general dissatisfaction of the title, Abstract Expressionism, by artists and writers within the movement, there were a multiplicity of styles being created under the movement. However, it is generally accepted that Abstract Expressionism 
includes two main tendencies: 'gestural' and 'color-field' that fit under the larger header and are united in the sense that both iterations are 'abstract' and 'expressionistic' to some degree. Abstract, like the Cubist precedent, implied that the work was not a realistic depiction of the subject matter, if there was one, and, on the extreme end of the term, that there was no recognizable subject in the image, often termed 'nonobjective,' i.e. 'no object.' Expressionism, related to German Expressionism, held the implication that the work was painted to evoke emotions but the tone of those emotional responses varied widely. Gestural Abstract Expressionism and Color-Field Abstract Expressionism are both situated within this ideology. Sandler marks the bifurcating line as having occurred around 1949 when it became apparent that there were two main trends in Abstract Expressionism. ${ }^{100}$

\section{Gestural Abstract Expression preceded Color-Field Abstract Expressionism} chronologically and was more widely discussed by critics and writers. Gestural abstract expressionists "emphasized the improvisational touch or hand of the artist precisely because they wanted to call attention to the artist's individual creative process." ${ }^{.101}$ Improvisation is a key word implying the spontaneity of the creative process that harkens back to Surrealist's Automatism. Gestural abstract expressionists rarely worked from sketches, preferring instead to approach the canvas directly. The gestural touch, or 'hand of the artist' to use Sandler's description could be seen in the form of paint dripping, or more accurately, pouring, as in the case of Jackson Pollock or through the use of heavy impasto or visible application of paint and brushstroke, as in the work of Willem De Kooning. 
Color-field abstract expressionists relied on color for expression and suppressed the gesture of the artist in favor of controlled directionality and application of the medium. Sandler describes color-field painters as applying highly saturated colors in large expanses in order to create art that hinted at the sublime and suggested transcendence. This effect was generated in part by the juxtaposition of monumental sized canvases intended to be displayed in confined spaces in order to create an environment of color. ${ }^{102}$ Artists within this style in their desire to convey a sense of spirituality, were largely responsible for the convention of large scaled works in Abstract Expressionism that will be discussed shortly. Color-field abstract expressionists included the work of Mark Rothko and Helen Frankenthaler among others.

\section{THE GENERATIONS OF ABSTRACT EXPRESSIONISM}

Abstract Expressionism is often split chronologically into two segments: First and Second Generation. First-generation abstract expressionists include the group whose mature style was reached by the late-forties. These artists experienced the Depression and many were employed in the New Deal as part of the Federal Art Project that lasted from 1935-1943. Often dictated by popular taste, many of these works were illustrational in nature, deriving from '1930s Realism' and adorned public spaces. ${ }^{103}$ First-generation abstract expressionists faced the brunt of initial rejection and criticism and paved the way for the increasing acceptance of the succeeding generation and later styles. ${ }^{104}$ Criticism came from sources both within and from outside of the art establishment. In 1949 on the floor of the House of Representatives, Congressman Dondero decried "Modern Art is Communistic because it is distorted and ugly, because it does not glorify our beautiful country.... In plain, simple terms that everyone can understand. [It] breeds 
dissatisfaction. It is therefore opposed to our government, and those who create it and promote it are our enemies." 105 President Harry Truman considered contemporary art to be "the vaporings of half-baked lazy people," a description that was widely covered in the press. ${ }^{106}$

Within the artistic community, favor for Abstract Expressionism was also scant. Francis Henry Taylor, the director of the Metropolitan Museum of Art described abstract expressionists as "a flat-chested pelican, strutting upon the intellectual wastelands and beaches, content to take whatever nourishment he can from his own too meager breast" as opposed to the previous artists who were equated to soaring eagles. ${ }^{107}$ John Canaday, the New York Times art critic appointed in 1959, called abstract expressionists "cheats, freaks, charlatans, greedy lackeys, and senseless dupes." ${ }^{\text {"108 }}$ However, by 1959, Clement Greenberg's praise for the movement held far greater sway for readers. By the arrival of the second-generation abstract expressionists, first-generation artists were largely established along $57^{\text {th }}$ Street and in other uptown art galleries signifying their acceptance by the art establishment. ${ }^{109}$

The second-generation of Abstract Expressionism is generally traced to 1950 when artists, influenced by the work of first-generation abstract expressionists began to congregate along $10^{\text {th }}$ Street. These artists organized in the area between $8^{\text {th }}$ Street and $12^{\text {th }}$ Street that came to be known collectively as " $10^{\text {th }}$ Street" because of the low rent. Many were students of Hans Hofmann who established a school on nearby $8^{\text {th }}$ Street while others formed artists' co-ops. ${ }^{110}$ 
The importance of these artists' co-ops cannot be understated as they contributed both to the cultural atmosphere and the artistic community of $10^{\text {th }}$ Street. Most of the artists' co-ops were created by second-generation abstract expressionists who believed that their work merited exhibition but who could not get representation in the uptown galleries showing the work of first-generation abstract expressionists. Thus, these artists formed galleries along $10^{\text {th }}$ Street in the same neighborhood where other artists and sympathizers lived and worked. It was the members of the galleries who financed and managed the spaces that ultimately invited non-members, artists who they felt deserved to be shown, to exhibit. Exhibitions were a means for these artists of gaining credibility and legitimizing their professional standing but they rarely made money for the artists they exhibited or the members of the galleries that hosted them-which ultimately is what contributed to their closures. Like their first-generation predecessors, most the second-generation abstract expressionists contented themselves in living in near poverty in their pursuit for artistic freedom within their artistic community of $10^{\text {th }}$ Street. ${ }^{111}$

Many second-generation abstract expressionists were viewed negatively by critics and artists alike who, aligned with the first-generation, saw the latter's art as being derivative and unoriginal. Greenberg was especially hostile to the second-generation, calling their work that of the "Tenth Street Touch" which he described as a "blight" in which the movement had "degenerated" However within the same text, Greenberg acknowledges their status as abstract expressionists "A good part of the reaction against Abstract Expressionism is, as I've already suggested, a continuation of it."112 Allan Kaprow also disparaged the second-generation artists stating that the movement had become 'academicized,' no longer avant-garde, "a tremendous amount of dullness in 
abstract expressionism and impressionism: $10^{\text {th }}$ Street for example. ${ }^{113}$ However, instead of the negative stigma the second-generation abstract expressionist have received, some critics and artists, such as Irving Sandler, who were sympathetic, considered this generation's task to expand the work of the first-generation. ${ }^{114}$

\section{ABSTRACT EXPRESSIONISM AND THE RISE OF THE ART CRITIC}

The rise of Abstract Expressionism as a movement parallels the rise of the phenomenon of the art critic. While art criticism has a long history prior to the movement, the writings of art critics pertaining to Abstract Expressionism marked the first time that the opinions of art critics were sought out and listened to by the artists, the art establishment and the general public. As mentioned previously, the term Abstract Expressionism was used in 1946 by Robert Coates, an art critic.

Chief among these critics was Clement Greenberg, who was the first to exalt the movement and champion artists such as Jackson Pollock and Willem De Kooning, but other important writers included Harold Rosenberg, Thomas Hess, Barbara Rose and Irving Sandler. In the 1993 text Modernism in Dispute: Art Since the Forties, Wood, Frascina, Harris and Harrison, in talking about the culture of art criticism in abstract expressionism, state: "While it is true that Greenberg was not the only critic actively involved in examining and influencing the work of the Abstract Expressionists during the 1940s and 1950s, it would be difficult to claim that his role was not the most

important. ${ }^{\not 15}$ Irving Sandler, another art critic also acknowledges Greenberg's status in stating that his writings were more closely read and respected than those by any other 
critic. ${ }^{116}$ As a result, Greenberg's accounts of the movement are largely responsible for the historical understanding, albeit greatly limited, of Abstract Expressionism.

Clement Greenberg was a formalist, meaning that he primarily took his cues from the formal qualities of the art in question - the lines, colors, shapes and textures, rather than artists' statements or the relationship to other art historical styles. However, Greenbergian Formalism was limited, as Irving Sandler has discussed; Sandler, in criticizing Greenberg, described his dependence on formalism that was largely ineffable: "Greenberg argued that the main function of criticism was separating good art from bad, yet he believed that there could be no criteria for judgment, it being ultimately a matter of taste. ${ }^{117}$

Greenberg did not solely rely on formalism alone, he also attempted to give credence to the movement by anchoring it within art history. Greenberg placed Abstract Expressionism within an art historical context. In "Avant-Garde and Kitsch" he asserts "it has been in search of the absolute that the avant-garde has arrived at 'abstract' or 'nonobjective art.'” In the same essay, Greenberg traces the abstract expressionist emphasis on materiality in contrast to earlier modernists such as Picasso and Kandinsky. However, the use of the term 'nonobjective' is problematic when applied to abstract expressionists in the sense that there were artists belonging to the cannon of the movement that worked in representation. Greenberg later acknowledges representational art, especially De Kooning's "Women" series by stating that this search for representational art was a means of creating depth in the picture plane, "a more coherent illusion of three-dimensional space." ${ }^{118}$ 
As indicated previously, due to Gestural Abstract Expressionism's precedence,

Greenbergian conventions for the gestural style are far more common.

Greenberg’s seminal 1955 essay “'American-Type’ Painting” is worth quoting for its revelatory nature of many of the 'tenets' of abstract expressionism:

Many of the abstract expressionists have at times drained the color from their pictures and worked in black, white and gray alone. Gorky was the first of them to do so, in paintings like The Diary of a Seducer of 1945 - which happens to be, in my opinion, his masterpiece. But it was left to Franz Kline, who first show was in 1951 , to work with black and white exclusively in a succession of canvases with blank white grounds bearing a single large calligraphic image in black. That these pictures were big was no cause for surprise: the abstract expressionists were being compelled to do huge canvases by the fact that they had increasingly renounced an illusion of depth within which they could develop pictorial incident without crowding; the flattening surfaces of their canvases compelled them to move along the picture plane laterally and seek in its sheer physical size the space necessary for the telling of their kind of pictorial story. ${ }^{119}$

While the quote in this case refers primarily to the gestural style, its emphasis is revealing. Greenberg touts the importance of the refined color palette-primarily the use of black, white and tan, the use of the gesture and flatness. In one of Greenberg's earliest reviews of Willem De Kooning, he praises the artist almost exclusively for his use of black, gray, tan and white. ${ }^{120}$ The flattening of the canvas is another emphasis of Greenberg's review and one that has roots in Cubism. Greenberg describes Kline's use of gesture as calligraphic, but he has expanded on the concept in other texts. In "Hans Hofmann: Grand Old Rebel" Greenberg goes on to discuss gestural paintings in stating that "open calligraphy and 'free' shapes that rule in 'Abstract-Expressionism.,",121 Writing at the close of the movement in 1962 Greenberg states "If the label 'Abstract 
Expressionism' means anything, it means painterliness: loose, rapid handling, or the look of it; masses that blotted and fused instead of shapes that stayed distinct; large and conspicuous rhythms; broken color; uneven saturations or densities of paint, exhibited brush, knife or finger marks." ${ }^{122}$ This quote and the extended quotation previously mentioned also demonstrate the influence of color-field Abstract Expressionism in the use of monumental scale and widening of palette, which demonstrates the closeness, overlapping and interdependence of the two styles.

Greenberg talks about color-field abstraction specifically in two major articles, "Louis and Noland" from 1960 and "After Abstract Expressionism" from 1962. In "Louis and Noland" he describes the Color-Field abstract expressionist's departure from Cubism, and, by default, the gestural abstract expressionists, in that "Cubism meant shapes, and shapes meant armatures of light and dark. Color meant areas and zones, and the interpenetration of these, which could be achieved better by variations of hue than by variations of value." Greenberg expands on the color-field technique of pouring washes by stating that such work "conveys a sense not only of color as somehow disembodied, and therefore more purely optical, but also of color as a thing that opens and expands the picture plane. ${ }^{, 123}$ Greenberg goes on to assert that the new style necessitates a large canvas. In his essay "After Abstract Expressionism," Greenberg explained the ColorField abstract expressionists' need to expand the size of the canvas due to the fact "more

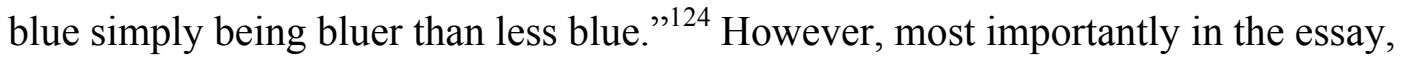
Greenberg asserts that the color-field abstract expressionists advanced painting beyond the work of Gestural Abstract Expressionism. ${ }^{125}$ 
Greenberg was notorious for promoting specific artists, thus limiting the cannon and contributing to the celebrity status for artists within his sphere of influence, most especially Jackson Pollock whose art Greenberg sponsored heavily. ${ }^{126}$ Moreover, Greenberg's popularity led his writings to become the doctrinaire about Abstract Expressionism. While not specifically referring to Greenberg, Anne Eden Gibson's description is fitting. Writing in 1997 Gibson describes the critics who wrote about the movement as having "established rather limited standards," ones that, while purportedly universal, were highly influenced by historical referents, politics, racism and, most important in this inquiry, sexism. ${ }^{127}$

\section{A LIMITED UNDERSTANDING OF THE MOVEMENT: TENETS AND MISCONCEPTIONS OF ABSTRACT EXPRESSIONISM}

\section{COLOR IN ABSTRACT EXPRESSIONISM}

One of the Greenbergian principles for Abstract Expressionism was a refined color palette. Greenberg, even after touting color-field painters, reinforces the abstract expressionist convention for eschewing color by stating in 1962 that "Abstract Expressionism has worked in the end to reduce the role of color." ${ }^{128}$ Early abstract expressionists working within the gestural style worked primarily in black, white and tan. Sandler postulates that, at least in the case of Willem De Kooning was due, in part, to the artist's inability to afford expensive oil paints. ${ }^{129}$ Whatever the justification, Greenberg praised De Kooning's refined color palette as previously mentioned and therefore solidified the stylistic preference for monochromatic palettes. However, the actual work of abstract expressionists employed a variety of colors. 


\section{MATERIALITY, FLATNESS AND DEPTH}

Another convention of Abstract Expressionism was an emphasis on materialitymeaning an exposure of the flatness of the canvas and of the dimensionality of the materials used. Deriving in part from Cubism, the belief was that the flatness of the canvas should be exploited instead of hidden through the accurate rendering of threedimensional objects, as had occurred throughout the history of art. Moreover, in his essay “After Abstract Expressionism," Greenberg praised the color-field abstract expressionists for showing the texture of the canvas through the watered-down washes of their medium. ${ }^{130}$ However, whether through sculptural build up of paint, or through the illusory use of dimensionality-- albeit flattened-- through figurative painting, depth was also part of Abstract Expressionism. An examination of the Pollock's "drip" paintings, with layers upon layers of thick paint subverts the conventional notion of the 'flat' canvas. Sandler has also commented on the depth of Abstract Expressionism through the example of De Kooning:

In one sense, gesture painting is reductive, but De Kooning achieved complexity by making each mark the bearer of a variety of meanings. One arc of the brush, for example, might suggest the contour of a shoulder, its volume and the space behind it, or the letter $\mathrm{C}$ as if scrawled on the sidewalk - and, when related to other brushmarks, its possible meanings become endless. ${ }^{131}$

Gestural abstract expressionists were not the only artists within the movement to exhibit depth in their paintings, color-field abstract expressionists also created depth within their works. Artists such as Sam Francis and, more well known, Mark Rothko, created color-field paintings with depth. Sam Francis' 1952 painting Blue-Black 
illustrates this concept; the foreground of the painting is covered in black brushstrokes with hints of the yellow, red and blue brush stokes of the underlying layers creating depth. Rothko's paintings, such as Number 20, from 1950, are typical of his horizontal bands of colors that overlap in sheer washes that act as veils to hint at the layers underneath. While flatness has long been understood as a tenet of Abstract Expressionism, depth — even within flatness, is also part of the movement.

\section{SPONTANEITY AND INTENTIONALITY}

Abstract Expressionism is conventionally understood as an art that relied on spontaneity. The materials are typically thought to have been laid down quickly, with the artist selecting the artistic merit of each mark-- keeping or rejecting the newest application. While there are artists who did work quickly, finishing a canvas in a single session, there are also abstract expressionists who worked slowly and deliberately. Elaine De Kooning, an abstract expressionists artist and art critic wrote about two artists, Hans Hofmann and Josef Albers who worked fervently. In her article on Josef Albers, Elaine De Kooning reports in the first sentence that the artist completed his painting in five hours. Elaine De Kooning elaborates further in her article on Hans Hoffman when she described the artist as "working with astonishing speed, never sitting down, constantly in motion between his palette and his easel, applying his paint with broad, lunging gestures, Hofmann often finishes a painting in a few hours." She goes on to quote him as having set the requirement that "A picture must be finished in one sweep."132

While spontaneity, a derivative of the automatism of Surrealists artists, was a mainstay of Abstract Expressionism, the technique did not require brash gestures as much 
as it required a degree of creativity and artistic expression that did not involve sketches and studies. As art critic Harold Rosenberg stated in his essay "The American Action Painters," a requirement for modern artists was that they did not work from sketches and approached the canvas without preconceptions of the final image. In recalling an encounter with an abstract expressionist artists, Rosenberg reports the response:

"B--- is not modern," one of the leaders of this mode said to me. "He works from sketches. That makes him Renaissance."

Here the principle, and the difference from the old painting, is made into a formula. A sketch is the preliminary form of an image the mind is trying to grasp. To work from sketches arouses the suspicion that the artists still regards the canvas as a place where the mind records its contents - rather than itself the "mind" through which the painter thinks by changing a surface with paint. ${ }^{133}$

While the standard for abstract expressionists may have been to work without sketching the image beforehand, there was no corollary time requirement and there were many artists, both gestural and color-Field who worked deliberately. Irving Sandler recounts a story of the working process of gestural abstract expressionist Willem De Kooning that illustrates both the expectations for abstract expressionists to work fervently and the artists' actual artmaking process.

In 1956, two friends and I made a film of de Kooning at work. We arrived at his studio late at night with our rented cameras, lights, etc., lugged them all up the three flights, set everything up laboriously, and then ordered him to paint. He had a marvelous picture in progress, and he painted on it in an "action" manner. Our camera followed his movements avidly, the flailing brush, the dancing feet. It couldn't be better as film. A few days later I met de Kooning on the street and asked how the painting was going. He said that he had junked it the moment we left. I asked why. "I lost it," he said. "I don't paint that way." Then why the charade? He answered, "You saw that chair in the back of the studio. Well, I spend most of my time sitting on it, studying the picture, and trying to figure out what to do next. You guys bring up all that equipment, what was I supposed to do, sit in a chair 
all night?" "But Bill," I said, "in the future, they'll look at our film and think that's how you painted." He laughed. ${ }^{134}$

De Kooning was not the only artist who worked against the convention of the feverish abstract expressionist; Mark Rothko, noted Color-Field abstract expressionist, also stressed the deliberateness of his process. ${ }^{135}$ While there are abstract expressionists who fit the stereotype, such as Hans Hofmann and Josef Albers, there is also a precedent for abstract expressionists such as De Kooning and Rothko who worked deliberately over time.

\section{SIZE AND THE PROBLEMATIZING OF THE ABSTRACT EXPRESSIONISTIC} MONUMENTAL SCALE

As stated previously, a staple of traditional Abstract Expressionism was the use of monumental scale. Elaine De Kooning, in talking about the movement stated that, with the exception of the large size of a painting, "there is no exclusive 'look' to Action Painting. ${ }^{136}$ However, even the convention of the large scale of Abstract Expressionism requires revision. Clement Greenberg's writings were critical in establishing the movement's association with size; Greenberg specified, "Abstract painting, being flat, needs a greater extension of the surface on which to develop its ideas than does the old three-dimensional easel painting." ${ }^{, 137}$ The critic's bias is evident in another essay even by its namesake, "The Crisis of the Easel Picture." In the essay, Greenberg states that art created on an easel scale is merely decoration, not art. ${ }^{138}$ As a result, many abstract expressionists attempted to fit the critics notion of monumental scale. In 1947 Jackson Pollock applied for a Guggenheim Fellowship in order to paint mural-sized paintings. Clyfford Still favored "the big picture;" Mark Rothko and Adolph Gottlieb asserted in the 
New York Times that their works were not made to fit over the mantle place. However, in talking about the scale of abstract expressionist's works, Sandler remarked that size was relative and that the art "on the whole were very rarely very large." 139

The most complete exploration of the smaller scale of Abstract Expressionism occurred from 1989-1990 in an exhibition organized by The Jane Voorhees Zimmerli Art Museum at Rutgers State University of New Jersey. Abstract Expressionism: Other Dimensions, An Introduction to Small Scale Painterly Abstraction in America, 1940-1965 traveled to the Lowe Art Museum, the Museum of American Art in Chicago and the Jane Voorhees Zimmerli Art Museum and published a comprehensive catalogue of the same name. The curatorial premise states

Abstract Expressionism: Other Dimensions was formulated as an experiment in visual art history; that is, the significance and validity of any insights it offers into American painterly abstraction are predicated on the evidence of the paintings themselves. Whether the small works by famous artists --- or the art of forgotten artists who preferred to paint small pictures - attain a memorable niche in the general perception of advanced abstract painting will depend very much on the willingness of individual observes to judge this art in an unbiased manner. ${ }^{140}$

The evidence in the exhibition was compelling. With a maximum size of 36 by 36 inches, the 146 exhibited works covered both well known and underknown abstract expressionists spanning a wide chronology and therefore covering several stages of their artists' careers and effectively combating the tenaciously held notion that abstract expressionistic art had to be large. In his catalogue essay, Jeffrey Wechsler states "of greatest interest to the topic at hand, though, is the fact that several major Abstract Expressionists created small works consistently throughout their careers and often did so 
in great numbers." Wechsler specifically mentions exhibited artists Robert Motherwell, Hans Hofmann, Jackson Pollock, Franz Kline, Willem de Kooning and Theodoros Stamos. In an included interview with Jeffrey Wechsler, Irving Sandler and Sam Hunter, the writers discuss the relationship of abstract expressionist artists, such as Charles Seliger who worked on smaller scales and their omission from the cannon of abstract expressionists. Sandler remarks that he knew Seliger and left him out of his text as a result of the pressures and conventions of scale imposed by other artists and critics. Sandler goes on to state that large size was often equated with 'major' painting. ${ }^{141}$ Ultimately, as the exhibition and catalogue demonstrated, the perception of Abstract Expressionism in relation to its linkage to large scale, when compared to the actual work of artists working within the movement requires a revised understanding of the movement.

\section{ABSTRACT EXPRESSIONISM AND THE RUGGED INDIVIDUALIST}

Abstract expressionists have often been viewed in popular culture as typifying the rugged individualist of American mythology as opposed to members of a dynamic artistic community. From the resistance of artists and writers to accept the stylistic term 'Abstract Expressionism' because they were too individualized to be grouped together under a single title to the depictions of abstract expressionists in popular culture, the artists and writers cultivated an image of the artists as unique, larger-than-life personalities. In a famous Life article on Jackson Pollock that was published August $8^{\text {th }}$, 1949 in which the artist is presented all alone in a dramatic full-color portrait wryly viewing the camera with arms folded and legs crossed. His head is cocked back and his cigarette is precariously balanced at the corner of his mouth in front of 'drip painting' 
Number Nine. Ann Eden Gibson has discussed this article and the larger concept of the artist as individualist in her text Abstract Expressionism: Other Politics. In the chapter "The Abstract Expressionist Hero," Gibson states "the photograph promised an exciting new version of the American painter: rugged, insolent, proletarian, inscru." Life again covered Pollock a decade later in November of 1959; the text in that issue editorialized Pollock's western roots and hard drinking. Gibson explains “Abstract Expressionism had come to stand for a certain kind of frontier heroism that supported the American ideals of universalism, individualism, and freedom." However, Pollock's public persona was a carefully cultivated image; Lee Krasner, Pollock's spouse, recalls a story in which she asked the artist where he kept his books. Pollock shows her a bookcase hidden in a closet. ${ }^{142}$ Pollock's image of a rugged individualist was carefully contrived. Life extended the individualist image of the abstract expressionists to artists other than Pollock. In a famous image titled "Irascible Group of Advanced Artists" published January $15^{\text {th }}, 1951$, shows Willem De Kooning, Adolph Gottlieb, Ad Reinhardt, Hedda Sterne, Richard Pousette-Dart, William Baziotes, Jackson Pollock, Clyfford Still, Robert Motherwell, Bradley Walker Tomlin, Theodoros Stamos, Jimmy Ernst, Barnett Newman, James Brooks and Mark Rothko as individual personas even among the group shot due to their closed body language and eyecontact. ${ }^{143}$ Moreover, in the previously quoted anecdote Sandler told about his experience filming Willem De Kooning, he describes the scene of the lone artist feverishly attacking the canvas in that it "couldn't be better as film.",144 Sandler was praising his success in capturing the careful cultivation of the abstract expressionist as individualist. 
Regardless of the popular image of the artists, the reality for the abstract expressionists was a strong sense of interaction, camaraderie and community. Abstract Expressionism, especially among second-generation practitioners, was a movement that, perhaps more than any preceding style is signified by its sense of community. Sandler, a contemporary of the abstract expressionists who lived and worked on $10^{\text {th }}$ Street has said:

The Abstract Expressionists in fact formed a loose community, meeting frequently in each other's studios and homes and in certain restaurants, bars and galleries. They followed each other's work closely, establishing what Robert Motherwell called an underlying network of awareness, in which everyone knew who was painting what and why. The Abstract Expressionists also shared an enthusiasm for modern ideas and a Romantic outlook on life. ${ }^{145}$

Rosenberg discusses the $10^{\text {th }}$ Street environment and in particular their relationship to community; "Tenth Street is the opposite of a community. No one willed it: its coming into being took everyone by surprised... Tenth Street is a tribe based on the rugged individualism of American pioneering - an impossible contradiction and therefore most likely to fit." ${ }^{146}$ Rosenberg's description of the contradiction of the 'community of individuals' highlights the experience of these artists. While they worked to maintain an image fitting the convention of the artist as individualist, these artists formed clubs and co-ops in formalized associations and lived, worked and exhibited together in their daily lives. Community and interaction, albeit of strong-willed artistic giants of the firstgeneration among their devoted second-generation followers, was part of the abstract expressionist experience. 


\section{MACHISMO AND VIOLENCE OR LYRICISM}

Closely tied to the persona of the abstract expressionist as rugged individualist is the machismo endemic in Abstract Expressionism. From the coverage of male artists, especially Pollock, in Life to the image in the same magazine of the 'Irascibles' featuring only one woman among a sea of male artists, Abstract Expressionism was presented in the media as being a male dominated field. Critics rarely wrote about abstract expressionists women. Clement Greenberg was particularly misogynistic. While Georgia O'Keeffe was not an abstract expressionist artist, Greenberg's review of an exhibition of her art reveals many of his chauvinistic undertones: "that an institution as influential as the Museum of Modern Art should dignify this arty manifestation with a large-scale exhibition is a bad sign."147 The exhibition in question was O'Keeffe's retrospective. Artists Lynda Benglis described Abstract Expressionism as a "macho, sexist game."148

While the environment for women abstract expressionists was hostile in the mid1940 s to the early 1960 s, even modern scholars have displayed chauvinist thinking. Problematically, leading abstract expressionist scholar, Michael Leja, in his text, Reframing Abstract Expressionism: Subjectivity and Painting in the 1940s, writes that "nearly all the artists were male." Leja goes on to state that "Perhaps most revealing of the 'masculinity' apparently inherent in Abstract Expressionist art is the fact that so few women attempted to align themselves with it during the crucial formative years, the 1940s and early 1950s." ${ }^{149}$ The statement is grossly inaccurate. The machismo of the abstract expressionist scene in New York systematically barred women from participation and critical success. Anne Eden Gibson has taken a feminist art historical perspective to 
Abstract Expressionism successfully in her text Abstract Expressionism: Other Politics. In response, Irving Sandler, a male art critic retorted that she was "put off by the absence of women" but that "in the end, we must not forget... that Abstract Expressionism took place in another era. ${ }^{" 150}$ While the statement is true, it does not negate the feminist reevaluation of the cannon nor the experiences of women who tried to break down barriers in Abstract Expressionism.

Female abstract expressionists faced innumerable impediments from other artists, critics and the art establishment at large. Lee Kraser, reflecting on the environment states that 'It's quite clear that I didn't fit in, although I never felt I didn't. I was not accepted, let me put it this way ... with relation to the group, if you are going to call them a group, there was not room for a woman." Krasner's quote was not unfounded; Hans Hofmann, in referring to Krasner's work in 1937 quipped "this is so good you would not know it was done by a woman." Gibson situates the plight for women in Abstract Expressionism within the larger historical context of the 'women problem;' by positing "how did the national preoccupation with restoring women to their roles as wives, homemakers and mothers affect the critical and economic fortunes of such female artists as Ruth Abrams, Louise Bourgeois, Lee Krasner, Rose Piper and Hedda Sterne?" Here, the question is obviously rhetorical. Louise Bourgeois, in commenting on the dearth of female abstract expressionists in institutions such as the Museum of Modern Art stated that "People didn't know they existed. They were ignored." ${ }^{\prime 51}$

Perhaps even more dangerous than being a female artist was being accused of painting in a 'feminine style.' Sandler remarked that adjectives such as 'beautiful' or 
'elegant' were insults. ${ }^{152}$ However, it is important here to note that those descriptions have highly traditional, albeit sexist, feminine associations relating back to the expectation of women as decorative objects for male desire. During a 1950 meeting of abstract expressionists at Studio 35, Ad Reinhardt asked "Is there anyone here who considers himself a producer of beautiful objects?" No one answered in the affirmative. ${ }^{153}$ Thomas Hess, in his description of the art of Willem De Kooning remarked "The picture was no longer supposed to be Beautiful, but True — an accurate representation or equivalence of the artist's interior sensation and experience. If this meant that a painting had to look vulgar, battered, and clumsy—so much the better."154 Violence, even pictorial violence against woman, as in the case of De Kooning's mutilated female figures in his "Women" Series was the status quo.

However, Abstract Expressionism was full of art that was not in line with the violence and machismo of conventional Abstract Expressionism. Art of this type was prevalent enough that it was often called abstract-impressionism or lyrical abstraction. ${ }^{155}$ Elaine De Kooning even observed that “Abstract-Impressionists ... outnumber AbstractExpressionists two to one, but curiously, are seldom mentioned." ${ }^{\prime 156}$ Gibson, in quoting Hedda Sterne "recalls that a 'feminine' painting in the 1940s was one without strong contours, without sharp angles, and without points. It would be delicate, sensitive, and tentative." Gibson expands on the association in stating that "These 'feminine' characteristics in art corresponded to the social qualities expected of a 'good' woman: grace, sweetness, motherliness, and gentleness." ${ }^{\prime 157}$ While the historical bias against lyrical abstraction or abstract impressionism is not only due to inherent sexism; the 'feminine qualities' aforementioned also applied to works made by men, like Theodoros 
Stamos, William Baziotes, Philip Guston and Mark Rothko. Moreover, masculine terms and the 'violence' of Abstract Expressionism could also be applied to paintings made by women — explaining Hans Hofmann's judgment of Lee Krasner's art. ${ }^{158}$ Perhaps as a result of its association with 'femininity,' lyrical abstract expressionism, and the works of female abstract expressionists, have been discounted. Illustrative of this point is Greenberg's description of Mark Tobey's "delicate affair of pale tints" and the critic's assertion that "his painting is not major." "I59 In reflecting on the time, Sandler remarks that chauvinistic bias of the abstract expressionists "led, if inadvertently, to the marginalization of the lyrical paintings of male first-generation Abstract Expressionists such as Hans Hofmann, Bradley Walker Tomlin, James Brooks, Esteban Vicente, and Jack Tworkov, even though they were not pigeon-holed as feminine. Only well into the 1950s did they receive recognition along with leading second-generation women artists, such as Joan Mitchell, Grace Hartigan, and Helen Frankenthaler.”160

\section{SPIRITUALITY AND ABSTRACT EXPRESSIONISM}

Barnet Newman, in describing himself and other abstract expressionists stated that these artists "made cathedrals of ourselves."161 The statement exemplifies the individualist psychology of conventionally defined Abstract Expressionism. Critics reiterated the need to omit spirituality in art; Greenberg, writing in 1949 describes Abstract Expressionism as being "uninflated by illegitimate content—no religion or

mysticism or political certainties."162 The eschewing of religious qualities, or spirituality, often considered a feminine quality, was part of maintaining the images of the artist as a rugged, masculine individualist. 
However, spirituality was in fact a both a source of inspiration and a desired effect for abstract expressionists. Stephen Polcari in his text, Abstract Expressionism and the Modern Experience, has explored at length the role of religion and spirituality, albeit largely 'primitive' religious encounters, as being a key intellectual root for the movement. Polcari states that "Many Abstract Expressionists returned to origins as a step in the direction of the self-analysis, conservation and change in civilization." ${ }^{.163}$

For abstract expressionists, especially those of the color-field style, often sought to evoke spiritual qualities in the final images. Hans Hofmann, artists and teacher for many second-generation abstract expressionists "taught that painting at its highest should reveal spiritual reality." ${ }^{, 164}$ Artist and art writer Elaine De Kooning described Franz Kline and Mark Rothko as having arrived at their mature styles in a manner similar to the conversion of Saul of Tarsus. ${ }^{165}$ The analogy of the artists to a spiritual leader is telling. In another essay Elaine De Kooning elucidates “Abstract Expressionism was America's last great spiritual movement as it expressed itself in art. ${ }^{~} 166$ Artists, especially those of the color-field style attempted to incorporate spirituality, in a variety of forms, into their art; Newman began to use the terminology of "the sublime," Rothko sought "transcendental experience," and Still tried to evoke "exaltation." Art critics confirmed this phenomenon in essays such as Robert Rosenblum's "the Abstract Sublime" and Lawrence Alloway's "the American Sublime." ${ }^{, 67}$ While the terminology varies widely, spirituality, contrary to conventional notions of Abstract Expressionism, was part of the movement. 


\section{CHAPTER III}

\section{SALLY HAZELET DRUMMOND AS AN ABSTRACT EXPRESSIONIST}

This chapter relies on a synthesis of text written by and about Sally Hazelet Drummond in order to situate her within Abstract Expressionism in the early 1950's and delineate her departures from the traditional, Greenbergian, notions of the movement. It begins by tracing her roots within the movement, both in the gestural and the color-field style. Next, Drummond's departures from her early exploration with abstraction will be examined. Finally, the chapter highlights the artist's intentional change in working ideas and methods, and how both her process and her gender determine some of the inherent values that characterize Drummond's work and the barriers she faced. Ultimately, the section anchors her work with Abstract Expressionism and traces her departure from conventional tenets of the movement all while establishing the need for an expanded understanding of the movement.

\section{EXPLORATION INTO ABSTRACTION}

\section{TIES TO CONVENTIONAL ABSTRACT EXPRESSIONISM}

Drummond's work has been described as fitting into a myriad of styles ranging from minimalism ${ }^{168}$ to Abstract-Post-Impressionism ${ }^{169}$ to Op Art. ${ }^{170}$ The multiplicity of genres into which she has been assigned is indicative of the nature of her work, and to a larger extent, how varied Abstract Expressionism was as a style. However, her

participation on $10^{\text {th }}$ Street, her self identification and her inclusion in abstract expressionist exhibitions, such as Abstract Painting: 1960-1969 in 1983 at the P.S. 1 and 
Lyric Abstraction at the Whitney Museum of American Art in 1971, demonstrate her art as belonging to the general category of Abstract Expressionism. ${ }^{171}$

Abstract expressionist critics, Irving Sandler and Thomas Hess, have described Drummond's work in terms that encompass both gestural and color-field qualities. Writing a review of the Museum of Modern Art's Americans 1963, Thomas Hess described Drummond as having qualities that fit both gestural and color-field Abstract Expressionism; speaking of her art, Hess declared that she is "a dedicated purist, who works with one kind of color at a time and one kind of brush mark most of the time." While it is perhaps an exaggeration to say that Drummond works in one color at a time, her canvases do appear from a distance to have an overall color and only upon closer inspection can the plurality of colors be seen. Of critical note here is that Hess' discussion of her use of color, tying her to the color-field abstract expressionists who emphasized the primacy of color as the image. Hess also recognizes Drummond's beginnings within the gestural abstract expressionist group by describing her use of gesture, as a "one kind of brush mark." ${ }^{172}$ It is important here to note that her gestural marking is a highly controlled iteration of gestural Abstract Expressionism in comparison to much of the spontaneity of traditional gestural paintings. Irving Sandler, in the curatorial statement he wrote for her 1984 solo exhibition at Artists Space, describes her work as being both "coloristic and painterly," which identifies her within both the gestural and color-field styles. ${ }^{173}$ 


\section{AUTONOMOUS TECHNIQUE}

Drummond makes use of an autonomous, or semi-autonomous technique, a method employed by many abstract expressionists. As mentioned in the previous discussion of Abstract Expressionism, this technique derived from Surrealism and supported the notion of the artist's courting their unconscious or subconscious as method for achieving a transformative understanding of truth. While Drummond's art relied on automatism and spontaneity in the beginning of her journey to abstraction, her work after she created her pointillist style in 1958, which dramatically changed her working method, and the finished appearance of her work, still maintained some of the same principles. Drummond never worked from sketches and contemporary critics described her latter artmaking process as 'trance-like. ${ }^{174}$ In her 1952 thesis, Drummond asserted "Making preparatory sketches is not possible with my method of painting because the accidental occurrences and simultaneity that I seek cannot be transferred and even if there were a way to transfer them their inherent spontaneity would become synthetic." In the same text, describing spontaneity further, Drummond articulates "The spontaneity and freedom which characterizes so much of the work of the school of contemporary painters known as abstract expressionism and to which my present work shows an affinity, has to be the result of genuine controlled impulses. If spontaneity is forced by the will it becomes vague and aimless."

In an artist's statement from later in the same year, Drummond confirms her affiliation with other tenets of conventional abstract expressionist artistic processes, chiefly chance and direct process. In the statement, Drummond states 
In my recent paintings I have tried to express forms emerging in space, forms that have no particular beginning or ending but which are in a state of flux and change. Most of the forms appear as accidental occurrences. I do not consider these as mere designs but as statements that derive their authority from nature. Chance and accident are constantly at work in nature. They can result in great beauty. I try to recognize and to preserve those images that are meaningful and to reject those that are not.

I never make preparatory sketches, preferring to work from a semiautomatic beginning, directly on the board, building up the surface of the painting, and finally, to allow a few images to make their appearance. By reducing the number of forms to a minimum, I hope to gain a simplicity and directness of expression. ${ }^{176}$

The artist's emphasis on chance is important but it is also imperative to note that she clearly mediates this accidental start with her own artistic authority. She cites that her forms "appear as accidental occurrences" but that it is her volition as an artist that she selects which of these designs are kept and which are dismissed. Additionally, Drummond states that she does not work from preparatory sketches—-harkening back to Harold Rosenberg's statement of sketches not being a requirement for abstract expressionists. Moreover, the artist states that she works in a "semi-automatic" manner, symbolic of the abstract expressionists' borrowing of Surrealist automatism. However, the use of the qualifier semi- divorces the term from the full Surrealist's association of total reliance on the unconscious.

\section{NON-OBJECTIVE ART}

The most obvious manner by which Drummond is affiliated with Abstract Expressionism is her non-objective subject matter. While Drummond's early works, such as Girl Sitting, c. 1940s (Figure 1.), Girl in a Doorway, 1949 (Figure 2.) and Magician, 1951 (Figure 3.) are all figurative, Drummonds work after 1952 were non-objective, having no recognizable subject matter at all. 
The Oxford Dictionary of Art defines non-objective art as a "general term for abstract art that is intended to be completely non-representational, rather than derived (however remotely or obliquely) from appearances in the world around us; most commonly it is applied to severely geometrical works." ${ }^{, 177}$ The Tate Museum adds to this definition by stating that non-object art often "aims to convey a sense of simplicity and purity." ${ }^{, 178}$ Drummond's art created in the early 1950s was not geometric but her monochromatic paintings with central core as a compositional focus and later her pointillist technique with the application of equidistant dots to create the same central core imagery become increasingly geometric. Their reduction of shape into a single overall form comes to embody the simplicity and purity stated in the aforementioned definition. Hilton Kramer, reviewing her exhibition at the Fischbach Gallery in described her art as "rigorously nonobjective." ${ }^{179}$ While the adjective seems strange in describing art that is expressionistic, perhaps what Kramer was alluding to was the second half of the Tate's definition, that non-objective art "aims to convey a sense of simplicity and purity." The connotation of simplicity and purity became progressively more important to Drummond's art over the course of her career.

\section{FLATNESS}

Another convention of Abstract Expressionism is flatness; Drummond adopted a quality of flatness early in her career. In her 1952 master's thesis, Drummond stated: "The flatness of the canvas no longer defied me and I soon responded to its challenges to exploit the inherent flatness." ${ }^{" 180}$ Drummond's quote parallels many of Greenberg's writings about the topic. However, as discussed earlier, within the convention of flatness 
in traditional Abstract Expressionism is also the idea of great depth, often created through layers of paint. Drummond's monochromatic canvases and art after her pointillist conversion both fit within this description. Like the color-field painters Rothko and Frankenthaler, Drummond's monochromatic canvases, with their darkening center tones, were created through layers of washes and thus created a sense of depth even while emphasizing the materiality of the canvas and pigments. After she started using a pointillist technique in 1958, the depth implied through the painstakingly individually applied dots of colors she achieves is more akin to the drip-paintings of Jackson Pollock. Drummond's art can be compared to Rothko, Frankenthaler and Pollock, all charter members of the abstract expressionist cannon, whose work explored flatness, but also depth.

\section{GESTURE}

Drummond's early abstractions made use of the gestural style and fit into an abstract expressionist narrative. In Drummond's early works, such as Girl Sitting, c. 1940 (Figure 1.), Girl in a Doorway, 1949 (Figure 2.), and Magician, 1951 (Figure 3.) all demonstrate the presence of the gesture; brushstrokes are apparent on the surface. Untitled, dated c. 1952 (Figure 4.) is the most conventional gestural abstract expressionistic of these early paintings and also demonstrates the gesture of the artist in the form of thickly applied paint and evidence of the brushstroke. An excerpt of the artist's "World of Silent Painting," written in 1957 the year before she adopted her pointillist technique, describes her use of gesture: "The paint was applied in heavy strokes, thin strokes; it was alternatively dripped or daubed on the canvas depending on the intuitive impulse." ${ }^{181}$ Drummond's description of her gesture is directly connected to 
her interest in spontaneity, what she calls "intuitive impulse[s]." As discussed previously, spontaneity was a tenet of conventional Abstract Expressionism. While she would later renounce the "bacchanalian orgy of paint throwing, dripping and splashing," it is important to note her roots in gesture as a working method for creation. ${ }^{182}$

In 1958 Drummond started utilizing a pointillist technique. While the brush strokes matured into petite points, the application still resulted in a sculptural build-up of paint, somewhat related to the build up of paint achieved in her earlier work through gestural brush stokes, drips and daubs. Drummond describes her application of the dots

as "little touches." "183 The use of the word 'touch' is significant because it still implies the gesture of the artist.

\section{COLOR}

Drummond's art of the late 1950s also developed affinities that relate to what became known as color-field Abstract Expressionism. After the conventional gestural paintings such as Untitled, c. 1952 (Figure 4.), Drummond made monochromatic canvases with a darkening of tones in the center of the canvas. The works are similar to her current oeuvre but lacked what became her signature pointillist technique. While no works of this style are extant, the image has been reproduced in Figure 15, Blue Painting, 1957 and is an example of this re-introduction of color into her work. Referring to this series of her art, Drummond wrote a "World of Silent Painting" that was printed in Arts in Louisville Magazine in the September issue of 1957. An excerpt of that text quoted here explains its relationship to her and her work. It could also be read as a manifesto for color-field Abstract Expressionism: 
My present paintings each have a single color uninterrupted by line or shape. The color is laid on in a series of thin glazes restricted to subtle variations within the narrow limits of the dominating color. In the center of each painting is a concentration or deepening of tone, which serves as a focus or core of the painting....

For me, color is the basic ingredient of painting, and it is with color that I try to express my feelings. The outer form of my paintings is the rectangle of the canvas. The inner form is striven for through the depth and richness of the color. Cezanne said, "When the color is at its richest, the form is at its plenitude." My ultimate goal is to create a single radiant field of contemplation where form and content have become one. In 1908 Matisse said, "What I dream of is an art equilibrated, pure and calm, free of disturbing subject-matter, an art that for any intellectual worker, or business man or writer can be a means of soothing the soul, something like a comfortable armchair in which one can recover from physical fatigue. ${ }^{184}$

From the use of glazes to the description of a largely monochromatic canvas to the artist's description on the transcendent qualities of color, the art is firmly situated within color-field Abstract Expressionism.

Even after her adoption of the pointillist technique and widened color palette in 1958, descriptions of Drummond's work from critics, curators and the artist herself still anchor the art within the color-field style. Sarah Lansdell, an art critic in Louisville, Kentucky for The Courier Journal, described Drummond "as a painter who deals only with color." ${ }^{185}$ Again in Louisville, art critic Diane Heilenman is more explicit; for the artist's 1990 show at the Louisville Visual Art Association, she labeled Drummond "a noted color field painter." ${ }^{\prime 186}$ Art critic Dore Ashton described the artist's use of "color harmonies." ${ }^{187}$ For her retrospective at the Corcoran Gene Baro described, "Mrs. Drummond's paintings are at one with the best in contemporary color abstractionspiritually and technically. Their overallness, the management of color, the absence of 
shape, the subtle vibrancy and spatial amplitude are elements of a vision fully mature and achieved." 188 In one interview, Drummond even uses the term, "It's just one color field of, I would hope, a fusion." 189

\section{BEYOND ABSTRACT EXPRESSIONISM}

While Drummond's art has antecedents in both gestural and color-field styles, her art can be described as somewhere in between and beyond. The non-objective multicolored canvases are certainly fitting within the color-field style but the presence of the dots also ties the art to the gestural style. In his text The New York School, which featured Drummond, Sandler depicts Drummond's work as having "reduced color and gesture, ending up with near-monochromatic fields of subtly varied impasto." 190 The quotation indicates that Sandler sees Drummond as being associated with but not wholly proscribed to gestural or color-field styles. Tellingly, there were other terms, not popularized enough by critics and writers to be declared as individual styles, but prevalent enough to imply a number of artists who either fit in both or neither of the traditional categories of gestural and color-field styles. These terms, as discussed in the section "Machismo and Violence or Lyricism" included Abstract-Impressionism or Lyrical Abstraction.

While lyrical abstraction and abstract-impressionism are closely linked, lyrical abstraction connotes art that is more gestural but rejects the propensity for violence in the expressive mode; whereas Abstract-Impressionism, as implied by the title, is abstracted art that shows the influence of the impressionist school and thus emphasizes the effects of light. 
Drummond's work has attributes of both. She has cited the work of the impressionists' as a source of inspiration and has spoken about 'light' in her art; Drummond describes the effect of light in her art as having a "certain exuberance" or "radiance." ${ }^{, 191}$ Critics have also commented on the interplay and role of light in her art; Sandler described her art as "luminous" and in a draft for his text in Art News Lawrence Campbell wrote:

A single ray of sunlight starts on its journey. It passes through layers of heated gas. In due course it arrives at the atmosphere surrounding the earth. It has been reflected many times before it finally enters the room by a window. Then it strikes and is turned aside by what is to us the most significant part of its journey - the irregular surface of an object we are now looking at, a stretched, square canvas on the wall by Sally Hazelet Drummond. Its covering of small dots of paint recharges the ray of light which scatters before reaching the end of its journey in our eyes. We see a shimmering aureole of color, a luminous field, a vision, darkening slightly at the edges, and faint light in the center. ${ }^{192}$

While Campbell's language is theatrical, the association of Drummond's work with light and therefore, with abstract-impressionism is apparent.

Drummond's art also fits in the term 'lyrical abstraction.' Drummond cites Philip Guston, whom she describes as a lyrical abstract expressionist as a source of inspiration for her in the early $1950 \mathrm{~s} .{ }^{193}$ While the association does not directly make her art lyrical abstraction, it does demonstrate a connection for her with the values associated with the artists working in this manner. Moreover, abstract expressionist art critic Thomas Hess, in comparing her art to the work of Ad Reinhardt in Americans 1963, stated that she "brings in light where Reinhardt subtracts it and she has a lyrical quality while he broods. ${ }^{, 194}$ [emphasis added] Most convincing to the connection is Drummond's 
inclusion in the exhibition Lyrical Abstraction in $1971 .{ }^{195}$ Drummond's art fits into a multiplicity of categories within and outside of conventional understanding of Abstract Expressionism.

\section{THE BREAK FROM CONVENTIONAL ABSTRACT EXPRESSIONISM}

In her early work in an abstract expressionist vein, Drummond admits how much she admired De Kooning. As perhaps her first and foremost influence, her description of his art is telling "There was so much raw energy in DeKooning's canvases and that energy didn't stop at the edges... it was propelled beyond them. It was a kind of magnificent informed chaos that he dished out. And I too trotted along in his wake."196 The attitude of artistic freedom and iconoclasm characterized by De Kooning is likely responsible for inspiring her own iconoclastic fervor.

Largely describing works such as Untitled, c. 1952 (Figure 4.), by the time Drummond was creating her monochromatic canvases the artist says that she "gradually bit by bit... left the exuberant cacophonic world of abstract expressionism and entered a world of 'silent painting.", ${ }^{~} 197$ In expanding on her departure from conventional Abstract Expressionism to her own iteration, what she called "Silent Painting," Drummond articulates:

In the middle ' 50 s it became clear that in order to find my identity, I had to work my way out of Abstract Expressionism. The main thing that bothered me about Abstract Expressionism was that there was so much accident. A more classical attitude was growing in a path toward symmetry and harmony was replacing the exuberance and explosiveness that so moves me in the work of de Kooning. Two of the critical influences in those years were Ad Reinhardt and Philip Guston. What I liked about Reinhardt was his intellectual austerity, his ability to say no to 
so much that was going on around him. He was almost a counter-cultural voice in the mid-'50's. The main thing that appealed to me in Guston's paintings (which were abstract at the time) was their centering quality; the focus was in the center, like a target. I was also drawn to their tactile quality and sensuousness. Yet I felt he didn't finish his paintings, he didn't bring them out to the edges. ${ }^{198}$

Drummond objected to the dominance of gesture in much of Abstract Expressionism. Her increased interest in a 'classical attitude' of color-field painter Ad Reinhardt and the spiritual nature of the 'centering' approach of Guston marks changes in the development of her own personal style. Intriguingly, Philip Guston's art of the time still showed heavy paint application and therefore presence of the gesture, which Drummond intimates in reference to "their tactile quality." The aforementioned quote does indicate what Drummond is protesting to in conventional Abstract Expressionism, the 'accidental,' spontaneity of the work. In other words, Drummond states that she objected to the "bacchanalian orgy of paint throwing." 199 Drummond's monochromatic canvases and her turn to a distilled and quiet pointillist method mark a dramatic shift in her approach to making art. The result was what she referred to as 'simplification.'

\section{SIMPLIFICATION}

Drummond reiterates that her increased interest in simplification was in response to what she saw as a certain lack of discipline or rigor on the part of the artist, in particular, its reliance on spontaneity, or accidental gestures: "I painted in a very abstract expression style. But as I continued it, I subliminally was objecting, I guess, to all the accident. There's so much accident—Expressionism! And I became interested in seeing how much I could eliminate." ${ }^{200}$ Drummond's penchant for simplifying the lines and shapes can be traced even to her early art-- what can be considered conventional, abstract 
expressionist's works she created for her master's thesis at the University of Louisville. In her thesis, she demonstrates the refining of one canvas in which she increasingly painted and repainted the image until it resulted in only a few 'activated' areas. ${ }^{201}$

She came to see this break with the happenstantial use of gesture as in line with art history and what she saw in her trips to Europe. Drummond regarded the simplification of art as being rooted in art history; "To me the most significant impulse in the $20^{\text {th }}$ century has been the search for essentials, the need to simplify stemming from Cezanne, Seurat, later Brancusi. I think of myself as an illustrator. Nobody creates anything. We recreate and recombine what we perceive out there in nature." ${ }^{202}$ Even with her self-identified break from Abstract Expressionism into what she called "Silent Painting" Drummond still saw her art as belonging within the movement: "The paintings continued to be abstract and expressionistic but the number of forms became fewer and fewer."203 Drummond's simplification, her 'Silent Painting' in opposition to the conventional reliance on accident, emphasizes the deliberateness of the artistic process.

\section{PROCESS}

In contrast to the reliance on spontaneity and gestural, individualistic mark making, Drummond implemented a very deliberate artistic process that relied on discipline and her will or volition to make critical decisions about her art. Her use and volume of dots were discrete, separately applied decisions that required precision and attention to detail. By her own account, even though she painted daily, she only was completing two paintings a year. ${ }^{204}$ 
Art critics and writers have also commented on Drummond's technique. Gene Baro stated "the surface does not simply happen, an accident of the motility of paint. Instead, it is made, carefully built stroke by stroke to confer spatial freedom on the two dimensional surface. ${ }^{205}$ In emphasizing the deliberateness of the process, the Arts New England Newsletter reported "Drummond constructs entirely with brushwork-petitpoint dots of color-which means deliberation. ${ }^{206}$ Drummond's artistic process does more than counter the accidence and brash action of Abstract Expressionism, it presents a different, although not incompatible, alternative view of the movement.

\section{SCALE}

Similar to the deliberateness of her painting process, the use of monumental scale is typically understood as being a hallmark of the movement. However, as Abstract Expressionism: Other Dimensions demonstrated, modestly scaled paintings, those painted on an easel scale, were far more prevalent than conventionally understood. The largest known painting Drummond created is Connections, 1971 measuring 72" x 72" whereas the smallest work is Hummingbird, from 1961, measuring 12 " x $12 \frac{1}{8}$ " all of which are considered easel scale and are hardly the wall sized canvases of Pollock, Still, Rothko or Newman. ${ }^{207}$

Art writers have also discussed Drummond's scale and its implications. Martha B. Scott reported "In dimension Drummond's canvases range from small and medium to large but are always on a human scale... they span the space which can comfortably be encompassed by the mind's eye." ${ }^{208}$ Gene Baro, in writing the introduction for her retrospective at the Corcoran Gallery of Art describes her scale as "ambiguous" but 
proffers that "her work always offers a larger visual experience than its dimensions.,"209 Taking the implications for her scale even further, Hilton Kramer speculated that her "relative obscurity" was likely due at least in part to her scale: "she has continued to work in a relatively small format at a time when wall-size painting has - in more than one sense—caught the eye of the public. ${ }^{210}$ Although not unfounded, Drummond's use of easel scale challenges an accepted expectation of Abstract Expressionism and, according to Kramer, may be partially responsible for her 'relative obscurity.'

\section{COMMUNITY, SPIRITUALITY AND THE 'PAINTER LADY'}

\section{COMMUNITY}

In opposition to the individualistic psychology that enveloped much of Abstract Expressionism, Drummond described, "There was such an abundance of paintings that never rose above the level of mere ego-dripping extravaganzas." Drummond's art

embraced notions of interconnectivity. ${ }^{211}$ Drummond describes the individualist spirit of the movement in her text a "World of Silent Painting," "Abstract expressionism is an assertion in exaggerated and powerful terms of a world personally created by the artist." 'Personally created' implies an art movement that centers on the artist as individual. ${ }^{212}$ When asked if her painting was personal, Drummond responded with a definitive "no," she cites that the work is hers, but is not about her. ${ }^{213}$

As discussed earlier, the $10^{\text {th }}$ Street art scene in the 1950 s was a strong community. In describing her time with on $10^{\text {th }}$ Street, Drummond says, "It was a very dynamic period particularly for painting and there was a real sense of community."214 Sharon Corwin, in describing the members of the Tanager Gallery specifically wrote, 
"The supportive environment on $10^{\text {th }}$ Street allowed artists with a contrarian tendency to flourish.... This was a circle of colleagues and friends who banded together for intellectual, creative, and social exchange; they established a sense of community and believed that together they could make their lives as artists." ${ }^{215}$ Intriguingly here is the description of these artists as 'contrarian,' implying that these artists - the secondgeneration of painters inspired by the first-generation of abstract expressionists-- were breaking barriers and were therefore iconoclastic. Moreover, Corwin elucidates the camaraderie within the Tanager Gallery and notably this roster of artists, including Pearlstein, Katz and Dodd, generally did not follow a strict abstract expressionist path.

In addition to the sense of community in Abstract Expressionism and for Drummond's co-op in particular, the artwork also intrinsically relies on interconnectivity. In an artist's statement published in 1983 Drummond wrote: "My work has been about the concept of oneness - everything being connected, no foreground, no background, no separations, like a humming, a drone, emanating from somewhere, a unified field, pulsating, energetic." ${ }^{216}$ Additionally, in her 1989 gallery talk for her solo exhibition at Rollins College, Drummond states: "I like to think of my work as having something to do with connections. I like the concept of connections and I like it in life. When connections are made between things, individuals, families, communities, nations, planets... It gives me a lift... makes me feel good." ${ }^{217}$ The imagery, through the use of thousands of individual dots come together to create an image of radiance and expansion symbolic of the artistic community in which she matured and of her belief in the power of community and connections among viewers. 


\section{SPIRITUALITY}

Abstract Expressionism, especially the gestural branch of the movement, whether due to the individualist psychology or the atmosphere of machismo, often had a touch of inherent violence. From the clashing and muddying of colors to distorted subjects, such as in De Kooning's "Women" series, the art of the time was often aggressive. Drummond describes De Kooning's work as embodying "the virus of violence." In expanding on the artist's use of violence she describes:

When I look at this portrait of Marilyn Monroe and see what he did to this fragile quite lovely vulnerable woman I think of Beirut, or what we are doing to our environment... the rain forests of Brazil... the violence of neglect toward the poor, minorities; the violence of neglect to our children, the violence toward each other, to ourselves.... Tieneman Square in China... DeKooning seems like a man ahead of his times. ${ }^{218}$

Note the acceptance in this statement; it is not condemnation nor approval but very much in keeping with her spiritual roots in the 'oneness' of the statement aforementioned. In contrast to much of the violence of abstract expression Drummond worked to created an art that was peaceful, and even had spiritual qualities. In a 1957 interview with Louisville journalist Harry Shaw, Drummond stated "So much of the art of this century has been rebellious, negative. I am searching for something positive and permanent; tranquil and harmonious. ${ }^{219}$

Closely related to Drummond's views on community and interconnectivity is the artist's views on spirituality as are often manifested in the titles of her work. In an undated interview, Drummond describes the process of naming one of her works with a spiritual motif: "I read a seventh century Chinese Sutra which mentions 'Indra's Net.' It's 
a description of reality, the basic reality - the ground of being, if you will - as a network, and the corner of every segment is a jewel, that reflects every other jewel. And I called one of my paintings, immodestly, 'Indra's Net.' I like to think that everything is connected - that 'God notices every sparrow's fall." ${ }^{220}$ Other examples of spiritual or community-focused titles include Connections, 1971, No Separation, 1991 (Figure 12.) and New Born, 2004. ${ }^{221}$

Drummond has also made direct statements about spirituality in her art from from monochromatic paintings to date. In 1957 in the text a "World of Silent Painting," Drummond stated "I am trying to affirm something that I believe - that underneath all the complexities and contradictions in nature there is a silent, pure, and eternal presence and force. ${ }^{, 22}$ Her theme of a higher presence continued into the sixties after she pioneered her pointillist style. In her artist's statement for The Private Myth, 1961 at the Tanager Gallery, Drummond wrote:

I believe there exists within the complex of nature one pure undifferentiated power. It is eternal and creates expanding form out of inert matter, gives direction to undisciplined energy. I feel that if this spirit is sought intensely enough and with enough concentrated devotion, form will eventually present itself.

My vision is of an art that declares this sensed reality in the purest and simplest terms - the total painting as the image — silent, emphatic and radiant. $^{223}$

In another text written by the artist ca. 1965, Drummond reveals her belief in the position of her art to reveal spirituality: 
I believe that all great art is an attempt on the part of the artist to express his faith in the unseen, but intuitively felt structured and infinite beauty lying inherent in the visible world. This faith and concern, I believe, is what binds together all the highest forms of artistic expressions of man down through the ages.

I believe there exists within the complex of nature, one pure undifferentiated power. It is eternal and creates expanding form out of inert matter, gives direction to undisciplined energy.

My vision is of an art that declares this sensed reality in the purest and simplest terms - the total painting as the image — silent, emphatic and radiant. $^{224}$

The artist's desire for the viewer of her paintings to feel "warmed, refreshed and at peace," borrows spiritual terminology. ${ }^{225}$ Most recently, in an interview conducted in 2015 , the artist stated that her art has "a spiritual quality to it." 226

Related to the spirituality also invoked by key color-field painters as mentioned in Chapter II, Drummond's position on the power of her art to evoke higher powers or suggest the infinite is, while contrary to some of the individualist psychology and machismo often connected to Abstract Expressionism, in keeping with other powerful strains within the movement.

\section{'PAINTER LADY'}

Abstract Expressionism was largely male-dominated and highly chauvinistic.

Drummond states that she was largely unaware of her sex and its effect on her success as a painter; "I was interested in painting and the fact that I was a woman never occurred to me. ${ }^{, 227}$ However, when asked by Erik La Prade about women in the arts in the 1950s and 1960s, Drummond responded: “I don’t think there were a lot of women. Abstract 
Expressionist [sic], which was reigning high at that point, was pretty much a male school." Drummond goes on to declare that she was "not particularly a feminist" but concedes that she did and still does have sympathy for women. ${ }^{228}$

However, in discussing the specifics of her time on $10^{\text {th }}$ Street, Drummond mentioned many aspects of discrimination. Writing to Cindy Nemser about discrimination of women in the arts, Drummond stated that she was not acutely aware of sexism but did acknowledge that the idiosyncratic, personal and highly individualistic nature of artists would have made such assessments difficult to determine and therefore was often subverted and masked. Tellingly however, Drummond signs her response to Nemser as "Painter Lady," a title that intimately associates her profession to her gender. ${ }^{229}$ In talking about her time with Lois Dodd in the Tanager Gallery, Drummond responded that both ladies were the primary ones responsible for cleaning the building. ${ }^{230}$ Moreover, Drummond says that she felt ignored by male and female artists and critics and in talking about the organized abstract expressionist communities, such as The Club, Drummond responded that those were "male enclave[s]."231 Due to her gender, she was systematically barred from much of the social networking of the key elements of the abstract expressionist community both by artists and critics.

That said, later writers and historians have considered and included Drummond within the context of Abstract Expressionism. Drummond was included in American Women Painters, a 1976 exhibition dedicated to highlighting women artists and combatting sexism in the arts. ${ }^{232}$ More recently, in 2003, her press release for her exhibition at the Mitchell Algus Gallery stated: "Along with Agnes Martin and Eleanore 
Mikus, Sally Drummond was notable as a woman artist whose meditative rigor stood in opposition to the gnawing machismo of Abstract Expressionism." 233

While Drummond may not have been consciously aware of her gender or its effect on her success within the 1950's art environment that she was an engaged participant in, the chauvinism of the movement and its participants surely were; her gender and standing as a female artist—as well as her developing iconoclasm involving most commonly held departures from tenets of 'conventional', Greenbergian Abstract Expressionism is likely a contributing factor to what Kramer referred to as her 'relative obscurity.' 


\section{CHAPTER IV}

\section{EXHIBITING ICONOCLASTIC FERVOR}

This chapter discusses how the thesis argued in Chapters I-III was articulated in the exhibition Iconoclastic Fervor: Sally Hazelet Drummond's Road to Abstraction that was held in Gallery X at the Hite Art Institute November 19-December $18^{\text {th }}, 2015$. The text explains how I have sought to present my ideas regarding the understanding and the importance of Drummond's work declared in the thesis in the exhibition of Drummond's art. It includes thoughts on curatorial practice, discusses the mechanics of the exhibition, the exhibition text and accompanying catalogue and includes plans for an evaluation of the show.

As a note, the full title of the exhibition is Iconoclastic Fervor: Sally Hazelet Drummond's Road to Abstraction but, for the ease of the reader, the exhibition title in this section has been shorted to Iconoclastic Fervor.

\section{CURATORIAL PRACTICE}

\section{INTRODUCTION}

In order to discuss the exhibiting of Iconoclastic Fervor, the term and understanding of an exhibition must first be explored. The text, An Introduction to Museum Work, published in 1997, proffers a basic definition of the term: "The term 'exhibit' carries the connotation that something has been added to the object or objects shown (interpretation) in order to accomplish something of importance (education, in the 
broad sense). ${ }^{234}$ Moreover, the exhibitions of an institution are representative of the organization's "public face."235

With the aforementioned statements in mind, the exhibition Iconoclastic Fervor: Sally Hazelet Drummond's Road to Abstraction, presents fourteen works of art by Sally Hazelet Drummond spanning from c. 1940s to 2010, a comprehensive survey of her working career from her earliest days to its effective conclusion. Each selected representative work was paired with short text labels and introduced by a longer interpretive panel placed at the entrance of the exhibition.

Iconoclastic Fervor was mounted in partial fulfillment for my master's degree in critical and curatorial studies from the University of Louisville, so the exhibition is both part of the 'public face' of the Hite Art Institute and a reflection on the University of Louisville and the Hite Art Institute, their missions and a personal statement on my understanding of the art and artist.

The mission statement for the University of Louisville is as follows:

The University of Louisville shall be a premier, nationally recognized metropolitan research university with a commitment to the liberal arts and sciences and to the intellectual, cultural, and economic development of our diverse communities and citizens through the pursuit of excellence in five interrelated strategic areas: 1.) Educational Experience, 2.) Research, Creative, and Scholarly Activity, 3.) Accessibility, Diversity, Equity, and Communication, 4.) Partnerships and Collaborations, and 5.) Institutional Effectiveness of Programs and Services. ${ }^{236}$

Iconoclastic Fervor is also linked to the Hite Art Institute's mission:

The mission of the Hite Art Institute is to educate our students to function in the forefront of the art world, to inspire critical thinking, promote a 
diversity of perspectives, and engage in the most current scholarship in art history, theory, studio art, and curatorial practices. ${ }^{237}$

My selection of Sally Hazelet Drummond for my thesis exhibition was influenced by the fact that she was an early graduate of the Hite Art Institute's studio master's program and is believed to hold the status of the first woman to graduate. However, the artist is relatively unknown in the Louisville community despite her success and importance in the abstract expressionist movement and her distinguished career.

The exhibition and thesis was an opportunity to contribute to the scholarship about the artist as well as add to the art historical understanding of Abstract Expressionism. George Ellis Burcaw states in Introduction to Museum Work, "an exhibit should be designed so as to produce a particular result. To decide what to exhibit, how, and where, without first deciding why, is questionable procedure. Just as a museum should have a purpose, an exhibit should have a purpose." ${ }^{, 238}$ Beyond having been completed in partial fulfillment for a master's degree in critical and curatorial studies, the purpose of the exhibition was to highlight the art and career of Sally Hazelet Drummond and to expand the understanding of Abstract Expressionism as an ideology as well as a movement.

Another purpose that is articulated in the interview conducted with the artist July $25^{\text {th }}, 2015$ in Germantown, New York, was to resuscitate the memory of the artist within the city of Louisville and to reacquaint the city with the work and success of Sally Hazelet Drummond. ${ }^{239}$ I was fascinated that Drummond had been shown and collected in major American museums, and was the first female graduate student in painting from the 
University of Louisville but whose story was little known and that I had become familiar with her work only late in my study at the University of Louisville.

\section{CURATORIAL ROLES}

While the roles of a curator are often inter-related and span several categories, the most pronounced roles in this exhibition has been the research, selection and design of the exhibition. Also outlined in Introduction to Museum Work the research role is critical- the text emphatically asserts "surely the curators must be capable, or they should not be

curators. ${ }^{240}$ Curators are responsible for ensuring that their presentations are factual and are grounded in strong academic precedents. Since museums, particularly in an academic setting, are viewed as an authority, the objects and interpretations they present must be grounded in solid scholarly research. Therefore, I focused on putting Iconoclastic Fervor in a plausible scholarly context within the history of the artist's formative period. This necessitated examining and presenting how Drummond's work both evolved out of and extended beyond usual understandings of the abstract expressionist style.

In addition to presenting the ideas I developed regarding Drummond's work, the task and challenge was to present this story to a variety of visitors with different levels of familiarity with art, art history, or aesthetic appreciation in a manner that was understandable, accessible and within budget and resource capabilities of the Hite galleries. Articulated by Burcaw, "Part of the museum curator's job is to abstract, simplify, and make interesting the important information about the objects shown. Do not attempt to say everything that can be said. Do not dwell on unimportant details. Leave them for the pamphlets and books. ${ }^{, 241}$ In Iconoclastic Fervor, the most concise 
information was presented in the exhibition handout, interpretive panel and in the description on the label for each work. A fuller accounting was included in the exhibition catalogue.

\section{CURATORIAL PRACTICE}

Contemporary museum practice has increasingly turned towards accommodating the museum visitor. Museums, and in this case, galleries, have historically been viewed as holding hegemony over culture which often resulted in a didactic attitude towards their visitor base. This attitude is perhaps best articulated in the 1910 Bulletin of the Met which provided "some visitors are qualified to be their own interpreters. Most visitors are not." ${ }^{242}$ While museums, and curators in particular are expected to be well-versed in their collections' history and significance, conveying an attitude of cultural suprematism is no longer current museum practice. However, even today, the methodology and degree to which institutions work to appeal to their visitors is widely varied.

Visitor-centricity and accessibility are interconnected concepts that represent current best practices in museology. As implied by the term, visitor-centricity connotes a consideration of the visitor's perspective in every aspect of museum planning from exhibition design to operations protocols. Accessibility includes the same considerations but for differing audiences, including those that are typically underserved such as persons with disabilities or those individuals who rarely if ever visit museums. John Cotton Dana is considered a pioneer of both fields in museology in his 1917 text, "The Gloom of the Museum." His early critique lambasts much of the pretentiousness of museum collections, staff and planning that are still being heralded today. ${ }^{243}$ John H. Falk and 
Lynn D. Dierking were recent professionals to raise the charge of visitor-centricity and access in contemporary museology. In their seminal text, The Museum Experience, published in 1992, the authors highlighted the effect of the museum on the visitor by tracing the museum visit from its conception, the first inkling that an individual considers visiting an institution, to recall of visits years later. ${ }^{244}$ In keeping with contemporary practice, Iconoclastic Fervor was designed with great consideration for the gallery visitor's needs, interest and perspective.

\section{ICONOCLASTIC FERVOR, THE EXHIBITION}

\section{AUDIENCE}

Often, museum professionals generalize their visitor base as 'the general public.' However, as Burcaw has stated 'Thinking of museum visitors as 'the general public' and assuming that they are all pretty much alike is an ignorant or a lazy escape from thinking of visitors as representing many 'publics' or as being individuals." ${ }^{\text {"24 }}$ It is more accurate to think of museums as serving many publics and the audience for Iconoclastic Fervor is no exception.

For the exhibition, the primary audience is likely to be the University and particularly, Hite students and staff- to be more specific, most of the audience members are usually in the category of those who are affiliated or are familiar with the campus. However, another secondary audience that I particularly wanted to address is the Louisville community at large. 
Press releases, email reminders and social media announcements are disseminated through the Hite Art Institute's email list that is fairly extensive but generally University and alumni focused. Therefore, additional effort was necessary to attempt to reach a broader community. The location of the exhibition in the arts building on main campus presents another challenge to non-University affiliated visitors. Attempts to draw the Louisville community included public relation announcements outside of the University and through a corollary event at the exhibition opening.

To gain a wider audience within the Louisville community, I reached out to local art writers and critics, including Courier Journal Art Critic, Elizabeth Kramer and Keith Waits from Arts Louisville. I have a broadcast slot with Marianne Zickuhr of Fleur de Arts. Additionally, I have met with Niki King, Communication and Marketing Specialist, from the University of Louisville to see how to best promote the exhibition to the Louisville audience. Moreover, I have printed additional cards to be placed within Louisville Galleries to reach an audience who might not receive email notifications. While there is little programming for the exhibition, I have scheduled a jazz musician to perform at the exhibition opening as a nod to Dore Ashton's Lyrical Abstraction that paired Drummond's work, among others, with jazz music and possibly draw in further audiences. ${ }^{246}$ While it is impossible to know the result of these efforts at the moment, the aforementioned efforts demonstrate a curatorial intent to reach a non-traditional audience, the larger Louisville community. From the exhibition labels to the catalogue specific details have been drawn in order to create connections with the Louisville audiences. 


\section{INTERPRETATION}

As outlined in the subsection on curatorial roles, part of the responsibility of the curator is to pair the object, in this case, the art, with text that provides at a minimum, the art, title, date and medium, and, preferably contextualizes the artifact and contributes to the thesis of the exhibition. The pairing of text with artifacts, interpretation, were in use by the outset of WWI and include catalogues, brochures and labels. ${ }^{247}$ Iconoclastic Fervor included all three interpretive vehicles. With interpretation, there is always an attempt to balance inundating visitors with too much information and providing too little information. Art museums and galleries are often culprits of the latter due to the belief that interpretation is an intrusion to the visitor's private act of viewing and that the 'art speaks for itself. ${ }^{248}$ However, my curatorial practice takes this point of view to be elitist and is anathema to accessibility in museums. Should visitors prefer to view the art unencumbered by interpretation, they have the option to disregard the object label whereas 'uninitiated' visitors seeking interpretation are left in want if there is no information available.

Exhibition interpretations are imperative communication tools between the visitor and the curator and facilitate understanding and appreciation of the object and exhibition. Introduction to Museum Work outlined that good labels are those that are visible, legible, relate to the object and contribute to the overall goal and that they fit into the aesthetic of the exhibition. ${ }^{249}$ Other scholars have added to this list by including that interpretation must be interesting. In expanding on the importance and accessibility of text within museums, Lisa Roberts has stated "interpretation was about communication; and 
effective communication required bridging the world of the expert and the world of the layperson with language that was intelligible to the latter without being a misrepresentation of the former.",250

All of the interpretation for the exhibition, from the catalogue to object labels, were written to adhere to the standards aforementioned. Interpretation on object labels was also written to accommodate the average museum reading speed of five words per second and are kept to around fifty words so that visitors can read the labels in ten seconds or less to accommodate the average attention span for visitors. ${ }^{251}$ Object labels were printed and laid out in keeping with the traditional graphic design of the Schneider Galleries to maintain the overall aesthetic. The object labels were then hung fifty-four inches from the floor to ensure they can be read by persons of different heights and persons with disabilities as recommended by the Standard Manuals for Signs and Labels published by the Professional Practice Series. ${ }^{252}$ Similarly, the introductory text, while longer than the fifty-word maximum of the object labels, was written with brevity and accessibility in mind and was kept under three hundred words as recommended by Beverly Serrell. ${ }^{253}$ The text was printed as to be legible from a distance at fourteen point font and was written to be compelling without being didactic or cumbersome. Lastly, the catalogue and brochure provided the most interpretation but were still written with the same visitor-centric guidelines that are outlined above. As a result, for visitors seeking a solo encounter with the artwork on display had the option of ignoring the text provided and visitors seeking interpretation had access to a multiplicity of interpretive vehicles. A copy of the interpretive panel, object labels and the curatorial essay for the catalogue are included in the addendum. 
Moreover, another important curatorial practice in Iconoclastic Fervor was to utilize the voice of the artist as much as possible and to alternatively downplay the curator as the sole authority. All of the exhibition text, from the object labels to the brochures included quotes from the artist. The artists voice was also prominently displayed in the gallery in the form of three vinyl artist's statements that hung above the artwork. These statements, included in addendum, were selected to reinforce the thesis and illustrated, in the artist's own words, the thesis of the exhibition. The catalogue also made extensive use of Drummond's words either directly or by proxy; the essays included an interview with the artist and Lois Dodd, Drummond's contemporary and friend, wrote another essay about the artist. Moreover, there was an entire section of the catalogue that featured four artist's statements, all of which were selected to reinforce the thesis of the exhibition. While there were prefaces and afterwards that provided contextualization for these works, Drummond's words served as the main voice of the catalogue. Highlighting the voice of the artist was an important curatorial strategy for Iconoclastic Fervor.

\section{EXHIBITED WORKS}

Iconoclastic Fervor included fourteen works of art produced by Sally Hazelet Drummond from c. 1940s to 2010 and thus span the artist's career. The exhibition included one work from the University of Louisville's Hite Art Institute's collection with the remaining thirteen works of art having been loaned from New York and the Louisville area. Three works of art were borrowed directly from the artist. These are the best representations of her early artistic career, Girl in a Doorway 1949 (Figure 2.), 
Magician, 1951 (Figure 3.) and Untitled, c. 1952 (Figure 4.) and have not been widely exhibited but are crucial to understanding her artistic development. Two works were loaned by John Clark, the artist's nephew-- Girl Sitting, c.1940s (Figure 1.), the earliest work in the exhibition and A Simple Arrangement, 1969 (Figure 7.). Another work of the artist's pointillist starburst images, Morning, 1997 (Figure 13), was also loaned by a Louisville resident, the artist's niece, Craig Clark. The remaining seven artworks, which are from the artist's fully mature period, were loaned by Alexandre Gallery in New York City.

The artwork was selected to advance the thesis of the show; to demonstrate Drummond's conventional entry-point to Abstract Expressionism via figurative work that draws heavily on Cubism and her traditional gestural abstract expressionistic work, like Unititled c. 1952 (Figure 4.). The remaining works articulate the artist's break from conventional abstract expressionistic works into her own oeuvre of pointillist aerole-like images that, with the exception of the shift from a dark to a light core, remained fairly constant. Thus, the art selected illuminates Abstract Expressionism as an ideology and highlights the artistic career of Sally Hazelet Drummond. The art was arranged chronologically to fit the theme of the show and to show the artist's development over time. The art was hung centered across the gallery at sixty-three inches to accommodate for the average viewing height as suggested by David Dean in Museum Exhibition:

Theory and Practice. ${ }^{254}$ 


\section{LOCATION}

Iconoclastic Fervor was held at Gallery X in Schneider Gallery from November $19^{\text {th }}$-December $18^{\text {th }}, 2015$. It was important to hold the exhibition within the city of Louisville due to Drummond's affiliation with the city as her alma mater, her family's residence, and an exhibition location in 1951, 1952, 1955, 1961, 1987 and, prior to this exhibition, most recently in $1990 .{ }^{255}$ This exhibition marked the first show of Drummond's work in Louisville in twenty-five years and her first show at the University of Louisville. Thus, it was important not only to host her exhibition within the city of Louisville, but specifically at the University of Louisville where she had never been exhibited.

Schneider Gallery, located within Schneider Hall offers admission free of charge and is open daily. Schneider Gallery is open Monday through Friday from 9:00am until 4:30pm, and Saturday and Sunday from 1:00pm -5:00pm. While the hours are not particularly expansive, the free admission and weekend hours fulfill part of my curatorial intention of increased accessibility.

Gallery X can only be entered through the Belknap Gallery just off of the lobby of Schneider Hall. The gallery has a wall of windows that renders that wall unusable but provides an attractive north light in which to see the art, leaving three walls for hanging space, two of which have doorways that further disrupt the hanging space.

In coping with the architecture of the space, the exhibition was laid out to present the clearest path for the viewer. Studies of visitor flow patterns have demonstrated that 
viewers typically turn to the right upon entering a gallery. As a result, I placed a false wall on the immediate right of the entrance that featured the longer interpretive panel for the exhibition. After reading the text, visitors are then directed to start the exhibition to the right of the doorway and then follow it chronologically across the room until they reach the final work on the opposite side of the false wall. A diagram of the layout is also included in the addendum. While the flow is not ideal, the layout was the best means of creating cohesion within the space.

Another consideration for the visitor that I employed in the exhibition layout included the placement of a bench. 'Museum fatigue' is a commonly described phenomenon that includes mental and physical exhaustion from perusing galleries. While the Schneider Galleries are relatively modest in size and 'museum fatigue' is less likely, the presence of benches accommodates viewers who wish to sit and conveys to visitors that they are encouraged to linger in the environment. Benches were integrated into museums beginning in the 1920s and were a direct response to the phenomenon of 'museum fatigue;' their inclusion in this exhibition demonstrates my curatorial practice and dedication towards accessibility and visitor-centricity. ${ }^{256}$ Moreover, the presence of the bench reinforces the notion that the art necessitates prolonged looking-Drummond herself described her art as inspiring contemplation, the use of benches permit the viewing of the art as intended by the artist. $^{257}$

\section{THE CATALOGUE FOR ICONOCLASTIC FERVOR}

It was decided early on in the exhibition planning that there would be a catalogue produced. John Clark, the artist's nephew, is the owner of Old Stone Press, a local 
publishing company. Clark agreed to publish a catalogue from the outset and it was decided that it was in the best interest for all parties; the catalogue would produce a permanent record of the exhibition and thus benefit the artist, university, visitors and other interested parties and myself. The catalogue included three sections: Selected Essays - containing the curatorial essay, an essay by the only other female member of the Tanager Gallery, Lois Dodd, and an interview with the artist all of which were written in 2015, Artist's Statements included four texts written by the artists between 1952 and 1989 that I selected in order to illustrate the artist's journey to abstraction and her own iconoclastic spirit that helped to push the boundaries of conventional Abstract Expressionism, the last section Exhibited Works, included the image and basic information about the fourteen works of art included in Iconoclastic Fervor. Ancillary to the sections were the acknowledgements page and the artist's curriculum vitae. This documentation of the artist is particularly important since the lack of other monographs and reproductions inhibit the ability to know and understand the artist's contributions to Abstract Expressionism and the art history of the 1950s in New York. Making available and listing sources of the artist's writing is also a curatorial intention that is embodied in the catalogue.

\section{REFLECTING ON ICONOCLASTIC FERVOR}

Feedback is an important methodology in contemporary curatorial practice and is tied to visitor-centricity as curators take increased interest in the visitor experience; while it is impossible to know what the feedback for Iconoclastic Fervor will be prior to the exhibition's opening, evaluative feedback has been built into the exhibition as part of the professional practice. Beverly Serrell has written extensively on the topic and her text 
was a resource in creating my own evaluation form. ${ }^{258}$ However, Serrell's proposed form is cumbersome so I created an abbreviated form that is included in the addendum. The form includes four questions, a section for general comments or questions and my contact information so that any visitors may contact me directly in order to have a dialogue about any comments or concerns. This was also part of my curatorial intention of accessibility in that most evaluative forms simply prompt visitors to leave their opinions without the option to converse with staff members. The form was available in the gallery itself for any visitors but I also partnered with Peter Morrin at the University of Louisville to have his students in his course "Understanding Museums" provide feedback using the form or their own preferred format. 


\section{CONCLUSION}

\section{SALLY HAZELET DRUMMOND’S ICONOCLASTIC FERVOR}

Sally Hazelet Drummond began her professional career working in a manner similar to the first generation abstract expressionists such as, her influence, Willem De Kooning. As part of the New York scene in the 1950's, she was influenced by both the artists and the critics surrounding the rather heated and misogynistic milieu but ultimately broke away from many of the tenets set out by Clement Greenberg and other writers and created her own independent course of artistic expression. Drummond understood the movement as an ideology, one that encouraged artist to question and expand the boundaries of artistic expression. Inspired by the movement's initial iconoclasm, Drummond adopted the artistic spirit set forth by previous abstract expressionists and awakened a desire to continue to push further, her challenge to the commonly understood norms of the movement are as iconoclastic as the confrontation the first generation abstract expressionists presented the post-war art world. Irving Sandler's curatorial statement for Drummond's exhibition at Artist's space is notable for its articulation the artists' adoption of the iconoclastic spirit of Abstract Expressionism:

In the mid-fifties, Sally Hazelet Drummond was a mainstay of the Tanager Gallery, the first and leading of the artists cooperatives on Tenth Street and an example for the many which followed. It is fitting that she should exhibit at Artists Space, an alternative gallery now in its tenth year and a prototype for dozens throughout America, since its inception its founder had the Tanager Gallery very much in mind. More important, this show is a tribute to Drummond as an artist.

When Drummond first began to show on Tenth Street, the common denominator of New York School painting was a "painterly" or "gestural" look. Although art in this vein was generally labeled Abstract Expressionism, most of it was neither abstract, nor Expressionist in the 
sense of being violent or aggressive, raw and "ugly." However, Expressionist painters, for example, de Kooning, Kline and young artists inspired by them, did receive relatively more attention than their quieter colleagues, such as Guston.

In fact, fifties painting was far more varied than it is now remembered to have been. And if there was violence, there was also lyricism - and contemplation, none quieter than Drummond's abstract images. And yet, they were shocking, more shocking than most of the canvases which set out to shock. The reason was that Drummond's pictures were monochromatic fields, coloristic and painterly to be sure but too minimal to be accepted by more than a few handfuls of artists and critics.

Drummond had no intention at all of shocking anyone. She simplified color and gesture, ending up with one-color fields of subtly nuanced surfaces, in order to create a "World of Silent Painting," as she wrote at the time. In 1956, Drummond began to deepen slightly the color in the centers of her pictures, providing a focus for contemplation. By 1960, she began to use a pointillist technique to slowly build up a vibrating, all-over image and at the same time to accent more than before the centrifugal, aureole-like radiation. It was not only the finished image but the awareness of how it came into being, the pointillist technique itself, that generated a meditative mood. The viewer experienced the slow singleminded addition of dot to dot, each subtly modulated in tone so as to create a luminous field. Since 1960 Drummond has been refining and intensifying her serene and radiant images.

A final historic note: last winter, two excellent and much-discussed gallery shows - Paint as Image at the Max Hutchinson Gallery and New Abstraction at the Sidney Janis Gallery - featured painterly monochromatic abstractions. Neither included Sally Hazelet Drummond, most likely because her work was not well enough known to the organizers. The omission was unfortunate since it was she and the late Ben Isquith, with an eye to Reinhardt on the one hand, and, on the other hand to Guston, who ushered in the tendency during the early fifties. Thus, the Artist Space show offers works that help set history straight and, more important, that, to paraphrase Matisse, soothe the soul. ${ }^{259}$

Sandler's quote elucidates many of the points in this thesis and the last paragraph notes contemporary omissions of her art indicate the historical record. This tendency to hold steadfastly to conventional understandings of Abstract Expressionism continues to this day. However careful observation of Drummond's work and career clearly demonstrates 
the need for a revision of her status and the larger need to expand the understanding of Abstract Expressionism.

\section{AN EXPANDED DEFINITION}

As Sandler declared in "Abstract Expressionism: The Noise of Traffic on the Way to Walden Pond" written in 1993, in referring to the myriad of art created under the titled Abstract Expressionism, "No label can encompass a group as diverse as Jackson Pollock, Willem de Kooning, Mark Rothko, Franz Kline, Clyfford Still and Ad Reinhardt. Yet it is in the nature of art critics and historians to search for affinities and if possible to categorize their subjects. ${ }^{, 260}$ It is exactly the attempt at categorization that has created a narrow understanding of the movement.

In the eighties and nineties, scholars and curators began seeking to expand the cannon and understanding of the movement. In a call for papers for the 1990 meeting of the College Art Association's conference one session was titled “Abstract Expressionism's Others" in which contributors were encouraged to explore artists and styles that have been eclipsed from historical accounts. ${ }^{261}$ Ann Eden Gibson has also accepted the charge to expand the understanding of Abstract Expressionism in her 1997 book Abstract Expressionism: Other Politics. In the text, Gibson explored 'minor' abstract expressionist women, homosexuals, bisexuals or persons of color who all exhibited with canonized members of the movement but who were left out of the literature and systematically barred from full participation and success. ${ }^{262}$ 
Drummond was included in an exhibition at the P.S. 1 titled "Underknown: Twelve Artists Re-Seen in 1984" that, like the pilot series Drummond was included in 1989 at Artists Space, sought to highlight artists left out of critical canons. ${ }^{263}$ Two exhibitions on display and to be installed shortly after the publication of this thesis in 2015 also tap into this revisionist sentiment. Jack Tworkov: Mark and Grid at the Alexander Gray Associates in New York, New York explores the career and 'quieter' abstract expressionist art of the first-generation abstract expressionist and studio-mate of Willem de Kooning. ${ }^{264}$ The Denver Art Museum is also planning to mount an exhibition titled Women of Abstract Expressionism that is highlighting twelve well-known and underknown female abstract expressionists. ${ }^{265}$

Within the narrow classification and understanding of 'traditional' Abstract Expressionism, many artists who presented work that slightly stretched definitions or did not exactly fit the critical rhetoric of the style defined by its most prominent critics have been left out. This thesis, and the accompanying exhibition seeks to clearly place Sally Hazelet Drummond within the boundaries of the movement and to show how her work possesses and embodies the iconoclastic fervor that she wrote about in her early statements about her motivations and aspirations.

What began as an avant-garde reaction to limitations placed on artists by both critics and the public, in turn has become a restrictive dogma in its own right. Abstract Expressionism can be best understood as varied style that, was participated in by a myriad of artists working in a variety of ways including Drummond's 'Silent Painting.' This exhibition and thesis is an attempt to advocate a revisioning of Abstract 
Expressionism to reintroduce, reacquaint and relocate the work a revolutionary but underknown abstract expressionist, Sally Hazelet Drummond. 


\section{REFERENCES}

${ }^{1}$ Sally P. Hazelet. “A Commentary on my Painting," Master's Thesis (University of Louisville, 1952), 14.

${ }^{2}$ Ronald Bladen, Lois Dodd, Sally Hazelet Drummond, Al Held, Alex Katz, William King, Philip Pearlstein and George Sugarman, Eight Begin: Artists' Memories of Starting Out, Edited by Ada Katz (Waterville: Colby Museum of Art, 2014), 35.

${ }^{3}$ Ibid, 34.

${ }^{4}$ Sally Hazelet Drummond, Sally Hazelet Drummond in discussion with the author, July 25, 2015, Germantown, New York, See Addendum of Hillary Sullivan's Master's Thesis, University of Louisville, 40.

${ }^{5}$ Ronald Bladen, Lois Dodd, Sally Hazelet Drummond, Al Held, Alex Katz, William King, Philip Pearlstein and George Sugarman, Eight Begin: Artists' Memories of Starting Out, Edited by Ada Katz (Waterville: Colby Museum of Art, 2014), 34. ; Sally Hazelet Drummond, Sally Hazelet Drummond in discussion with the author, July 25, 2015, Germantown, New York, See Addendum of Hillary Sullivan's Master's Thesis, University of Louisville, 40.

${ }^{6}$ Ronald Bladen, Lois Dodd, Sally Hazelet Drummond, Al Held, Alex Katz, William King, Philip Pearlstein and George Sugarman, Eight Begin: Artists' Memories of Starting Out, Edited by Ada Katz (Waterville: Colby Museum of Art, 2014), 33.

7 Sally Hazelet Drummond, Sally Hazelet Drummond in discussion with the author, July 25, 2015, Germantown, New York, See Addendum of Hillary Sullivan's Master's Thesis, University of Louisville, 2.

8 Ibid, 49-51.

${ }^{9}$ Ronald Bladen, Lois Dodd, Sally Hazelet Drummond, Al Held, Alex Katz, William King, Philip Pearlstein and George Sugarman, Eight Begin: Artists' Memories of Starting Out, Edited by Ada Katz (Waterville: Colby Museum of Art, 2014), 36.

10 Sally Hazelet Drummond, Sally Hazelet Drummond in discussion with the author, July 25, 2015, Germantown, New York, See Addendum of Hillary Sullivan's Master's Thesis, University of Louisville, 49.

${ }^{11}$ Ronald Bladen, Lois Dodd, Sally Hazelet Drummond, Al Held, Alex Katz, William King, Philip Pearlstein and George Sugarman, Eight Begin: Artists' Memories of Starting Out, Edited by Ada Katz (Waterville: Colby Museum of Art, 2014), 40.

12 Sally Hazelet Drummond, Sally Hazelet Drummond in discussion with the author, July 25, 2015, Germantown, New York, See Addendum of Hillary Sullivan's Master's Thesis, University of Louisville, 56.

13 Ibid, 3, 49.

${ }^{14}$ Joellen Bard, Pleiades Gallery, Association of Artist-Run Galleries, Amos Eno Gallery, Dore Ashton, Bruno Palmer-Poroner, Lawrence Alloway, Tenth Street Days: The Co-ops of the 50's: The Galleries: Tanager, Hansa, James, Camino, March, Brata, Phoenix, Area (New York: Education, Art \& Services Inc., 1977), Exhibition Catalogue, 1.

15 Sally Hazelet Drummond, draft for speech for Cornell Art Gallery, Rollins College, Speech delivered September 25, 1989, multiple drafts (Sally Hazelet Drummond Papers. In the possession of Sally Hazelet Drummond). ; Sally Hazelet Drummond, curriculum vitae, Undated, multiple copies (Sally Hazelet Drummond Papers. In the possession of 
Sally Hazelet Drummond). ; Sally Hazelet Drummond, "Sally Hazelet Drummond" [curriculum vitae], Undated (Alexandre Gallery).; Sally Hazelet Drummond, Sally Hazelet Drummond in discussion with the author, July 25, 2015, Germantown, New York, See Addendum of Hillary Sullivan's Master's Thesis, University of Louisville, 59.

${ }^{16}$ Ronald Bladen, Lois Dodd, Sally Hazelet Drummond, Al Held, Alex Katz, William King, Philip Pearlstein and George Sugarman, Eight Begin: Artists' Memories of Starting Out, Edited by Ada Katz (Waterville: Colby Museum of Art, 2014), 33.

${ }^{17}$ Sally Hazelet Drummond, Sally Hazelet Drummond in discussion with the author, July 25, 2015, Germantown, New York See Addendum of Hillary Sullivan's Master's Thesis, University of Louisville, 60. ; Sally Hazelet Drummond, draft for speech for Cornell Art Gallery, Rollins College, Speech delivered September 25, 1989, multiple drafts (Sally Hazelet Drummond Papers. In the possession of Sally Hazelet Drummond) ${ }^{18}$ Sally Hazelet Drummond, Sally Hazelet Drummond in discussion with the author, July 25, 2015, Germantown, New York, See Addendum of Hillary Sullivan's Master's Thesis, University of Louisville, 61.

${ }^{19}$ Sally Hazelet Drummond, draft for speech for Cornell Art Gallery, Rollins College, Speech delivered September 25, 1989, multiple drafts (Sally Hazelet Drummond Papers. In the possession of Sally Hazelet Drummond).

${ }^{20}$ Ibid. ; Sally Hazelet Drummond, Sally Hazelet Drummond in discussion with the author, July 25, 2015, Germantown, New York, See Addendum of Hillary Sullivan's Master's Thesis, University of Louisville, 5-6. ; Ronald Bladen, Lois Dodd, Sally Hazelet Drummond, Al Held, Alex Katz, William King, Philip Pearlstein and George Sugarman, Eight Begin: Artists' Memories of Starting Out, Edited by Ada Katz (Waterville: Colby Museum of Art, 2014), 33.

${ }^{21}$ Sally Hazelet Drummond, draft for speech for Cornell Art Gallery, Rollins College, Speech delivered September 25, 1989, multiple drafts (Sally Hazelet Drummond Papers. In the possession of Sally Hazelet Drummond).

22 Ibid.

${ }^{23}$ Ibid. ; Clement Greenberg, Clement Greenberg: Late Writings, Edited by Robert C. Morgan (Minneapolis: University of Minnesota Press, 2003) 204-229.

${ }^{24}$ Sally Hazelet Drummond, draft for speech for Cornell Art Gallery, Rollins College, Speech delivered September 25, 1989, multiple drafts (Sally Hazelet Drummond Papers. In the possession of Sally Hazelet Drummond). ; Sally Hazelet Drummond, Sally Hazelet Drummond in discussion with the author, July 25, 2015, Germantown, New York, See Addendum of Hillary Sullivan's Master's Thesis, University of Louisville, 5-6. ${ }^{25}$ Sally P. Hazelet. "A Commentary on my Painting," Master's Thesis (University of Louisville, 1952), 10.

${ }^{26}$ Sally Hazelet Drummond, draft for speech for Cornell Art Gallery, Rollins College, Speech delivered September 25, 1989, multiple drafts (Sally Hazelet Drummond Papers. In the possession of Sally Hazelet Drummond).

27 Sally P. Hazelet. "A Commentary on my Painting," Master's Thesis (University of Louisville, 1952), 12.

${ }^{28}$ Sally Hazelet Drummond, draft for speech for Cornell Art Gallery, Rollins College, Speech delivered September 25, 1989, multiple drafts (Sally Hazelet Drummond Papers. In the possession of Sally Hazelet Drummond). 
${ }^{29}$ Hugo Weber, Elayne H. Varian and Finch College Museum of Art, Hugo Weber: A Retrospective Exhibition (New York: Finch College Museum of Art, 1975), Exhibition Catalogue.

30 Sally P. Hazelet. “A Commentary on my Painting," Master's Thesis (University of Louisville, 1952), 19.

${ }^{31}$ Robert Motherwell, Dore. Ashton, Jack D. Flam, Robert T. Buck, and Albright-Knox Art Gallery, Robert Motherwell (New York: Abbeville Press, 1983), Exhibition Catalogue.

32 Sally P. Hazelet. "A Commentary on my Painting," Master's Thesis (University of Louisville, 1952), 13.

33 Sally Hazelet Drummond, Sally Hazelet Drummond in discussion with the author, July 25, 2015, Germantown, New York, See Addendum of Hillary Sullivan's Master's Thesis, University of Louisville, 5-6, 46-48, 63, 68. ;Sally Hazelet Drummond, draft for speech for Cornell Art Gallery, Rollins College, Speech delivered September 25, 1989, multiple drafts (Sally Hazelet Drummond Papers. In the possession of Sally Hazelet Drummond).

${ }^{34}$ Art Center Association, "Ulfert Wilke" Art Center Association, Louisville, Kentucky, Undated, Biography, Chronology and Curatorial Statement (Artists' Files, Ulfert Wilke, University of Louisville Margaret M. Bridwell Art Library).

35 Sally Hazelet Drummond, Sally Hazelet Drummond in discussion with the author, July 25, 2015, Germantown, New York, See Addendum of Hillary Sullivan's Master's Thesis, University of Louisville, 44-47, 63, 69. ; Sally Hazelet Drummond, draft for speech for Cornell Art Gallery, Rollins College, Speech delivered September 25, 1989, multiple drafts (Sally Hazelet Drummond Papers. In the possession of Sally Hazelet Drummond).

36 Sally P. Hazelet. "A Commentary on my Painting," Master's Thesis (University of Louisville, 1952), 20.

37 Sally Hazelet Drummond, Sally Hazelet Drummond in discussion with the author, July 25, 2015, Germantown, New York, See Addendum of Hillary Sullivan's Master's Thesis, University of Louisville, 5-6.

38 Sally P. Hazelet. "A Commentary on my Painting," Master's Thesis (University of Louisville, 1952), 5.

39 Ibid.

40 Ibid, 6.

${ }^{41}$ Ronald Bladen, Lois Dodd, Sally Hazelet Drummond, Al Held, Alex Katz, William King, Philip Pearlstein and George Sugarman, Eight Begin: Artists' Memories of Starting Out, Edited by Ada Katz (Waterville: Colby Museum of Art, 2014), 37.

42 Sally P. Hazelet. "A Commentary on my Painting," Master's Thesis (University of Louisville, 1952), 17-26.

43 “Among Painters in New York Number Sally Hazelet As One," Courier-Journal (Louisville, KY), January 11, 1959, (Artists' Files, Sally Hazelet Drummond, Main Branch, Louisville Free Public Library).

44 Sally Hazelet Drummond, draft for speech for Cornell Art Gallery, Rollins College, Speech delivered September 25, 1989, multiple drafts (Sally Hazelet Drummond 
Papers. In the possession of Sally Hazelet Drummond). ; Ronald Bladen, Lois Dodd, Sally Hazelet Drummond, Al Held, Alex Katz, William King, Philip Pearlstein and George Sugarman, Eight Begin: Artists' Memories of Starting Out, Edited by Ada Katz (Waterville: Colby Museum of Art, 2014), 36-37.

45 Sally Hazelet Drummond, draft for speech for Cornell Art Gallery, Rollins College, Speech delivered September 25, 1989, multiple drafts (Sally Hazelet Drummond Papers. In the possession of Sally Hazelet Drummond). ; Ronald Bladen, Lois Dodd, Sally Hazelet Drummond, Al Held, Alex Katz, William King, Philip Pearlstein and George Sugarman, Eight Begin: Artists' Memories of Starting Out, Edited by Ada Katz (Waterville: Colby Museum of Art, 2014), 38-39.

${ }^{46}$ Ronald Bladen, Lois Dodd, Sally Hazelet Drummond, Al Held, Alex Katz, William King, Philip Pearlstein and George Sugarman, Eight Begin: Artists' Memories of Starting Out, Edited by Ada Katz (Waterville: Colby Museum of Art, 2014), 39.

47 Sally Hazelet Drummond, draft for speech for Cornell Art Gallery, Rollins College, Speech delivered September 25, 1989, multiple drafts (Sally Hazelet Drummond Papers. In the possession of Sally Hazelet Drummond).

48 Ibid.

${ }^{49}$ Sally Hazelet Drummond, draft for speech for Cornell Art Gallery, Rollins College, Speech delivered September 25, 1989, multiple drafts (Sally Hazelet Drummond Papers. In the possession of Sally Hazelet Drummond).

50 These figures were determined by going through the sizes of her work at Alexandre Gallery: Alexandre Gallery. "Sally Hazelet Drummond,"

Alexandregallery.com, http://www.alexandregallery.com/sally-hazelet-drummond. and by going through Sally Hazelet Drummond Papers.

51 Sally Hazelet Drummond, Sally Hazelet Drummond in discussion with the author, July 25, 2015, Germantown, New York, See Addendum of Hillary Sullivan's Master's Thesis, University of Louisville, 37-38. ; Linette Burton, "Drummonds Play and Paint in New Home on Wilton Road," October 24, 1963, (Sally Hazelet Drummond Papers. In the possession of Sally Hazelet Drummond).

52 Sally Hazelet Drummond, Sally Hazelet Drummond in discussion with the author, July 25, 2015, Germantown, New York, See Addendum of Hillary Sullivan's Master's Thesis, University of Louisville, 36-39, 51, 53, 57.

53 Roberta Smith, "Richard Bellamy, Art Dealer, Is Dead at 70," The New York Times (New York, NY), April 3, 1998, http://www.nytimes.com/1998/04/03/arts/richardbellamy-art-dealer-is-dead-at-70.html.

54 Ibid. ; Sally Hazelet Drummond, Sally Hazelet Drummond to Erik La Prade, October 9, 2009, (Sally Hazelet Drummond Papers. In the possession of Sally Hazelet Drummond) 2-4.

55 Sally Hazelet Drummond, curriculum vitae, Undated, multiple copies (Sally Hazelet Drummond Papers. In the possession of Sally Hazelet Drummond). ; Sally Hazelet Drummond, "Sally Hazelet Drummond" [curriculum vitae], Undated (Alexandre Gallery). ; Fischbach Gallery, "Sally Hazelet Drummond," Fischbach Gallery, Press Release, 1968, (Sally Hazelet Drummond Papers. In the possession of Sally Hazelet Drummond). ; Fischbach Gallery, "Sally Hazelet Drummond," Fischbach Gallery, New York, New York, April 22 - May 17, 1972, Exhibition Brochure, (Sally Hazelet 
Drummond Papers. In the possession of Sally Hazelet Drummond). ; Fischbach Gallery, "Sally Hazelet Drummond," Fischbach Gallery, New York, New York, November 18 December 6, 1978, Exhibition Brochure, (Sally Hazelet Drummond Papers. In the possession of Sally Hazelet Drummond).

56 Sally Hazelet Drummond, curriculum vitae, Undated, multiple copies (Sally Hazelet Drummond Papers. In the possession of Sally Hazelet Drummond). ; Sally Hazelet Drummond, "Sally Hazelet Drummond" [curriculum vitae], Undated (Alexandre Gallery).

${ }^{57}$ Elizabeth Leonard, "To Spend Year in France: Guggenheim for Artist," Ridgefield Area News (Ridgefield, CT), April 3, 1967, (Sally Hazelet Drummond Papers. In the possession of Sally Hazelet Drummond).

58 Sally Hazelet Drummond, Sally Hazelet Drummond in discussion with the author, July 25, 2015, Germantown, New York, See Addendum of Hillary Sullivan's Master's Thesis, University of Louisville, 64-67. ; Joan Kay, "Saturday Wedding Calls Family Home," Courier-Journal (Louisville, KY), June 26, 1968, (Sally Hazelet Drummond Papers. In the possession of Sally Hazelet Drummond).

59 Chuck Twardy, "Dynamic Dots Fill Drummond's Career," The Orlando Sentinel (Orlando, FL), September 8, 1989, (Sally Hazelet Drummond Papers. In the possession of Sally Hazelet Drummond).

60 The Corcoran Gallery of Art, "Sally Hazelet Drummond Retrospective," The Corcoran Gallery of Art, Washington, D.C.. November 3 - December 3, 1972, Exhibition Brochure, (Sally Hazelet Drummond Papers. In the possession of Sally Hazelet Drummond).

${ }^{61}$ Sue Scott, Gerald Nordland and Orlando Museum of Art. Washington Color Painters: The First Generation: Gene Davis, Thomas Downing, Morris Louis, Howard Mehring, Kenneth Noland, (Orlando: Orlando Museum of Art, 1990), Exhibition Catalogue.

62 Ibid.

63 Paul Richard, "Corcoran Combatants Seek Peace," The Washington Post (Washington, D.C.), November 5, 1972, (Sally Hazelet Drummond Papers. In the possession of Sally Hazelet Drummond). ; Paul Richard, "Raising the Corcoran Question," Unknown Source, Undated, (Sally Hazelet Drummond Papers. In the possession of Sally Hazelet Drummond). ; Benjamin Forgery, "The Art Galleries," The Evening Star and Daily News (Washington, D.C.), November 15, 1972, (Sally Hazelet Drummond Papers. In the possession of Sally Hazelet Drummond). ; Crosby, Thomas, "Art with a Punch," StarNews (Unknown). ca. 1972, (Sally Hazelet Drummond Papers. In the possession of Sally Hazelet Drummond).

${ }^{64}$ Hilton Kramer, "Art: Drummond Show at the Corcoran," The New York Times (New York, NY), November 24, 1972, (Sally Hazelet Drummond Papers. Alexandre Gallery). 65 Irving Sandler, From Avant-Garde to Pluralism: An On-The-Spot History (Lenox, MA: Hard Press Editions, 2006), 33.

66 Artists Space, "Sally Hazelet Drummond," Artists Space, New York, New York, February 25 - March 24, 1984, Exhibition Brochure (Artists' Files, Sally Hazelet Drummond, University of Louisville Margaret M. Bridwell Art Library). ; Artists Space, "Sally Hazelet Drummond: Paintings, 1971-84," Artists Space, Press Release, February 1984, (Sally Hazelet Drummond Papers. In the possession of Sally Hazelet Drummond). 
${ }^{67}$ Chuck Twardy, "Dynamic Dots Fill Drummond's Career," The Orlando Sentinel (Orlando, FL), September 8, 1989, (Sally Hazelet Drummond Papers. In the possession of Sally Hazelet Drummond).

68 Ramey, Lorrie Kyle, “An Illustrated Life," In Rollins Alumni Record, Winter 1990, 27 28, (Sally Hazelet Drummond Papers. In the possession of Sally Hazelet Drummond). ; The Cornell Fine Arts Museum, "Sally Hazelet Drummond," Rollins College, Winter Park, Florida, September 8 - October 15, 1989, Exhibition Mailer and Brochure, (Sally Hazelet Drummond Papers. In the possession of Sally Hazelet Drummond). ; Sally Hazelet Drummond, draft for speech for Cornell Art Gallery, Rollins College, Speech delivered September 25, 1989, multiple drafts (Sally Hazelet Drummond Papers. In the possession of Sally Hazelet Drummond).

69 Sally Hazelet Drummond, newspaper clippings, Undated, (Sally Hazelet Drummond Papers. In the possession of Sally Hazelet Drummond).

${ }^{70}$ Art Center Gallery. "Sally Hazelet." Art Center Gallery, Louisville, Kentucky. November 14 - December 6, 1957. Exhibition Brochure. Artists' Files, Sally Hazelet Drummond, University of Louisville Margaret M. Bridwell Art Library.

${ }^{71}$ Mitchell Algus Gallery. "Sally Hazelet Drummond: Paintings 1960-2000,” Mitchell Algus Gallery, New York, New York, October 18 - November 15, 2003, Exhibition Brochure, (Artists' File, Sally Hazelet Drummond, Alexandre Gallery). ; Mitchell Algus Gallery, "Sally Hazelet Drummond: Paintings 1960-2000," Mitchell Algus Gallery, New York, New York, October 18 - November 15, 2003, Exhibition Price List and Press Release, (Sally Hazelet Drummond Papers. In the possession of Sally Hazelet Drummond).

${ }^{72}$ Alexandre Gallery, "Sally Hazelet Drummond: Selected Paintings," Alexandre Gallery, New York, New York. October 27 - November 26, 2005, Press Release, October 2005 and Exhibition Brochure, (Artist's File, Sally Hazelet Drummond, Alexandre Gallery). ${ }^{73}$ E.C. Goosen, "Rothko: The Omnibus Image," Art News Volume 59, Number 9 (January 1961), 38.

${ }^{74}$ Irving Sandler, The Triumph of American Painting: A History of Abstract Expressionism (New York: Praeger, 1970), 2.

75 Artists Space, "Sally Hazelet Drummond," Artists Space, New York, New York, February 25 - March 24, 1984, Exhibition Brochure (Artists’ Files, Sally Hazelet Drummond, University of Louisville Margaret M. Bridwell Art Library). 76 Irving Sandler, The Triumph of American Painting: A History of Abstract Expressionism (New York: Praeger, 1970), 92.

77 Clement Greenberg, The Collected Essays and Criticism Volume IV: Modernism with a Vengeance 1957-1969, Edited by John O’Brian (Chicago: University of Chicago Press, 1993), 121, 215.

78 Irving Sandler, From Avant-Garde to Pluralism: An On-The-Spot History (Lenox, MA: Hard Press Editions, 2006), 241.

${ }^{79}$ Irving Sandler, The Triumph of American Painting: A History of Abstract Expressionism (New York: Praeger, 1970), 2.

80 Robert Goodnough Ed., "Artists' Sessions at Studio 35 (1950)," In Modern Artists In America, First Series, edited by Robert Motherwell and Ad Reinhardt, 8-23, (NewYork: Wittenborn Schultz, 1950), 22. 
81 Elaine De Kooning, Rose Slivka and Marjorie Luyckx, The Spirit of Abstract Expressionism: Selected Writings (New York: George Braziller, 1994), 13.

82 Ellen G. Landau, Reading Abstract Expressionism: Context and Critique (New Haven: Yale University Press, 2005), 229-236.

83 Clement Greenberg, The Collected Essays and Criticism Volume IV: Modernism with a Vengeance 1957-1969, Edited by John O’Brian (Chicago: University of Chicago Press, 1993), 123.

84 Ibid, 178.

85 Greenberg, Clement, "American-Type Painting” in Art and Culture, 1961, Reprint (Boston: Beacon Press, 1989) 208-229.

86 Harold Rosenberg, "The American Action Painters" in The Tradition of the New (New York: Horizon Press, 1959), 23-39.

${ }^{87}$ E.C. Goosen, "Rothko: The Omnibus Image," Art News Volume 59, Number 9 (January 1961), 38.

88 Paul Wood, Francis Frascina, Jonathan Harris and Charles Harrison, Modernism in Dispute: Art Since the Forties (New Haven: Yale University Press, 1993), 2-74.

${ }^{89}$ Museum of Modern Art. The New American Paintings As Shown in Eight European Countries, 1958-1959 (New York: Museum of Modern Art, 1959), 16.

90 Michel Seuphor, Lionel Izod, John Montague and Francis Scarfe, Dictionary of Abstract Painting with a History of Abstract Painting (New York: Tudor Publishing Company, 1957), 77.

${ }^{91}$ Museum of Modern Art, "German Expressionism," Museum of Modern Art, Accessed September 24, 2015, http://www.moma.org/explore/collection/ge/styles/index.

92 Clement Greenberg, The Collected Essays and Criticism Volume IV: Modernism with a Vengeance 1957-1969, Edited by John O'Brian (Chicago: University of Chicago Press, 1993), 72.

93 Museum of Modern Art, "Cubism," Museum of Modern Art Learning, Accessed September 24, 2015, https://www.moma.org/learn/moma learning/themes/cubism. 94 Museum of Modern Art, "Surrealism," Museum of Modern Art Learning, Accessed September 24, 2015, https://www.moma.org/learn/moma_learning/themes/surrealism. 95 Stephen Polcari, Abstract Expressionism and the Modern Experience, (Cambridge England: Cambridge University Press, 1991), 21-33.

${ }^{96}$ Irving Sandler, The Triumph of American Painting: A History of Abstract Expressionism (New York: Praeger, 1970), 96.

97 Stephen Polcari, Abstract Expressionism and the Modern Experience, (Cambridge England: Cambridge University Press, 1991), 23-87.

98 Douglas Burnham and George Papandreopuolos, "Existentialism," Internet Encylcopedia: A Peer-Reviewed Academic Resource, Accessed September 24, 2015, http://www.iep.utm.edu/existent/\#SH3a.

${ }^{99}$ Irving Sandler, The Triumph of American Painting: A History of Abstract Expressionism (New York: Praeger, 1970), 98.

100 Ibid, 3. 
${ }^{101}$ Irving Sandler, Abstract Expressionism and the American Experience: $A$ Reevaluation (New York: Hard Press Editions Inc, 2009), 19.

102 Irving Sandler, The Triumph of American Painting: A History of Abstract Expressionism (New York: Praeger, 1970), 148-154.

103 Wood, Paul, Modernism in Dispute : Art Since the Forties (New Haven: Yale University Press, 1993) 9-35. ; Stephen Polcari, Abstract Expressionism and the Modern Experience, (Cambridge England: Cambridge University Press, 1991), 4-16. ${ }^{104}$ Irving Sandler, From Avant-Garde to Pluralism: An On-The-Spot History (Lenox, MA: Hard Press Editions, 2006), 15. ; Irving Sandler, The New York School (New York: Harper and Row Publishers, 1978), 17.

105 Emily Genauer, “Still Life with Red Herring," Harper's Magazine September 1949, 89.

${ }^{106}$ Margaret Lynne Ausfeld, "Circus Girl Arrested: A History of the Advancing American Art Collection, 1946-1948," In Advancing American Art: Politics and Aesthetics in the State Department Exhibition, 1946-1948 (Montgomery: Montgomery Museum of Fine Arts, 1984), Exhibition Catalogue, 20.

${ }^{107}$ Francis Henry Taylor, "Modern Art and the Dignity of Man," Atlantic Monthly, December 1948, 30-31, 36.

108 Irving Sandler, Abstract Expressionism and the American Experience: A

Reevaluation (New York: Hard Press Editions Inc, 2009), 199.

${ }^{109}$ Paul Wood, Modernism in Dispute: Art Since the Forties (New Haven: Yale University Press, 1993) 9-32.

110 Irving Sandler, The New York School (New York: Harper and Row Publishers, 1978), $2-3,30$.

111 Irving Sandler, From Avant-Garde to Pluralism: An On-The-Spot History (Lenox, MA: Hard Press Editions, 2006), 237-248.

${ }^{112}$ Clement Greenberg, The Collected Essays and Criticism Volume IV: Modernism with a Vengeance 1957-1969, Edited by John O'Brian (Chicago: University of Chicago Press, 1993), 194-195.

113 Allan Kaprow, “Editor's Letters," Art News Volume 57, Number 10 (February 1959):

6.

114 Irving Sandler, The New York School (New York: Harper and Row Publishers, 1978), 16.

115 Paul Wood, Modernism in Dispute: Art Since the Forties (New Haven: Yale University Press, 1993) 53.

116 Irving Sandler, The New York School (New York: Harper and Row Publishers, 1978), 35.

117 Irving Sandler, The Triumph of American Painting: A History of Abstract Expressionism (New York: Praeger, 1970), 274.

118 Clement Greenberg, The Collected Essays and Criticism Volume IV: Modernism with a Vengeance 1957-1969, Edited by John O'Brian (Chicago: University of Chicago Press, 1993), 193, 124. ; Clement Greenberg, The Collected Essays and Criticism Volume I:

Perceptions and Judgements 1939-1944, Edited by John O'Brian (Chicago: University of Chicago Press, 1986), 8-9. 
${ }^{119}$ Clement Greenberg, The Collected Essays and Criticism Volume III: Affirmations and Refusals 1950-1956, Edited by John O'Brian (Chicago: University of Chicago Press, 1993), 226.

120 Clement Greenberg, The Collected Essays and Criticism Volume II: Arrogant Purpose 1945-1949, Edited by John O'Brian (Chicago: University of Chicago Press, 1986), 228-230.

${ }^{121}$ Clement Greenberg, The Collected Essays and Criticism Volume IV: Modernism with a Vengeance 1957-1969, Edited by John O'Brian (Chicago: University of Chicago Press, 1993), 71.

122 Ibid, 123.

123 Ibid, 96-97.

124 Ibid, 96-98, 131.

125 Ibid, 131-134.

126 Paul Wood, Modernism in Dispute: Art Since the Forties (New Haven: Yale University Press, 1993) 63.

127 Ann Eden Gibson, Abstract Expressionism: Other Politics (New Haven: Yale University Press, 1997), xxvii-xxvii.

128 Clement Greenberg, The Collected Essays and Criticism Volume IV: Modernism with a Vengeance 1957-1969, Edited by John O'Brian (Chicago: University of Chicago Press, 1993), 129.

129 Irving Sandler, The Triumph of American Painting: A History of Abstract Expressionism (New York: Praeger, 1970), 125.

${ }^{130}$ Clement Greenberg, The Collected Essays and Criticism Volume IV: Modernism with a Vengeance 1957-1969, Edited by John O'Brian (Chicago: University of Chicago Press, 1993), 131-134.

131 Irving Sandler, The Triumph of American Painting: A History of Abstract Expressionism (New York: Praeger, 1970), 130.

132 Elaine De Kooning, Rose Slivka and Marjorie Luyckx, The Spirit of Abstract Expressionism: Selected Writings (New York: George Braziller, 1994), 83, 67.

133 See Rosenberg, Harold. 1952. "The American Action Painters" in The Tradition of the New. London: Thames and Hud), 25.

134 Irving Sandler, From Avant-Garde to Pluralism: An On-The-Spot History (Lenox, MA: Hard Press Editions, 2006), 31.

135 Ibid, 66.

136 Elaine De Kooning, Rose Slivka and Marjorie Luyckx, The Spirit of Abstract Expressionism: Selected Writings (New York: George Braziller, 1994), 169.

${ }^{137}$ Clement Greenberg, The Collected Essays and Criticism Volume II: Arrogant Purpose 1945-1949, Edited by John O'Brian (Chicago: University of Chicago Press, 1986), 195. 138 Ibid, 223.

139 Irving Sandler, Abstract Expressionism and the American Experience: $A$ Reevaluation (New York: Hard Press Editions Inc, 2009), 115.

${ }^{140}$ Jeffrey Wechsler, Sam Hunter, Irving Sandler, William Seitz and Matthew Lee Rohn, Abstract Expressionism: Other Dimensions: An Introduction to Small Scale Painterly Abstraction in America, 1940-1965, (New Brunswick: Jane Voorhees Zimmerli Art Museum, Rutgers, 1989), Exhibition Catalogue, 35. 
141 Ibid, 35-58, 67, 77-80.

142 Ann Eden Gibson, Abstract Expressionism: Other Politics (New Haven: Yale University Press, 1997), 2-3.

143 Michael Leja, Reframing Abstract Expressionism (New Haven: Yale University Press, 1993), 257.

144 Irving Sandler, From Avant-Garde to Pluralism: An On-The-Spot History (Lenox, MA: Hard Press Editions, 2006), 31.

145 Irving Sandler, The Triumph of American Painting: A History of Abstract Expressionism (New York: Praeger, 1970), 3.

146 Harold Rosenberg, Discovering the Present: Three Decades in Art, Culture, and Politics (Chicago: University of Chicago Press, 1973), 106-107.

${ }^{147}$ Clement Greenberg, The Collected Essays and Criticism Volume II: Arrogant Purpose 1945-1949, Edited by John O'Brian (Chicago: University of Chicago Press, 1986), 87.

148 Irving Sandler, Abstract Expressionism and the American Experience: $A$

Reevaluation (New York: Hard Press Editions Inc, 2009), 221.

149 Michael Leja, Reframing Abstract Expressionism (New Haven: Yale University Press, 1993), 6, 256.

150 Irving Sandler, Abstract Expressionism and the American Experience: A

Reevaluation (New York: Hard Press Editions Inc, 2009), 222-223.

151 Ann Eden Gibson, Abstract Expressionism: Other Politics (New Haven: Yale

University Press, 1997), ix, xi, xxxiv, 154.

152 Irving Sandler, Abstract Expressionism and the American Experience: $A$

Reevaluation (New York: Hard Press Editions Inc, 2009), 25.

153 Robert Goodnough Ed., “Artists' Sessions at Studio 35 (1950)," In Modern Artists In

America, First Series, edited by Robert Motherwell and Ad Reinhardt, 8-23, (NewYork:

Wittenborn Schultz, 1950), 18.

154 Willem De Kooning, Thomas B. Hess and Museum of Modern Art, Willem De

Kooning (New York: Museum of Modern Art, 1969), Exhibition Catalogue, 45.

155 Whitney Museum of American Art, John I. H. Baur and Larry Aldrich, Lyrical

Abstraction (New York: Whitney Museum of American Art, 1971).

156 Elaine De Kooning. “Subject: What, How or Who?” Art News Volume 54, Number

2 (April 1955): 62.

157 Ann Eden Gibson, Abstract Expressionism: Other Politics (New Haven: Yale

University Press, 1997), 9.

158 Ibid.

${ }^{159}$ Clement Greenberg, The Collected Essays and Criticism Volume I: Perceptions and Judgements 1939-1944, Edited by John O’Brian (Chicago: University of Chicago Press, 1986), 205-206.

160 Irving Sandler, Abstract Expressionism and the American Experience: $A$

Reevaluation (New York: Hard Press Editions Inc, 2009), 222.

161 Michael Leja, Reframing Abstract Expressionism (New Haven: Yale University Press, 1993), 249.

162 Clement Greenberg, The Collected Essays and Criticism Volume II: Arrogant Purpose 1945-1949, Edited by John O'Brian (Chicago: University of Chicago Press, 1986), 326. 
163 Stephen Polcari, Abstract Expressionism and the Modern Experience (Cambridge England: Cambridge University Press, 1991), 38-49.

164 Irving Sandler, The New York School (New York: Harper and Row Publishers, 1978), 2.

165 Elaine De Kooning, Rose Slivka and Marjorie Luyckx, The Spirit of Abstract

Expressionism: Selected Writings (New York: George Braziller, 1994), 165.

166 Ibid, 21-22.

167 Irving Sandler, From Avant-Garde to Pluralism: An On-The-Spot History (Lenox, MA: Hard Press Editions, 2006), 20.

168 Lawrence Campbell, "Sally Hazelet Drummond Draft 5," ca. 1972, (Sally Hazelet Drummond Papers. In the possession of Sally Hazelet Drummond), 2. ; Hilton Kramer, "Art: Drummond Show at the Corcoran," The New York Times (New York, NY), November 24, 1972, (Sally Hazelet Drummond Papers. Alexandre Gallery).

${ }^{169}$ Fischbach Gallery, "Sally Hazelet Drummond," Fischbach Gallery, Press Release, 1968, (Sally Hazelet Drummond Papers. In the possession of Sally Hazelet Drummond). 170 Columbus Museum of Art, “Optic Nerve: Perceptual Art of the 1960s," Columbus Museum of Art, Columbus, Ohio, February 15, 2007, Exhibition Mailer (Sally Hazelet Drummond Papers. In the possession of Sally Hazelet Drummond).

171 Sally Hazelet Drummond, draft for speech for Cornell Art Gallery, Rollins College, Speech delivered September 25, 1989, multiple drafts (Sally Hazelet Drummond Papers. In the possession of Sally Hazelet Drummond). ; Whitney Museum of American Art, John I. H. Baur and Larry Aldrich. Lyrical Abstraction. New York: Whitney Museum of American Art, 1971. ; P.S. 1 Museum., "Abstract Painting: 1960-1969.," P.S. 1 Museum, Long Island City, New York, January 16 - March 13, 1983, Exhibition Brochure, (Sally Hazelet Drummond Papers. In the possession of Sally Hazelet Drummond).

172 Thomas B. Hess, "The Phony Crisis in American Art," Art News. Volume 62, Number 4, Summer 1963: 27-28.

${ }^{173}$ Artists Space, "Sally Hazelet Drummond," Artists Space, New York, New York, February 25 - March 24, 1984, Exhibition Brochure, (Artists’ Files, Sally Hazelet Drummond, University of Louisville Margaret M. Bridwell Art Library).

${ }^{174}$ Lawrence Campbell, "Sally Hazelet Drummond Draft 5," ca. 1972, (Sally Hazelet Drummond Papers. In the possession of Sally Hazelet Drummond).

175 Sally P. Hazelet. “A Commentary on my Painting," Master's Thesis (University of Louisville, 1952), 20, 14.

176 Sally Hazelet Drummond, artist's statement, ca. 1952, (Sally Hazelet Drummond Papers. In the possession of Sally Hazelet Drummond).

177 Ian Chilvers Ed., The Oxford Dictionary of Art, Third Edition, (Oxford: Oxford University Press, 2004), 505.

178 Tate Museum, "Non-Objective Art," Tate, Accessed September 24, 2015, http://www.tate.org.uk/learn/online-resources/glossary/n/non-objective-art. 179 Hilton Kramer, "Taste and Talent for the Extravagant," The New York Times (New York, NY), Undated, (Sally Hazelet Drummond Papers. In the possession of Sally Hazelet Drummond).

180 Sally P. Hazelet. “A Commentary on my Painting," Master's Thesis (University of Louisville, 1952), 7. 
181 Hazelet, Sally P. "World of Silent Painting." Arts in Louisville. Number Ten, Volume Two. September, 1957.

182 Sally Hazelet Drummond, draft for speech for Cornell Art Gallery, Rollins College, Speech delivered September 25, 1989, multiple drafts (Sally Hazelet Drummond Papers. In the possession of Sally Hazelet Drummond).

183 Ibid.

184 Hazelet, Sally P. "World of Silent Painting." Arts in Louisville. Number Ten, Volume Two. September, 1957.

185 Sarah Lansdell, "American Art Then and Now at Speed," Courier-Journal (Louisville, KY), May 7, 1967, (Sally Hazelet Drummond Papers. In the possession of Sally Hazelet Drummond).

186 Diane Heilenman, "Sally Drummond Returning," Courier-Journal (Louisville, KY), January 21, 1990, (Sally Hazelet Drummond Papers. In the possession of Sally Hazelet Drummond).

${ }^{187}$ Dore Ashton, "Art: Ornamental Forms: Work of Ron Gorchov at Tibor de Nagy Suggests Aspects of All Cultures," Unknown Source, Undated, (Sally Hazelet Drummond Papers. In the possession of Sally Hazelet Drummond).

188 The Corcoran Gallery of Art, "Sally Hazelet Drummond Retrospective," The Corcoran Gallery of Art, Washington, D.C., November 3 - December 3, 1972, Exhibition Brochure, (Sally Hazelet Drummond Papers. In the possession of Sally Hazelet Drummond).

189 Sally Hazelet Drummond, "Sally Drummond: Painting Indra's Net," Interview by Sparrow, Undated, (Sally Hazelet Drummond Papers. In the possession of Sally Hazelet Drummond).

190 Irving Sandler, The New York School (New York: Harper and Row Publishers, 1978), 236.

191 Sally Hazelet Drummond, artist's statement, ca. 1965, (Sally Hazelet Drummond Papers. In the possession of Sally Hazelet Drummond). ; Sally Hazelet Drummond, Sally Hazelet Drummond in discussion with the author, July 25, 2015, Germantown, New York, See Addendum of Hillary Sullivan's Master's Thesis, University of Louisville, 71, 16. ; Sally Hazelet Drummond, draft for speech for Cornell Art Gallery, Rollins College, Speech delivered September 25, 1989, multiple drafts (Sally Hazelet Drummond Papers. In the possession of Sally Hazelet Drummond).

192 Irving Sandler, The New York School, (New York: Harper and Row Publishers, 1978), 236. ; Lawrence Campbell, "Sally Hazelet Drummond Draft 5," ca. 1972, (Sally Hazelet Drummond Papers. In the possession of Sally Hazelet Drummond). 193 Sally Hazelet Drummond, draft for speech for Cornell Art Gallery, Rollins College, Speech delivered September 25, 1989, multiple drafts (Sally Hazelet Drummond Papers. In the possession of Sally Hazelet Drummond).

194 Thomas B., "The Phony Crisis in American Art," Art News, Volume 62, Number 4, Summer 1963: 24-28, 59-60.

${ }^{195}$ Sally Hazelet Drummond, curriculum vitae, Undated, multiple copies, (Sally Hazelet Drummond Papers. In the possession of Sally Hazelet Drummond). ; Sally Hazelet Drummond, "Sally Hazelet Drummond," [curriculum vitae], Undated, (Alexandre Gallery). 
196 Sally Hazelet Drummond, draft for speech for Cornell Art Gallery, Rollins College, Speech delivered September 25, 1989, multiple drafts (Sally Hazelet Drummond Papers. In the possession of Sally Hazelet Drummond).

197 Hazelet, Sally P. "World of Silent Painting." Arts in Louisville. Number Ten, Volume Two. September, 1957.

198 Maurice Poirier and Jane Necol, "The '60s in Abstract: 13 Statements and an Essay,” Art in America, October 1983, 126.

199 Sally Hazelet Drummond, draft for speech for Cornell Art Gallery, Rollins College, Speech delivered September 25, 1989, multiple drafts (Sally Hazelet Drummond Papers. In the possession of Sally Hazelet Drummond).

200 Sally Hazelet Drummond, "Sally Drummond: Painting Indra's Net," Interview by Sparrow, Undated, (Sally Hazelet Drummond Papers. In the possession of Sally Hazelet Drummond).

201 Sally P. Hazelet. “A Commentary on my Painting," Master's Thesis (University of Louisville, 1952), 21-24.

202 Maurice Poirier and Jane Necol, "The '60s in Abstract: 13 Statements and an Essay," Art in America, October 1983, 126.

203 Sally Hazelet Drummond, draft for speech for Cornell Art Gallery, Rollins College, Speech delivered September 25, 1989, multiple drafts (Sally Hazelet Drummond Papers. In the possession of Sally Hazelet Drummond).

204 Linette Burton, "Dots Intrigue Sally Drummond," Ridgefield Press (Ridgefield, CT), January 18, 1979, (Sally Hazelet Drummond Papers. In the possession of Sally Hazelet Drummond). ; Joan Kay, "Speed Exhibit Draws Artists Home," Courier-Journal (Louisville, KY), May 9, 1967, (Sally Hazelet Drummond Papers. In the possession of Sally Hazelet Drummond).

205 The Corcoran Gallery of Art, "Sally Hazelet Drummond Retrospective," The Corcoran Gallery of Art, Washington, D.C., November 3 - December 3, 1972, Exhibition Brochure, (Sally Hazelet Drummond Papers. In the possession of Sally Hazelet Drummond).

206 Martha B. Scott, “Aldrich Museum of Contemporary Art/ Ridgefield; Sally Hazelet Drummond," Art New England Volume II, Number 4, March 1981, (Sally Hazelet Drummond Papers. In the possession of Sally Hazelet Drummond).

207 The Corcoran Gallery of Art, "Sally Hazelet Drummond Retrospective," The Corcoran Gallery of Art, Washington, D.C., November 3 - December 3, 1972, Exhibition Brochure, (Sally Hazelet Drummond Papers. In the possession of Sally Hazelet Drummond). ; Museum of Modern Art, "Recent Acquisitions," Museum of Modern Art, New York, New York, November 20, 1962 - January 13, 1963, Exhibition Checklist, (Sally Hazelet Drummond Papers. In the possession of Sally Hazelet Drummond). 208 Martha B. Scott, "Sun Spots and Sun-Streaked Horizons Glow from Walls," Bridgeport Sunday Post (Bridgeport, CT), July 20, 1980, (Sally Hazelet Drummond Papers. In the possession of Sally Hazelet Drummond).

209 The Corcoran Gallery of Art, "Sally Hazelet Drummond Retrospective," The Corcoran Gallery of Art, Washington, D.C., November 3 - December 3, 1972, Exhibition Brochure, (Sally Hazelet Drummond Papers. In the possession of Sally Hazelet Drummond). 
${ }^{210}$ Hilton Kramer, "Art: Drummond Show at the Corcoran," The New York Times (New York, NY), November 24, 1972, (Sally Hazelet Drummond Papers. Alexandre Gallery). ${ }^{211}$ Sally Hazelet Drummond, draft for speech for Cornell Art Gallery, Rollins College, Speech delivered September 25, 1989, multiple drafts (Sally Hazelet Drummond Papers. In the possession of Sally Hazelet Drummond).

${ }^{212}$ Hazelet, Sally P. "World of Silent Painting." Arts in Louisville. Number Ten, Volume Two. September, 1957.

213 Sally Hazelet Drummond, Sally Hazelet Drummond in discussion with the author, July 25, 2015, Germantown, New York, See Addendum of Hillary Sullivan's Master's Thesis, University of Louisville, 13-14.

${ }^{214}$ Sally Hazelet Drummond, draft for speech for Cornell Art Gallery, Rollins College, Speech delivered September 25, 1989, multiple drafts (Sally Hazelet Drummond Papers. In the possession of Sally Hazelet Drummond).

215 Ronald Bladen, Lois Dodd, Sally Hazelet Drummond, Al Held, Alex Katz, William King, Philip Pearlstein and George Sugarman, Eight Begin: Artists' Memories of Starting Out, Edited by Ada Katz, (Waterville: Colby Museum of Art, 2014), 14. ${ }^{216}$ Maurice Poirier and Jane Necol, "The '60s in Abstract: 13 Statements and an Essay," Art in America, October 1983, 126.

217 Sally Hazelet Drummond, draft for speech for Cornell Art Gallery, Rollins College, Speech delivered September 25, 1989, multiple drafts (Sally Hazelet Drummond Papers. In the possession of Sally Hazelet Drummond).

218 Ibid.

${ }^{219}$ Harry Shaw, “The Painting is 'Silent,' but Viewers Aren't," Courier-Journal (Louisville, KY), November 17, 1957, (Sally Hazelet Drummond Papers. In the possession of Sally Hazelet Drummond).

${ }^{220}$ Sally Hazelet Drummond, "Sally Drummond: Painting Indra's Net," Interview by Sparrow, Undated, (Sally Hazelet Drummond Papers. In the possession of Sally Hazelet Drummond).

${ }^{221}$ Artists Space, "Sally Hazelet Drummond," Artists Space, New York, New York, February 25 - March 24, 1984, Exhibition Brochure, (Artists' Files, Sally Hazelet Drummond, University of Louisville Margaret M. Bridwell Art Library). ; Alexandre Gallery, "Sally Hazelet Drummond." Alexandregallery.com. http://www.alexandregallery.com/sally-hazelet-drummond.

${ }^{222}$ Sally P. Hazelet, "World of Silent Painting," Arts in Louisville, Number Ten, Volume Two, September, 1957.

${ }^{223}$ Tanager Gallery, "The Private Myth," Tanager Gallery, New York, New York, October 6 - 26, 1961, Exhibition Brochure, (Sally Hazelet Drummond Papers. In the possession of Sally Hazelet Drummond).

${ }^{224}$ Sally Hazelet Drummond, artist's statement, ca. 1965, (Sally Hazelet Drummond Papers. In the possession of Sally Hazelet Drummond).

${ }^{225}$ Sally Hazelet Drummond, draft for speech for Cornell Art Gallery, Rollins College, Speech delivered September 25, 1989, multiple drafts (Sally Hazelet Drummond Papers. In the possession of Sally Hazelet Drummond). 
226 Sally Hazelet Drummond, Sally Hazelet Drummond in discussion with the author, July 25, 2015, Germantown, New York, See Addendum of Hillary Sullivan's Master's Thesis, University of Louisville, 25.

227 Ibid, 33.

${ }^{228}$ Sally Hazelet Drummond, Sally Hazelet Drummond to Erik La Prade. October 9, 2009, (Sally Hazelet Drummond Papers. In the possession of Sally Hazelet Drummond), 3.

${ }^{229}$ Sally Hazelet Drummond, Sally Hazelet Drummond to Cindy Nemser, 1979, (Sally Hazelet Drummond Papers. In the possession of Sally Hazelet Drummond).

${ }^{230}$ Sally Hazelet Drummond, Sally Hazelet Drummond in discussion with the author, July 25, 2015, Germantown, New York, See Addendum of Hillary Sullivan's Master's Thesis, University of Louisville, 34-35. ; Sally Hazelet Drummond, Sally Hazelet Drummond to Erik La Prade. October 9, 2009, (Sally Hazelet Drummond Papers. In the possession of Sally Hazelet Drummond), 3.

232 Housatonic Community College, "American Women Painters," Housatonic Community College, Bridgeport, Connecticut, October 3 - 28, 1976, (Sally Hazelet Drummond Papers. In the possession of Sally Hazelet Drummond).

233 Mitchell Algus Gallery, "Sally Hazelet Drummond: Paintings 1960-2000," Mitchell Algus Gallery, New York, New York, October 18 - November 15, 2003, Exhibition Price List and Press Release, (Sally Hazelet Drummond Papers. In the possession of Sally Hazelet Drummond).

${ }^{234}$ George Ellis Burcaw, Introduction to Museum Work, 3rd Edition, American Association for State and Local History Book Series, (Walnut Creek: Altamira Press, 1997), 129.

${ }^{235}$ Lisa C. Roberts, From Knowledge to Narrative: Educators and the Changing Museum, (Washington D.C.: Smithsonian Institution Press, 1997), 8.

${ }^{236}$ University of Louisville, "About the University of Louisville," University of Louisville, Accessed October 5th, 2015, http://louisville.edu/about/.

${ }^{237}$ University of Louisville and Hite Art Institute. "The Hite Art Institute, Department of Fine Arts." Univeristy of Louisville. Accessed October $5^{\text {th }}, 2015$.

http://louisville.edu/art/about.

238 George Ellis Burcaw, Introduction to Museum Work, 3rd Edition, American Association for State and Local History Book Series, (Walnut Creek: Altamira Press, 1997), 132.

${ }^{239}$ Sally Hazelet Drummond, Sally Hazelet Drummond in discussion with the author, July 25, 2015, Germantown, New York, See Addendum of Hillary Sullivan's Master's Thesis, University of Louisville, 18-20. ; Harry Shaw, "The Painting is 'Silent,' but Viewers Aren't," Courier-Journal (Louisville, KY), November 17, 1957, (Sally Hazelet Drummond Papers. In the possession of Sally Hazelet Drummond).

${ }^{240}$ George Ellis Burcaw, Introduction to Museum Work, 3rd Edition, American Association for State and Local History Book Series, (Walnut Creek: Altamira Press, 1997), 122.

${ }^{241}$ Ibid, 154.

${ }^{242}$ Andre McClellan Ed., Art and Its Publics: Museum Studies at the Millennium (Malden: Blackwell Publishing, 2003), XVII. 
${ }^{243}$ John Cotton Dana, "The Gloom of the Museum," In Reinventing the Museum: The Evolving Conversation on the Paradigm Shift, Second Edition, Edited by Gail Anderson (Lanham: Alta Mira Press, 2012): 17-33.

${ }^{244}$ John Falk, and Lynn Dierking, The Museum Experience (Washington: Whalesback Books, 1992).

${ }^{245}$ George Ellis Burcaw, Introduction to Museum Work, 3rd Edition, American Association for State and Local History Book Series, (Walnut Creek: Altamira Press, 1997), 132-133.

246 "'Swinging' Exhibit: Jazz Music Backgrounds Abstract Paintings in Muskegon's Hackley Gallery," Grand Rapids Press (Grand Rapids, MI), November 11, 1962 (Sally Hazelet Drummond Papers. In the possession of Sally Hazelet Drummond).

${ }^{247}$ Lisa C. Roberts, From Knowledge to Narrative: Educators and the Changing Museum (Washington D.C.: Smithsonian Institution Press, 1997), 32.

${ }^{248}$ George Ellis Burcaw, Introduction to Museum Work, 3rd Edition, American Association for State and Local History Book Series, (Walnut Creek: Altamira Press, 1997), 155.

${ }^{249}$ Ibid, 132.

${ }^{250}$ Lisa C. Roberts, From Knowledge to Narrative: Educators and the Changing Museum (Washington D.C.: Smithsonian Institution Press, 1997), 67.

${ }^{251}$ Beverly Serrell, Exhibit Labels: An Interpretive Approach, (Walnut Creek: Alta Mira Press, 1996), 27.

252 Metropolitan Museum of Art and American Association of Museums, Standards Manual for Signs and Labels: 1995, Professional Practice Series, 1995, Reprint, (Washington: Technical Information Service, 2005), 16, 31.

253 Beverly Serrell, Exhibit Labels: An Interpretive Approach (Walnut Creek: Alta Mira Press, 1996), 33.

${ }^{254}$ David Dean, Museum Exhibition: Theory and Practice (The Heritage; Heritage. London: Routledge, 1994), 57.

255 Sally Hazelet Drummond, curriculum vitae, Undated, multiple copies, (Sally Hazelet Drummond Papers. In the possession of Sally Hazelet Drummond).; Sally Hazelet Drummond, "Sally Hazelet Drummond" [curriculum vitae], Undated, (Alexandre Gallery). This was also determined by going through the artist's papers and noting dates.

${ }^{256}$ Andre McClellan Ed., Art and Its Publics: Museum Studies at the Millennium (Malden: Blackwell Publishing, 2003), 21.

257 Sally Hazelet Drummond, Sally Hazelet Drummond in discussion with the author, July 25, 2015, Germantown, New York, See Addendum of Hillary Sullivan's Master's Thesis, University of Louisville, 15-16.

${ }^{258}$ Beverly Serrell, Judging Exhibitions: A Framework for Assessing Excellence (Walnut Creek: Left Coast Press, 2006).

${ }^{259}$ Artists Space, "Sally Hazelet Drummond," Artists Space, New York, New York, February 25 - March 24, 1984, Exhibition Brochure, (Artists' Files, Sally Hazelet Drummond, University of Louisville Margaret M. Bridwell Art Library). ${ }^{260}$ Irving Sandler, From Avant-Garde to Pluralism: An On-The-Spot History (Lenox, MA: Hard Press Editions, 2006),15. 
${ }^{261}$ Ann Eden Gibson, abstract of proposed session, "Abstract Expressionism's Others," 1990 Annual Meeting - Art History Sessions Announcement and Call for Papers, New York, College Art Association, 1989, 10.

${ }^{262}$ Ann Eden Gibson, Abstract Expressionism: Other Politics (New Haven: Yale University Press, 1997), xix-xxxvii.

${ }^{263}$ Michael Brenson, "Art: 12 Artists Shown in 'Underknown." Unknown Source, October 26, 1984, (Sally Hazelet Drummond Papers. In the possession of Sally Hazelet Drummond).

264 Thomas Micchelli, "The Anti-Expressionist: Jack Tworkov's Paradigm Shift," Hyperallergic, September 5, 2015, http://hyperallergic.com/234367/the-antiexpressionist-jack-tworkovs-paradigm-shift/.

265 Steinhauer, Jillian. "Finally, an Exhibition Devoted to the Women of Abstract Expressionism." Hyperallergic, September 24,

2015. http://hyperallergic.com/239282/finally-an-exhibition-devoted-to-the-women-ofabstract-expressionism/. 


\section{APPENDIX A}

WORKS CITED

Alexandre Gallery. "Sally Hazelet Drummond: Selected Paintings." Alexandre Gallery, New York, New York. October 27 - November 26, 2005. Press Release, October 2005 and Exhibition Brochure. Artist's File, Sally Hazelet Drummond, Alexandre Gallery.

-"Sally Hazelet Drummond.” Alexandregallery.com. http://www.alexandregallery.com/sally-hazelet-drummond.

“Among Painters in New York Number Sally Hazelet As One." Courier-Journal (Louisville, KY), January 11, 1959. Artists’ Files, Sally Hazelet Drummond, Main Branch, Louisville Free Public Library.

Art Center Association. "Ulfert Wilke” Art Center Association, Louisville, Kentucky. Undated. Biography, Chronology and Curatorial Statement. Artists' Files, Ulfert Wilke, University of Louisville Margaret M. Bridwell Art Library.

Art Center Gallery. "Sally Hazelet.” Art Center Gallery, Louisville, Kentucky. November 14 - December 6, 1957. Exhibition Brochure. Artists' Files, Sally Hazelet Drummond, University of Louisville Margaret M. Bridwell Art Library.

Artists Space. "Sally Hazelet Drummond.” Artists Space, New York, New York. February 25 - March 24, 1984. Exhibition Brochure. Artists' Files, Sally Hazelet Drummond, University of Louisville Margaret M. Bridwell Art Library.

-“Sally Hazelet Drummond: Paintings, 1971-84.” Artists Space. Press Release, February 1984. Sally Hazelet Drummond Papers. In the possession of Sally Hazelet Drummond.

Ashton, Dore. "Art: Ornamental Forms: Work of Ron Gorchov at Tibor de Nagy Suggests Aspects of All Cultures." Unknown Source. Undated. Sally Hazelet Drummond Papers. In the possession of Sally Hazelet Drummond.

Ausfeld, Margaret Lynne. "Circus Girl Arrested: A History of the Advancing American Art Collection, 1946-1948." In Advancing American Art: Politics and Aesthetics in the State Department Exhibition, 1946-1948. Montgomery: Montgomery Museum of Fine Arts, 1984. Exhibition Catalogue.

Bard, Joellen, Pleiades Gallery, Association of Artist-Run Galleries, Amos Eno Gallery, Dore Ashton, Bruno Palmer-Poroner, Lawrence Alloway. Tenth Street Days: The Co-ops of the 50's: The Galleries: Tanager, Hansa, James, Camino, March, 
Brata, Phoenix, Area. New York: Education, Art \& Services Inc., 1977.

Exhibition Catalogue.

Bladen, Ronald, Lois Dodd, Sally Hazelet Drummond, Al Held, Alex Katz, William King, Philip Pearlstein and George Sugarman. Eight Begin: Artists' Memories of Starting Out, Edited by Ada Katz. Waterville: Colby Museum of Art, 2014.

Brenson, Michael. "Art: 12 Artists Shown in 'Underknown." Unknown Source, October 26, 1984. Sally Hazelet Drummond Papers. In the possession of Sally Hazelet Drummond.

Burcaw, George Ellis. Introduction to Museum Work. 3rd Edition. American Association for State and Local History Book Series. Walnut Creek: Altamira Press, 1997.

Burnham, Douglas and George Papandreopuolos. "Existentialism." Internet Encylcopedia: A Peer-Reviewed Academic Resource. Accessed September 24, 2015. http://www.iep.utm.edu/existent/\#SH3a.

Burton, Linette. "Drummonds Play and Paint in New Home on Wilton Road." October 24, 1963. Sally Hazelet Drummond Papers. In the possession of Sally Hazelet Drummond.

-“Dots Intrigue Sally Drummond.” Ridgefield Press (Ridgefield, CT), January 18, 1979. Sally Hazelet Drummond Papers. In the possession of Sally Hazelet Drummond.

Campbell, Lawrence. "Sally Hazelet Drummond Draft 5.” ca. 1972. Sally Hazelet Drummond Papers. In the possession of Sally Hazelet Drummond.

Chilvers, Ian Ed. The Oxford Dictionary of Art. Third Edition. Oxford: Oxford University Press, 2004.

Columbus Museum of Art. "Optic Nerve: Perceptual Art of the 1960s." Columbus Museum of Art, Columbus, Ohio. February 15, 2007. Exhibition Mailer. Sally Hazelet Drummond Papers. In the possession of Sally Hazelet Drummond.

The Corcoran Gallery of Art. "Sally Hazelet Drummond Retrospective." The Corcoran Gallery of Art, Washington, D.C.. November 3 - December 3, 1972. Exhibition Brochure. Sally Hazelet Drummond Papers. In the possession of Sally Hazelet Drummond.

The Cornell Fine Arts Museum. " Sally Hazelet Drummond.” Rollins College, Winter Park, Florida. September 8 - October 15, 1989. Exhibition Mailer and Brochure. Sally Hazelet Drummond Papers. In the possession of Sally Hazelet Drummond. 
Crosby, Thomas. “Art with a Punch.” Star-News (Unknown). ca. 1972. Sally Hazelet Drummond Papers. In the possession of Sally Hazelet Drummond.

Dana, John Cotton. "The Gloom of the Museum." In Reinventing the Museum: The Evolving Conversation on the Paradigm Shift, Second Edition. Edited by Gail Anderson. Lanham: Alta Mira Press, 2012: 17-33.

Dean, David. Museum Exhibition : Theory and Practice. The Heritage; Heritage. London: Routledge, 1994.

De Kooning, Elaine. "Subject: What, How or Who?" Art News Volume 54, Number 2 (April 1955): 29, 61-62.

De Kooning, Elaine, Rose Slivka and Marjorie Luyckx. The Spirit of Abstract Expressionism : Selected Writings. New York: George Braziller, 1994.

De Kooning, Willem, Thomas B. Hess and Museum of Modern Art. Willem De Kooning. New York: Museum of Modern Art, 1969. Exhibition Catalogue.

Drummond, Sally Hazelet. artist's statement. ca. 1952. Sally Hazelet Drummond Papers. In the possession of Sally Hazelet Drummond.

-artist's statement. ca. 1965. Sally Hazelet Drummond Papers. In the possession of Sally Hazelet Drummond.

-Sally Hazelet Drummond to Cindy Nemser. 1979. Sally Hazelet Drummond Papers. In the possession of Sally Hazelet Drummond.

-draft for speech for Cornell Art Gallery, Rollins College. Speech delivered September 25, 1989, multiple drafts. Sally Hazelet Drummond Papers. In the possession of Sally Hazelet Drummond.

- “Sally Hazelet Drummond." Interview by Erik La Prade. 2009. Transcript. Sally Hazelet Drummond Papers. In the possession of Sally Hazelet Drummond.

-Sally Hazelet Drummond in discussion with the author. July 25, 2015. Germantown, New York. See Addendum of Hillary Sullivan's Master's Thesis, University of Louisville.

-curriculum vitae. Undated, multiple copies. Sally Hazelet Drummond Papers. In the possession of Sally Hazelet Drummond.

-newspaper clippings. Undated. Sally Hazelet Drummond Papers. In the possession of Sally Hazelet Drummond. 
-"Sally Hazelet Drummond" [curriculum vitae]. Undated. Alexandre Gallery.

-“Sally Drummond: Painting Indra's Net.” Interview by Sparrow. Undated. Sally Hazelet Drummond Papers. In the possession of Sally Hazelet Drummond.

Falk, John and Dierking, Lynn. The Museum Experience. Washington: Whalesback Books, 1992.

Fischbach Gallery. "Sally Hazelet Drummond.” Fischbach Gallery. Press Release, 1968. Sally Hazelet Drummond Papers. In the possession of Sally Hazelet Drummond.

-"Sally Hazelet Drummond." Fischbach Gallery, New York, New York. April 22 May 17, 1972. Exhibition Brochure. Sally Hazelet Drummond Papers. In the possession of Sally Hazelet Drummond.

-“Sally Hazelet Drummond." Fischbach Gallery, New York, New York. November 18 - December 6, 1978. Exhibition Brochure. Sally Hazelet Drummond Papers. In the possession of Sally Hazelet Drummond.

Forgery, Benjamin. "The Art Galleries." The Evening Star and Daily News (Washington, D.C.), November 15, 1972. Sally Hazelet Drummond Papers. In the possession of Sally Hazelet Drummond.

Genauer, Emily. “Still Life with Red Herring.” Harper’s Magazine September 1949.

Gibson, Ann Eden. abstract of proposed session. "Abstract Expressionism's Others." 1990 Annual Meeting - Art History Sessions Announcement and Call for Papers. New York, College Art Association, 1989.

-Abstract Expressionism: Other Politics. New Haven: Yale University Press, 1997.

Goodnough, Robert Ed., “Artists' Sessions at Studio 35 (1950).” In Modern Artists In America, First Series, edited by Robert Motherwell and Ad Reinhardt, 8-23. New York: Wittenborn Schultz, 1950.

Goosen, E.C.. "Rothko: The Omnibus Image." Art News Volume 59, Number 9 (January 1961): 37-39, 60-61.

Greenberg, Clement. Art and Culture. 1961, Reprint Boston: Beacon Press, 1989.

-The Collected Essays and Criticism Volume I: Perceptions and Judgements 1939-1944. Edited by John O’Brian. Chicago: University of Chicago Press, 1986. 
-The Collected Essays and Criticism Volume II: Arrogant Purpose 1945-1949. Edited by John O’Brian. Chicago: University of Chicago Press, 1986.

-The Collected Essays and Criticism Volume III: Affirmations and Refusals 19501956. Edited by John O’Brian. Chicago: University of Chicago Press, 1993.

-The Collected Essays and Criticism Volume IV: Modernism with a Vengeance 1957-1969. Edited by John O’Brian. Chicago: University of Chicago Press, 1993.

-Clement Greenberg: Late Writings. Edited by Robert C. Morgan. Minneapolis: University of Minnesota Press, 2003.

Hazelet, Sally P. “A Commentary on my Painting," Master's Thesis, University of Louisville, 1952.

-"World of Silent Painting." Arts in Louisville. Number Ten, Volume Two. September, 1957.

Heilenman, Diane. "Sally Drummond Returning." Courier-Journal (Louisville, KY), January 21, 1990. Sally Hazelet Drummond Papers. In the possession of Sally Hazelet Drummond.

Hess, Thomas B. "The Phony Crisis in American Art." Art News. Volume 62, Number 4. Summer 1963: 24-28, 59-60.

Housatonic Community College. "American Women Painters.” Housatonic Community College, Bridgeport, Connecticut. October 3 - 28, 1976. Sally Hazelet Drummond Papers. In the possession of Sally Hazelet Drummond.

Kaprow, Allan. "Editor's Letters.” Art News Volume 57, Number 10 (February 1959): 6.

Kay, Joan. "Speed Exhibit Draws Artists Home." Courier-Journal (Louisville, KY), May 9, 1967. Sally Hazelet Drummond Papers. In the possession of Sally Hazelet Drummond.

-“Saturday Wedding Calls Family Home.” Courier-Journal (Louisville, KY), June 26, 1968. Sally Hazelet Drummond Papers. In the possession of Sally Hazelet Drummond.

Kramer, Hilton. "Art: Drummond Show at the Corcoran." The New York Times (New York, NY), November 24, 1972. Sally Hazelet Drummond Papers. Alexandre Gallery.

-“Taste and Talent for the Extravagant." The New York Times (New York, NY). 
Undated. Sally Hazelet Drummond Papers. In the possession of Sally Hazelet Drummond.

Landau, Ellen G. Reading Abstract Expressionism: Context and Critique. New Haven: Yale University Press, 2005.

Lansdell, Sarah. "American Art Then and Now at Speed." Courier-Journal (Louisville, KY), May 7, 1967. Sally Hazelet Drummond Papers. In the possession of Sally Hazelet Drummond.

Leja, Michael. Reframing Abstract Expressionism. New Haven: Yale University Press, 1993.

Leonard, Elizabeth. "To Spend Year in France: Guggenheim for Artist." Ridgefield Area News (Ridgefield, CT), April 3, 1967. Sally Hazelet Drummond Papers. In the possession of Sally Hazelet Drummond.

McClellan, Andre Ed.. Art and Its Publics: Museum Studies at the Millennium. Malden: Blackwell Publishing, 2003.

Metropolitan Museum of Art and American Association of Museums. Standards Manual for Signs and Labels: 1995. Professional Practice Series. 1995. Reprint, Washington: Technical Information Service, 2005.

Micchelli, Thomas. "The Anti-Expressionist: Jack Tworkov's Paradigm Shift.” Hyperallergic, September 5, 2015. http://hyperallergic.com/234367/the-antiexpressionist-jack-tworkovs-paradigm-shift/.

Mitchell Algus Gallery. "Sally Hazelet Drummond: Paintings 1960-2000.” Mitchell Algus Gallery, New York, New York. October 18 - November 15, 2003.

Exhibition Brochure. Artists’ File, Sally Hazelet Drummond, Alexandre Gallery.

-“Sally Hazelet Drummond: Paintings 1960-2000.” Mitchell Algus Gallery, New York, New York. October 18 - November 15, 2003. Exhibition Price List and Press Release. Sally Hazelet Drummond Papers. In the possession of Sally Hazelet Drummond.

Motherwell, Robert., Dore. Ashton, Jack D. Flam, Robert T. Buck, and Albright-Knox Art Gallery. Robert Motherwell. New York: Abbeville Press, 1983. Exhibition Catalogue.

Museum of Modern Art. The New American Paintings As Shown in Eight European Countries, 1958-1959. New York: Museum of Modern Art, 1959.

-“Recent Acquisitions.” Museum of Modern Art, New York, 
New York. November 20, 1962 - January 13, 1963. Exhibition Checklist. Sally Hazelet Drummond Papers. In the possession of Sally Hazelet Drummond.

-“Cubism,” Museum of Modern Art Learning, Accessed September 24, 2015, https://www.moma.org/learn/moma_learning/themes/cubism.

-“German Expressionism,” Museum of Modern Art, Accessed September 24, 2015, http://www.moma.org/explore/collection/ge/styles/index.

-“Surrealism.” Museum of Modern Art Learning. Accessed September 24, 2015. https://www.moma.org/learn/moma_learning/themes/surrealism.

Poirier, Maurice and Jane Necol. "The '60s in Abstract: 13 Statements and an Essay." Art in America, October 1983: 122-137.

Polcari, Stephen. Abstract Expressionism and the Modern Experience. Cambridge England: Cambridge University Press, 1991.

P.S. 1 Museum. “Abstract Painting: 1960-1969.” P.S. 1 Museum, Long Island City, New York. January 16 - March 13, 1983. Exhibition Brochure. Sally Hazelet Drummond Papers. In the possession of Sally Hazelet Drummond.

Ramey, Lorrie Kyle. “An Illustrated Life.” In Rollins Alumni Record. Winter 1990, 2728. Sally Hazelet Drummond Papers. In the possession of Sally Hazelet Drummond.

Richard, Paul. "Corcoran Combatants Seek Peace." The Washington Post (Washington, D.C.), November 5, 1972. Sally Hazelet Drummond Papers. In the possession of Sally Hazelet Drummond.

-“Raising the Corcoran Question.” Unknown Source. Undated. Sally Hazelet Drummond Papers. In the possession of Sally Hazelet Drummond.

Roberts, Lisa C.. From Knowledge to Narrative: Educators and the Changing Museum. Washington D.C.: Smithsonian Institution Press, 1997.

Rosenberg, Harold. The Tradition of the New. New York: Horizon Press, 1959.

-Discovering the Present: Three Decades in Art, Culture, and Politics. Chicago: University of Chicago Press, 1973.

Sandler, Irving. The Triumph of American Painting: A History of Abstract Expressionism. New York: Praeger, 1970.

- The New York School. New York: Harper and Row Publishers, 1978. 
-From Avant-Garde to Pluralism: An On-The-Spot History. Lenox, MA:

Hard Press Editions, 2006.

-Abstract Expressionism and the American Experience: A Reevaluation. New York: Hard Press Editions Inc, 2009.

Scott, Martha B. "Sun Spots and Sun-Streaked Horizons Glow from Walls." Bridgeport Sunday Post (Bridgeport, CT), July 20, 1980. Sally Hazelet Drummond Papers. In the possession of Sally Hazelet Drummond.

-“Aldrich Museum of Contemporary Art/ Ridgefield; Sally Hazelet

Drummond.” Art New England Volume II, Number 4. March 1981. Sally Hazelet Drummond Papers. In the possession of Sally Hazelet Drummond.

Scott, Sue, Gerald Nordland and Orlando Museum of Art. Washington Color Painters: The First Generation: Gene Davis, Thomas Downing, Morris Louis, Howard Mehring, Kenneth Noland. Orlando: Orlando Museum of Art, 1990. Exhibition Catalogue.

Serrell, Beverly. Exhibit Labels: An Interpretive Approach. Walnut Creek: Alta Mira Press, 1996.

-Judging Exhibitions: A Framework for Assessing Excellence. Walnut Creek: Left Coast Press, 2006.

Seuphor, Michel, Lionel Izod, John Montague and Francis Scarfe. Dictionary of Abstract Painting with a History of Abstract Painting. New York: Tudor Publishing Company, 1957.

Shaw, Harry. "The Painting is 'Silent,' but Viewers Aren't." Courier-Journal (Louisville, KY), November 17, 1957. Sally Hazelet Drummond Papers. In the possession of Sally Hazelet Drummond.

Smith, Roberta. "Richard Bellamy, Art Dealer, Is Dead at 70." The New York Times (New York, NY), April 3, 1998. http://www.nytimes.com/1998/04/03/arts/richard-bellamy-art-dealer-is-dead-at70.html.

"'Swinging' Exhibit: Jazz Music Backgrounds Abstract Paintings in Muskegon's Hackley Gallery." Grand Rapids Press (Grand Rapids, MI), November 11, 1962. Sally Hazelet Drummond Papers. In the possession of Sally Hazelet Drummond. 
Tanager Gallery. “The Private Myth.” Tanager Gallery, New York, New York. October 6 26, 1961. Exhibition Brochure. Sally Hazelet Drummond Papers. In the possession of Sally Hazelet Drummond.

Tate Museum. "Non-Objective Art." Tate. Accessed September 24, 2015. http://www.tate.org.uk/learn/online-resources/glossary/n/non-objectiveart.

Twardy, Chuck. "Dynamic Dots Fill Drummond's Career.” The Orlando Sentinel (Orlando, FL), September 8, 1989. Sally Hazelet Drummond Papers. In the possession of Sally Hazelet Drummond.

University of Louisville. "About the University of Louisville.”University of Louisville. Accessed October 5th, 2015. http://louisville.edu/about/.

University of Louisville and Hite Art Institute. "The Hite Art Institute, Department of Fine Arts." Univeristy of Louisville. Accessed October $5^{\text {th }}, 2015$. http://louisville.edu/art/about.

Weber, Hugo, Elayne H. Varian and Finch College Museum of Art. Hugo Weber: A Retrospective Exhibition. New York: Finch College Museum of Art, 1975. Exhibition Catalogue.

Wechsler, Jeffrey, Sam Hunter, Irving Sandler, William Seitz and Matthew Lee Rohn. Abstract Expressionism: Other Dimensions: An Introduction to Small Scale Painterly Abstraction in America, 1940-1965. New Brunswick: Jane Voorhees Zimmerli Art Museum, Rutgers, 1989. Exhibition Catalogue.

Whitney Museum of American Art, John I. H. Baur and Larry Aldrich. Lyrical Abstraction. New York: Whitney Museum of American Art, 1971.

Wood, Paul, Francis Frascina, Jonathan Harris and Charles Harrison. Modernism in Dispute : Art Since the Forties. New Haven: Yale University Press, 1993. 


\section{APPENDIX B}

BIBLIOGRAPHY

Ahlander, Leslie Judd. "Show Raises Question of Lyricism.” Post Times Herald. (Washington, D.C.), March 3, 1963. Sally Hazelet Drummond Papers. In the possession of Sally Hazelet Drummond.

Alexandre Gallery. "Sally Hazelet Drummond: Selected Paintings." Alexandre Gallery, New York, New York. October 27 - November 26, 2005. Press Release, October 2005 and Exhibition Brochure. Artist's File, Sally Hazelet Drummond, Alexandre Gallery.

-“Sally Hazelet Drummond." Alexandregallery.com. http://www.alexandregallery.com/sally-hazelet-drummond.

Allen, Bruce. "Artists Shun Illusions, Paint Purely in the Abstract." The Independent (Hudson, NY), January 18, 1996. Sally Hazelet Drummond Papers. In the possession of Sally Hazelet Drummond.

American Academy and Institute of Arts and Letters. "Hassam and Speicher Fund Purchase Exhibition." American Academy and Institute of Arts and Letters, New York, New York. November 15 - December 19, 1982. Sally Hazelet Drummond Papers. In the possession of Sally Hazelet Drummond.

- "Loan Agreement Between The American Academy of Arts and Letters and Alexandre Gallery." American Academy and Institute of Arts and Letters, New York, New York. April 7, 2007. Sally Hazelet Drummond Papers. In the possession of Sally Hazelet Drummond.

- "Ceremonial." American Academy and Institute of Arts and Letters, New York, New York. May 16, 2007. Sally Hazelet Drummond Papers. In the possession of Sally Hazelet Drummond.

American Association of University Women Bridgeport Branch. "Art Safari." American Association of University Women Bridgeport Branch, Ridgefield, Connecticut. April 5, 1981. Exhibition Brochure. Sally Hazelet Drummond Papers. In the possession of Sally Hazelet Drummond.

“Among Painters in New York Number Sally Hazelet As One." Courier-Journal (Louisville, KY), January 11, 1959. Artists' Files, Sally Hazelet Drummond, Main Branch, Louisville Free Public Library. 
Amos Eno Gallery. "Artists at the Crossroads: A Critical Look at the Past, Present and Future of Artists-Run Spaces.” Amos Eno Gallery, New York, New York. September 17, 1994. Event Brochure. Sally Hazelet Drummond Papers. In the possession of Sally Hazelet Drummond.

Anuszkiewicz, Richard, Lee Bontecou, Chryssa, Sally Hazelet Drummond, Edward Higgins, Robert Indiana, Gabriel Kohn, Michael Lekakis, Richard Lindner, Marisol, Claes Thure Oldenburg, Ad Reinhardt, James Rosenquist, Jason Seley, David Simpson, Dorothy C. Miller and the Museum of Modern Art. Americans 1963. Edited by Dorothy C. Miller. New York: Doubleday \& Company, Inc., 1963.

Art Center. "Jon Cooper Ippolito: Pastels, Watercolors, Oils; Sally Hazelet Drummond: Oil Paintings.” Art Center, Springfield, Ohio. December 3, 1988 - January 11, 1989. Exhibition Mailer. Sally Hazelet Drummond Papers. In the possession of Sally Hazelet Drummond.

- 'Sally Hazelet Drummond: Oil Paintings; Jon Cooper Ippolito: Pastels, Watercolors, Oils.” Art Center, Springfield, Ohio. Decemeber 3, 1988 - January 11, 1989. Exhibition Brochure. Sally Hazelet Drummond Papers. In the possession of Sally Hazelet Drummond.

The Art Center Association of Louisville. "1961 Louisville Art Center Annual.” The Art Center Association of Louisville at The J.B. Speed Art Museum, Louisville, Kentucky. April 1 - April 30, 1961. Exhibition Brochure. John Begley Papers. In the possession of John Begley.

- "Ulfert Wilke" Art Center Association, Louisville, Kentucky. Undated. Biography, Chronology and Curatorial Statement. Artists' Files, Ulfert Wilke, University of Louisville Margaret M. Bridwell Art Library.

Art Center Gallery. "Sally Hazelet." Art Center Gallery, Louisville, Kentucky. November 14 - December 6, 1957. Exhibition Brochure. Artists' Files, Sally Hazelet Drummond, University of Louisville Margaret M. Bridwell Art Library.

Artists Space. "Sally Hazelet Drummond.” Artists Space, New York, New York. February 25 - March 24, 1984. Exhibition Brochure. Artists' Files, Sally Hazelet Drummond, University of Louisville Margaret M. Bridwell Art Library.

- “International Projects." Artists Space, New York, New York. February 25 March 24, 1984. Exhibition Mailer. Sally Hazelet Drummond Papers. In the possession of Sally Hazelet Drummond. 
- “Sally Hazelet Drummond: Paintings, 1971-84.” Artists Space. Press Release, February 1984. Sally Hazelet Drummond Papers. In the possession of Sally Hazelet Drummond.

Ashton, Dore. "Art: Ornamental Forms: Work of Ron Gorchov at Tibor de Nagy Suggests Aspects of All Cultures." Unknown Source. Undated. Sally Hazelet Drummond Papers. In the possession of Sally Hazelet Drummond.

Ausfeld, Margaret Lynne. "Circus Girl Arrested: A History of the Advancing American Art Collection, 1946-1948." In Advancing American Art: Politics and Aesthetics in the State Department Exhibition, 1946-1948. Montgomery: Montgomery Museum of Fine Arts, 1984. Exhibition Catalogue.

Bard, Joellen, Pleiades Gallery, Association of Artist-Run Galleries, Amos Eno Gallery, Dore Ashton, Bruno Palmer-Poroner, Lawrence Alloway. Tenth Street Days: The Co-ops of the 50's: The Galleries: Tanager, Hansa, James, Camino, March, Brata, Phoenix, Area. New York: Education, Art \& Services Inc., 1977. Exhibition Catalogue.

Barnet, Sylvan. A Short Guide to Writing About Art, 11th Edition. Boston: Pearson Education, 2015.

Barrish, Erica and University of Michigan. Reductive Minimalism: Women Artists in Dialogue, 1960-2014. Ann Arbor: University of Michigan Museum of Art, 2014. Exhibition Catalogue.

Berwick, Carly. "Wall Hole, Blossoms Delight in Art Academy's Invitational Show." Bloomberg Muse, March 9, 2007. http://www.bloomberg.com/apps/news?pid=2060188\&sid=a3j9C0oKYeeE\&refer Sally Hazelet Drummond Papers. In the possession of Sally Hazelet Drummond.

Bethel Gallery. "George Chaplin, Sally Hazelet Drummond.” Bethel Gallery, Bethel, Connecticut. July 13 - August 3, 1980. Sally Hazelet Drummond Papers. In the possession of Sally Hazelet Drummond.

Bier, Justus. “ART: Sally Hazelet's Abstract Paintings Are Exhibited." Courier-Journal (Louisville, KY), April 13, 1952. Artists' Files, Sally Hazelet Drummond, University of Louisville Margaret M. Bridwell Art Library.

Bier, Justus and Senta Bier. "Abstract Paintings Attract Three Top Awards In 18th Annual Show Now at Woman's Club." Courier-Journal (Louisville, KY), November 20, 1955. Sally Hazelet Drummond Papers. In the possession of Sally Hazelet Drummond. 
Bier, Senta. "Feininger Photos Shown; Hazelet Work Exhibited." Courier-Journal (Louisville,KY), Undated. Artists' Files, Sally Hazelet Drummond, University of Louisville Margaret M. Bridwell Art Library.

Bladen, Ronald, Lois Dodd, Sally Hazelet Drummond, Al Held, Alex Katz, William King, Philip Pearlstein and George Sugarman. Eight Begin: Artists' Memories of Starting Out, Edited by Ada Katz. Waterville: Colby Museum of Art, 2014.

Blais, Andrée and Chandler G. Screven. Text in the Exhibition Medium. Collection Muséo. Québec: Société des musées québécois, 1995.

Boghosian, Varujan. Varujan Boghosian to Sally Hazelet Drummond. March 7, 2007. Sally Hazelet Drummond Papers. In the possession of Sally Hazelet Drummond.

Boyer, Lynn. "Many Artists to Show Works At Benefit Library Exhibit." The Redding Pilot (Redding, CT), November 14, 1974. Sally Hazelet Drummond Papers. In the possession of Sally Hazelet Drummond.

Brenson, Michael. "“Reopening the 1960's." Unknown Source. ca. 1983. Sally Hazelet Drummond Papers. In the possession of Sally Hazelet Drummond.

- “Art: 12 Artists Shown in 'Underknown." Unknown Source, October 26, 1984. Sally Hazelet Drummond Papers. In the possession of Sally Hazelet Drummond.

Brod, Heather. Heather Brod, Contemporary Collections, Ltd. to Sally Hazelet Drummond. February 22, 2007. Sally Hazelet Drummond Papers. In the possession of Sally Hazelet Drummond.

Burcaw, George Ellis. Introduction to Museum Work. 3rd Edition. American Association for State and Local History Book Series. Walnut Creek: Altamira Press, 1997.

Burnham, Douglas and George Papandreopuolos. "Existentialism.” Internet Encylcopedia: A Peer-Reviewed Academic Resource. Accessed September 24, 2015. http://www.iep.utm.edu/existent/\#SH3a.

Burton, Linette. "Drummonds Play and Paint in New Home on Wilton Road." October 24, 1963. Sally Hazelet Drummond Papers. In the possession of Sally Hazelet Drummond.

- “Dots Intrigue Sally Drummond." Ridgefield Press (Ridgefield, CT), January 18, 1979. Sally Hazelet Drummond Papers. In the possession of Sally Hazelet Drummond. 
Campbell, Lawrence. "Sally Hazelet." Art News Volume 59, Number 1 (March 1960): 40. Art and Architecture Complete, EBSCOhost (accessed October 19, 2015).

- Lawrence Campbell to Sally Hazelet Drummond. February 24, 1972. Sally Hazelet Drummond Papers. In the possession of Sally Hazelet Drummond.

- “Sally Hazelet Drummond Draft 5.” ca. 1972. Sally Hazelet Drummond Papers. In the possession of Sally Hazelet Drummond.

- "Dotted Light." Art News Volume 71, Number 2 (April 1972): 30-73. Art and Architecture Complete, EBSCO Host. Accessed October 16, 2015.

Canaday, John. “Art: 15 Exhibit at Modern.” New York Times (New York, NY), May 22, 1963. Sally Hazelet Drummond Papers. In the possession of Sally Hazelet Drummond.

Chave, Anna. Mark Rothko : Subjects in Abstraction, Edited by George L. Hersey. New Haven: Yale University Press, 1989.

Chilvers, Ian Ed. The Oxford Dictionary of Art. Third Edition. Oxford: Oxford University Press, 2004.

Columbus Museum of Art. Columbus Museum of Art to Philippe Alexandre, Alexandre Gallery. December 6, 2006. Sally Hazelet Drummond Papers. In the possession of Sally Hazelet Drummond.

- "Optic Nerve: Perceptual Art of the 1960s." Columbus Museum of Art, Columbus, Ohio. February 15, 2007. Exhibition Mailer. Sally Hazelet Drummond Papers. In the possession of Sally Hazelet Drummond.

The Corcoran Gallery of Art. "Sally Hazelet Drummond Retrospective." The Corcoran Gallery of Art, Washington, D.C.. November 3 - December 3, 1972. Exhibition Brochure. Sally Hazelet Drummond Papers. In the possession of Sally Hazelet Drummond.

The Cornell Fine Arts Museum. " Sally Hazelet Drummond.” Rollins College, Winter Park, Florida. September 8 - October 15, 1989. Exhibition Mailer and Brochure. Sally Hazelet Drummond Papers. In the possession of Sally Hazelet Drummond.

Crosby, Thomas. “Art with a Punch.” Star-News (Unknown). ca. 1972. Sally Hazelet Drummond Papers. In the possession of Sally Hazelet Drummond.

Dajani, Virginia. Virginia Dajani, American Academy of Arts and Letters to Sally Hazelet Drummond. June 5, 2007. Sally Hazelet Drummond Papers. In the possession of Sally Hazelet Drummond. 
Dana, John Cotton. "The Gloom of the Museum." In Reinventing the Museum: The Evolving Conversation on the Paradigm Shift, Second Edition. Edited by Gail Anderson. Lanham: Alta Mira Press, 2012: 17-33.

Dean, David. Museum Exhibition: Theory and Practice. The Heritage; Heritage. London: Routledge, 1994.

Deepwell, Katy, Ed. New Feminist Art Criticism: Critical Strategies. Manchester: Manchester University Press, 1995.

De Kooning, Elaine. “Subject: What, How or Who?” Art News Volume 54, Number 2 (April1955): 29, 61-62.

De Kooning, Elaine, Rose Slivka and Marjorie Luyckx. The Spirit of Abstract Expressionism : Selected Writings. New York: George Braziller, 1994.

De Kooning, Willem, Thomas B. Hess and Museum of Modern Art. Willem De Kooning. New York: Museum of Modern Art, 1969. Exhibition Catalogue.

Denyer, Ted. Ted Denyer to Sally Hazelet Drummond. April 1994. Sally Hazelet Drummond Papers. In the possession of Sally Hazelet Drummond.

Donohoe, Victoria. “A Fresh Approach to Dot." Philadelphia Inquirer (Philadelphia, PA), November 19, 1978. Sally Hazelet Drummond Papers. In the possession of Sally Hazelet Drummond.

Drummond, Sally Hazelet. artist's statement. Ca. 1952. Sally Hazelet Drummond Papers. In the possession of Sally Hazelet Drummond.

- correspondence, letter to the editor of Art News. ca. 1953. Sally Hazelet Drummond Papers. In the possession of Sally Hazelet Drummond.

- artist's statement. ca. 1965. Sally Hazelet Drummond Papers. In the possession of Sally Hazelet Drummond.

- Sally Hazelet Drummond to Franklin. January 30, 1967. Sally Hazelet Drummond Papers. In the possession of Sally Hazelet Drummond.

- “Festival Features Pointillist Art.” The Western, May 23, 1973. Sally Hazelet Drummond Papers. In the possession of Sally Hazelet Drummond.

- Sally Hazelet Drummond to Cindy Nemser. 1979. Sally Hazelet Drummond Papers. In the possession of Sally Hazelet Drummond. 
- Sally Hazelet Drummond to Sotheby's Auction House. November 2, 1983. Sally Hazelet Drummond Papers. In the possession of Sally Hazelet Drummond.

- Sally Hazelet Drummond to Lee. May 23, 1987. Sally Hazelet Drummond Papers. In the possession of Sally Hazelet Drummond.

- "Supplementary Statement Number One." Ca. 1987. Sally Hazelet Drummond Papers. In the possession of Sally Hazelet Drummond.

- “Supplementary Statement Number II.” Ca. 1987. Sally Hazelet Drummond Papers. In the possession of Sally Hazelet Drummond.

- “Supplementary Statement Number III.” Ca. 1987. Sally Hazelet Drummond Papers. In the possession of Sally Hazelet Drummond.

- Sally Hazelet Drummond to Elisabeth 'Lisa' Hazelet Kah. April 23, 1989. Sally Hazelet Drummond Papers. In the possession of Sally Hazelet Drummond.

- draft for speech for Cornell Art Gallery, Rollins College. Speech delivered September 25, 1989, multiple drafts. Sally Hazelet Drummond Papers. In the possession of Sally Hazelet Drummond.

- Sally Hazelet Drummond to Erik La Prade. October 9, 2009. Sally Hazelet Drummond Papers. In the possession of Sally Hazelet Drummond.

- "Sally Hazelet Drummond." Interview by Erik La Prade. 2009. Transcript. Sally Hazelet Drummond Papers. In the possession of Sally Hazelet Drummond.

- Sally Hazelet Drummond in discussion with the author. July 25, 2015.

Germantown, New York. See Addendum of Hillary Sullivan's Master's Thesis, University of Louisville.

- "Art History." Copy of Speech given at the New School, New York. Undated. Sally Hazelet Drummond Papers. In the possession of Sally Hazelet Drummond.

- artist's statements. Undated, multiple statements. Sally Hazelet Drummond Papers. In the possession of Sally Hazelet Drummond.

- curriculum vitae. Undated, multiple copies. Sally Hazelet Drummond Papers. In the possession of Sally Hazelet Drummond

- “Drummond Mailing List.” Undated. Sally Hazelet Drummond Papers. In the possession of Sally Hazelet Drummond. 
- newspaper clippings. Undated. Sally Hazelet Drummond Papers. In the possession of Sally Hazelet Drummond.

- “Sally Drummond: Painting Indra's Net.” Interview by Sparrow. Undated. Sally Hazelet Drummond Papers. In the possession of Sally Hazelet Drummond.

- "Sally Hazelet Drummond" [curriculum vitae]. Undated. Alexandre Gallery.

"Drummond Work at U of L." Courier-Journal (Louisville, KY), May 1, 1983. Sally Hazelet Drummond Papers. In the possession of Sally Hazelet Drummond.

"Dual Art Exhibits to Open At Delaware Center Friday." Evening Journal (Wilmington, DE), January 7, 1963. Sally Hazelet Drummond Papers. In the possession of Sally Hazelet Drummond.

"Expressing Emotion.” Washington Star (Washington, D.C.), March 1963. Sally Hazelet Drummond Papers. In the possession of Sally Hazelet Drummond.

Five Points Gallery. "Sally Hazelet Drummond, Truman Egleston." Five Points Gallery, East Chatham, New York. April 2 - 23, 1994. Exhibition Brochure. Sally Hazelet Drummond Papers. In the possession of Sally Hazelet Drummond.

Falk, John and Dierking, Lynn. The Museum Experience. Washington: Whalesback Books, 1992.

- The Museum Experience Revisited. Walnut Creek: Left Coast Press, 2013.

Fischbach Gallery. "Sally Hazelet Drummond.” Fischbach Gallery. Press Release, 1968. Sally Hazelet Drummond Papers. In the possession of Sally Hazelet Drummond.

- "Sally Hazelet Drummond." Fischbach Gallery, New York, New York. April 22 May 17, 1972. Exhibition Brochure. Sally Hazelet Drummond Papers. In the possession of Sally Hazelet Drummond.

- "Sally Hazelet Drummond." Fischbach Gallery, New York, New York. November 18 - December 6, 1978. Exhibition Brochure. Sally Hazelet Drummond Papers. In the possession of Sally Hazelet Drummond.

Forgery, Benjamin. "The Art Galleries." The Evening Star and Daily News (Washington, D.C.), November 15, 1972. Sally Hazelet Drummond Papers. In the possession of Sally Hazelet Drummond. 
The Gallery of Contemporary Art. "Abstract Painting: A Sampling of Works from 19591995." The Gallery of Contemporary Art, Hudson, New York. January 11 February 25, 1996. Exhibition Brochure. Sally Hazelet Drummond Papers. In the possession of Sally Hazelet Drummond.

Genauer, Emily. “Still Life with Red Herring.” Harper’s Magazine September 1949.

Gibson, Ann Eden. abstract of proposed session. "Abstract Expressionism's Others." 1990 Annual Meeting-Art History Sessions Announcement and Call for Papers. New York, College Art Association, 1989.

- Issues in Abstract Expressionism: The Artist-Run Periodicals. Ann Arbor: UMI Research Press, 1990.

- Abstract Expressionism : Other Politics. New Haven: Yale University Press, 1997.

Glueck, Grace. “Art in Review; Sally Hazelet Drummond.” The New York Times (New York, NY), November 18, 2005. Accessed September 15, 2015. http://query.nytimes.com/gst/fullpage.html?res=9800E6DF1E3EF93BA25752C1 A9639C8B63\&pagewanted=print.

Goldberg, Arthur A.. Arthur A. Goldberg to Sally Hazelet Drummond. November 16, 1963. Sally Hazelet Drummond Papers. In the possession of Sally Hazelet Drummond.

Goodnough, Robert Ed., “Artists' Sessions at Studio 35 (1950).” In Modern Artists In America, First Series, edited by Robert Motherwell and Ad Reinhardt, 8-23. New York: Wittenborn Schultz, 1950.

Goosen, E.C.. "Rothko: The Omnibus Image." Art News Volume 59, Number 9 (January 1961): 37-39, 60-61.

Green Gallery. Green Gallery to Sally Hazelet Drummond. January 26, 1961. Sally Hazelet Drummond Papers. In the possession of Sally Hazelet Drummond.

- "Sally Hazelet Drummond." Green Gallery, New York, New York. March 13 April 7, 1962. Exhibition Brochure. Sally Hazelet Drummond Papers. In the possession of Sally Hazelet Drummond.

- "Group of Paintings, Sculptures and Drawings." Green Gallery, New York, New York. December 13 - January 7, ca. 1960s. Exhibition Flyer. Sally Hazelet Drummond Papers. In the possession of Sally Hazelet Drummond. 
- Exhibition Flyer. Green Gallery, New York, New York. May 30 - June 25, Ca. 1960s. Exhibition Flyer. Sally Hazelet Drummond Papers. In the possession of Sally Hazelet Drummond.

Greenberg, Clement, Art and Culture. 1961, Reprint Boston: Beacon Press, 1989.

- The Collected Essays and Criticism Volume I: Perceptions and Judgements 19391944. Edited by John O’Brian. Chicago: University of Chicago Press, 1986.

- The Collected Essays and Criticism Volume II: Arrogant Purpose 1945-1949. Edited by John O’Brian. Chicago: University of Chicago Press, 1986.

- The Collected Essays and Criticism Volume III: Affirmations and Refusals 19501956. Edited by John O’Brian. Chicago: University of Chicago Press, 1993.

- The Collected Essays and Criticism Volume IV: Modernism with a Vengeance 1957-1969. Edited by John O’Brian. Chicago: University of Chicago Press, 1993.

- Clement Greenberg: Late Writings. Edited by Robert C. Morgan. Minneapolis: University of Minnesota Press, 2003.

"Group Show of Abstract Paintings Opens at City Gallery." The Register-Star (Hudson, NY), January 8, 1995. Sally Hazelet Drummond Papers. In the possession of Sally Hazelet Drummond.

Gruen, John. The Party is Over Now. New York: The Viking Press Inc, 1972.

Hadley Gallery. “An Exhibition of Paintings by Sally Hazelet.” Hadley Gallery, Louisville, Kentucky. April 5, 1952. Exhibition Brochure.

Harris, Jonathan, Clement Greenberg, Michael Fried, T.J. Clark. Writing Back to Modern Art: After Greenberg, Fried, and Clark. London: Routledge Press, 2005.

Harrison, Helen A. "Arthur G. Dove and the Origins of Abstract Expressionism." American Art Volume 12, Number 1 (Spring 1998): 66-83. Accessed September 25, 2015. http://www.jstor.org/stable/3109291.

"Hazelet Paintings Shown at Art Center." Source Unknown, 1957. Artists' Files, Sally Hazelet Drummond, Main Branch, Louisville Free Public Library.

Hazelet, Sally P. “A Commentary on my Painting," Master's Thesis, University of Louisville, 1952.

- "World of Silent Painting." Arts in Louisville. Number Ten, Volume Two. September, 1957. 
Heilenman, Diane. "The Return of Ulfert Wilke." Courier-Journal (Louisville, KY), April 8, 1984. Artists' Files, Ulfert Wilke, University of Louisville Margaret M. Bridwell Art Library.

- "After Manhattan Show, Exhibit Will Settle in at Owensboro Museum." CourierJournal (Louisville, KY), May 31, 1987. Sally Hazelet Drummond Papers. In the possession of Sally Hazelet Drummond.

- "Sally Drummond Returning." Courier-Journal (Louisville, KY), January 21, 1990. Sally Hazelet Drummond Papers. In the possession of Sally Hazelet Drummond.

Hess, Thomas B. "The Phony Crisis in American Art." Art News. Volume 62, Number 4. Summer 1963: 24-28, 59-60.

Hobbs, Robert Carleton, Gail Levin, Herbert F. Johnson Museum of Art, Cornell University and the Whitney Museum of American Art. Abstract Expressionism: The Formative Years. Ithaca: Cornell University Press, 1978. Exhibition Catalogue.

Housatonic Community College. "American Women Painters." Housatonic Community College, Bridgeport, Connecticut. October 3 - 28, 1976. Sally Hazelet Drummond Papers. In the possession of Sally Hazelet Drummond.

Humblet, Claudine. The New American Abstraction 1950-1970. All Volumes. Milano, Italy: Skira, 2007.

Jachec, Nancy. The Philosophy and Politics of Abstract Expressionism: 1940-1960. Cambridge: Cambridge University Press, 2000.

J.B. Speed Art Museum. Sally Hazelet Drummond and Henry Koehler. J.B. Speed Art Museum. Press Release, April 21, 1967. Artists' Files, Sally Hazelet Drummond, University of Louisville Margaret M. Bridwell Art Library.

- "Sally Hazelet Drummond, Henry Koehler." J.B. Speed Art Museum, Louisville, Kentucky. May 9 - June 4, 1967. Exhibition Brochure. Sally Hazelet Drummond Papers. In the possession of Sally Hazelet Drummond.

- J.B. Speed Art Museum to Sally Hazelet Drummond. June 6, 1967. Sally Hazelet Drummond Papers. In the possession of Sally Hazelet Drummond.

Kah, Elisabeth Hazelet. “The Enlightened Path.” April 28, 1989. Sally Hazelet Drummond Papers. In the possession of Sally Hazelet Drummond. 
Kaprow, Allan. "Editor's Letters." Art News Volume 57, Number 10 (February 1959): 6.

Kay, Joan. "Speed Exhibit Draws Artists Home." Courier-Journal (Louisville, KY), May 9, 1967. Sally Hazelet Drummond Papers. In the possession of Sally Hazelet Drummond.

- "Saturday Wedding Calls Family Home." Courier-Journal (Louisville, KY), June 26, 1968. Sally Hazelet Drummond Papers. In the possession of Sally Hazelet Drummond.

Kenkeleba House, Inc.. Kenkeleba House, Inc. to Sally Hazelet Drummond. April 9, 1985. Sally Hazelet Drummond Papers. In the possession of Sally Hazelet Drummond.

- "The Gathering of the Avant Garde: The Lower East Side, 1948-1970." Kenkeleba House, Inc. New York, New York. April 16, 1985. Press Release. Sally Hazelet Drummond Papers. In the possession of Sally Hazelet Drummond.

Kielb, Francesca. "UMMA Exhibit Pairs Minimalist and Contemporary Art." The Daily (Ann Arbor: MI), November 13, 2014. Artists Files, Sally Hazelet Drummond, Alexandre Gallery.

Klee, Paul and Paul Findlay. On Modern Art. London: Faber and Faber, 1948.

Kramer, Hilton. "Art: Drummond Show at the Corcoran.” The New York Times (New York, NY), November 24, 1972. Sally Hazelet Drummond Papers. Alexandre Gallery.

- “Taste and Talent for the Extravagant." The New York Times (New York, NY). Undated. Sally Hazelet Drummond Papers. In the possession of Sally Hazelet Drummond.

Kreiner, Rich. "Points of Contact." Metroland Magazine (Albany, NY), April 7, 1994. Page 31. Sally Hazelet Drummond Papers. In the possession of Sally Hazelet Drummond.

La Prade, Erik. Erik La Prade to Sally Hazelet Drummond. October 5, 2009. Sally Hazelet Drummond Papers. In the possession of Sally Hazelet Drummond.

- Erik La Prade to Sally Hazelet Drummond. October 9, 2009. Sally Hazelet Drummond Papers. In the possession of Sally Hazelet Drummond.

Landau, Ellen G. Reading Abstract Expressionism: Context and Critique. New Haven: Yale University Press, 2005. 
Lansdell, Sarah. "American Art Then and Now at Speed." Courier-Journal (Louisville, KY), May 7, 1967. Sally Hazelet Drummond Papers. In the possession of Sally Hazelet Drummond.

- "Drummond Paintings at Speed: Doors Ajar on "Another World." CourierJournal (Louisville, KY), May 21, 1967. Sally Hazelet Drummond Papers. In the possession of Sally Hazelet Drummond.

- "Speed Acquires Drummond, Koehler Works." Courier-Journal (Louisville, KY), June 18, 1967. Sally Hazelet Drummond Papers. In the possession of Sally Hazelet Drummond.

- Sarah Lansdell to Sally Hazelet Drummond. July 15, 1967. Sally Hazelet Drummond Papers. In the possession of Sally Hazelet Drummond.

- “Ulfert Wilke at Thor: A Modest Distinction." Courier-Journal \& Times (Louisville, KY), May 17, 1970. Artists' Files, Ulfert Wilke, University of Louisville Margaret M. Bridwell Art Library.

- “A Proud Lot of Kentucky Art to Stay for Keeps." Courier-Journal \& Times (Louisville, KY), December 19, 1971. Sally Hazelet Drummond Papers. In the possession of Sally Hazelet Drummond.

- "Five Openings, One Place." Courier-Journal (Louisville, KY), May 16, 1982. Sally Hazelet Drummond Papers. In the possession of Sally Hazelet Drummond.

- “Art Center Has Vivid Show; Arts Club Works are Incisive." Courier-Journal (Louisville, KY), Undated. Sally Hazelet Drummond Papers. In the possession of Sally Hazelet Drummond.

Leja, Michael. Reframing Abstract Expressionism. New Haven: Yale University Press, 1993.

Lenson, Michael. "The Realm of Art." (Newark, NJ), March 31, 1963. Sally Hazelet Drummond Papers. In the possession of Sally Hazelet Drummond.

Leopold, Helen. "'Silent Paintings' Going to Show." Louisville Times (Louisville, KY), July 23, 1958. Artists' Files, Sally Hazelet, Main Branch, Louisville Free Public Library.

Leonard, Elizabeth. "To Spend Year in France: Guggenheim for Artist." Ridgefield Area News (Ridgefield, CT), April 3, 1967. Sally Hazelet Drummond Papers. In the possession of Sally Hazelet Drummond. 
Louisville Visual Art Association. "Sally Hazelet Drummond.” Louisville Visual Art Association, Louisville, Kentucky. January 22 - March 3, 1990. Exhibition Brochure. Artists' Files, Sally Hazelet Drummond, University of Louisville Margaret M. Bridwell Art Library.

Lutz, Nancy. "Drummond, And Chaplin In Bethel.” July 1980. Sally Hazelet Drummond Papers. In the possession of Sally Hazelet Drummond.

Malraux, Andre. The Psychology of Art. The Bollingen Series, XXIV. New York: Pantheon Books, 1949.

Margarete Roeder Gallery. "Surface \& Proportion.” Margarete Roeder Gallery, New York, New York. March 3 - 31, 1990. Exhibition Brochure. Sally Hazelet Drummond Papers. In the possession of Sally Hazelet Drummond.

Martin Agnes, Richard Tuttle, Modern Art Museum of Fort Worth and Site Santa Fe. Agnes Martin, Richard Tuttle. Fort Worth: Modern Art Museum of Fort Worth, 1998. Exhibition Catalogue.

Martin, Agnes, Rhea Anastas, Lynne Cooke, Douglas Crimp, Suzanne Hudson, Jonathan D. Katz, Zoe Leonard, Jaleh Mansoor, Michael Newman, Christina Bryan Rosenberger and Anne M. Wagner. Agnes Martin. Edited by Lynne Cooke, Karen Kelly and Barbara Schroder. New Haven: Yale University Press and Dia Art Foundation, 2001.

Martin, Agnes and Dieter Schwartz. Agnes Martin: Writings. Ostfildern-Ruit: Hatje Cantz, 2005. Exhibition Catalogue.

Martin, Agnes and Arne Glimcher. Agnes Martin: Paintings, Writings, Remembrances. London: Phaidon Press, 2012.

Martin, Agnes, Marion Ackerman, Rachel Barker, Jacquelynn Baas, Christina Bryan Rosenberger, Briony Fer, Lena Fritsch, Anna Lovatt, Maria Muller-Schareck, Richard Tobin and Rosemarie Trockel. Agnes Martin. Edited by Frances Morris and Tiffany Bell. London: Tate Publishing, 2015. Exhibition Catalogue.

McClellan, Andre Ed.. Art and Its Publics: Museum Studies at the Millennium. Malden: Blackwell Publishing, 2003.

Merkling, Frank. "Sally Hazelet Drummond: the 'beautiful light." New-Times (Danbury, CT), June 12, 1980. Sally Hazelet Drummond Papers. In the possession of Sally Hazelet Drummond.

- "Ridgefield Artists in the Limelight." News-Times (Danbury, CT), Ca. 1984. Sally Hazelet Drummond Papers. In the possession of Sally Hazelet Drummond. 
Metropolitan Museum of Art and American Association of Museums. Standards Manual for Signs and Labels: 1995. Professional Practice Series. 1995. Reprint, Washington: Technical Information Service, 2005.

Micchelli, Thomas. “The Anti-Expressionist: Jack Tworkov's Paradigm Shift.” Hyperallergic, September 5, 2015. http://hyperallergic.com/234367/the-antiexpressionist-jack-tworkovs-paradigm-shift/.

"Minimalist Voices of the Past and Present." The Huffington Post, October 13, 2014. http:www.huffingtonpost.com/mutualart/minimalist-voices-of-theb_5969464.html. Artists Files, Sally Hazelet Drummond, Alexandre Gallery.

Mitchell Algus Gallery. "Sally Hazelet Drummond: Paintings 1960-2000." Mitchell Algus Gallery, New York, New York. October 18 - November 15, 2003. Exhibition Brochure. Artists' File, Sally Hazelet Drummond, Alexandre Gallery.

- “Sally Hazelet Drummond: Paintings 1960-2000.” Mitchell Algus Gallery, New York, New York. October 18 - November 15, 2003. Exhibition Price List and Press Release. Sally Hazelet Drummond Papers. In the possession of Sally Hazelet Drummond.

“Modern Art Show." Long Island Press (Jamaica, NY), March 10, 1963. Sally Hazelet Drummond Papers. In the possession of Sally Hazelet Drummond.

Motherwell, Robert., Dore. Ashton, Jack D. Flam, Robert T. Buck, and Albright-Knox Art Gallery. Robert Motherwell. New York: Abbeville Press, 1983. Exhibition Catalogue.

Motherwell, Robert. The Collected Writings of Robert Motherwell, Edited by Stephanie Terenzio. New York: Oxford University Press, 1992.

“Mrs. Drummond Gets Grant.” Unknown Source. April 9, 1967. Artists' Files, Sally Hazelet Drummond, Main Branch, Louisville Free Public Library.

Mullican, Lee. Lee Mullican to Sally Hazelet Drummond. July 14, 1986. Sally Hazelet Drummond Papers. In the possession of Sally Hazelet Drummond.

Museum of Modern Art. The New American Paintings As Shown in Eight European Countries, 1958-1959. New York: Museum of Modern Art, 1959.

- “Recent Acquisitions.” Museum of Modern Art, New York, New York. November 20, 1962 - January 13, 1963. Exhibition Checklist. Sally Hazelet Drummond Papers. In the possession of Sally Hazelet Drummond. 
- “Americans 1963.” Museum of Modern Art, New York, New York. 1963. Exhibition Brochure. Sally Hazelet Drummond Papers. In the possession of Sally Hazelet Drummond.

- “Cubism," Museum of Modern Art Learning, Accessed September 24, 2015, https://www.moma.org/learn/moma_learning/themes/cubism.

- “German Expressionism,” Museum of Modern Art, Accessed September 24, 2015, http://www.moma.org/explore/collection/ge/styles/index.

- "Surrealism." Museum of Modern Art Learning. Accessed September 24, 2015. https://www.moma.org/learn/moma_learning/themes/surrealism.

Nemser, Cindy. Cindy Nemser to Sally Hazelet Drummond. January 6, 1979. Sally Hazelet Drummond Papers. In the possession of Sally Hazelet Drummond.

O’Doherty, Brian. “Art: 3 Painting Displays.” New York Times (New York: NY), March, 1962. Sally Hazelet Drummond Papers. In the possession of Sally Hazelet Drummond.

Owensboro Museum of Fine Art. Owensboro Museum of Fine Art to Sally Hazelet Drummond. November 7, 1986. Sally Hazelet Drummond Papers. In the possession of Sally Hazelet Drummond.

- “Loan Agreement." February 17, 1987. Sally Hazelet Drummond Papers. In the possession of Sally Hazelet Drummond.

Parman, Alice and Jeffrey Jane Flowers. Exhibit Makeovers: A Do-It-Yourself Workbook for Small Museums. Lanham: Alta Mira Press, 2008.

Pearson, Deborah. “Art Show Offers Variety of Views.” Waterbury Republican (Waterbury, CT), June 27, 1974. Sally Hazelet Drummond Papers. In the possession of Sally Hazelet Drummond.

Philadelphia College of Art. "Point." Philadelphia College of Art, Philadelphia, Pennsylvania. November 18 - December 15, 1978. Exhibition Brochure. Sally Hazelet Drummond Papers. In the possession of Sally Hazelet Drummond.

Poirier, Maurice and Jane Necol. "The "60s in Abstract: 13 Statements and an Essay." Art in America, October 1983: 122-137.

Polcari, Stephen. Abstract Expressionism and the Modern Experience. Cambridge England: Cambridge University Press, 1991. 
Primus Stuart Galleries. "Ulfert Wilke.” Primus Stuart Galleries, Los Angeles, California. November 1961. Exhibition Flyer. Artists' Files, Ulfert Wilke, University of Louisville Margaret M. Bridwell Art Library.

Provosty, Nathlie. "Eight Begin: Artists' Memories of Starting Out." The Brooklyn Rail. Accessed July 15, 2015. http://www.brooklynrail.org/2014/12/art books/eightbegin-artist-memories-of-starting-out.

P.S. 1 Museum. “Abstract Painting: 1960-1969.” P.S. 1 Museum, Long Island City, New York. January 16 - March 13, 1983. Exhibition Brochure. Sally Hazelet Drummond Papers. In the possession of Sally Hazelet Drummond.

- “P.S. 1 Reopens the 60's." P.S. 1 Museum, Long Island City, New York. January 16, 1983. Exhibition Mailer. Sally Hazelet Drummond Papers. In the possession of Sally Hazelet Drummond.

P.S. 1 Museum, Carl Andre, Dore Ashton, Gene Baro, Bill Berkson, David Bourdon, Lawrence Campbell, Paul Cummings, E.C. Goosen, Will Insley, Barabar Jakobson, Ellen Johnson, Janet Kardon, Klaus Kertess, Hilton Kramer, Kim Levin, Lucy R. Lippard, Jane Livingston, Linda Nochlin, John Perreault, Carter Ratcliff, Robert Rosenblum, Agnes Saalfield, Irving Sandler, Peter Schjeldahl, Holly Solomon, Dorothy Vogel, Donald Droll and Jane Necol. Abstract Painting: 1960-1969: Jo Baer, James Bishop, Sally Hazelet Drummond, Marcia Hafif, Al Held, Ralph Humphrey, Will Insley, Lee Lozano, Robert Mangold, Brice Marden, Agnes Martin, David Novros, Doug Ohlson, Robert Ryman, Tony Smith. Long Island City: Institute for Art and Urban Resources, 1983.

Puniello, Francoise S. and Halina R. Rusak. Abstract Expressionist Women Painters: An Annotated Bibliography: Elaine de Kooning, Helen Frankenthaler, Grace Hartigan, Lee Krasner, Joan Mitchell, Ethel Schwabacher. Lanham: The Scarecrow Press, 1996.

"Quattrodici Artisti Americani." Ca. 1953. Exhibition Brochure. Sally Hazelet Drummond Papers. In the possession of Sally Hazelet Drummond.

Ramey, Lorrie Kyle. “An Illustrated Life.” In Rollins Alumni Record. Winter 1990, 2728. Sally Hazelet Drummond Papers. In the possession of Sally Hazelet Drummond.

Ravelli, Louise. Museum Texts: Communication Framework. Abingdon: Routledge, 2006.

Raynor, Vivien. "Tranquil, Sad and Quite Beautiful." New York Times (New York, NY), November, 1978. Sally Hazelet Drummond Papers. In the possession of Sally Hazelet Drummond. 
Richard, Paul. “Corcoran Combatants Seek Peace.” The Washington Post (Washington, D.C.), November 5, 1972. Sally Hazelet Drummond Papers. In the possession of Sally Hazelet Drummond.

- "Raising the Corcoran Question." Unknown Source. Undated. Sally Hazelet Drummond Papers. In the possession of Sally Hazelet Drummond.

Roberts, Lisa C.. From Knowledge to Narrative: Educators and the Changing Museum. Washington D.C.: Smithsonian Institution Press, 1997.

Robinson, Hilary, Ed. Feminism-Art-Theory: An Anthology 1968-2000. Oxford: Blackwell Publishers, 2001.

Rosenberg, Harold. The Tradition of the New. New York: Horizon Press, 1959.

- Discovering the Present : Three Decades in Art, Culture, and Politics. Chicago: University of Chicago Press, 1973.

Russell, John. "The Flavor of 1950's New York.” The New York Times (New York, NY), February 18, 1979. Sally Hazelet Drummond Papers. In the possession of Sally Hazelet Drummond.

"Sally Hazelet Drummond.” The New York Times (New York, NY), March 9, 1984. Sally Hazelet Drummond Papers. In the possession of Sally Hazelet Drummond.

"Sally Drummond in Housatonic Show." Ridgefield Press (Ridgefield, CT), October 14, 1976. Sally Hazelet Drummond Papers. In the possession of Sally Hazelet Drummond.

Sandler, Irving. "Sally Hazelet Drummond's." New York Post (New York, NY), April, 1962. Sally Hazelet Drummond Papers. In the possession of Sally Hazelet Drummond.

- The Triumph of American Painting: A History of Abstract Expressionism. New York: Praeger, 1970.

- $\quad$ The New York School. New York: Harper and Row Publishers, 1978.

- American Art of the 1960s. New York: Harper and Row Publishers, 1988.

- Art of the Postmodern Era : From the Late 1960s to the Early 1990s. New York: Icon Editions, 1996. 
- From Avant-Garde to Pluralism : An On-The-Spot History. Lenox, MA: Hard Press Editions, 2006.

- Abstract Expressionism and the American Experience: A Reevaluation. New York: Hard Press Editions Inc, 2009.

Scott, Martha B. "Not a Feminist Show but a Triumph for Women's Art." Bridgeport Sunday Post (Bridgeport, CT), October 24, 1976. Sally Hazelet Drummond Papers. In the possession of Sally Hazelet Drummond.

- "Sun Spots and Sun-Streaked Horizons Glow from Walls." Bridgeport Sunday Post (Bridgeport, CT), July 20, 1980. Sally Hazelet Drummond Papers. In the possession of Sally Hazelet Drummond.

- "Aldrich Museum of Contemporary Art/ Ridgefield; Sally Hazelet Drummond." Art New England Volume II, Number 4. March 1981. Sally Hazelet Drummond Papers. In the possession of Sally Hazelet Drummond.

Scott, Sue, Gerald Nordland and Orlando Museum of Art. Washington Color Painters: The First Generation: Gene Davis, Thomas Downing, Morris Louis, Howard Mehring, Kenneth Noland. Orlando: Orlando Museum of Art, 1990. Exhibition Catalogue.

Secrest, Meryle. "Artists Ahead of the Times." Post-Times Herald (Washington, D.C.), March 4, 1963. Sally Hazelet Drummond Papers. In the possession of Sally Hazelet Drummond.

Serrell, Beverly. Exhibit Labels: An Interpretive Approach. Walnut Creek: Alta Mira Press, 1996.

- Judging Exhibitions: A Framework for Assessing Excellence. Walnut Creek: Left Coast Press, 2006.

“Selected for Show." Courier-Journal (Louisville, KY), 1959. Artists' Files, Sally Hazelet Drummond, Main Branch, Louisville Free Public Library.

Seuphor, Michel, Lionel Izod, John Montague and Francis Scarfe. Dictionary of Abstract Painting with a History of Abstract Painting. New York: Tudor Publishing Company, 1957.

Shaw, Harry. “The Painting is 'Silent,' but Viewers Aren't.” Courier-Journal (Louisville, KY), November 17, 1957. Sally Hazelet Drummond Papers. In the possession of Sally Hazelet Drummond. 
Slavin, Maeve. "Seven Women Artists." Preview June, 1974. Sally Hazelet Drummond Papers. In the possession of Sally Hazelet Drummond.

Smith, Katherine T. “Artists Bring Full Portfolios from Italy and France.” The Louisville Times (Louisville, KY), ca. 1953. Sally Hazelet Drummond Papers. In the possession of Sally Hazelet Drummond.

- “Louisvillian's Art Exhibited." The Louisville Times (Louisville, KY), May 31, 1963. Sally Hazelet Drummond Papers. In the possession of Sally Hazelet Drummond.

Smith, Roberta. "Richard Bellamy, Art Dealer, Is Dead at 70." The New York Times (New York, NY), April 3, 1998. http://www.nytimes.com/1998/04/03/arts/richard-bellamy-art-dealer-is-dead-at70.html.

Smithsonian Institution and the Institute of International Education. "Fulbright Painters." Washington: The Institute of International Education, 1958. Sally Hazelet Drummond Papers. In the possession of Sally Hazelet Drummond.

Snyder, Bettie. "Sally Drummond Showing Work at Sharon Church.” Ridgefield Press (Ridgefield, CT), May 24, 1973. Sally Hazelet Drummond Papers. In the possession of Sally Hazelet Drummond.

Steinhauer, Jillian. "Finally, an Exhibition Devoted to the Women of Abstract Expressionism." Hyperallergic, September 24, 2015. http://hyperallergic.com/239282/finally-an-exhibition-devoted-to-thewomen-of-abstract-expressionism/.

Stryker, Mark. "U-M Museum Showcases 2 Generations of Women Minimalists." Detroit Free Press. January 4, 2015. Accessed July 15, 2015. http://www.freep.com/story/entertainment/arts/2015/01/04/minimalism-martinmichigan-museum/21193859/.

"'Swinging' Exhibit: Jazz Music Backgrounds Abstract Paintings in Muskegon's Hackley Gallery." Grand Rapids Press (Grand Rapids, MI), November 11, 1962. Sally Hazelet Drummond Papers. In the possession of Sally Hazelet Drummond.

Tanager Gallery. "Sally Hazelet." Tanager Gallery, New York, New York. April 1 - 21, 1960. Exhibition Brochure. Artists' Files, Sally Hazelet Drummond, University of Louisville Margaret M. Bridwell Art Library.

- "The Private Myth." Tanager Gallery, New York, New York. October 6 - 26, 1961. Exhibition Brochure. Sally Hazelet Drummond Papers. In the possession of Sally Hazelet Drummond. 
- “1952-1956.” Tanager Gallery, New York, New York. January 27-February 16, 1956. Exhibition Brochure.

Tate Museum. "Non-Objective Art." Tate. Accessed September 24, 2015. http://www.tate.org.uk/learn/online-resources/glossary/n/non-objective-art.

Taylor, Francis Henry. "Modern Art and the Dignity of Man." Atlantic Monthly, December 1948.

Tellitall, Dot. "Peace Also is Expected to Relieve Shortage of Men." Courier-Journal (Louisville, KY). ca. 1944. Sally Hazelet Drummond Papers. In the possession of Sally Hazelet Drummond.

Twardy, Chuck. "Dynamic Dots Fill Drummond's Career." The Orlando Sentinel (Orlando, FL), September 8, 1989. Sally Hazelet Drummond Papers. In the possession of Sally Hazelet Drummond.

Ulmer, D.C. Jr. D.C. Ulmer Jr. to Sally Hazelet Drummond. December 31, 1971. Sally Hazelet Drummond Papers. In the possession of Sally Hazelet Drummond.

University of Louisville. "About the University of Louisville."University of Louisville. Accessed October 5th, 2015. http://louisville.edu/about/.

University of Louisville and Hite Art Institute. "The Hite Art Institute, Department of Fine Arts." Univeristy of Louisville. Accessed October 5th, 2015.http://louisville.edu/art/about.

University of Michigan Museum of Art. "Reductive Minimalism: Women Artists in Dialogue,1960-2014." University of Michigan, Ann Arbor, Michigan. October 4, 2014 - January 25, 2015. Press Release. Artists Files, Sally Hazelet Drummond, Alexandre Gallery.

Upstate Art. “Group Show \#1.” Upstate Art, Phoenicia, New York. June 26 - June 27, 1999. Exhibition Brochure. Sally Hazelet Drummond Papers. In the possession of Sally Hazelet Drummond.

- "Notions of Beauty." Upstate Art, Phoenicia, New York. August 19 - September 17, 2000.Exhibition Brochure. Sally Hazelet Drummond Papers. In the possession of Sally Hazelet Drummond. 
Washington Art Association. "Three Northeast Artists Display Work at Washington Art Association." Washington Art Association, Washington Depot, Connecticut. September 29- October 21, 1990. Press Release, Exhibition Brochure and Exhibition Layout. Sally Hazelet Drummond Papers. In the possession of Sally Hazelet Drummond.

Wayne, Kenneth, Karen Wilkin, Patrick and Beatrice Haggerty Museum of Art, AlbrightKnox Art Gallery. Color Field Revisited: Paintings from the Albright-Knox Art Gallery. Milwaukee: Haggerty Museum of Art, Marquette University, 2004. Exhibition Catalogue.

Weber, Hugo, Elayne H. Varian and Finch College Museum of Art. Hugo Weber: A Retrospective Exhibition. New York: Finch College Museum of Art, 1975. Exhibition Catalogue.

Wechsler, Jeffrey, Sam Hunter, Irving Sandler, William Seitz and Matthew Lee Rohn. Abstract Expressionism: Other Dimensions: An Introduction to Small Scale Painterly Abstraction in America, 1940-1965. New Brunswick: Jane Voorhees Zimmerli Art Museum, Rutgers, 1989. Exhibition Catalogue.

Weismann, Donald L. Ulfert Wilke: Retrospective Exhibition. Louisville: The Franklin Printing Company, 1953. Artists' Files, Ulfert Wilke, University of Louisville Margaret M. Bridwell Art Library.

The Westmoreland County Museum of Art. "Recent Trends in American Art." The Westmoreland County Museum of Art, Greensburg, Pennsylvania. May 25 - July 6, 1969. Exhibition Brochure. Sally Hazelet Drummond Papers. In the possession of Sally Hazelet Drummond.

Whitney Museum of American Art. loan paperwork. November 23, 1959. Sally Hazelet Drummond Papers. In the possession of Sally Hazelet Drummond.

- “1959 Annual Exhibition of Contemporary American Painting." Whitney Museum of American Art. December 9, 1959 - January 31, 1960. Exhibition Brochure

- Whitney Museum of American Art to Sally Hazelet Drummond. February 24, 1965. Sally Hazelet Drummond Papers. In the possession of Sally Hazelet Drummond.

Whitney Museum of American Art, John I. H. Baur and Larry Aldrich. Lyrical Abstraction. New York: Whitney Museum of American Art, 1971. 
Wood, Paul, Francis Frascina, Jonathan Harris and Charles Harrison. Modernism in Dispute : Art Since the Forties. New Haven: Yale University Press, 1993. 
APPENDIX C

IMAGES OF DRUMMOND'S ART

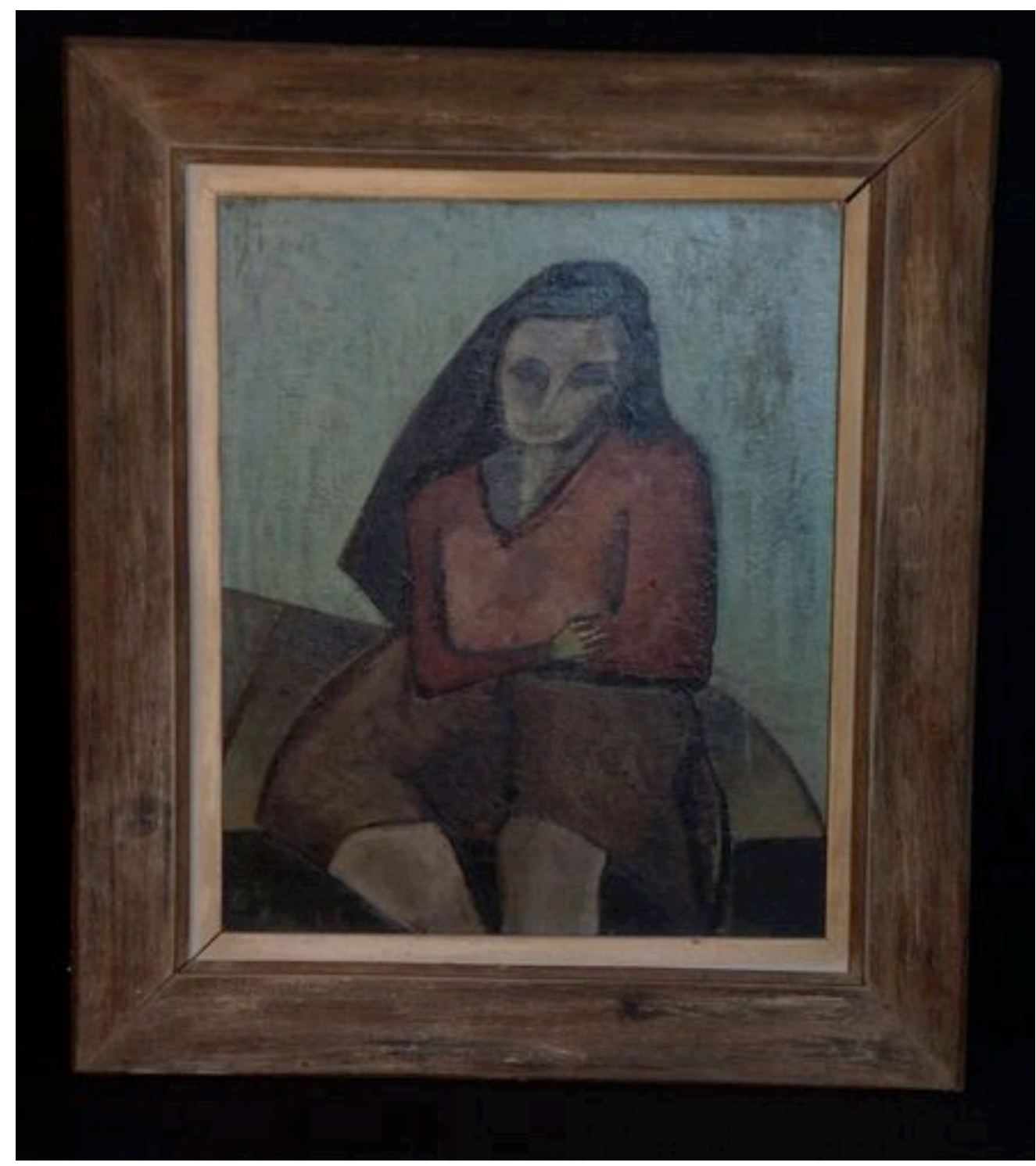

Figure 1.

Girl Sitting, c. 1940, Oil on Masonite, 20"x24", Collection of Mr. and Mrs. John H. Clark IV 


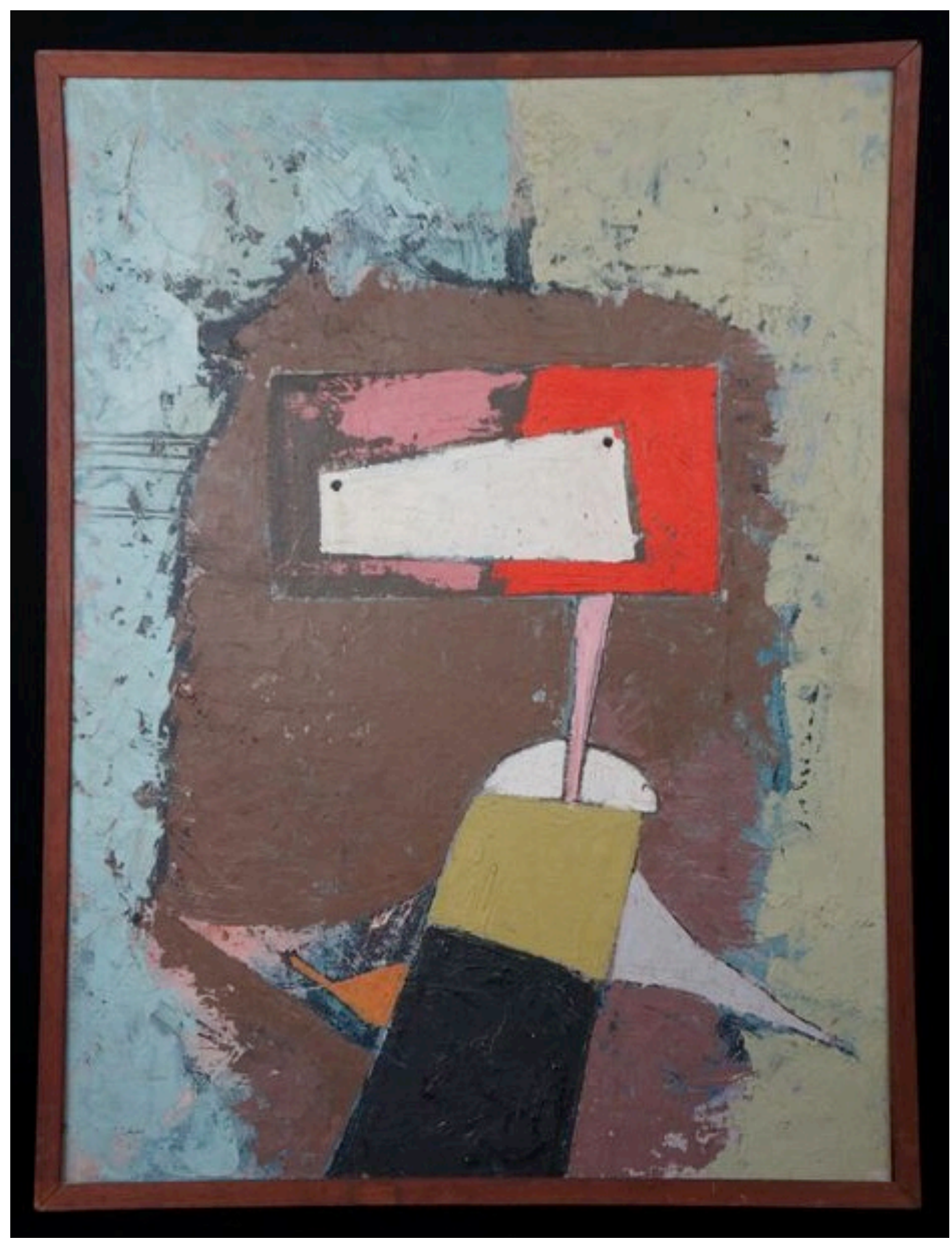

Figure 2.

Girl in a Doorway, 1949, Oil on Canvas, 18" x 24", Collection of the Artist 


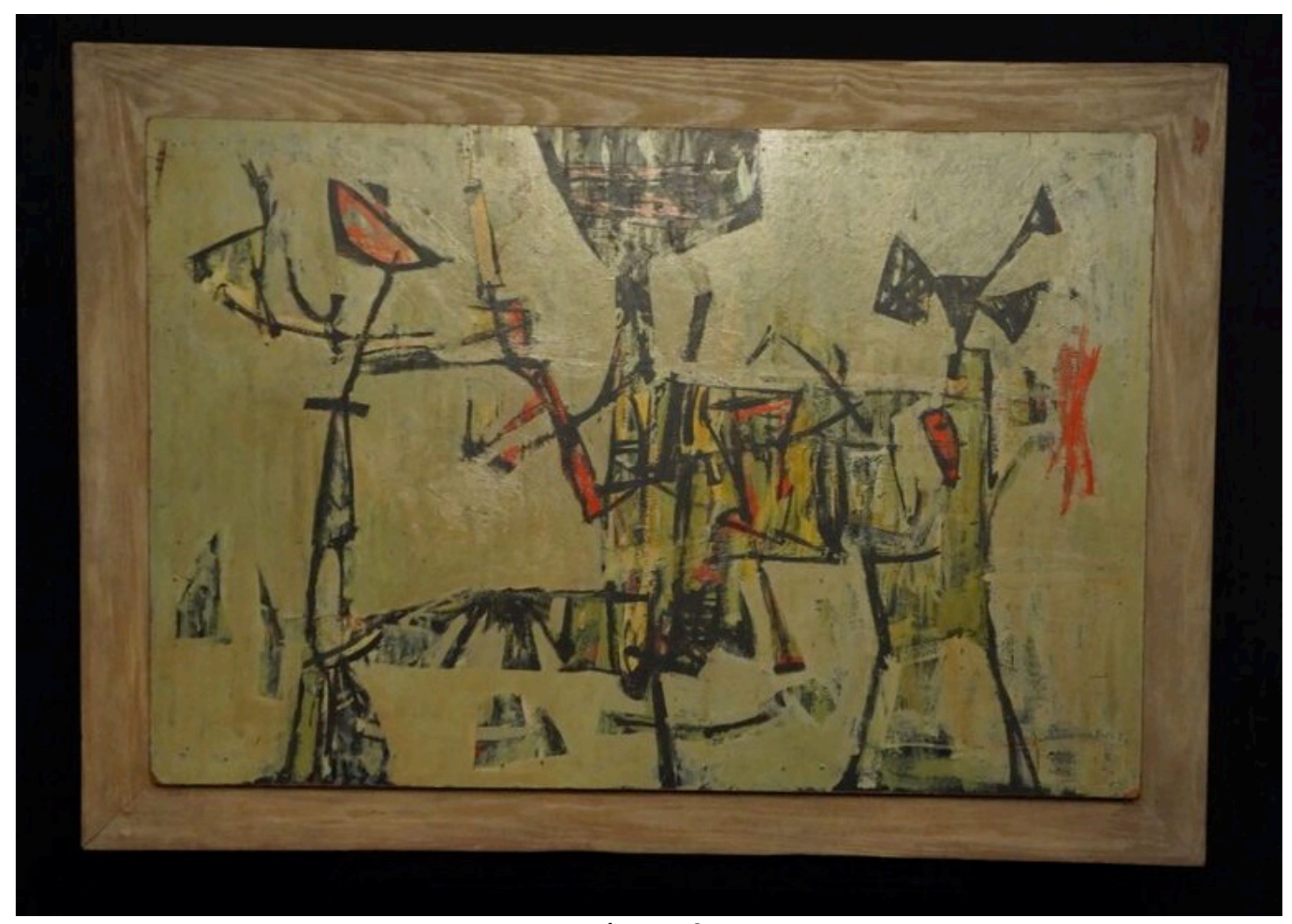

Figure 3.

Magician, 1951, Lacquer on Gessoed Masonite, 48" x 32", Collection of the Artist 


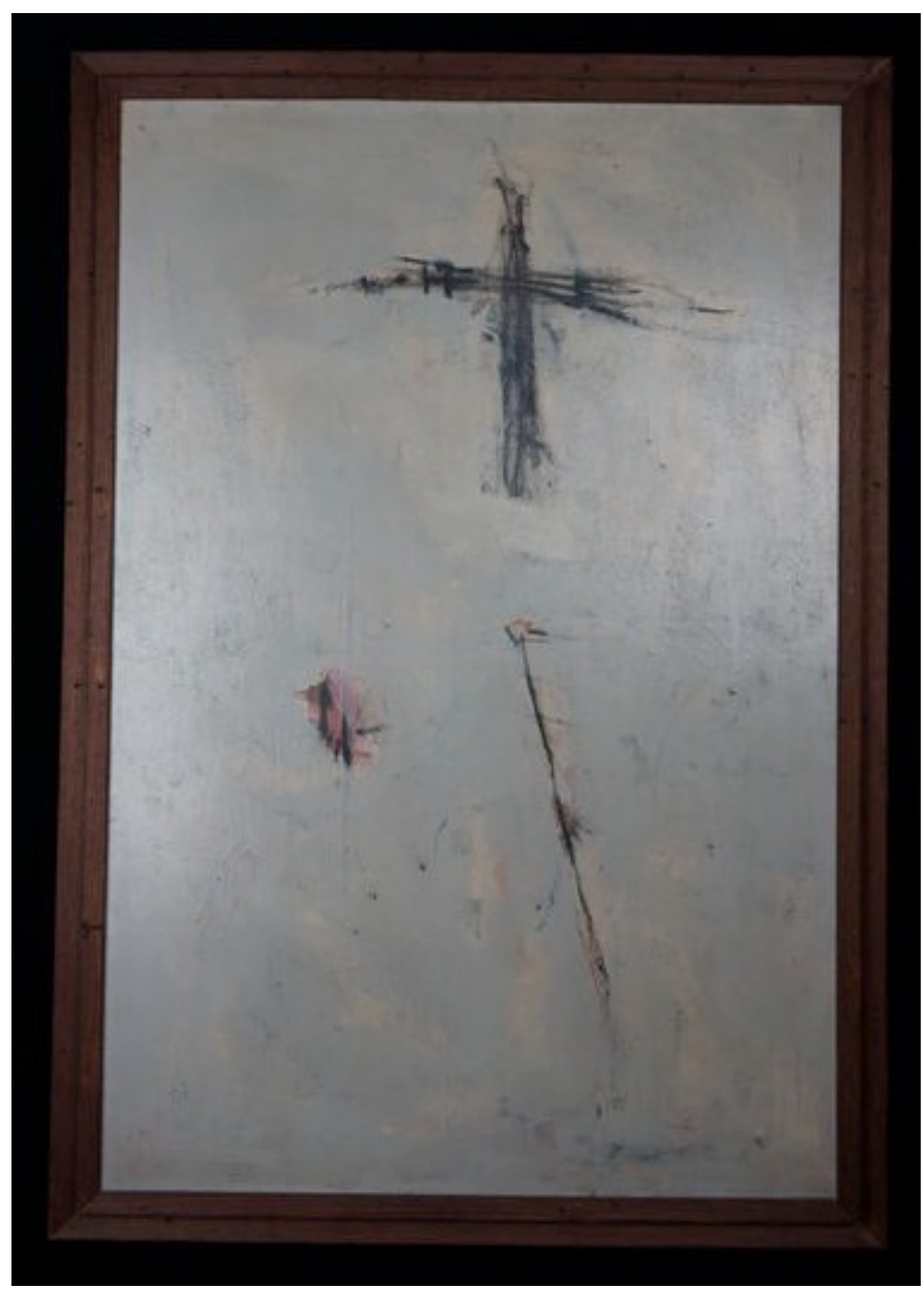

Figure 4.

Untitled, c. 1952, Lacquer on Gessoed Masonite, 24" x 36", Collection of the Artist 


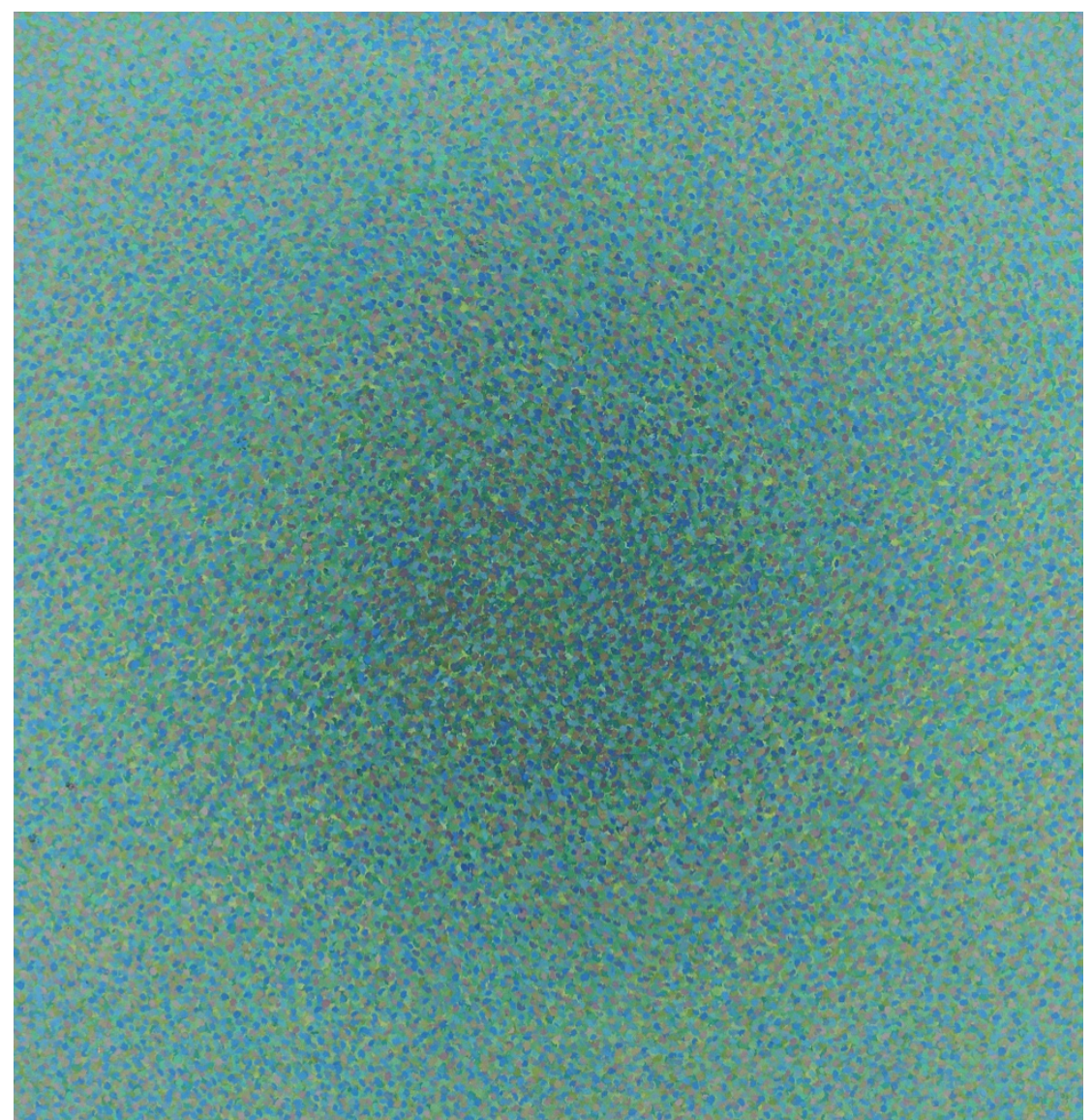

Figure 5.

Bluebird, 1960, Oil on Canvas, 24" x 24", Alexandre Gallery (C) Sally Hazelet Drummond, courtesy Alexandre Gallery, New York 
Figure 6.

Heart of Iron, c. 1960, Oil on Canvas, 60" x 60", Alexandre Gallery (C) Sally Hazelet Drummond, courtesy Alexandre Gallery, New York 


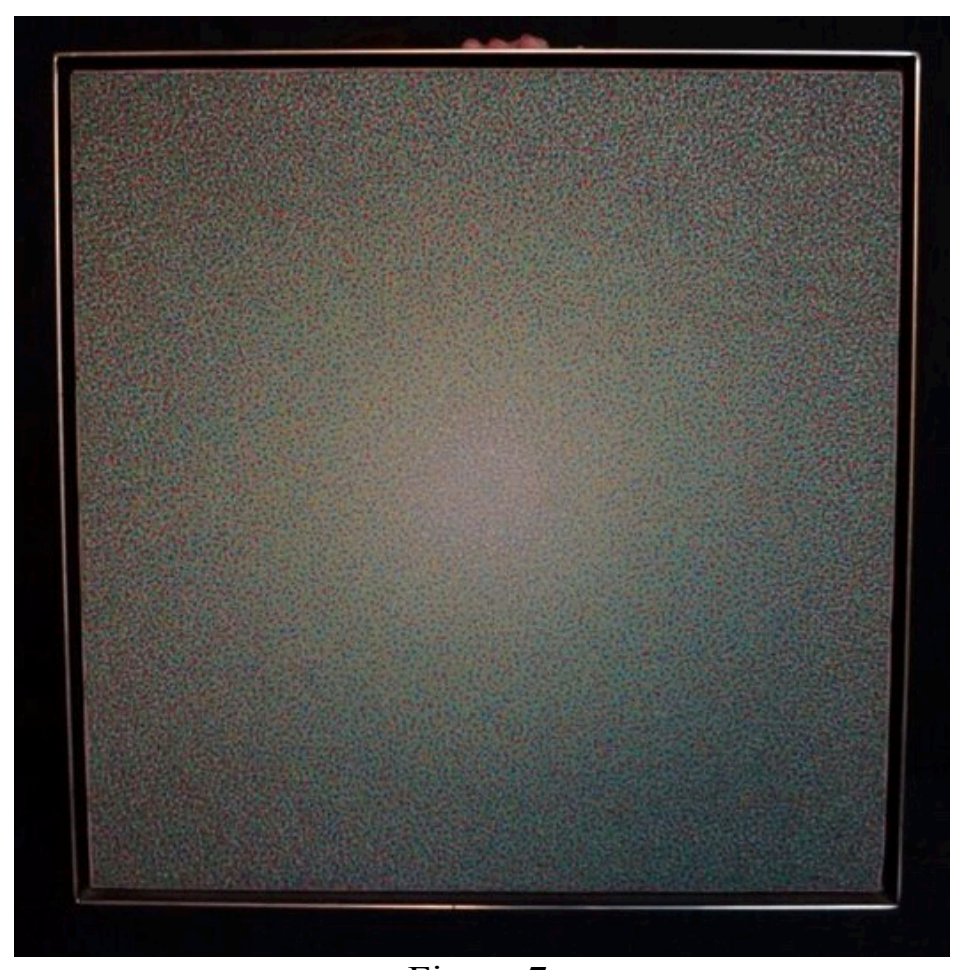

Figure 7.

A Simple Arrangement, 1969, Oil on Canvas, 18" x 18”, Collection of Mr. and Mrs. John H. Clark IV 


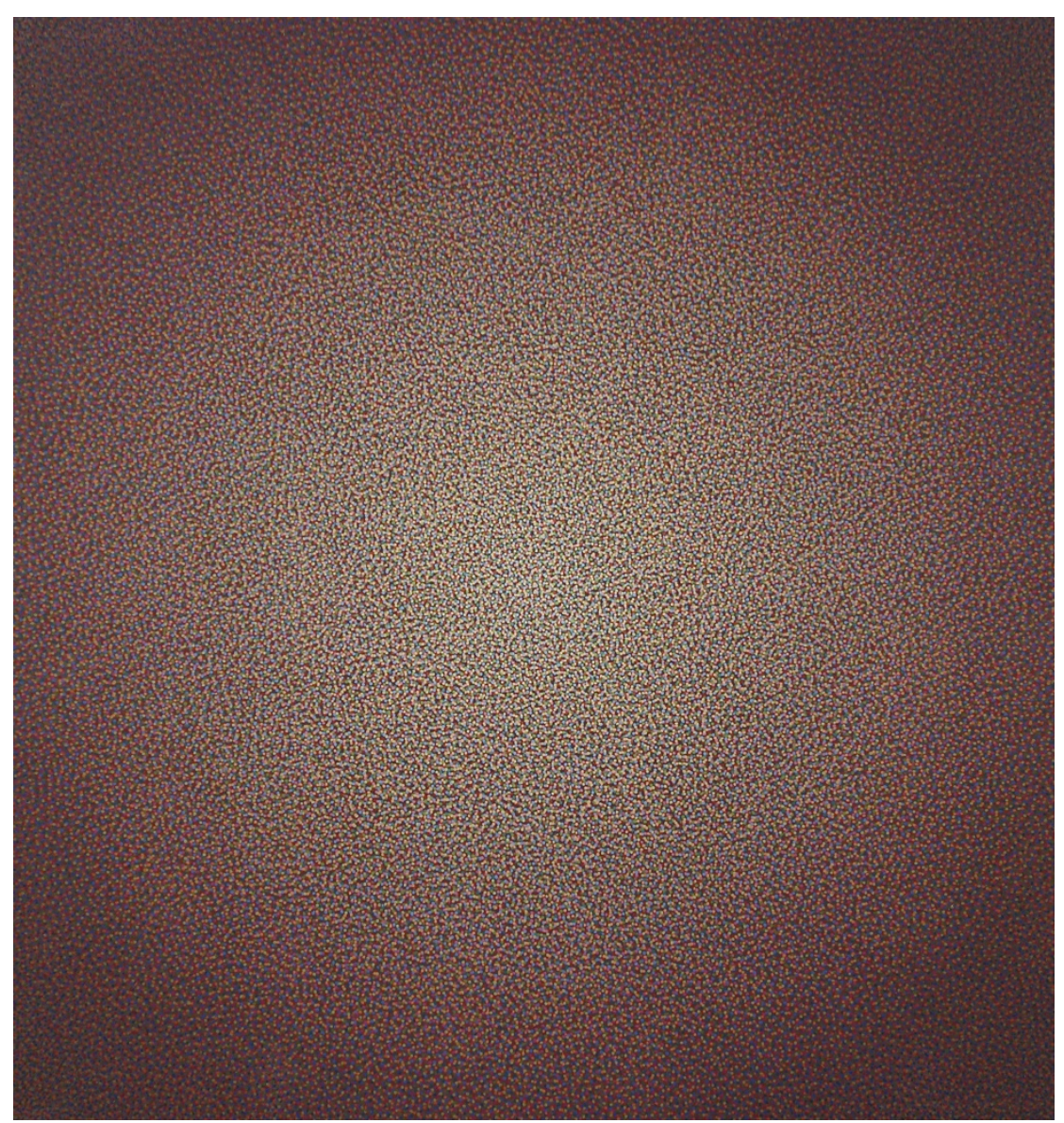

Figure 8.

Union Place, 1978, Oil on Canvas, 40" x 40", Alexandre Gallery CSally Hazelet Drummond, courtesy Alexandre Gallery, New York 


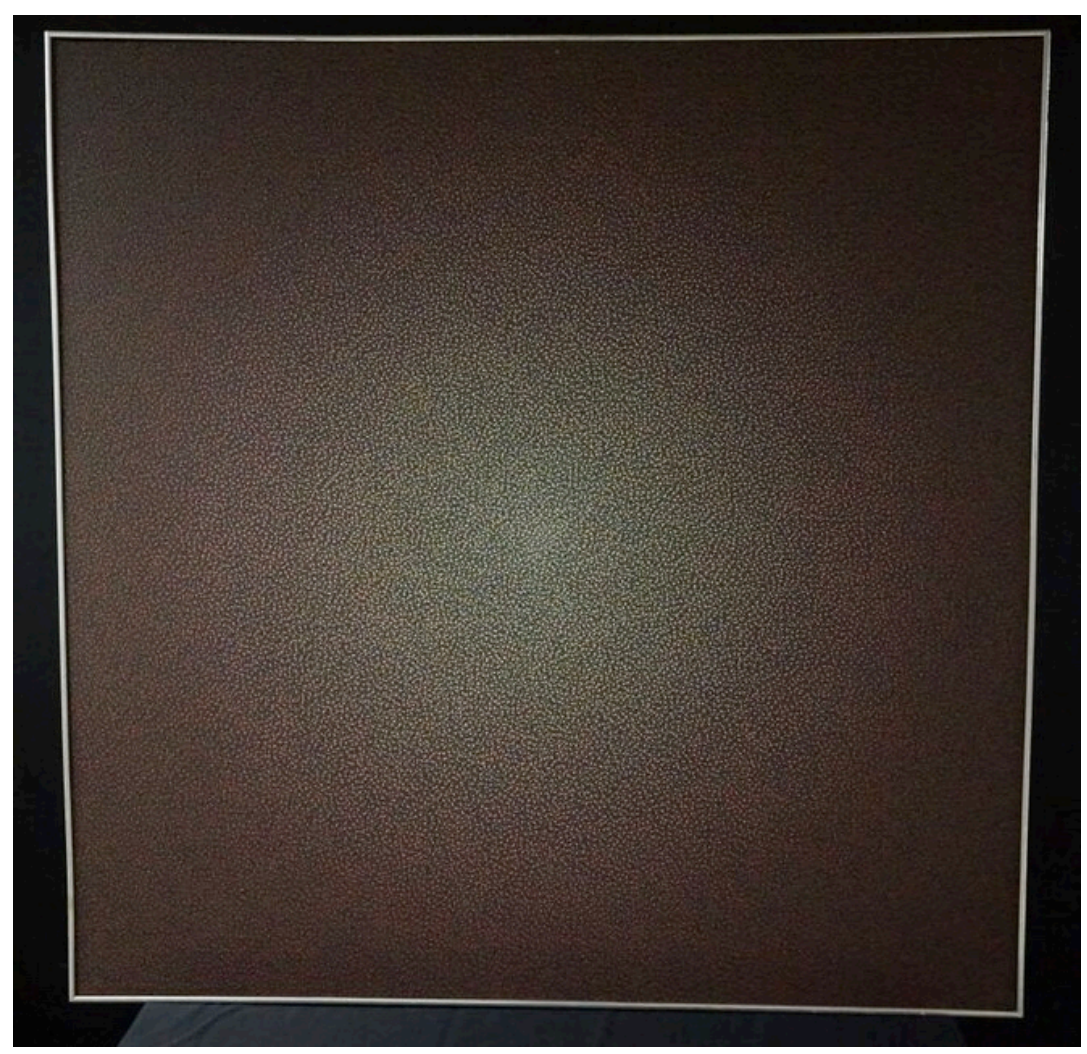

Figure 9.

Night Flight, 1978, Oil on Canvas, 50" x 50", University of Louisville Hite Art Institute 


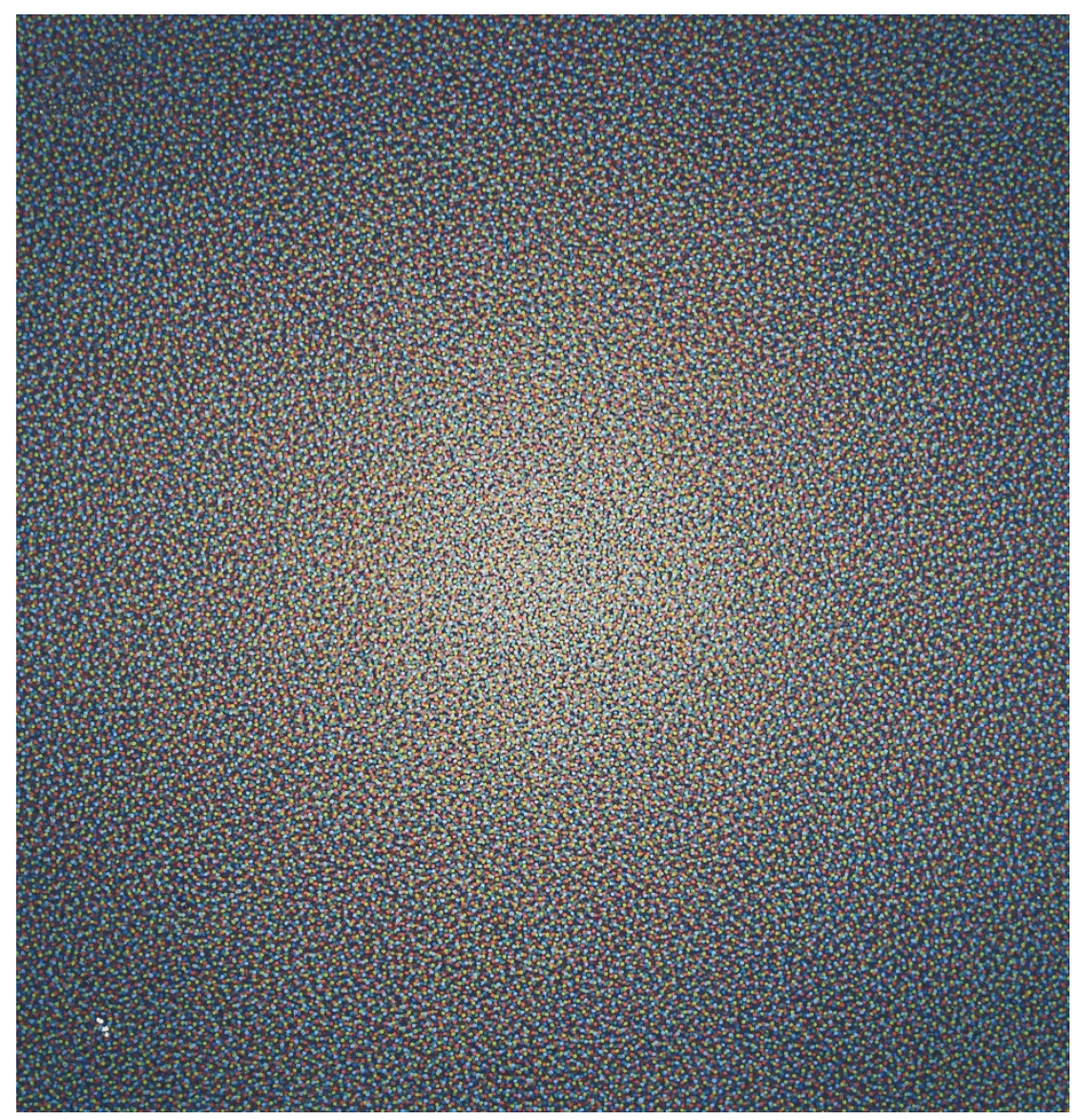

Figure 10.

Unified Field, 1980, Oil on Canvas, 30" x 30", Alexandre Gallery CSally Hazelet Drummond, courtesy Alexandre Gallery, New York 


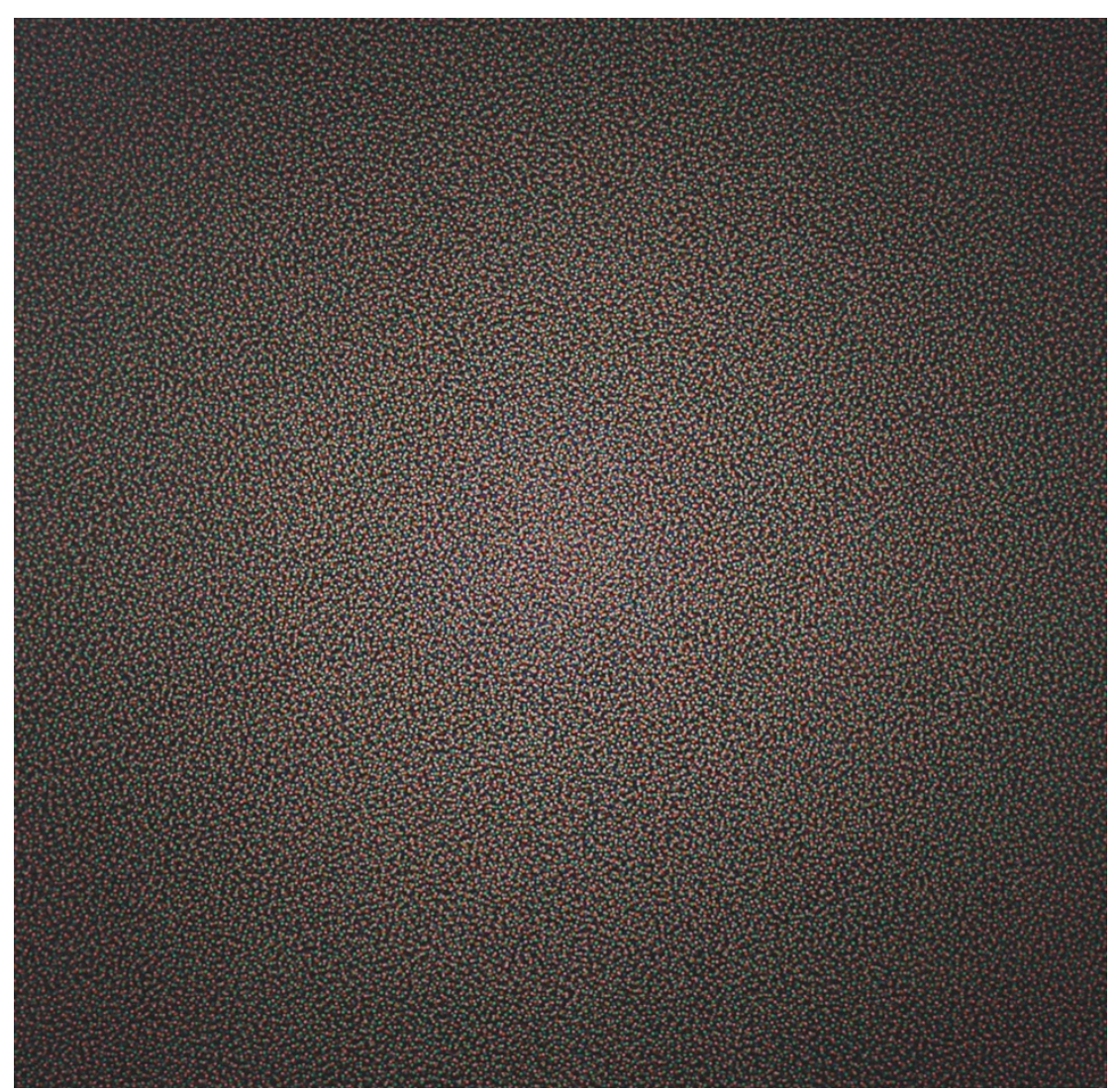

Figure 11.

Daisy Newman, 1984-1985, Oil on Canvas, 46" x 46", Alexandre Gallery CSally Hazelet Drummond, courtesy Alexandre Gallery, New York 


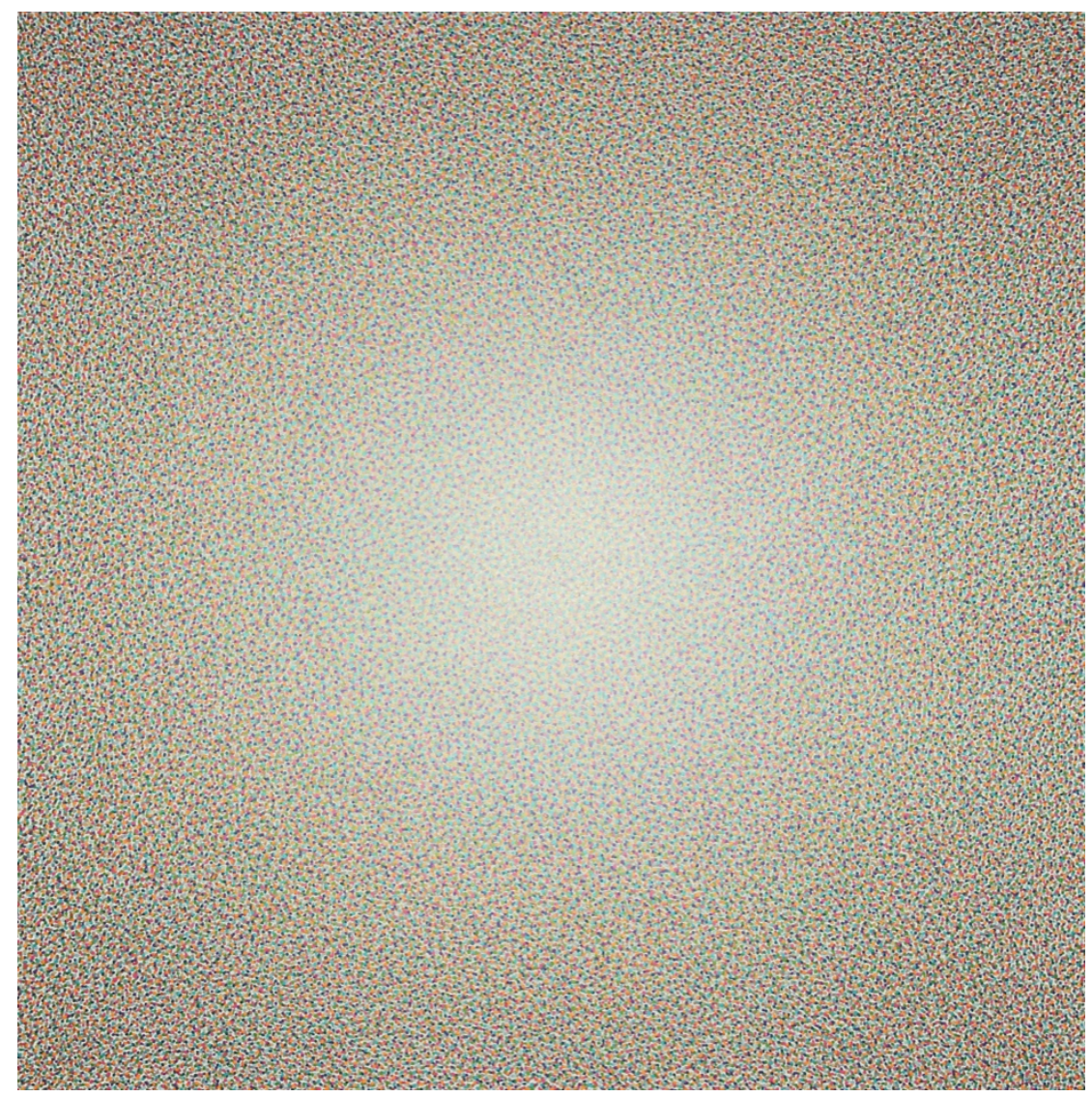

Figure 12.

No Separation, 1991, Oil on Canvas, 36" x 36", Alexandre Gallery (C) Sally Hazelet Drummond, courtesy Alexandre Gallery, New York 


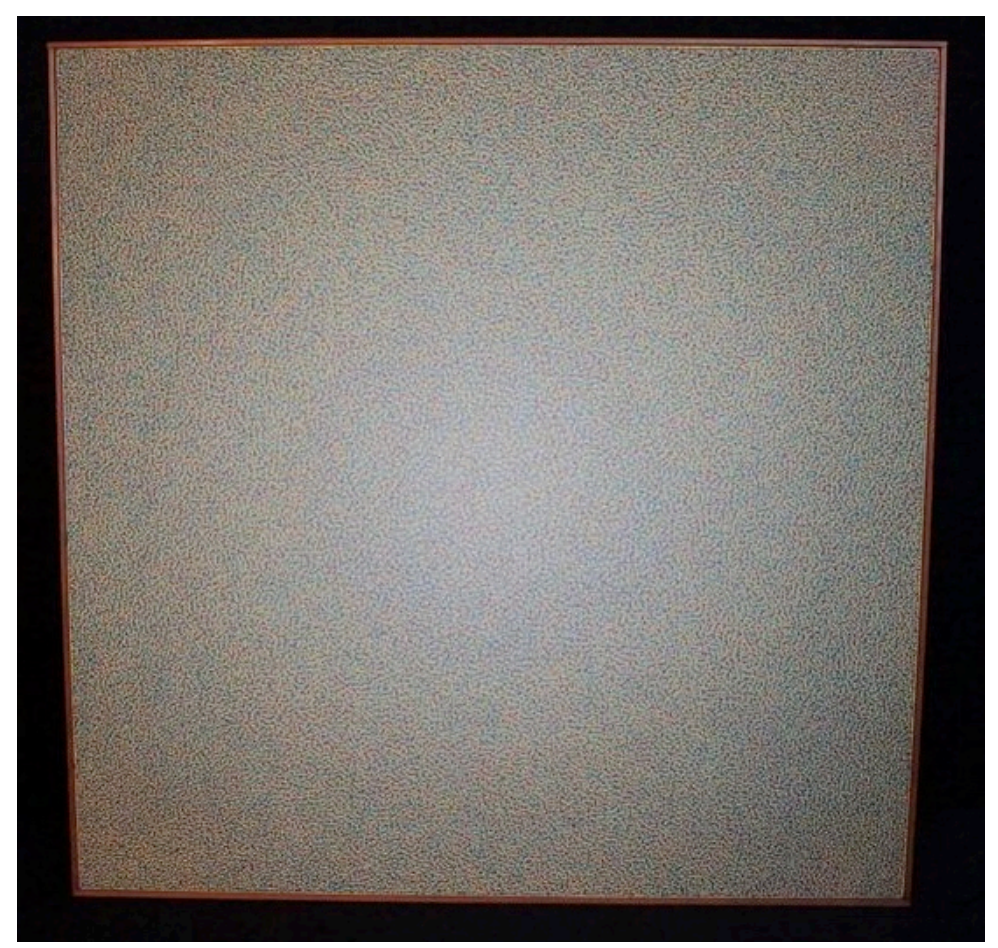

Figure 13.

Morning, 1997, Oil on Canvas, 30" x 30", Collection of Craig W. Clark 


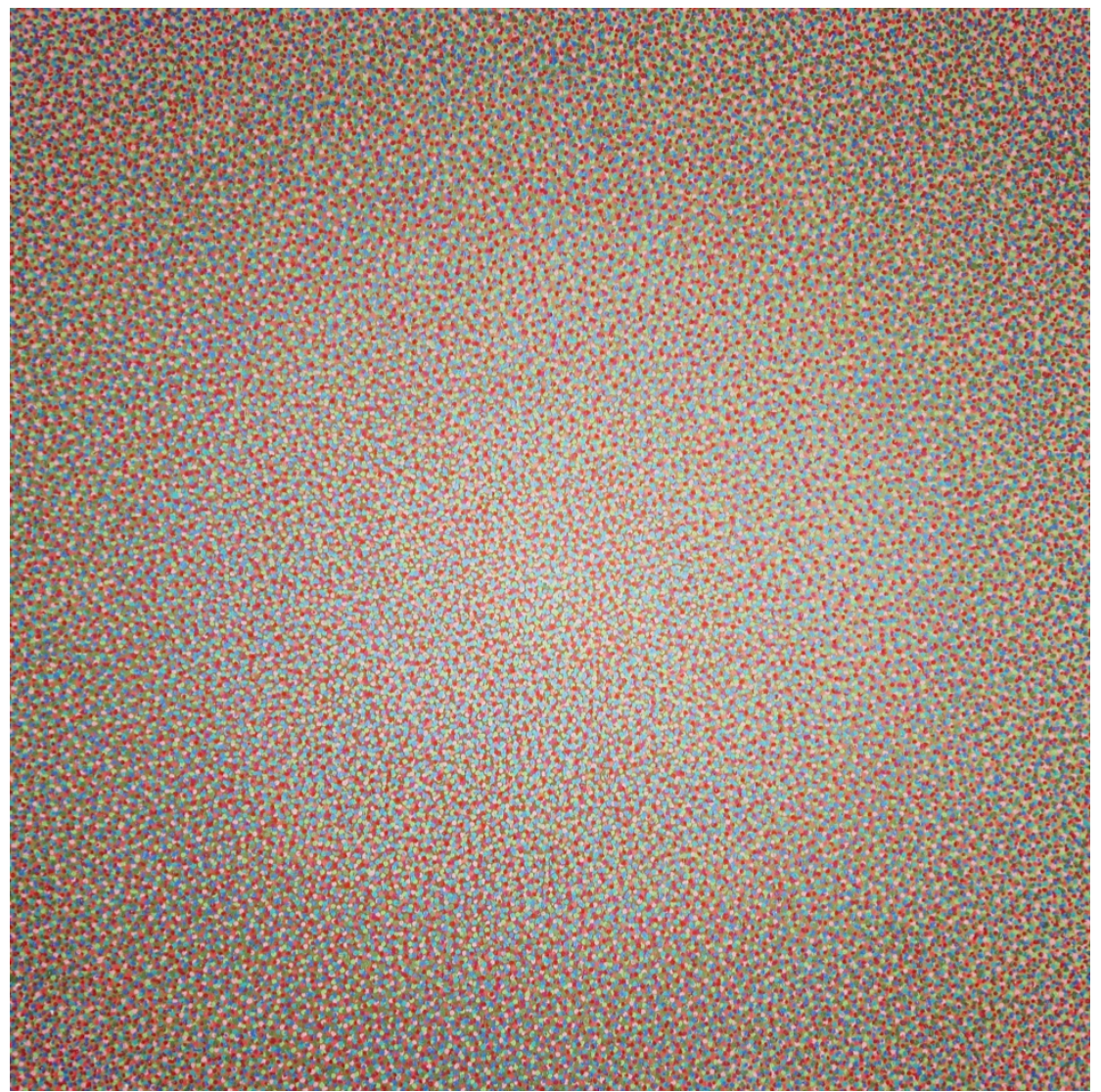

Figure 14.

Untitled (Gold Leaf), 2010, Oil on Canvas, 24" x 24", Alexandre Gallery CSally Hazelet Drummond, courtesy Alexandre Gallery, New York 


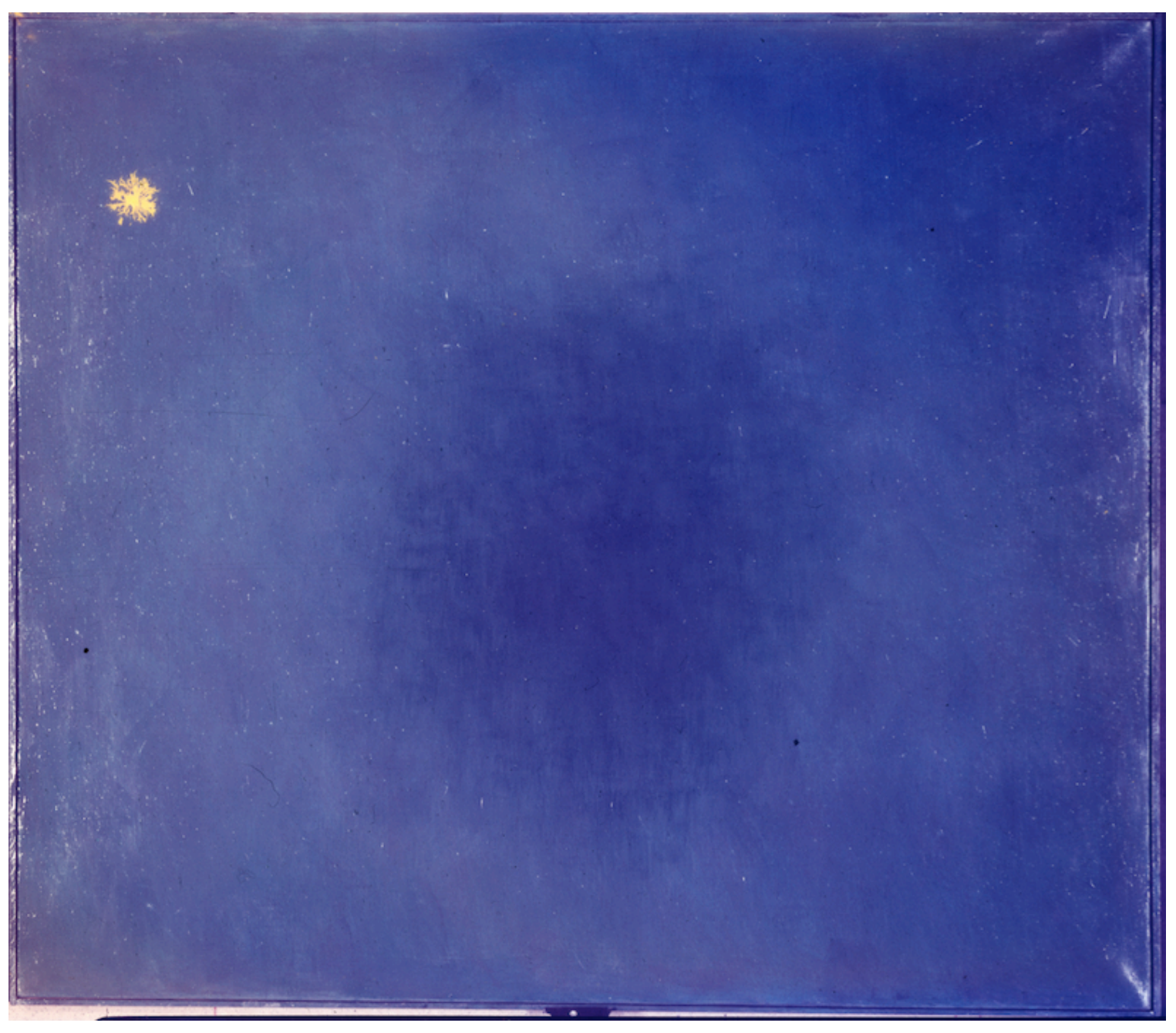

Figure 15.

Blue Painting, 1957, Oil on Canvas, 46" x 40" Slide Reproduced from the film found in Sally Hazelet Drummond Papers

Note that the flaw in the top left corner was from damage from the slide and was not part of the original painting 


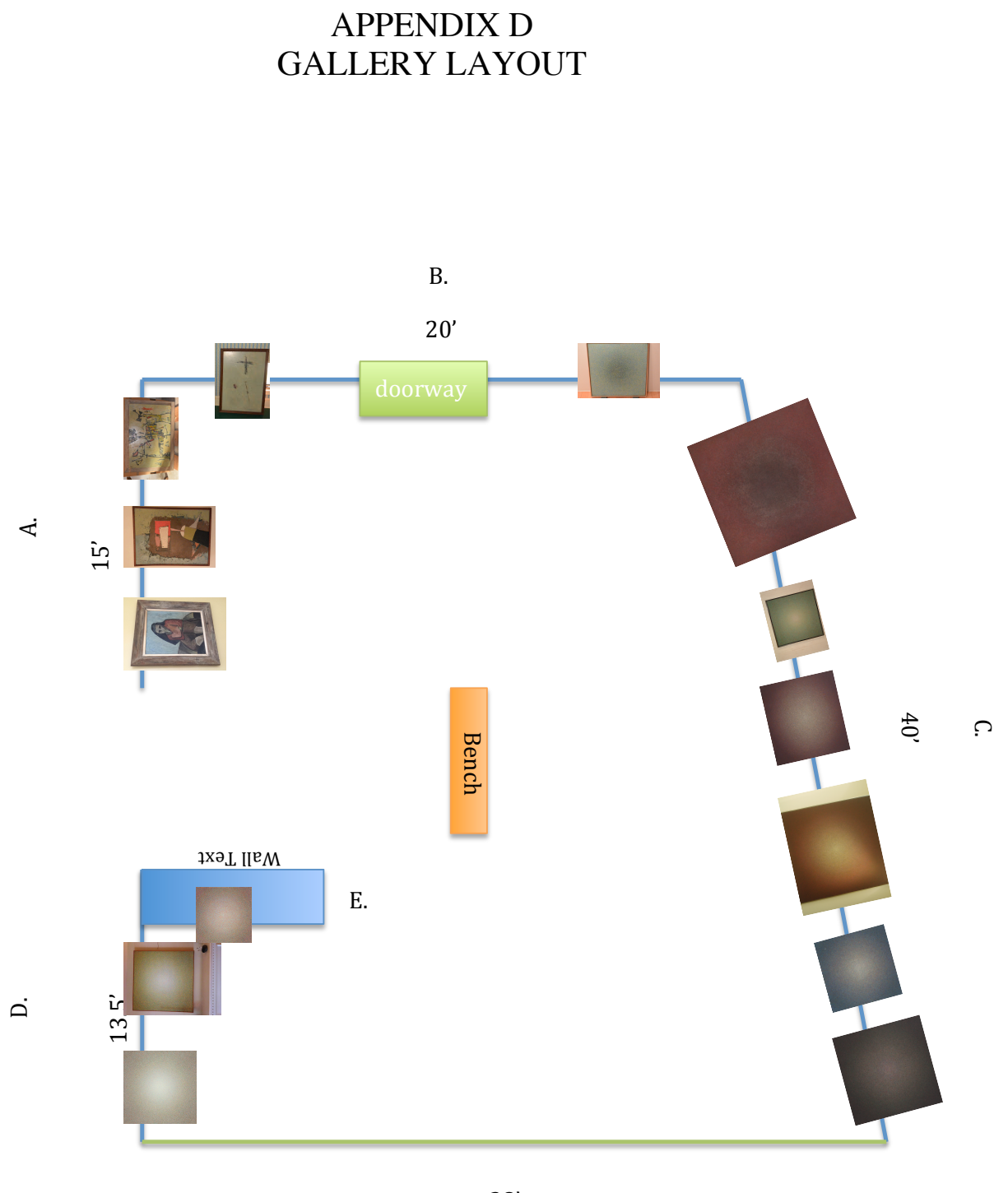

28' 
APPENDIX E

ICONOCLASTIC FERVOR WALL BY WALL

Gallery X, Schneider Hall Galleries, Hite Art Institute

From left to right

A.

1. Girl Sitting, 20" x24", c.1940s, John Clark LOAN LOU

2. Girl in a Doorway, 18"x24", 1949, Sally Hazelet Drummond LOAN

GERMANTOWN

3. Magician, 48"x32", 1951, Sally Hazelet Drummond LOAN

\section{GERMANTOWN}

B. 1. Untitled, 24" x 36", c. 1950s, Sally Hazelet Drummond LOAN GERMANTOWN

2. Bluebird, 24"x24", 1960, Alexandre Gallery LOAN NYC

C. 1. Heart of Iron, 60"x60", c.1960, Alexandre Gallery LOAN NYC

2. A Simple Arrangement, 18 " 18 ", 1969, John Clark LOAN LOU

3. Union Place, 40" $\times 40 ", 1978$, Alexandre Gallery LOAN NYC

4. Night Flight, 50"x50", 1978, University of Louisville Collections

5. Unified Field, 30"x30", 1980, Alexandre Gallery LOAN NYC

6. Daisy Newman, 46"x46", 1984-1985, Alexandre Gallery LOAN NYC

D. 1. No Separation, 36" $\times 36 ", 1991$, Alexandre Gallery LOAN NYC

2 Morning, 30"x30", 1997, C. Clark LOAN LOU

E. 1. Untitled (Gold Leaf), 24"x24", 2010, Alexandre Gallery LOAN NYC

\section{Loan Totals}

Louisville Area 3

NYC 7

Germantown, NY 3 


\section{APPENDIX F \\ INTRODUCTORY TEXT}

Sally Hazelet Drummond is the first female to graduate from the Hite Art Institute, earning a master's in painting in 1952. During her study at the University of Louisville she explored Abstract Expressionism, which started in the mid 1940s and was characterized by gestural or color-field paintings. Abstract Expressionism became the first American style to become an international movement. In 1953 Drummond joined the epicenter of the movement in New York City as a member of the Tanager Gallery, one of the leading Tenth Street artists' co-ops. In the midst of figures such as Willem De Kooning, Ad Reinhardt and Mark Rothko, Drummond refined her work into a simplified, uniquely personal, contemplative style that she continued to develop over the course of her life.

Drummond described Abstract Expressionism as a kind of iconoclastic fervor. While history has remembered the style as being characterized largely by wall sized canvases swabbed with gestural marks of the artists or huge fields of color, re-assessment today allows for a much larger perspective that encompasses the avant-gardism of the movement. Drummond continued the iconoclasm of the early abstract expressionists by rejecting these methods of working and creating her own definitive iteration.

Drummond's art and her journey into abstraction is also deserving of her description of the movement as an iconoclastic fervor. 
APPENDIX G

OBJECT LABELS

\section{Girl Sitting}

ca. 1940

Oil on Masonite

$24 " x$ 20"

Collection of Mr. and Mrs. John H Clark IV

This is the earliest work created by the artist and demonstrates the influence of Cubism on her work. The portrait is fairly conventional in its three-quarter view of a seated figure, paraphrasing popular portraits such as the Mona Lisa but flattens shapes and alters perspective, characteristics of Cubism.

\section{Girl in a Doorway}

1949

Oil on Canvas

$24 " x$ 18"

Collection of the Artist

Compared to the previous image, Girl in a Doorway demonstrates increased abstraction. While the title implies a figure, the image is far less realistic than Girl Sitting. Brushstrokes become almost sculptural in their application and convey a sense of motion, typical of gestural Abstract Expressionism. 


\section{Magician}

1951

Lacquer on Gessoed Masonite

$32 " x$ 48"

Collection of the Artist

Magician was created during Drummond's graduate study at the University of Louisville. The geometric shapes only hint at a figure, purportedly a scene of a magician. This work was painted using lacquer paint, which dried quickly as opposed to the oil paints that Drummond used previously. Abstract Expressionism relied on spontaneous gestures of the artist, making the medium of lacquer paint highly appealing for Drummond and other Abstract Expressionists.

\section{Untitled}

ca. 1952

Lacquer on Gessoed Masonite

$36 " x 24 "$

Collection of the Artist

This painting was created the same year that Drummond graduated from the University of Louisville with a Master's in Painting. Untitled is typical of gestural Abstract Expressionism in its use of primarily black and white coloring and its emphasis on abstract forms created intuitively. While there is no recognizable subject, Untitled conveys emotions through the layering of shapes, colors, and brushstrokes. 


\section{Bluebird}

1960

Oil on Canvas

$24 " x 24 "$

Courtesy of Alexandre Gallery

Drummond pioneered her use of dots after seeing a retrospective of the pointillist Georges Seurat at the Museum of Modern Art in 1958. Prior to her use of dots, Drummond was creating monochromatic fields of color with darker central cores, but maintains that she was never satisfied with the result. Describing the addition of dots, Drummond indicated that they added a sense of energy that the earlier paintings were missing.

\section{Heart of Iron}

ca. 1960

Oil on Canvas

$60 " \times 60 "$

Courtesy of Alexandre Gallery

Drummond's art straddles the two differing approaches within Abstract Expressionism, gestural and color-field. The application of dots are indicative of the artist's touch, or gesture but the largely monochromatic canvases also move toward the color-field style. In marrying the two styles, Drummond created her own distinctive method, one that is iconoclastic, in that it follows neither approach directly. 


\section{A Simple Arrangement}

1969

Oil on Canvas

$18 " x$ 18"

Collection of Mr. and Mrs. John H. Clark IV

In the late sixties, at the suggestion of fellow female Tanager Gallery member Lois Dodd, Drummond started creating paintings with light centers. Drummond states that originally she felt that the centers should be dark, like an anchor, but after she experimented with lighter centers, the paintings became about "exuberance" - that pulsate with energy (Interview with the Artist, 2015)

\section{Union Place}

1978

Oil on Canvas

$40 " x 40 "$

Courtesy of Alexandre Gallery

As Drummond continued to develop her pointillist technique, she began experimenting more with color, as can be seen in Union Place. In earlier works, such as Heart of Iron, there are fewer colors than in this work which features blues, yellows, greens, reds and pinks. Still, from a distance, the canvas appears to be almost entirely purple. Only after closer inspection can the full range of colors be seen, serving for her as a metaphor for the interconnectedness of life itself. 


\title{
Night Flight
}

1978

Oil on Canvas

$50 " x$ 50"

Night Flight is one of the larger paintings Drummond created but, like her other works, was still painted on a traditional easel. Unlike much of the wall-sized canvases created by other Abstract Expressionists, Drummond's smaller scale offered an antithesis to the notion that grand scale meant great art.

\section{Unified Field}

1980

Oil on Canvas

$30 " \times 30 "$

Courtesy of Alexandre Gallery

\begin{abstract}
Expressionists were often viewed by the public as lone artistic geniuses but the movement itself was highly centered on community and artistic interchange. In contrast to the rugged individualism stereotypically portrayed by abstract expressionists, Drummond's art, as implied by the title Unified Field, stressed interconnectedness and community through their careful application of dots.
\end{abstract}




\section{Daisy Newman}

1984-1985

Oil on Canvas

$46 " x$ 46"

Courtesy of Alexandre Gallery

In contrast to much of the spontaneity often associated with Abstract Expressionism, Drummond's artistic process was deliberate and timeconsuming. Even though she worked full-time as an artist, Drummond typically only completed 2-3 paintings a year. Each dot was applied by hand after great consideration, a stark contrast to the feverish artistic process of that is apparent in the work of many abstract expressionists.

\section{No Separation}

1991

Oil on Canvas

$36 " \times 36 "$

Courtesy of Alexandre Gallery

In spite of the emphasis on individualism and machismo in the public image of much of Abstract Expressionism, artists, like Drummond, incorporated spirituality in their art. When asked to describe her art, Drummond says that her work is 'contemplative.' Many viewers sense spiritual content in her work - as implied in the title, No Separation. 


\section{Morning}

1997

Oil on Canvas

$30 " x$ 30"

Collection of Craig W. Clark

Morning, suggests dawn, or new beginnings - a fitting description for Drummond's own artistic style. While Abstract Expressionism began as a movement that sought to destroy conventions and push the boundaries of art, the movement became restrictive in its own right. Drummond's own style was a means of once again incorporating an iconoclastic spirit that so initially attracted her to the work of early abstract expressionists.

\section{Untitled (Gold Leaf)}

2010

Oil on Canvas

$24 " x 24 "$

Courtesy of Alexandre Gallery

Untitled (Gold Leaf) is one of the last works Drummond worked on before retiring. The incorporation of faux gold leaf adds another layer of radiance through the added reflection of light bouncing off of the gold paper. This new addition draws on a long tradition of gold-leaf throughout art history and works to place Drummond's art in dialogue with great art across time. 


\section{APPENDIX H BROCHURE TEXT}

Sally Hazelet Drummond is the first female to graduate from the Hite Art Institute, earning a master's in painting in 1952. During her study at the University of Louisville she explored Abstract Expressionism, which started in the mid 1940s and was characterized by gestural or color-field paintings. Abstract Expressionism became the first American style to become an international movement. In 1953 Drummond joined the epicenter of the movement in New York City as a member of the Tanager Gallery, one of the leading Tenth Street artists' co-ops. In the midst of figures such as Willem De Kooning, Ad Reinhardt and Mark Rothko, Drummond refined her work into a simplified, uniquely personal, contemplative style that she continued to develop over the course of her life.

While Drummond's art has been labeled as belonging to various genres ranging from Neo-Pointillism to Op-Art, the thesis of this exhibition is that her work is firmly rooted in Abstract Expressionism and is best understood within this context.

Drummond described Abstract Expressionism as a kind of iconoclastic fervor. While history has remembered the style as being characterized largely by wall sized canvases swabbed with gestural marks of the artists or huge fields of color, re-assessment today allows for a much larger perspective that encompasses the avant-gardism of the movement. Drummond continued the iconoclasm of the early abstract expressionists by rejecting these methods of working and creating her own definitive iteration.

Drummond's artistic career from her graduate days to the present has been a deepening exploration into her personal understanding of abstract expressionist practice. Drummond's views on spirituality and community serve as a foil to much of the machismo and individualist psychology of the abstract expressionist artists. Additionally, Drummond's use of easel scale, unrestrained use of color and deliberate art making process offer a reframing of the accepted tenets of Abstract Expressionism. Drummond's art and her journey into abstraction is also deserving of her description of the movement as an iconoclastic fervor. 


\section{APPENDIX I \\ QUOTES BY SALLY HAZELET DRUMMOND}

The following is a series of quotations that were included in the exhibition, Iconoclastic Fervor: Sally Hazelet Drummond's Road to Abstraction with the quotes placed above the artworks. All of the quotations are by Sally Hazelet Drummond.

"A kind of iconoclastic fervor describes these paintings-Interweaving, pulsing, kinetic lines, shapes and color intuitively released" - 1957, World of Silent Painting

"My vision is of an art that declares sensed reality in the purest and simplest terms - the total painting as the image - silent, emphatic and radiant." -ca. 1965, artists statement

"There is no foreground, no background .... Just a sensation and affirmation of oneness." - 1996, "Group Show" article 


\section{APPENDIX J \\ CURATORIAL ESSAY}

The following is the essay that was written for the exhibition catalogue, Iconoclastic Fervor: Sally Hazelet Drummond's Road to Abstraction

\section{Sally Hazelet Drummond's Iconoclastic Spirit}

This exhibition is a celebration of the art and life of Sally Hazelet Drummond. It also illustrates how Abstract Expressionism is an ideology as well as an historical art movement. The exhibition demonstrates how Drummond evolved beyond this artistic style into a method of working that prefigures many important developments in the latter $20^{\text {th }}$ century.

\section{PREFACE}

Abstract Expressionism is an art movement that flourished between 1945-1962. Since Sally Hazelet Drummond lived and worked in New York following her graduate studies at the University of Louisville, the focus of this discussion is primarily on the movement in New York, however there were corollary iterations, such as West Coast Abstract Expressionism, that also presented methods of artmaking that are similar to Drummond's development of alternatives to the standard individualistic expressionism usually associated with the style. Drawing inspiration out of previous art movements, namely Cubism, Surrealism, and German Expressionism, the movement combined Existentialist and Freudian philosophy to push the boundaries of modern art. Considered to be the first major American contribution to art history, Abstract Expressionism also marks the rise of the art critic. More than ever before, the opinions of art critics were sought out and listened to by the artists, the art establishment and the general public. Chief among these critics was Clement Greenberg, who was the first to exalt the movement and champion artists such as Jackson Pollock and Willem de Kooning, but other important writers included Harold Rosenberg, Thomas Hess, Barbara Rose and Irving Sandler. (1.)

What is now known as Abstract Expressionism was at the time known by several different titles: Action Painting,(2.) American-Type,(3.) Abstract-Individualism,(4.) to name a few, which demonstrates the multiplicity of understandings about what exactly constituted the new movement. New York abstract expressionists primarily lived, worked, painted and exhibited in a relatively small geographic area around $57^{\text {th }}$ Street and, later, $10^{\text {th }}$ Street. Artists and critics visited each other's studios, attended gallery openings and met weekly as groups to discuss contemporary art theory. Abstract Expressionism is often split chronologically into two segments: first and secondgeneration. The first-generation abstract expressionists matured during the WPA era and pioneered their new styles in the middle forties. This generation received the brunt of initial criticism and rejection and paved the way for acceptance of second-generation artists' subsequently and the styles that followed the first-generation of abstract 
expressionists.(5.) A wide range of artists who came to work in New York in the 1950s typifies the second-generation. They assembled themselves in schools and artists' co-ops along $10^{\text {th }}$ Street and were all influenced by the work of the first-generation abstract expressionists who excited them with a newfound freedom of expression. (6.)

Traditionally, Abstract Expressionism has been understood to include two modes or approaches, 'gestural' and 'color-field'. However, as implied by the variety of names by which the movement was originally known, the moniker Abstract Expressionism is hardly exact. The art was not always totally abstract nor expressionistic in the strictest sense of the words. While subject matters were generally abstracted to some degree, meaning that they were not 'true-to-life' depictions, many abstract expressionists, such as Willem de Kooning, still painted recognizable images. Expressionism held the implication that the work was painted to evoke emotions but the tone of those emotional responses varied widely. Situated within this nominal style were different methods of working that came to be called 'gestural' and 'color-field.' Gestural Abstract Expressionism includes art in which the process is evident in the final product, i.e. the gesture of the artist's application of paint is conjured in looking at the image-whether through paint pouring, as in the work of Jackson Pollock, or in heavy brushstrokes and impasto as in the work of Willem de Kooning. Abstract expressionists who worked in the color-field style often watered down their paints to create stains or washes that were then applied to the canvas without the obvious marking of the gestural approach to create color-studies or fields that became the sole subject matter. The art of Mark Rothko and Helen Frankenthaler are typical examples of color-field Abstract Expressionism. While gestural painting preceded color-field, both styles loosely embody the notion of abstraction and expressionism. (7.)

Like most historical categorizations, our understanding of the movement now is shaped by stereotypes formed by generalizations used in vernacular language over time. In the case of Abstract Expressionism, this is largely due to the biases of popular art critics who shaped initial ideas about the style, principally Clement Greenberg. For Greenberg, abstract expressionist painting had to be large in scale, 'rough', emphasize the flatness of the canvas and, at least for 'gestural' painters, eschew color.(8.) Greenberg and others advocated a 'lack of refinement' and exalted spontaneity and improvisation in the artistic process. In the popular culture, the abstract-expressionist artist was characterized as rugged, masculine, embodying individualism.(9.) However, these preconceptions constricted the definition of abstract expressionism and left many artists, such as Sally Hazelet Drummond, who did not agree with each of these tenants, out of consideration for inclusion in the conversation about what was the most progressive and advanced in contemporary art. Moreover, the connotation of the rugged individual artist working feverishly at the canvas created a strong sense of machismo in Abstract Expressionism. Artists, such as Drummond, who valued community and spirituality and whose work was deliberately created on an easel, or personal, scale rather than the 'herioic' size of artists such as Pollock or Still and were exploring an unrestrained use of color contradicted traditional, Greenbergian, notions of abstract expressionism. 


\section{ALTERNATIVES TO CONVENTIONAL ABSTRACT EXPRESSIONISM}

In contrast to Greenberg, critic and writer Irving Sandler advocated for a historical revision of the movement. Sandler was a contemporary of the second-generation Abstract Expressionists. He was the manager of the Tanager Gallery, the $10^{\text {th }}$ Street artists' co-op that Sally Hazelet Drummond was a member of, from 1956 to 1959. (10.) He is also one of the only major art critics to write about her art. In an exhibition Drummond had in 1984 at Artist Space, Sandler writes about the historical tendency to only remember conventional abstract expressionists, namely those whose work was 'gestural' and could even be described as violent, such as Willem de Kooning's Women Series. Expanding on this notion, Irving remarks: "In fact, fifties painting was far more varied than it is now remembered to have been. And if there was violence, there was also lyricism - and contemplation, none quieter than Drummond's abstract images." (11.)

\section{SALLY HAZELET DRUMMOND’S ALTERNATE WAY}

In this exhibition, looking at the work of Sally Hazelet Drummond, the viewer can begin to re-examine the conventional understanding of Abstract Expressionism and widen the sense of the movement and its impact. As Drummond's interview and her texts indicate, her path to abstraction was initially fairly conventional in that it began with a sense of liberation that the first-generation of abstract expressionist artists provided for the whole succeeding generation of followers. Like many of the leading abstract expressionists, the artist started painting figuratively. She describes her early taste in art as 'parochial'. Included in the exhibition is Girl Sitting from c. 1940 which is an example of her early work. The work shows the influence of cubism and perhaps some sense of earlier $20^{\text {th }}$ century expressionism but is far from being abstract expressionistic. Recalling a 1947 visit to the Whitney Museum, the artist describes her early dislike of abstract art, "I can not help feeling that when the artist ceases to think even in terms of known recognizable objects that his finished canvases represent merely a conversation between himself...period."(12.) Drummond goes on to state that for her in 1947 abstract, what she called non-objective, art was "terribly uninteresting." (13.) Gradually, she started studying and being influenced by avant-garde artists such as Henri Matisse, Edvaard Munch, Paul Klee and even Willem de Kooning.(14.) Girl in a Doorway, 1949, and Magician, 1951 show the increasing influence of avant-gardism and initial contact with Abstract Expressionism in her art. In her 1952 master's thesis at the University of Louisville, Drummond outlines her changing perspective and preference for a more abstract expressionistic art. For Drummond, in 1947, the lack of recognizable subject matter was alienating to the viewer who had no commonality or entry-point into understanding the work but it is apparent that her opinion had changed by the early 1950 s. By then, she seems to be in agreement with the first-generation of abstract expressionists, who saw the elimination of the subject matter as a means of elevating art. 
Without a subject to distract the viewer, the focus became solely on the formal elements of the art and the raw expression of the individual artist - its lines, shapes, colors and textures were universal archetypes and metaphors that were a democratizing measure for viewers in which little to no preconceived understanding was requisite (i.e. the viewer did not have to know the story of Sophocles' Antigone in order to understand the art - the feeling or emotion, 'expression, was conveyed through the abstract formal elements of the work). Her 1952 thesis goes on to trace her journey into abstraction; Drummond recounts a time in which after painting a vase of flowers she began to add white paint until the entire canvas was covered with the exception of small areas and the original image was no longer visible. Drummond had veered into Abstract Expressionism. (15.) Upon the completion of her master's degree in painting, Drummond's work had become abstract expressionistic in the traditional sense, as can be seen in works such as Untitled, c. 1952. There is no recognizable subject matter, there is little color in the work and the presence of the gesture is evident.

When Drummond joined the Tanager Gallery in New York in 1953, her work was similar to Untitled. The artist describes her artistic process and intent in her 1952 text on page \#\#\#\#\#. Under the influence of the $10^{\text {th }}$ Street scene, Drummond's work continued to evolve into monochromatic studies with only a hint of an image in the center of the canvas. Drummond describes these works in the text titled the "World of Silent Painting" (see page \#\#\#\#\# in this catalogue): "My present paintings each have a single color uninterrupted by line or shape. The color is laid on in a series of thin glazes restricted to subtle variations within the narrow limits of the dominating color. In the center of each painting is a concentration or deepening of tone, which serves as a focus or core of the painting."(16.) For Drummond, the departure from the 'gestural' style to the 'color-field' style was a means of leaving behind much of the individualism and chance for what she calls a 'World of Silent Painting,' the quieter and lyrical abstract expressionism Sandler wrote about in 1984.

While none of these early monochromatic canvases exist, a slide of work in this vein has been reproduced on page \#\#\#\#\#. The relationship of this work to her mature style is evident in the use of all over patterning and the central core imagery. As Drummond outlined in her gallery talk at Rollins College in 1989 she discovered pointillism in 1958 after seeing a retrospective of pointillist Georges Seurat at the Museum of Modern Art. Inspired by his use of dots "in giving a sense of volume and energy to simple shapes."(17.) Drummond goes on to explain that this was the mechanism she had been looking for to activate her earlier canvases and that she started experimenting with the method in Bluebird, 1960, and Heart of Iron, c. 1960. These works show some early results of the artist's application of pointillism. These dots are larger and further apart than in later works indicating that she continued to refine her pointillist technique for the rest of her career.

The last major change to take place in Drummond's art is the changing of the center core from dark to light. Also outlined in her 1989 gallery talk (PAGE \#\#\#\#) the artist muses, “In the 1960's my paintings had a dark center. I think I felt that the core should have 
weight, that the center needed to be anchored down." However, after the suggestion of Lois Dodd, a fellow Tanager Gallery member, Drummond began experimenting with a light center. In her words, "it gradually became, not a matter of anchoring but of searching for a kind of radiance."(18.) All of the exhibited works from A Simple Arrangement, 1969, to Untitled (Gold Leaf), 2010 have light centers. While Drummond experienced major changes in her pictorial style early on in her journey to abstraction, the artist describes her venture from her early abstractions to color-field painting to the contemplative and quiet radiant style that she discovered in the early 1960's. In this "narrow path" (19.) she established her personal working identity and a consistent oeuvre.

\section{DRUMMOND'S ICONOCLASM}

A deeper look at a single work of Drummond's oeuvre is revealing. In No Separation from 1991, many of the affinities and departures from traditional abstract expressionism become apparent. Her independence and determination to follow her own course become apparent when approaching the canvas from a distance: the scale is unassertive at 36 " 36 " compared to the 'heroic' scale of many abstract expressionist works. At first, the painting appears to be an off-white color with some variations of color. Upon closer examination, a myriad of colors become apparent--- the blues, purples, pinks, yellows, greens in several hues placed one right next to another are not the subdued palate of conventional 'gestural' painters. Even while this bold use of color nods to the work of 'color-field' painters who were emboldened by strong hues, the scale and variety of colors applied without washes in petite dots is unique to Drummond's work. Ultimately however, the dots themselves are an affirmation of the ideology of the gesture of abstract expressionists but their deliberate application contradicts what the artist called "the bacchanalian orgy of paint throwing, dripping and splashing"(20) in her 1989 gallery talk. When studying No Separation it becomes apparent that the profusion of the carefully placed and carefully chosen colors of her dots as they trace and build the image dot by dot, as well as the overall nature of her composition, guides the viewer to a metaphorical understanding of the artist's view of the seemingly limitless connections within the piece - and life. The canvas was painted methodically, again challenging the conventional notions of the feverish abstract expressionist. This approach also requires more from the viewer; as opposed to the brashness of many conventional abstract expressionist works, Drummond's art necessitates a more contemplative approach. No Separation, while one work out of many, typifies how Sally Hazelet Drummond disputes and expands the territory of Abstract Expressionism.

Abstract Expressionism embodied an iconoclastic spirit and pushed the boundaries of artistic freedom. It was this impetus that propelled many second-generation abstract expressionists, including Sally Hazelet Drummond. However, the historical tendency to categorize and generalize the movement has ultimately led to a narrower conception of Abstract Expressionism than what actually transpired in artists' studios. For an art that was intended to simplify and universalize the art experience for the individual, to be all 
about primal connections, as Drummond stated in the included gallery talk, her work refutes the notion of the lone artistic genius and rugged individualist and serves instead as a visual paradigm of carefully considered and placed individual dots building an overall composition that echoes and reflects the artistic $10^{\text {th }}$ Street community in which she lived, worked and developed her signature style.(21.) Her 'quieter' abstraction achieved the artist's goals of creating a contemplative environment for the viewer. While Drummond has been described as anticipating several succeeding genres such as minimalism and opart, she is, in fact, a Second-Generation Abstract Expressionist - a continuing, determined, subversive freethinker. Drummond once described Abstract Expressionism as having a type of "iconoclastic fervor"(22.) in its desire to actively challenge and create a new art form from its predecessors but her own ability to challenge the popular conventions of the movement through her long career of artmaking is in itself a tremendous example of iconoclastic fervor.

Catalogue Essay Citations

1. Greenberg, Clement .1965. "America Takes the Lead” in John O'Brians Clement Greenberg: The Collected Essays and Criticism. Chicago: University of Chicago Press.

And

Sandler, Irving. 2009. Abstract Expressionism and the American Experience : A Reevaluation. Mission critical series; Mission critical series. Lenox Mass.: Hard Press Editions.

2. Rosenberg, Harold. 1952. "The American Action Painters" in The Tradition of the New. London: Thames and Hud.

3. Greenberg, Clement. 1955. "American-Type Painting” in Art and Culture: Critical Essays. Boston: Beacon Press.

4. Goosen, E.C.. "Rothko: The Omnibus Image” in Art News, January 1961.

5. Wood, Paul. 1993. Modernism in Dispute: Art Since the Forties. Modern art--practices and debates; Modern art--practices and debates. New Haven: Yale University Press, in association with the Open University, London, 9-32.

And

Polcari, Stephen. 1991. Abstract Expressionism and the Modern Experience. Cambridge England: Cambridge University Press, 4-16. 
6. Sandler, Irving. 2009. Abstract Expressionism and the American Experience : A Reevaluation. Mission critical series; Mission critical series. Lenox Mass.: Hard Press Editions.

And

Sandler, Irving. 1978. The New York School : The Painters and Sculptors of the Fifties. Icon editions; Icon editions. New York: Harper \& Row.

And

Puniello, Françoise S., and Halina. Rusak. 1996. Abstract Expressionist Women Painters: An Annotated Bibliography: Elaine De Kooning, Helen Frankenthaler, Grace Hartigan, Lee Krasner, Joan Mitchell, Ethel Schwabacher. Lanham, Md.: Scarecrow Press, VII.

7. Sandler, Irving. 1970. The Triumph of American Painting: A History of Abstract Expressionism. New York: Praeger.

And

Sandler, Irving. 1978. The New York School: The Painters and Sculptors of the Fifties. Icon editions; Icon editions. New York: Harper \& Row.

And

Sandler, Irving. 2009. Abstract Expressionism and the American Experience : A Reevaluation. Mission critical series; Mission critical series. Lenox Mass.: Hard Press Editions.

8. See Greenberg, Clement. 1939. "Avant-Garde and Kitsch" in Art and Culture: Critical Essays. Boston: Beacon Press.

And

Greenberg, Clement. 1955. "American-Type Painting” in Art and Culture: Critical Essays. Boston: Beacon Press.

And

Greenberg, Clement. 1962. “After Abstract Expressionism” in John O’Brian. 1986. The Collected Essays and Criticism. Chicago: University of Chicago Press. 
9. Greenberg, Clement. 1953. "Symposium: Is the French Avant-Garde Overrated?" in John O'Brian. 1986. The Collected Essays and Criticism. Chicago: University of Chicago Press.

\section{AND}

Sandler, Irving. 2009. Abstract Expressionism and the American Experience : A Reevaluation. Mission critical series; Mission critical series. Lenox Mass.: Hard Press Editions, 11-12.

10. Sandler, Irving. 2006. From Avant-Garde to Pluralism: An On-The-Spot History. Lenox, MA: Hard Press Editions, 33.

11. Sandler, Irving. 1984. "Sally Hazelet Drummond." Exhibition Handout, Sally Hazelet Drummond: February 25- March 24. Artists Space Gallery, New York.

12. Hazelet, Sally. 1952. "A Commentary on my Painting." Master's thesis, University of Louisville, 6.

13. Ibid.

14. Drummond, Sally Hazelet. 1989. “Gallery Talk for Rollins College.” Artist's papers.

15. Hazelet, Sally. 1952. "A Commentary on my Painting." Master's thesis, University of Louisville, 17.

16. Hazelet, Sally. "World of Silent Painting." In Arts in Louisville Magazine, September, 1957.

17. Drummond, Sally Hazelet. 1989. “Gallery Talk for Rollins College.” Artist's papers.

18. Ibid.

19. Ibid.

20. Ibid.

21. Ibid.

22. Hazelet, Sally. 1952. "A Commentary on my Painting." Master's thesis, University of Louisville, 14. 


\title{
APPENDIX K EXHIBITION EVALUATION FORM
}

\author{
Iconoclastic Fervor: Sally Hazelet Drummond's Road to Abstraction \\ Exhibition Evaluation
}

Date of visit:

What, if anything, did you get from your visit today?

Do you have an increased understanding of Abstract Expressionism or of the artist, Sally Hazelet Drummond?

Was your visit a positive experience?

Do you feel the exhibition was professional in its presentation?

General comments or questions:

To continue to the conversation-- contact the curator at hillary.sullivan@louisville.edu

\section{Iconoclastic Fervor: Sally Hazelet Drummond's Road to Abstraction Exhibition Evaluation}

Date of visit:

What, if anything, did you get from your visit today?

Do you have an increased understanding of Abstract Expressionism or of the artist, Sally Hazelet Drummond?

Was your visit a positive experience?

Do you feel the exhibition was professional in its presentation?

General comments or questions:

To continue to the conversation-- contact the curator at hillary.sullivan@louisville.edu 


\section{APPENDIX L EXHIBITION PRESS RELEASE}

\section{FOR IMMEDIATE RELEASE}

Iconoclastic Fervor: Sally Hazelet Drummond's Road to Abstraction

Thursday, November $19^{\text {th }}, 2015$ - Friday, December $18^{\text {th }}, 2015$

Curated by Hillary Sullivan, Master's Candidate, Critical and Curatorial Studies

Gallery X, Schneider Hall Galleries

2300 S. First Street Walk, Louisville, Kentucky 40208

Sally Hazelet Drummond is the first female to graduate from the Hite Art Institute with a master's degree in painting in 1952. During her study at the University of Louisville she explored Abstract Expressionism, which started in the mid 1940s that was characterized by gestural or color-field paintings. Abstract Expressionism became the first American style to become an international movement. In 1953 Drummond joined the epicenter of the movement in New York City as a member of the Tanager Gallery, one of the leading Tenth Street artists' co-ops. In the midst of figures such as Willem De Kooning, Ad Reinhardt and Mark Rothko, Drummond refined her style into the dotted starburst patterns that she continued to develop over the course of her life.

Drummond described the movement as a kind of iconoclastic fervor. While history has remembered Abstract Expressionism as being a definitive style characterized largely by wall sized canvases swabbed with gestural marks of the artists or huge fields of color, reassessment today allows for a much larger perspective that typifies the avant-gardism of the movement. Drummond continued the iconoclasm of the early abstract expressionists by rejecting these methods of working and created her own definitive iteration.

Drummond's artistic career from her graduate days to the present has been a deepening exploration into her personal understanding of abstract expressionist practice. Drummond's views on spirituality and community serve as a foil to much of the machismo and individualist psychology of the abstract expressionist artists. Additionally, Drummond's use of easel scale, unrestrained use of color and deliberate art making process offer a reframing of the accepted tenets of Abstract Expressionism. Drummond's art and her journey into abstraction is also deserving of her description of the movement, an iconoclastic fervor.

The exhibition of 14 works of art, ranging from the 1940s until 2010, is on display in Gallery $\mathrm{X}$ at the Schneider Hall Galleries from November $19^{\text {th }}$ until December $18^{\text {th }}, 2015$. An accompanying catalogue, Iconoclastic Fervor: Sally Hazelet Drummond's Road to Abstraction, is also available for purchase for $\$ 24.95$ from Hillary Sullivan at Hillary.sullivan@aol.com 


\section{APPENDIX M \\ INTERVIEW WITH THE ARTIST}

Interview with Sally Hazelet Drummond, Germantown, New York, Saturday, July $25^{\text {th }}$, 2015

Interviewer: Hillary Sullivan, HS

Interviewee: Sally Hazelet Drummond, SHD

Also in attendance: Craig Drummond, CD and John Clark, JC

\section{$\underline{\text { Session } 1}$}

HS: Today is July $25^{\text {th }}$. I'm here with Sally Hazelet Drummond. In attendance also jumping in and out will be Craig Drummond and John Clark. Sally do you want to introduce yourself or do you want me to introduce you?

SHD: You introduce me, cause my voice is so uncertain.

HS: Absolutely. Sally Hazelet Drummond, I'm here interviewing her because we are doing an exhibition, a retrospective, of her work in Louisville. She's the first female masters graduate from the Hite Art Institute. Graduated in 1952 and then continued on to have a fabulous career in New York. Worked at the Tanager Gallery which was an artist's co-op and then has worked independently ever since in abstract expressionism primarily. Sally, I'm just going to ask a few different questions; some of them are going to be personal, some of them are going to be about your thesis, some of them are going to be about specific works of art and then just proffer any other information that you think is important that you think we should know about.

SHD: Okay.

HS: So the first one is 'can you talk about how you got to abstraction?' When you started out painting, your work was figurative.

SHD: Yeah, then uh, well, let me see. You are always influenced by somebody or something. At least that's been my experience.

HS: So who were your influences?

SHD: Oh, see there's a mockingbird.

HS: That's beautiful. 
SHD: Mmm Hmm. Let me see. I uhh. Influences. Well. Influences.

HS: Well you started making pictures that were representative. You did portraits or landscapes or peoples or still lifes and then you started making objects that were more abstract.

SHD: Mmm Hmm.

HS: So how did you go from, that process, from making something recognizable to making something more cerebral?

SHD: Well you know, you are always influenced by somebody or by something and umm. I'm trying to think.

HS: Why did you go to art school in the beginning?

SHD: Oh. I didn't go to art school in the beginning because I had-I was just following along. Let me see.

HS: Did you always like making things growing up or was it something you found later?

SHD: I'd say it came later.

HS: Came later.

SHD: Yeah. Umm.

HS: Do you remember what you first started? Did you start drawing or painting or working in $3 \mathrm{D}$ ?

SHD: Ummm. Well I'm thinking. I can't remember really. Let me see. It started in New York and I was with, I joined a gallery. It was a co-operative gallery.

HS: When did you join the gallery?

SHD: When did I join the gallery?

HS: Is that the Tanager?

SHD: That's how I got to, uhh, let's see.

HS: What was it like to create in the gallery? Who were you in there with? You were in there with Lois...

SHD: Lois, ummm, I think Philip Pearlstein was there and umm, that was Philip. 
HS: Was it a supportive environment?

SHD: I don't know. What do you mean supportive?

HS: Well did you get along with people there?

SHD: Oh yeah.

HS: Yeah? Did everybody support each other's work? Or was there some friction in between styles?

SHD: No, there was no friction and my father supported it.

HS: Your father supported it?

SHD: Mmm Hmm. Yeah, he was a.. He was wonderful.

HS: Did he support you throughout your whole career or just once you got to New York?

SHD: Nope, my whole career.

HS: Good.

SHD: He supported it, I wouldn't say enthusiastically all the time but he supported it.

HS: Did he expect you to make a career out of it or did he think that it was a hobby initially?

SHD: Well I don't think he thought of it as a hobby, I never thought of it as a hobby.

HS: So you were serious from the get-go.

SHD: Yeah.

HS: Good. That's important. So you were in Tanager and it was artists-run so that's what was unconventional about that time is that the artists were operating the galleries as opposed to gallerists.

SHD: Yeah.

HS: So what was different about that environment?

SHD: From what? 
HS: From a traditional gallery setting where you have so much involvement of the art market put in and the expertise of art historians.

SHD: Yeah, ummm. Your question was how was it different than a traditional gallery?

HS: Yeah, that was a pretty unusual model for that time.

SHD: I guess so. It was...

HS: You and Lois were the only women in the gallery right?

SHD: Yeah.

HS: What was that like?

SHD: There was no conflict.

HS: There was no conflict, okay. Between you and her or between you and the other gentleman in the gallery?

SHD: Between the people in the gallery and also Lois and I. We were pals and umm..

HS: Now who were some of your peers growing up? You mentioned Pearlstein and Lois Dodd and we talked about Paul Klee yesterday, and Seurat. Who else do you find that youre pulling influences from when you made your art?

SHD: Umm. I lived on Tenth street.

HS: Oh you lived on Tenth street?

SHD: Yeah, I was on .....

HS: Do you remember other celebrities, artist celebrities at that time?

SHD: Artist celebrities?

HS: Yeah, or do you think that being in that gallery - did you influence other people's work? Other artists work in the gallery? Did they influence yours?

SHD: I don't think so.

HS: So everybody was just kind of working independently, displaying together?

SHD: Yeah. That's my feeling. 
HS: And you thought that it was a supportive environment? It wasn't a problem that you were a woman?

SHD: No. No. Not at all.

HS: Now how important-when you look back on your art making, is that the fundamental experience, working on Tenth Street?

SHD: That was a big one.

HS: That was a big one. What are some of the others?

SHD: Do you mean being influenced?

HS: Just exciting times when you look back and that was an enjoyable time to be an artist.

SHD: Well it was. It was, yeah.

HS: In your thesis that you wrote in Louisville in 1952--- let's start back, how did you get to Louisville? Why Louisville for a grad school?

SHD: What?

HS: Why did you go to Louisville for graduate school? The University of Louisville in Kentucky.

SHD: Yeah.

HS: Why did you go there for grad school from New York?

SHD: My parents where living there.

HS: Oh they were living there at that time?

SHD: Yeah.

HS: Had they just moved?

SHD: They moved there around 1951 I would say. I'm probably wrong about the date.

HS: But its close around, close around. And you would have started school pretty shortly after they moved.

SHD: I think so. Yes. 
HS: Did you like the program? What was the program like at the time?

SHD: Well, let me see. I was getting a Masters in painting.

HS: Mmm Hmm.

SHD: And I took the required work for a masters and I went there because my parents were there.

HS: Did you like the program or was it just a matter of necessity of what was near?

SHD: It was more of necessity.

HS: Why did you pick painting? Because you talk about in your thesis how you were conflicted that you wanted to study multiple disciplines but that they made you pick just one and stick with it.

SHD: Oh, well they did. That was it. There was no choice.

HS: No choice, so no mixing.

SHD: No, I don't think so.

HS: Was it the same at the gallery or could you experiment when you were at Tenth Street?

SHD: I guess I could experiment.

HS: Did you?

SHD: No.

HS: No?

SHD: No.

\section{Laughter}

HS: Why not?

SHD: I'm not an experimenter.

HS: That's interesting. Typically, we think of artists as always changing but I think that's one of the things that I find so interesting is that your work is very much consistent. 
SHD: Yeah. Well. Let me see...

HS: Now how did you go from making figurative works that you talk about in your thesis - of painting pictures of people or flowers - and then you started making the really abstract work, the abstract expressionism? What motivated that change?

SHD: It was the physical being there.

HS: In being there? In Louisville?

SHD: I'm thinking in terms of influences. I'm trying to be honest.

HS: Absolutely.

SHD: I'm not very clear.

HS: No, you're doing fine.

SHD: Umm. Now you asked me 'how did I go from figurative from abstract.'

HS: You said that you're not an experimenter, you don't like to change much. But you've had a couple major changes in your career. For one, in the very beginning, you were painting figurative items.

SHD: Yeah.

HS: Items that looked exactly like what it was supposed to, that you could tell what it was. And then you started working in more abstract, cerebral items. So what do you think motivated that change? Why change over?

SHD: Uhh. Well I think it was seeing work that I thought was good. I always wanted to be good.

HS: Always wanted to be good. For who?

SHD: Myself

HS: Yourself. When's the first time that you painted something and you said 'that's good.'

SHD: Oh. Well, I was living in New York and I had gone to college. When I was graduated and ...

HS: Do you need help? 
SHD: No.

HS: So you're in New York and is this around the time you're in the Tenth Street Galleries or is this before?

SHD: Before.

HS: Okay, before Tenth Street.

SHD: Let me see. I'd gone to college and I was doing. I'd gone to college and, ummm.

HS: Did you think that you were good before you started college?

SHD: No.

HS: What about at $\mathrm{U}$ of $\mathrm{L}$ with your masters, did you consider your work good then?

SHD: Hmm. I'm always seeking, I've always sought to be good.

HS: You've always sought to be good?

SHD: Yeah. Always. Of course, I wanted to be good and I liked good painting. But that was about all I could say on that subject.

HS: Yeah, absolutely. You always tried to be good.

SHD: Yeah.

HS: You were good once you got to New York you said?

SHD: In New York there was such an atmosphere. Friends and the atmosphere in New York was so different. It was sympathetic.

HS: Well here, I think they're [nurses]. Do you need a kleenex?

SHD: You met?

HS: Yeah, we got to meet yesterday.

Nurses care for Sally

HS: You said that the atmosphere in New York was just different. Different than Louisville or different from where? 
SHD: Oh, let's see, did I know anybody in New York? Well. I had a friend named Yonkers, a painter. Joslyn Booth and just being in New York was stimulating.

HS: Yeah.

SHD: I went to the shows.

HS: In Louisville, was it just - what was different? Is Louisville not stimulating? Was it that there wasn't as much shows or people or was it just a more conservative environment.

SHD: You mean being in New York?

HS: In Louisville, In Kentucky.

SHD: Oh. So what's your question?

HS: So how was Kentucky different than New York? Because that was a big move for you.

SHD: Yeah. Well let me see. I wanted to come to New York because that's where the action was.

HS: Yeah.

SHD: And, Uh...

HS: Did people like your art in Louisville?

SHD: Not particularly.

HS: Why do you think not?

SHD: Well I didn't know many people in Louisville and I didn't know hardly any artists, I might have known one or two. But I didn't know... It was not an art environment.

HS: So do you think that for your art to be liked by the people, do you have to know people or can the art itself be good and people like that?

SHD: What are you talking about being successful?

HS: Yeah. So you said that you didn't feel that they liked your art as much in Kentucky.

SHD: NO. 
HS: Is that because, do you feel that you didn't know enough people to write about it or where they just not ready for abstraction?

SHD: Um, well I think .... Your first.... Will you read it to me?

HS: Why didn't they like your art in Kentucky?

SHD: It was strange.

HS: It was strange?

SHD: Uh huh.

HS: Okay. Is your art still strange?

SHD: Well, its how to say. Its hard to say. Its not as strange as it was. My work going from Louisville to ......

HS: To New York?

SHD: No.

HS: Do you think that it was in Kentucky they weren't used to abstraction?

SHD: Yeah. A lot of it was that. And Louisville is quite conservative.

HS: It is quite a conservative town.

SHD: It is. Its such a conservative atmosphere - as differentiating that and Louisville.

HS: Okay. Now, talking about abstract art you have a line in your thesis I want to ask you about. In your thesis that you wrote in Louisville in 1952, you talk about abstract art that its not in the realm of human experience.

SHD: Ha!

HS: Is that something you still agree with?

SHD: Its not in the realm of human experience... Well that sentence is true.

HS: It is true? Okay. How so?

SHD: Not in the realm of human experience. I think its true, but I don't think it pertains really. 
HS: Okay. So its true, but not relevant.

SHD: Not relevant.

HS: Okay.

SHD: Yeah.

HS: Okay. Next question, in the thesis you also talk about the general confusion in artyou talk about how confusing the art world is and how everybody is just making art. Is the art world still confusing?

SHD: No, because I think, umm... I think... Now what was the first question, what was the question?

HS: So you talk in your thesis about how the art world is confusing. Do you think that it's still confusing?

SHD: Do I think its still confusing?

HS: Yeah, you say that there's a general confusion in art.

SHD: Well, in the big picture, it is confusing and has been confusing but not if you're focused on the, on something that makes sense.

HS: Is that why, maybe, that your work stayed so constant? Was it in response to the general confusion?

SHD: No, I don’t think so.

HS: How come it stayed so constant?

SHD: You mean my painting is constant?

HS: Yeah, so like, for example, a lot of people experiment all over the board, with subject matter or style or even with material but you stay with painting and you stay painting kind of the same, these meditative, starburst images for a long long time. And that's pretty rare.

SHD: You would say it stayed the same.

HS: A lot of people, when they look at your paintings, they say that they're calming.

SHD: They're coming? 
HS: They're calming. They're relaxing.

SHD: Yeah. Well they are that. That's a quality that I rather like.

HS: That's a quality that you like?

SHD: Yeah.

HS: Okay. So now, we're going to have a show in Louisville again, back in Kentucky and you haven't had one there since 1990 - so what do you want the show to demonstrate to the city and to the state that it didn't understand before?

SHD: Nothing. I mean uh, that's up to them.

HS: Do you think reactions will be different?

SHD: Well they might be. They've lived different lives and umm, I've lived different lives.

HS: What do you think is your audience-what do you expect from your audience when they go and they look at one of your paintings, what do you expect from them?

SHD: I don't expect anything from them but I'm thrilled when they like it.

HS: You're thrilled when they like it. Why is that?

SHD: Oh, I think you always want to be liked.

\section{Laughter}

HS: You once described your artwork as silent painting, so what does that mean?

SHD: Well, I wrote that a long time ago.

HS: It was a long time ago. Does it still apply?

SHD: Um, I don't expect it. I don't worry about it anymore.

HS: So at that time, what was the role of silence?

SHD: Well, a quiet quality.

HS: Is that what you wanted to achieve in your work? To create an atmosphere of quietness? 
SHD: Partially, yeah.

HS: Okay. So people, other critics, have described your artwork as being both energetic and meditative.

SHD: Ha!

HS:I thought that was an interesting contradiction. Can you work be both?

SHD: Angelic?

HS: Energetic, like, lively.

SHD: How do they describe it?

HS: They describe it as being energetic and meditative.

SHD: Oh.

HS: My question is how can it be both.

SHD: Well.

HS: One, do you agree and two, how does that work?

SHD: Gelling and what?

HS: Energetic, like hyper, really active. And the other one is meditative or calming.

SHD: They're both?

HS: Yeah, they say it's both. How do you feel when you look at, or when you painted it? Were you energetic or where you feeling calm? Or does it change?

SHD: No. I do think its quiet.

HS: You do think its quiet.

SHD: Mmm hmm.

HS: Well maybe they had just had too much caffeine. They were hyper.

SHD: Maybe. Maybe.

HS: Is your art personal? When you paint is it about you? 
SHD: No.

HS: Do you put yourself in it?

SHD: Well its I that painted it—that says its mine. It's about me but umm...

HS: Is the bird back? Oh, he's on your statue. Do you have a name for the bird?

SHD: No. Now let me see. Well, go ahead.

HS: Alright. We were talking about if your art is personal.

SHD: Oh.

HS: You said that its personal because you make it and that says something about you.

SHD: Maybe. Mhh hmm.

HS: Is it personal in any other way? Do you feel like you're telling a little bit about your personality or the history of your life or how you're feeling in your painting?

SHD: The last two.

HS: Or is your painting and your life completely separate. The last two works?

SHD: More than the last two.

HS: What were they last two questions? We were talking about if your art is personal.

SHD: Yes, its personal.

HS: It is personal.

SHD: Sure.

HS: How so?

SHD: Well, Its personal in the sense that I made it.

HS: Its personal since you made it. Can people, when they look at it, can they tell anything about you?

SHD: No. Well, I guess they could. But not very interesting. 


\section{Laughter}

HS: I don't believe that. So, sometimes you give your works titles and sometimes you leave them untitled.

SHD: I know it. Sometimes they're wacky titles. That one that's on the cover. Laughs.

CD: Hi mom. We're back finally.

SHD: Well, you must've bought out the store.

HS: She wants to know what you bought at the store.

JC: I bought you a hamburger. Laughs. No, we're going to cook a steak out tonight.

SHD: Oh, that's good.

HS: So you said sometimes the titles are wacky. Are you ready to take a break?

SHD: No, not yet.

HS: Okay. Alright. You just let me know.

SHD: Umm. Sometimes there's... the titles are good and some titles are bad.

HS: Okay. What's a good title?

SHD: Umm, Let's see. Sometimes I think that there is a good title and sometimes I think there's a lousy title. And sometimes there doesn't have a ...

HS: So when you don't have a title you leave it untitled?

SHD: Mmm Hmm. Yeah.

HS: So what makes a work have a good title versus...

SHD: It just happens. Incomprehensible.

HS: Something left its mark and that's the title? What left its mark?

SHD: Sometimes its... sometimes, well it doesn't sound like a good title.

HS: Sometimes it doesn't sound like a good title. So we've heard a lot of other people, art critics, talk about your work, or gallerists talk about your work, what would you say about your work? How would you describe it yourself? 
SHD: Well, I'd say its contemplative.

HS: Contemplative.

SHD: Describes it pretty well. Umm.

HS: What do you expect people to contemplate when they look at it?

SHD: You were all seaman. You were all seaman. (unsure about this see-man?) It has to mean something to them.

HS: What it means to them.

SHD: Mmm Hmm.

HS: Now sometimes with the paintings, the center is dark and sometimes it has a light center.

SHD: Yeah, it's about separation because... actually, Lois Dodd suggests I make them light in the center.

HS: She told you to make them light in the center?

SHD: Yeah. I did. And, umm, I liked what I saw. They're light around the edges and I like that. They seem to have a certain spirit.

HS: Is that spirit different than when the spirit is dark?

SHD: Yeah, because then light in the center, there's a certain exuberance that they didn't before.

HS: Hmm. Can you talk about your process of how you make them? And I know that's changed over time. So if you have a blank canvas, how do you start making?

SHD: How do I start?

HS: Mmmm Hmm.

SHD: Well I cover, usually I cover with a base color all over and one painting leads to another painting.

HS: One companion?

CD: No. 
SHD: One painting.

CD: One painting.

HS: Painting. Okay.

SHD: Leads....

HS: Leads to another painting.

\section{Laughter}

HS: So how would you pick the colors you would use? So you start with one color and then you start adding colors on top?

SHD: Yeah.

HS: How would you pick which color. Is it whatever you're feeling that day?

SHD: Yeah. The painting that went before.

HS: The painting that was before?

SHD: Usually dictates what comes afterwards.

HS: Oh, it dictates what comes afterwards. So you put the dots on-how do you apply the dots?

SHD: With a little brush. Laughs

HS: With a little brush. So you do use the hair side not the end-side?

SHD: The what?

HS: So you're just dipping it in and adding a little dot with the side that has the hair as opposed to flipping the brush around?

CD: Oh, some people use the other end sometimes? I didn't know that. Did you know that sometimes, apparently some painters, they'll use the actual stick end to apply the paint.

HS: Yep.

CD: But mom used the brush side. 
HS: The brush side.

SHD: Mmm Hmm.

HS: Now how, your dots - it seems that they get smaller. Like in the earlier paintings, the dots are bigger and then in the later paintings they're smaller and farther apart.

SHD: Well I think that's because I wanted an intensity.

HS: You wanted an intensity. With the smaller dots?

SHD Nods

CD: They seem to give you more intensity with the smaller dots. I can see that.

SHD: Yeah.

CD: Right mom? You felt they gave you better intensity than the larger strokes.

SHD: Yeah.

HS: Perfect, Okay.

CD: Mom, want a sip? Ice tea. Here's some ice tea. I'll hold it.

HS: Are you ready for a break?

SHD: Yeah.

HS: Okay, lets take a break.

\section{Session 2}

Conversation with Sally Hazelet Drummond, John Clark, Craig Drummond and Hillary Sullivan

HS: Every place has a history.

CD: Every place has a history.

SHD: Everybody, every person, every family has a history.

Discussion about schedule for day, questions about myself 
SHD: What about my work? Why did you pick me?

HS: Why did I pick you? So the story is, I'm sitting with John Begley from LVAA, who did your show in 1990 and we are going through the online database of everything that $U$ of L owns artwork-wise and it's pretty extensive. And each of it has pictures and we're going through and I'm like 'I don't like it' 'I don't like it' 'I don't like it' and yours came up and I said 'that's interesting.' And so he said 'well she was the first female graduate from the Hite Art department' and I said that's it.

CD: I just learned that this last week, I didn't know that.

SHD: He said what?

HS: He said you were the first woman to graduate and so I said 'that's it.' 'that's done.'

CD: That did it for you.

HS: Yeah.

CD: Interesting. Huh.

Discussion about CCS program from U of L, museology

SHD: I just don't understand why you would pick me.

HS: I gotta tell you, you're interesting

\section{Laughter}

CD: There you go. Well, she liked your artwork when she saw it.

HS: yeah, the work is beautiful.

CD: and you're the first woman to graduate.

SHD: Oh yeah.

HS: First woman to graduate. And that's a big deal.

SHD: incomprehensible Oh that's right.

CD: Pretty good, sensible reasons. 
HS: Yeah, and it was interesting to me that you worked in Louisville and your so successful-you have work in the MET, you had a uh, a retrospective in the Corcoran, these are really big deals, but in Louisville I had never heard your name before that moment.

CD: Mmmm Hmmm.

SHD: Incomprehensible, Laughs

HS: And that should never happen

CD: Ahhh, Good.

HS: That was interesting is how come we have someone who is so successful everywhere but Louisville.

CD: Right.

HS: And that was really odd. One of the things I hope is that at the end of the show, people will know your name.

SHD: Laughs

CD: That's nice. Isn't that nice mom?

SHD: That they'll know your name.

HS and CD: That they'll know your name.

CD: Your name will be more well known in Louisville than its.... If it's known in New York City, then it should be known in Louisville.

HS: So the same thing that happened to me doesn't happen again. Yeah.

CD: She felt like you're under-represented or you know, you're like a jewel that people don't know about in Louisville.

SHD: Laughs

CD: And that's where you went to school and lived so...

SHD: Yeah. Right.

CD: Is that kind of what you're saying?

HS: Absolutely. Absolutely. 
JC: I would say that maybe they have forgotten about you.

CD: Maybe

HS: So we're going to remind them.

SHD: Oh.

CD: Good, that's great.

JC: And now you're found again.

CD: Rising from the ashes, a phoenix.

\section{Laughter}

CD: It looks like she might be. It looks very encouraging that she might be selling two paintings over in Switzerland.

HS: Oh, from the show that's up there now. Great! That's good.

CD: Yeah. Yeah. However its not, its not in ink yet but it looks very encouraging right now.

HS: Good.

CD: Its exciting.

HS: There you go, you'll be internationally collected.

SHD: Yes.

\section{Laughter}

HS: That was a pretty show. I saw stills from it.

CD: Oh you did? I haven't. We should probably be able to access it somehow from through, uhh...

HS: Yeah, and I'll make sure that, because I'm in the process of collecting everything that's ever been written about you, so that will be passed on when I'm done to the gallery and to you all so that there's a permanent record. 
CD: Yeah. I'm going to dig. I know that mom has a file here somewhere full of press stuff.

HS: Oh. Fabulous.

SHD: Mmm Hmm.

CD: So today I'll be trying to locate that. I shouldn't be too difficult.

SHD: Yeah, I have saved stuff.

$\mathrm{CD}$ : Saved a bunch of clippings right?

SHD: Mmm Hmm.

JC: I don't know. Are you going to get into the Tenth Street Group?

HS: Yeah, absolutely. I mean, not as much as, that's a whole different story...

JC: Right.

HS: But yeah, I don't think you can talk about Sally without talking about the Tenth Street Gallery.

JC: Yeah.

HS: It'd be very hard to divorce it.

CD: Good, Good.

JC: And the folks that she was hanging around with.

HS: Right. Yeah.

SHD: Mmmm Hmmm.

JC: In that area. I don' $t$ know, you can figure that out.

CD: You ready to do a little more Mom?

SHD: Yeah.

HS: You've got to let me know when I make you tired. So we were talking initially about the process of how you start your painting. So I'll pull out a couple of pictures if you just want to talk about how that was made. 
SHD: Mmmm Hmmm.

HS: Does that make sense?

SHD: Yeah. You asked me how I got started.

HS: Yeah. So how did you make that?

$\mathrm{CD}$ : Can you remember the process?

SHD: Well, I put a little in the middle.

CD: A little dot in the middle I think. Is that right? Cause you figure, you must figure, I didn't think about it, but you must figure out the absolute center is. She uses....

SHD: Oh yeah.

HS: So you start in the middle then?

SHD: the middle. And work out.

HS: To the edge? Now how do you pick what color each of the dots is going to be?

SHD: Oh. One color leads to another.

HS: One color leads to another.

CD: I think that's what she meant about, not the painting.

HS: Yeah yeah yeah.

CD: Not the paintings.

HS: Yeah. I got you. So is that the same process that you always had, that you always.... SHD: Yeah.

HS: Started in the center.

SHD: Well, pretty much.

HS: Pretty much, okay. I'm trying to think. Now how about did you start some of your older work and I've got a picture of that (woman sitting, abstract). 
SHD: This is great what you're doing. I'm really happy about it. Oh yeah, that's good.

HS: So how would you start, like, these two.

CD: You remember those Mom?

SHD: Yeah.

CD: We have those...

HS: You have ones like it, I think ...

CD: Ones similar to it.

SHD: And upstairs too, I have one.

CD: Mmmmm Hmmm.

HS: I think you have two.

CD: I don't remember seeing that one around here. Can you... Do you remember how you would have started those? Because those are very different.

SHD: Yes yes.

CD: You'd start with kind of a random stroke?

SHD: Yeah. Yeah. Mmmm Hmmm.

HS: and then you'd add the white on afterwards?

SHD: This is a figure.

HS: Okay. Let me get a pen.

CD: Here mom, have a sip.

HS: Where would you start on one like this?

SHD: Like that?

CD: Mmmm Hmmm.

SHD: With the figure... 
CD: Would you do kind of a rough outline of the figure?

SHD: Mmmm Hmmm.

CD: Is that what you would do to get started on that?

SHD: I've forgotten what motivated.

CD: Motivated you?

SHD: Mmm Hmm.

HS: That's a pretty traditional image. Do you remember when did you start- I know that you said that Lois got you to start doing the lighter centers- do you remember when that was?

SHD: I was in my...

$\mathrm{CD}$ : Can you remember when you switched from the dark center to the light center?

SHD: No I don't really.

CD: Now I know that the paintings that she did in the 70s, I think its safe to say that they were all light in the center. The ones you did in the 70s?

HS: yeah. I'll be able to backdate that.

CD: Yeah. And probably even somewhat before that.

SHD: Yeah.

CD: I think in the 50s you were probably_-I'm being very gentle-but I think in the 50s is when you're doing the dark center.

SHD: Probably, yeah.

HS: Now would say that your art is spiritual?

SHD: Is spiritual?

HS: Mmm Hmm. People have said that about your art but I want to know what you think. SHD: Well I don't see it as spiritual. It may have a spiritual quality to it. 
JC: That's specific. That's interesting that its not spiritual but it has a spiritual quality to it?

HS: Yes.

SHD: Yeah.

CD: Interesting distinction. Yeah.

SHD: It doesn't seem to make sense but I think that it has a spiritual quality to it.

CD: That's, uh, okay. Its not a spiritual painting.

SHD: No.

CD: But its, there's a spiritual side to it. Kind of.

HS: Now when did you start studying Buddhism?

SHD: Oh. What about it?

HS: When did you start studying Buddhism?

SHD: Um. Well. Um.

CD: I think it was in the 80s. Right? I know it was in the 80 s.

SHD: Okay.

CD: It was in probably the early to mid 80 s.

HS: Early to mid 80 s.

CD: Yeah, Because she started um, she got over-what I remember of the beginning of the process was that she started doing some tai chi classes. Taking Tai Chi classes.

SHD: Mmm Hmm.

$\mathrm{CD}$ : And I think it was from there and that was probably the late 70s. And that's how she got over to Buddhism. I don't know the specific connection. Does that sound accurate?

SHD: Yeah, that's probably accurate.

HS: Do you think Buddhism changed your art?

SHD: No. 
HS: No. Not at all?

SHD: I don't think it did.

CD: That's a good question.

HS: Yeah, some people say it so that's good, I'm glad.

CD: I'm going to go get something. Ill just go right out and be right back.

JC: What did Buddhism do for you?

SHD: It was a faith. Like Catholicism.

HS: It was a belief?

SHD: Belief.

CD: Faith?

SHD: To me umm... To me I don't go to the monastery... ummm... so hard to talk about this stuff. I don't t go to the monastery. A., I appreciate it, I like it

HS: Yeah. That's a good reason to do something.

SHD: Mmmm Hmmm. Yeah. Umm. And I don't go there. Look at this crazy bird.

HS: This bird keeps coming back.

JC: Why do you go to the monastery? What is it that... What do you....

HS: She said she doesn't.

JC: Oh, she doesn't go to the monastery.

SHD: Uh huh.

JC: But you did for a while.

SHD: I would still go if I were...

JC: Able.

SHD: Able and uhh.... 
JC: Had a car.

SHD: I had a car.

JC: And why did you go to the monastery? Why did you ... what was your... You say that Buddhism didn't affect your art but uhh....

SHD: No. I can't say it has. But I've... I like it as a practice.

HS: So it affects your life.

SHD: Hmm?

HS: It affects your life, everything else.

SHD: Yeah. And then when I went, I liked the people too.

JC: The people?

SHD: Yeah. They're nice.

JC: The friendships.

SHD: Hmm Mmm.

HS: So we talked yesterday, but I didn't get it on camera. This is one of your first paintings, Heart of Iron, from 1960.

SHD: Oh Yeah.

HS: Yeah, yeah. When did you first start painting these with the centers, the starburstslike paintings?

SHD: The centers?

HS: Yeah Yeah, so like all of your paintings have the center that is either dark or light.

SHD: Mmmm Hmm.

HS: And then it expands outward. Do you remember when you first started doing those?

SHD: No I don't.

HS: You said you went to the exhibit in 1954, the Seurat exhibit. 
SHD: The which?

HS: The Seurat, the Georges Seurat, yes. Is that the first time you started using dots?

SHD: Mmmm Hmmm. Dots.

HS: Did you use dots like this (gestures to paintings) or did you use dots to make like figures?

SHD: Oh no. I was doing this. I like to do it then.

HS: Perfect. So you went to that show in 1954 and you said that you would just stop and stare in front of the paintings. What was it about dots that were different?

SHD: Well, Seurat's had an energy to them and I was doing a ... so called...

HS: Do your dots have an energy?

SHD: I think the use of dots does.

HS: The use of dots does.

SHD: Yeah.

HS: Okay. That goes back to what we talked about earlier because people have described your paintings as being both energetic and meditative. So if the dots themselves have an energy than the overall painting, does it have an energy but creates a meditative or contemplative tone.

SHD: I would hope so.

HS: You hope so.

SHD: Mmmm Hmmm.

HS: Perfect. Now in your thesis you have a paragraph Sally, and its really funny, you say that there's more art critics than are actual artists.

SHD: laughs

HS: And you say, you completely, you talk about how silly art criticism is. So what is the role of art critics today? Or what is the role of art criticism in general?

SHD: I don't think there is a big role. 
HS: There is or is not?

SHD: Is not.

HS: Is not a big role.

SHD: People are going to like your work or not like your work. It makes no difference in the matter of what style it is.

HS: There you go. Now we talked a little bit earlier about success. How do you define success?

SHD: Success?

HS: Hmm Mmmm. Success as an artist.

SHD: A successful artist is an artist who sells his work.

HS: Who sells his work.

SHD: That makes a success.

HS: That makes success.

SHD: Mmm Hmm.

HS: That's success.

SHD: I think, I think so.

HS: Would you say you're successful? I would say you're successful.

SHD: Well, compared to who? Compared to a lot of artists, I'm not successful. To some artists, a number, I am.

HS: Yeah? I think for me, and where I'm getting at is that you talk about that you made artwork for you. I said, 'when did you know it was good,?' you said you knew it was good when you liked it.

SHD: Laughed Uhh Huh.

HS: And so, so much of it is that you've done this for yourself more than you've made art for other people. 
SHD: Yeah.

HS: And the fact that you were able to stay true and to do what you want when everybody around you had an opinion.

SHD: Yeah.

HS: I think that's a mark of success.

SHD: laughs Okay.

HS: What are your thoughts?

SHD: Well, that's not how I would define success.

CD: You said 'that's not how I would.."

SHD: No, that's what I meant.

CD: Well, wouldn't you say Mom that if people liked. Lets say..."

SHD: If people like it, that's successful.

CD: Okay, Even if its art that you think is not very good?

SHD: Yeah

CD: You still call it successful?

SHD: No, successful is sold.

CD: If its sold.

HS: So the art market is what says its successful.

SHD: Yeah.

HS: Okay. Now what has been your relationship and role with the art market?

SHD: Laughs, surprised face.

\section{Laughs}

HS: That was quite the reaction! So when you were in the Tenth Street Galleries was there a lot of pressure to sell... 
SHD: No.

HS: or was the focus just on making?

SHD: Just having a show.

HS: Just having a show.

SHD: Mmm Hmm.

JC: Was that successful? If you had a show, was that a measure of success?

SHD: Umm...

CD: Just having a show, is that a measure of success by itself?

SHD: No.

CD: See Mom, I remember, I know that you have-You've had opinions about various art, like modern art, you know, newer artwork. I've heard you... I mean, there's art that you like and there's are that you don't like.

SHD: Mmm Hmm.

CD: You personally, out there.

SHD: Mmm Hmm.

CD: And, I'm pretty sure I remember you saying something along the lines of stuff that, just because it sells, I think, I think that you... It's my opinion that, I think you.... Just because it sells doesn't mean that its necessarily good art.

SHD: Nuh Mmm.

CD: Right. And, um, I guess there's a difference between art that's quote on quote 'good' and art that sells.

SHD: Mmm Hmm.

CD: Just because it sells, it doesn't mean that its quality art.

SHD: Uhnn Uhnn. 
HS: So would you say that you have, the fact that your art was able to stay what you wanted it to be, that you made what you wanted as opposed to what would have sold on the art market, what is that called? Is that integrity?

SHD: That means that you have a nice father.

HS: That means you have a nice father.

Laughs

SHD: Who supports you.

HS: Who supports you. So why, why continue to make that work? So if you weren't trying to be successful...

SHD: No.

HS: Okay. So what motivated you to paint the way and what you did?

SHD: A., I wanted to paint and B., It was that kind of work.

CD: Mmm Hmm.

SHD: And umm, people around you, like my parents and their friends, I uhh, they, well, that's enough.

HS: Okay, Last few questions before we head out. What was it like being a female artist.

SHD: Well you see, you ask that because.... I never thought about it until I got a letter from New York one time and there was a woman who, who was, umm. Had a reputation and she just talked about that.

HS: But it's not something you ever thought about?

SHD: No, I really didn't, but I got a letter from her and she's saying this. Oh I'd say this was about four years ago or five years ago. She talks about, umm, women painters and had a rough time of it and um, I couldn't... In my answer to her, I acknowledge that it was difficult being a woman and being a painter and so I said something about... but anyway, that's what I said. It's true, there is a prejudice against women.

CD: Prejudice.

HS: Okay.

SHD: And, uhh, that's about it. 
HS: So how did you over come the prejudices and the biases?

SHD: Well, I got, I was in painting before I.... A., I slowly and soon, I was interested in painting and the fact that I was a woman never occurred to me. Never did.

JC: So the painting was the expression. So there was, the painting stands for itself.

SHD: Yeah.

JC: The painting or whatever, regardless of whether it's a man or a woman.

SHD: Yeah.

JC: Is that what you're saying? It never occurred to you that you were a woman painting. You were a painter painting.

SHD: Mmmm Hmmm. That was it.

JC: You were an artist painting, not a woman painting.

SHD: No, sex...

JC: Had nothing to do with it.

SHD: Had nothing to do with it.

HS: Did you have problems because other people noticed your gender? Was it difficult for anybody else? Do you remember any biases?

SHD: Oh.

HS: That's your motivation but you're still in an environment that there was very few women at the time-especially in abstract expressionism.

SHD: Yeah. There were. Well, women artists, I never thought about that quality—being a female, painting didn't....

CD: It wasn't a prominent thing in your mind.

SHD: No.

CD: It was more of a painter. Whether there was sex, you didn't think much about it. Whether it was a male painting or a woman painting. Is that true to say? 
SHD: I think that's true.

CD: Its how you felt? Mmm Hmm.

JC: How did the male painter treat you?

SHD: Oh.

JC: How was that relationship? The male painter to the woman painter. You know, was there any ....

SHD: Ummm.

JC: The relationship or was there respect or were they...

SHD: They ignored me.

CD: Huh?

SHD: Often I was pretty much ignored.

$\mathrm{JC}$ : By male painters?

SHD: And female.

Laughs

CD: you felt that you were ignored to an extent. By both sexes.

SHD: Yeah. Pretty much.

HS: Did that bother you?

SHD: Well prejudice in any form bothers me.

CD: Mmm Hmm.

SHD: And uhh, the problem of, uh...

CD: Did you feel, uh, when you were in the prime of your painting career, did you ever experience, like specifically resistance, or you know...

SHD: Because I was a woman?

CD: Right. 
SHD: When?

CD: Some kind of obstacle I should say, it would be a better word.

SHD: Yes, I think it was there. But I never thought about it much.

CD: Okay. But you sensed it though.

SHD: Umm Yeah.

CD: Mmm Hmm.

SHD: I think so.

CD: I'm sure you did. Especially back then.

JC: Lois didn't ignore you.

SHD: No.

$\mathrm{JC}$ : Why is that I wonder?

SHD: Well she's a woman and she's uhh, I don’t know.

$\mathrm{JC}$ : What made you and Lois click?

SHD: Laughs Oh, umm, I think friendship and you know, we liked the same things.

CD: Lois has been a wonderful friend. Especially since, she [Sally] had a stroke in 2010, a mild stroke, and Lois has been great about calling. She's been good. I mean, she's been a longtime great friend but she's really continues to be even though, you know, you're not as capable as you were.

HS: Good. Okay. Okay, well I think we're at about our time limit, its almost 12:30.

JC: Are we?

SHD: Mmm Hmm.

CD: How are we doing.... How is the game plan?...

HS: I'm seeing it in the book right now. 


\section{$\underline{\text { Session } 3}$}

SHD: Well, I don't have any real questions I think.

JC: When did you meet Wick?

SHD: What?

JC: When did you meet Wick?

SHD: Wick and I, uhh, his and my family both were interested in houses. And, umm, the subject came up and we said that he was interested in houses. So was I. And umm, so that got us started.

HS: Where did you meet him?

SHD: Through our house. We were living in the country. In your [JC's] house. And uh..

$\mathrm{JC}$ : in O'Bannon?

SHD: Umm, yeah.

$\mathrm{JC}:$ The farm?

SHD: Yeah.

JC: The little farm?

SHD: Mmm Hmm.

JC: You know, just outside of PeeWee Valley. Outside of PeeWee Valley, in....

SHD: Yeah.

JC: In between PeeWee Valley and ...

HS: O Bannon state park?

JC: No, uhh, O Bannon is uh, no longer there. It's a city that's gone.

HS: Oh.

CD: Really? 
JC: It's a town that uh, is in between PeeWee Valley and Anchorage on LaGrange Road. Right?

SHD: Right.

JC: And that, How.. How did.. There's a story about that. That's how mother and dad got the farm isn't it?

SHD: Yeah?

JC: Was Wick, how did Wick?...

SHD: Well he lived in that house at that time. On the Farm.

JC: Oh, he did. In the Drummond house?

SHD: Yeah.

JC: I'll be dangit. I didn't know that I guess. Did mother and dad buy the farm from the Drummonds?

SHD: Ummm

JC: No, Wick just happened to be living in, on the property?

SHD: Yeah. And umm, his family lived in the farm.

JC: Right.

SHD: So when we bought the farm...

JC: And so that's how you met him.

SHD: And I think that's how I met him.

JC: How old were you then?

SHD: incomprehensible.

JC: Well that's interesting.

HS: What did he think of your art? Did he like the fact that you were a painter?

SHD: He didn't talk about it. 
HS: He didn't talk about it. In the beginning or he didn't talk about it ever?

SHD: In the beginning. Mmm. Later he talked about it.

HS: What'd he have to say about it?

SHD: Well he didn't have a lot to say about it but uhh...

CD: Just setting up for dinner later, thought we'd eat outside.

SHD: Okay. Good.

JC: Oh wow.

CD: That sound good?

SHD: Yeah.

JC: It'll be cooler tonight. I think, it'll be alright.

CD: Yeah. Its not that bad out now anyway.

HS: So did you all have a lot of your paintings hanging up?

SHD: A couple. And umm...

HS: And when did you have Craig?

SHD: Well we were married about uhh, let me see.. Craig?

JC: When were you born?

CD: 62. 1962.

JC: And when, when were your mom and dad married?

CD: 61. In Louisville.

SHD: Mmm Hmm.

CD: At, uh, ....

SHD: How did we meet? 
CD: Yeah, that's something. It had to do with houses. Umm. I think, I know that, I believe that Johnny's, or I should say mom's sister Sue and brother-in-law John, I believe they purchased a property, a house, from Wick.

SHD: Yeah.

CD: Mom's husband. I mean, from his family I should say. And ...

JC: That was in O Bannon, that little farm, like 20 acres.

CD: Right. Right. And I think that's generally the context in which, and I can't get any more specific than that. I think that's how they...

HS: So you were in Louisville at that time and where all else did you live besides Louisville and New York?

SHD: Yeah.

CD: Boy you are from that area aren't you?

Laughs

HS: Is it the way I say it?

CD: Lool-vull.

HS: Yep, gives it away.

CD: Yep.

SHD: I was born in uh...

CD: Evanston.

SHD: Evanston, Illinois.

HS: Mmm Hmm.

CD: Outside Chicago. Isn't that not too far from Chicago?

SHD: Mmm Hmm. Yep.

JC: Libertyville.

SHD: Libertyville. And uh, that's how that happened. 
CD: She grew up in, she's born in Evanston. I don't know how long. How long did you live in Evanston, Mom, after being born? Not very long I don't think.

SHD: Not very long, no.

CD: I think she did her primary growing up in Winnetka.

HS: Which is?

CD: Outside Chicago also. Kind of a suburb. North Shore. North of Chicago. And then, later on... were you still in high school? I guess you were. Were you living at home when you moved to Libertyville?

SHD: Mmm Hmm.

CD: Which is a little bit further out in the country.

SHD: Mother always wanted to live out in the country.

CD: Her mother always liked the idea of living in the country. And you were still living at home I believe, right? When they moved to Libertyville?

SHD: I think so, yeah.

CD: And then she, umm, went off to college. Now did you get into her...

HS: No, we haven't talked about college yet.

CD: You want to take a crack at that Mom? Tell Hillary about your education, your uh..

SHD: Well uhh...

CD: Post-High School. So she went to a umm, a very good high school at the time, maybe still was of some national repute. Call New Trier High School. There's a township that had served a bunch of towns, but it's a beautiful old high school. Very large and they had great sports programs, you know, great teaching...

JC: Marlon Brando went there. [Not true]

CD: Oh that's right. Not only did Marlon Brando go there, mom went on a double date with Marlon Brando.

HS: I worked for another artist who dated Marlon Brando. 
JC: Really?

SHD: Who was that?

HS: Anita Steckel.

CD: Huh.

HS: She worked out of New York too.

$\mathrm{JC}$ : Interesting.

SHD: Anita...

HS: Steckel. She dated him as well.

CD: Wow, that's funny.

SHD: Yeah.

CD: Now mom was not actually, to be fully accurate, Marlon was not her date.

HS: She was on the double date with him.

CD: Correct. Right.

SHD: I don't remember that.

JC: Well Craig does.

SHD: He wasn't there. I was.

CD: I remember it from what you were telling me.

JC: Pretty good.

Laughs

CD: That's how good my memory is.

HS: Yeah, we can tell.

SHD: Anyway. 
HS: We were talking about college. And your schooling. So you went to the high school, and then where from there?

SHD: Uh, Rollins. And I was...

CD: Have you heard of Rollins?

HS: Hmm Mmm, we talked about it at lunch actually.

CD: Oh, oh, okay.

SHD: Umm...

JC: Gretchen went to Rollins.

CD: Oh she did?

JC: My wife.

CD: I didn't know that.

SHD: Oh yeah. She went to Rollins too.

CD: I didn't know that. Cool.

SHD: She's a Theta.

CD: Oh really? Kappa Alpha Theta?

JC: I don't know if she was a Theta, she was a ....

CD: She was a Greek?

JC: She was a Greek.

CD: Kappa Kappa Gamma? Mom was a Kappa Kappa Gamma.

HS: Oh, so you were in the sorority.

CD: Yeah.

JC: I can't remember what her, uh... But that doesn't ring a bell.

CD: Oh, okay. 
JC: Could be.

HS: Did you take art classes at that time or was it general studies?

SHD: Yeah, there was one teacher that I liked very much. Her name was... Umm...

CD: It was a good teacher that you liked very much?

SHD: Yeah.

CD: Art teacher I guess?

SHD: Art teacher. She taught sculpture.

HS: She taught sculpture.

CD: Are you talking about, umm, Ulfert Wilke?

SHD: No.

HS: That's a man.

JC: Ulfert was at the University of Louisville.

SHD: Yeah.

CD: Oh, alright. So , umm, anyway.

JC: But that's a good name.

CD: Yeah. Johnny was saying that Ulfert Wilke was a meaningful name.

SHD: I have one of their paintings. Hanging.

HS: Oh you have one of her paintings?

CD: No. They have one of your paintings?

SHD: Yeah.

JC: No. Who does?

CD: Who does?

SHD: Mr. and Mrs. Wilke. 
CD: Oh. Mr. and Mrs. Wilke.

SHD: A pink painting. Its over, is uhh.... Are you hot?

CD: No.

SHD: Ummm, Umm.

CD: The Wilke's have a painting.

SHD: Right.

CD: Right. And its one of your paintings I guess?

SHD: Yes.

CD: Got it. That's cool.

SHD: No. Its one of the....

CD: Oh, one of their paintings is hanging somewhere. I'm trying to figure it out. Who did the painting that you're talking about? Ulfert?

SHD: Mmm Hmm. Ulfert.

CD: Okay, one of his paintings?

SHD: Yes.

CD: Okay, one of his paintings. A very nice painting. Yes, okay.

SHD: Do you know the one I'm talking about?

JC: I might. Which one does it look like? Is it big or is it little?

SHD: Its big. It was big-ish.

CD: Good size? Three feet?

SHD: Mmm Hmm.

JC: Is it little, very little lines? Or is it more abstract? You know, more uh, big shapes.

SHD: Its, uh... 
JC: Do you remember?

SHD: It's a pinkish painting.

JC: Pinkish.

SHD: and it was hanging over ....

CD: Over a mantle or over a couch or something?

JC: Ah, over Sue's house?

SHD: Yeah.

JC. Yeah. Over her sideboard?

SHD: Yeah.

JC: That's the one I pointed out to you. It's, uh, remember that before you go down to the basement. Its hanging in our house now. But in another area.

HS: Yes, I remember.

JC: And I also have another one. Of a, a little bit smaller one.

SHD: Of Ulfert's?

JC: Of Ulfert's. That was, it was very little, like uh, hash-tags. They're very small, but lines.

CD: Thinner lines?

JC: And I'll put, uh, matchsticks put uh.. I meant to show it to you, we walked by it or whatever.

HS: Mmm Hmm.

JC: It's hard to see because its in that little hallway in the back with the glass. But, uh, it is, uh, frankly my favorite ones of his. That I mean...

SHD: What?

JC: I like his painting. 
SHD: It was a nice painting.

JC: And I forget where that one came from because, uh, it may have been in grandmother's house.

SHD: It was.

JC: But both of them probably.

SHD: Yeah.

HS: So what was he like as a teacher? Ulfert.

SHD: Well you see, I liked him. I liked him. So I liked about his teaching.

HS: You liked him so you liked his teaching?

SHD: Yes. I liked his teaching because I liked him.

JC: Because you liked him, you liked him, so you liked his teaching.

SHD: Yeah, well both.

CD: You probably liked him both individually.

JC: Yeah.

CD: You liked him as a person but you also did like his teaching style — is that fair?

SHD: Yeah.

JC: Did he let you do what you wanted to do?

SHD: Umm, pretty much.

JC: Do you remember his personality?

SHD: Well, he was German. German.

CD: German.

JC: German, yeah.

SHD: And he umm, talked really fast as I remember. 
CD: Talked rather fast.

SHD: He was a very Incomprehensible artist.

CD: artist.

SHD: Yeah.

CD: He was a very what artist? You used a word.

SHD: Umm, he was very much an artist.

CD: Very much an artist.

SHD: Mmm Hmm.

CD: He's like an artist's artist.

SHD: Yeah.

CD: He was a really, he was a legitimate...

SHD: He was a good painter.

CD: A very committed artist.

SHD: Oh very much so.

JC: Did he have a high energy level?

SHD: Yeah.

Laughs

SHD: Who....

CD: Did you ever meet him?

JC: No I never did meet him but I've heard people describe him.

CD: Oh what, what...

SHD: High energy.

JC: That he had a high energy level and that he.... 
SHD: Yeah.

$\mathrm{JC}$ : kind of jumped around from thing to thing.

SHD: Yeah. And he did. Mmm Hmm.

JC: And it was hard to keep up in the conversation into with him. He was so enthusiastic.

$\mathrm{CD}: \mathrm{Mmm}$.

SHD: He was very enthusiastic.

CD: Oh he was? And that often makes for a good, can help to make for a good teacher.

JC: Yeah, I think so.

CD: You know, when somebody's....

SHD: I think so.

HS: Now can we talk about your dad for a little bit more? So while you were going to the University of Louisville, your parents, you were staying with your parents?

SHD: Umm, yeah.

HS: Yeah? And you said he supported the art. Is that from the get-go? From the very beginning?

SHD: Daddy?

HS: Mmm Hmm.

SHD: Umm, he was interested in what I was interested in because of our relationship.

HS: Were you all close?

SHD: Did I work hard?

HS: Were you close with your dad?

SHD: Umm, yeah, but not terribly.

CD: But you had, you had a good relationship though. 
SHD: Yeah.

HS: What about your mom?

SHD: My mother was a wonderful uhh, was interested in painting.

HS: Oh she was?

SHD: Well, she didn't paint but she liked it. She was very much trying to go to the Speed when they had a show on.

HS: Did she like your painting?

SHD: Oh, I think so. She always said that she didn't know much about painting but she liked my work and she liked me.

Laughs

SHD: And that influences you.

HS: Yeah.

CD: As an artist?

SHD: Incomprehensible. And she was artistic.

CD: You said she was or was not?

SHD: Was.

CD: Oh. Your mom was?

\section{Cell phone}

JC: Excuse me.

CD: Oh, okay.

HS: What did she do that was artistic?

SHD: Well she, our house is not as it was. When she was here, she was artistic and uh, and that was reflected in her taste. You asked me about ... She was one of the, one of the, that liked interesting people.

HS: Your mother was one of the most interesting people? 
CD: She liked interesting people.

HS: She liked interesting people. Okay.

SHD: And uh, she liked people who had something to say, and uh, that was that.

CD: Did she ever do anything creative herself?

SHD: She took a class at pasterstoo (?) passpartoo (?)

CD: Passparoo?

SHD: Yeah.

CD: What's that? Is that a type of art?

SHD: Its uh... incomprehensible, yeah. It's a, it's a form. Paspartoo.

CD: Is it painting or is it uhh...

SHD: Its flat, yeah.

$\mathrm{CD}$ : And she took a class in it?

SHD: Yeah. Hmm. Once.

JC: I can't remember what that means.

CD: Is it a style of painting or is it like, like, pointillism or ...

SHD: Let me see.

CD: Is it something like pointillism? I'm just picking out something.

SHD: Yeah.

CD: To try to understand that term. A French term, sounds like. Is that a French term?

SHD: Yes, I think it probably is.

CD: Sounds that way, but...

HS: So what was your art making like after you had Craig? 
SHD: It was just...

HS: What was it like to be an artist with a small baby?

SHD: Oh. Well it wasn't easy.

$\mathrm{CD}: \mathrm{Mmm}$.

SHD: Its never easy. Umm...

CD: I was a pretty easy baby though I think, wasn't I?

SHD: Yeah.

CD: I wasn’t particularly difficult.

SHD: No.

JC: No, he just sat over in the corner.

Tend to break in skin

HS: Did he like to be in your studio or where did you work?

SHD: I had a little, they had a house. A nice house and I guess at the time it was a little bit new house.

HS: Are you talking about Microphylla mom?

SHD: Yeah.

CD: I can add to that. Ummm, when mom was living in Louisville, while she was going to U of L, etc. Umm, at her parent's house in St Matthews...

SHD: Whose house?

CD: Your parent's house in Saint Matthews. It went by the name, I don't know if it came with that name or did they name it Microphylla or was it already named Microphylla?

SHD: It was called that by the....

CD: Previous owners?

SHD: Mmm Hmm. 
CD: Okay. Anyway, that's the name of the property and umm. There was a second structure. Is it still there?

JC: No, not anymore.

CD: There's a second cottage, kind of like a guest's cottage and, it's a neat building actually. Kind of small-ish. Anyway, that was mom's studio while she was living in Louisville.

HS: In Louisville.

CD: Before she was married.

SHD: It was charming because it had a ....

CD: Fireplace in it?

SHD: Fireplace.

CD: And cathedral ceilings, it was really neat.

HS: Yeah.

CD: Not very large but it was perfect. And I had, it had pretty good lighting in there did it?

SHD: Mmm Hmm. Yeah.

CD: So that's what mom was referring to about this separate structure. Umm, she was living in New York City when she had me.

SHD: Now that's right.

CD: And she lived on Tenth Street. And that's, when I was born, she was living on Tenth Street with my dad, Wick. And, umm... so what was it like living in the city with dad and myself as a little thing doing, trying to paint. How did that work?

SHD: Well it worked. Having a baby is difficult.

CD: Just by itself, yeah.

SHD: And umm... 
CD: Did you get... Now if you wanted to, were there times, umm, during this period when we were living in New York City and I was just a little tot, a little thing, were there times when you had somebody watch me while you did painting?

SHD: No.

CD: No? You just kind of had me right nearby while you were painting probably, maybe. Kinda did.

SHD: Yeah. Kinda did.

CD: Mmm Hmm. So you kind of juggled both.

SHD: Mmm Hmm.

CD: Looking after me and painting.

SHD: Yeah. I looked after Wick too.

JC: Did you paint right in, uhh...

CD: In your apartment?

JC: In your apartment or did you go to a studio to paint?

SHD: In the apartment.

CD: In the apartment. On Tenth Street. Yep.

HS: I have a picture, Sally, of where you took him to a gallery.

SHD: Where? what?

HS: I have a picture of where you took Craig to a gallery and it's you and him.

CD: It's kind of a quasi-famous picture.

HS: Yeah, it's cute.

CD: You remember that one? You were wearing a sort of sharp, real red blazer and a white skirt.

SHD: Oh that.

CD: That's a family fave. 
SHD: Yeah. Laughs. I've been trying to decide what happened. This was, well somebody. I think it was...

JC: Was it the Corcoran? Or the Whitney?

CD: I think it might have been the Speed.

JC: The Speed. Maybe it was the Speed.

SHD: Mmm Hmm.

HS: It says...

CD: Because this was made into an announcement.

HS: Right, right, right.

CD: And what was that. What show was it? 2003.

HS: That's Corch... That's Mitchell Algus Gallery.

CD: Oh that was, this was for the show that you had at Mitchell Algus in New York City.

HS: In 2003.

SHD: Is this me?

CD: Mitchell Algus. That's not. That's. Let me be clear here. This particular announcement was for the show...

JC: The invitation was for the show.

CD: Yeah, the invitation was for the show by Mitchell Algus Algus in New York City. The photograph itself was taken, I believe, at the Speed. Is that what you would say?

HS: Mmm Hmm.

CD: That's what I thought.

SHD: Yeah, that's the Speed.

CD: That's what that is, the Speed?

SHD: Mmm Hmm. 
CD: Okay.

HS: Did Craig like to go with you?

SHD: Laughs. Not particularly.

Laughs

CD: It's a great photograph though.

SHD: I think it is.

JC: Do you have one around here, maybe? No?

CD: We may. I don't know.

SHD: What was the date?

CD: Oh.

HS: It doesn't have the date on it. The date for the show is later.

CD: It does say mid-sixties. Well that would make sense because I'm about four years old there so. And it does make reference to the Speed Museum as the location of the photograph on the thing.

JC: Oh.

HS: Even better.

CD: I see that. I have a real expression on my face there.

SHD: That's what sold me on the announcement.

CD: Oh that's what sold you on the announcement? Is the expression on my face?

Laughs

JC: A critic.

CD: Yeah. Art expert.

JC: Teentz, how involved was, uh... 
SHD: Wick?

JC: Grantz and Bob in the Speed. What did they, what did they do in the Speed.

SHD: incomprehensible-- was quite involved.

CD: Your father was quite involved?

JC: He was.

SHD: He liked it. To be involved in the art world.

JC: Yeah.

SHD: And he was.

CD: So did he, did he make some, I guess he probably dona... made some donations to the Speed probably.

SHD: Yeah, I think that he helped.

CD: Right.

SHD: He put up money and uh..

CD: Mmm Hmm.

HS: You want me to take it so it's out of your way?

SHD: Thank you. ... Yeah.

CD: So they were pretty, pretty involved.

HS: So it sounds like they always liked art, your parents.

SHD: Well mother always liked art. Mother was the one with the artistic feeling.

CD: And your father, your father, it sounds like your father, umm, he was led to appreciate it.

SHD: Mmm Hmm.

CD: Like he wouldn't necessarily be oriented that way but..

SHD: No. 
CD: But with a little bit of hand-holding or whatever, he did appreciate it.

SHD: Yeah. Oh yes, he did.

HS: So after you were married, before you were married-How often would you paint? How often would you sit down to make something?

SHD: Well, before I was marr... Before we had Craig we... More. I feel responsible, I felt responsible for his, for his bringing up.

CD: She had less time to devote to painting.

SHD: Wanted to know how often...

CD: I think that uh, as I recall, growing up, I think mom spent a good—and tell me if I'm wrong mom, in Ridgefield, Connecticut. Because I was only nine, I only lived in the city with mom and dad until I was nine months old and then we moved to Ridgefield, Connecticut when I was nine months old and as I was growing up I think that you, you put a good six hours, maybe more a day in front of the easel. That's my recollection.

SHD: Yeah. I don't think it was steadily.

CD: It might have varied some but she was...

SHD: Yeah.

CD: You know, that was her... That's what she did. I mean, she raised me, but, aside from that, that's what she did.

JC: She painted.

CD: She took care of the, kept very good, really nice house and cooked, did all the meals and everything like that but aside from those and looking after me. Aside from those things, she's a serious artist. There wasn't like, something to do, you know.

HS: So what kind of mood would you be in when you would sit down to paint? Did you find that it relaxed you?

SHD: What kind of music?

HS: What kind of mood? When you're sitting....

CD: Mood. 
HS: down and painting, how did you feel?

SHD: It's just something I did.

HS: Its just something you did.

SHD: Mmm Hmm. It wasn't a matter of taste. I just, I just, wanted to do it. And I was interested in it.

$\mathrm{CD}: \mathrm{Mmm}$ ?

SHD: I was interested in it.

CD: Mmm Hmm. It must have given you some sort of, not like pleasure but some satisfaction in doing that.

SHD: Yeah. Incomprehensible.

CD: It wasn't just a chore.

SHD: No no.

CD: Yeah. And I think you felt like you had something to say with your art. I found that, I feel that pretty strongly.

SHD: Yeah.

HS: What did you have to say with your art?

SHD: Ha.

CD: laughs

SHD: What did I have to say with my art...

HS: If its something, if sitting down and painting is something you felt that you had to do...

SHD: Yeah.

HS: Why did you feel that you had to do it?

SHD: I had to do it.

HS: You had to do it. 
SHD: Well, I think it was just and noble pursuit and there was a lot that I disapproved of.

HS: There's a lot you disapproved of?

SHD: Lots, lots that I didn't really enjoy.

$\mathrm{CD}: \mathrm{Oh}$, as far as the art that was around?

SHD: Mmm Hmm.

CD: That day. Oh.

HS: So you made something that you enjoyed.

SHD: Yeah.

CD: It sounds, sounds, it sounds to me like, to me mom that maybe one of your feelings at the time was that there wasn't a lot of, uh, great art out there and you felt like you, by you painting, making your paintings, producing your paintings, that was your effort at trying to produce art that you felt was a little more meaningful.

SHD: Yeah, I thought....

$\mathrm{CD}$ : Is that kind of true?

SHD: Kind of true. Oh yeah...

CD: Not to sound conceited or anything...

SHD: There wasn't any mission.

$\mathrm{CD}$ : You were not on any mission?

SHD: No.

CD: Yeah. But you had some motivation there obviously. Laughs. It takes a lot of patience to do those paintings...

SHD: Yeah. I know it. Yeah. It's ...

CD: Now did umm, I don't know if you want, she has more to her education story. I don't know if you want...

HS: Yeah, absolutely. Go ahead, we can go back to that. 
CD: Okay. Well mom did not graduate from Rollins.

SHD: No.

CD: She went there two years? Or is it one year?

SHD: Two I think.

CD: And then she took some courses and maybe she enrolled at some school outside of Washington, DC.

SHD: Oh yeah.

CD: But I don't remember the name of it.

SHD: Kingsmith School.

CD: Kingsmith School.

SHD: Mmm Hmm.

CD: And what, what was your, what interested you about going, what made you go there?

SHD: Umm.

CD: Where you taking any art courses there?

SHD: Oh, In Washington, in Washington. There was art schools.

CD: Mmm Hmm. Mmm Hmm.

SHD: Called Kingston School.

CD: Okay.

SHD: And, uh, it had been there a long time.

CD: Mmm Hmm.

SHD: I...

CD: So it was kind of an art school. 
SHD: Sort of, yeah.

CD: Okay, yeah. So it had a big focus on art.

SHD: One of the people that was, was, umm, a very good artist.

$\mathrm{CD}$ : Oh, one of the teachers? Or one of the students there was a very good, uhh.

SHD: Incomprehensible... was there.

CD: Okay what or who was there?

SHD: Yeah.

CD: There was a good artist at that school. Was it a student?

JC: Do you remember their name?

SHD: Umm. Let's see.

CD: I don't, I don't think mom is going to get that name. Because I've never...

JC: Its okay. That's fine.

CD: Yeah.

JC: I just thought I'd ask.

CD: Yeah, doesn't hurt.

HS: Now after Kingsmith, you went to the Institute of Design in Chicago?

SHD: Yeah.

HS: What was that like?

SHD: Oh. Daddy and I came to New York to look at art schools and, uh, Daddy didn't approve of, uh, most of the artists work that we saw.

HS: He didn't approve of the art schools or the artists work that he saw?

SHD: Yeah. Incomprehensible. You know it's terrible when you have, reminisce-you get so much that's wrong or isn't quite fit.

HS: That's the power of memory. 
SHD: Isn't it?

HS: Yeah.

SHD: And you, I don't feel that I ... Well lets see that...

JC: It's frustrating because you can't remember. Its there but you can't remember everything.

SHD: Well that's true. But uh...

HS: It's alright. And after that you went to U of L.

SHD: U of L.

HS: Yeah.

SHD: Oh, Oh. There's one period there in New York. Umm, I moved to New York and I was.... I adored the arts. I love New York. I still love New York. Huh. I do. I, I think its wonderful. I feel alive there. And umm, being in New York was a great stimulus. It is a wonderful place. Laughs.

JC: Makes you cry.

SHD: No, incomprehensible but I love it.

JC: Because it makes you feel alive?

SHD: Mmm Hmm. I think it's wonderful.

JC: Is it the people?

SHD: Yeah.

JC: The noise?

SHD: Well, I can't say that I love the noise but I like the people. I like the variety and umm, I've always loved variety.

HS: Do you think the paintings you made in New York are different than the work that you've made elsewhere?

SHD: A matter of timing. 
HS: Better timing?

JC: A matter of timing.

SHD: Time.

JC: Who was the umm, who was one of the most influential artists?

SHD: Incomprehensible.

JC: Who do you think influenced your work the most?

SHD: Well.

JC: That made you see better than anybody else.

SHD: Mostly, I think the influences was my teacher- teachers. I had an interesting teacher, I was more interested and then there was workers, like uh, I loved Ulfert Wilke work.

CD: You're talking about Ulfert Wilke's work you said?

SHD: Mmm Hmm.

CD: You really liked his work.

SHD: Yeah.

JC: You went to, uh, Italy to study.

SHD: Oh yes. That was wonderful.

JC: Why was that so wonderful?

SHD: Just to be there, to see the wonderful works of art.

CD: In Italy.

SHD: Its just fabulous.

CD: Uhh huh. That was inspiring to you.

SHD: Yeah.

CD: Obviously. 
SHD: Yeah. In fact, I didn't want to go look at any art.

CD: Mmm Hmm.

SHD: How do I put this? I didn't want to... Italy was wonderful.

CD: Mmm Hmm.

SHD: Let me see...

CD: You loved Italy.

SHD: I did.

CD: She lived in a small town called Perugia.

SHD: Mmm Hmm.

CD: Which is near...

HS: Venice?

CD: Is it near Venice mom?

SHD: Well its South. South of Venice.

CD: And, I imagine you know this, but uhh, she was, this was part of her Fulbright Fellowship.

HS: Mmm Hmm. And then you had a Guggenheim Fellowship later?

SHD: Yeah.

CD: I think that was actually a grant more than a fellowship?

SHD: Yeah. I think so.

CD: Where she could. I think she had the choice of taking a lump sum amount of money or a year paid for in France for her and her family.

SHD: Mmm Hmm.

JC: Which did she take? 
CD: She took the year in France. Absolutely, the South of France.

SHD: Mmm.

CD: The south of France. The south of France, Lacoste.

SHD: Yeah, what was it about the south of France.

CD: We lived in Lacoste.

SHD: Oh, that was another time.

CD: Well we were, she was... Hillary was mentioning that not only did you win the Fulbright Fellowship, where you went to Italy, 1952 or so, later on you also won a Guggenheim Grant in the mid-sixties.

SHD: That's right.

CD: Where they, they put you and dad and myself up for a year in Lacoste.

SHD: Yeah.

CD: Which is in the South of France, I believe. I'm sure...

SHD: Mmm Hmm. It was. A small town.

HS: Now you liked the work there.

SHD: Uh Yeah. It wasn't easy.

CD: What was not easy?

SHD: Well, we had to find a place to live.

CD: Mmm Hmm.

SHD: Had to find a place to live and paint and raise a family.

CD: Family. Mmm Hmm.

SHD: You know.

CD: Wasn't easy. Figuring that all out.

SHD: Yeah. 
CD: Mmm Hmm. And we uh, it was, it was a, I mean I don't remember much of it because I was only five. But it was just though, it was just really so bucolic.

SHD: Yeah.

CD: Yeah, we had like lavender fields that we looked out upon, it was quite rural. We had um, they lived, the house that we lived in was like about a 500 year old stone house.

SHD: Yeah.

CD: It was incredible you know? And uh beauty, charming, beautiful architecture, country and country style and then the neighbors - our next-door neighbors, we only, we only had one set of next store neighbors as I recall. That also own a very old structure.

Umm, his name was Javert.

SHD: Mmm Hmm.

CD: The, the father and he used to, I used to hang out with him

SHD: Ha ha.

CD: In the afternoon and then there was an almond tree...

SHD: Mmm Hmm.

CD: On our property. And we would, I don' t know, I think he had a loaf of bread. I don't know, he would talk to me and stuff. I was only five.

JC: In French?

CD: Probably. Probably.

SHD: Who talked?

CD: Javert I think, I hung out with Javert a little bit.

SHD: He used...

CD: This older man who, I don't know, in his fifties or something.

JC: Old man.

CD: When I was that, when I was, I wouldn't say that now but compared to me then he was an old man. 


\section{Laughs}

CD: But, uh, anyway. It was just, just a incredible setting and mom had a, she had her own studio there, a separate room that you painted in.

SHD: Yeah, you know. It would, the... I had a.. very... house.

CD: I'm sorry. Not that it matters a lot. Emile. Was that his name?

SHD: Emile?

CD: The neighbor?

SHD: Yeah.

CD: Emile. Not that it matters that much. Anyway, you painted while you were there.

SHD: Oh yeah.

CD: Right?

SHD: I had a small studio.

CD: Little room? A small studio? A little room for a studio.

JC: What paint, do you recall which paintings you painted there.

SHD: Yeah. I painted.

$\mathrm{JC}$ : Where you painting dots then?

CD: Hmm Mmm.

JC: You were then.

SHD: I guess so.

CD: She definitely got over to pointillism by then. She, she she had gotten to pointillism in the $50 \mathrm{~s}$.

HS: Yeah.

JC: Yeah. 
HS: Right, right, right.

JC: That's why she got there.

SHD: Yeah.

JC: Right.

CD: Right.

HS: Now Sally let me ask you a question. You said that you started making your paintings because you didn't like what you saw, what other artists were making, how was your work different than what everybody else was making?

SHD: Well, in painting, my feeling was that, I feel that looking back on it now that I didn't like the work.

CD: I'm sorry, what was your, what was your...

HS: So, Sally said that she started painting because she didn't like what, the other paintings that were around at the time, so I was asking what was different about her work.

CD: Right. Mmm. Oh, okay. How did your work differentiate with the other work that was being done at the time?

SHD: I was, uh, trying, I wasn't sure of anything then. I wasn't sure. I think I was always doubtful.

CD: You had, you had reservations about the work that was being done at the time.

SHD: And my own work too.

CD: And naturally, I'm sure a lot of artists do that. Can you say what made your artwork different?

SHD: Well, umm...

JC: Or what you were trying to do that other people weren't doing.

SHD: Oh, I don't think I would have put it quite like that because I don't think I was ever. I didn't think I was special.

CD: You didn't think you were special?

SHD: No. 
CD: Okay. You're humble.

SHD: laughs yeah. Humble.

Laughs

CD: But do you remember, umm, and we'll let it go after this, I won't try to analyze it too crazily but did you have, just kind of very general, broad terms...

SHD: Oh, they were sort of, light.

CD: There was what?

SHD: There were certain paintings I liked.

CD: Certain painters that you liked. Mmm Hmm.

SHD: One was, I liked Ulfert's work.

CD: You like Ulfert's work. Uh huh.

SHD: And, umm, umm, what was his name...

CD: De Kooning?

SHD: Yeah, I liked De Kooning's work.

CD: You liked De Kooning's work.

SHD: I still like it.

CD: Still like it. Yep.

JC: Did you like his, did you like, which De Kooning?

SHD: Which?

JC: Which one?

$\mathrm{CD}$ : Any particular ones that you can recall?

JC: No no. Which De Kooning.

SHD: Oh. 
JC: Mrs. De Kooning or Mr. De Kooning?

SHD: Mr. De Kooning.

CD: Mr.?

JC: Which De Kooning's work did you like? Did you...

CD: Oh they both were artists?

HS: Mmm Hmm.

JC: Yeah.

SHD: The man and the woman?

JC: Right.

SHD: Oh, the man.

JC: The man. You know he's the most famous.

SHD: Yeah.

JC: But uh...

SHD: He' s a better painter too.

JC: Well, there you go.

CD: Well she likes that there.

JC: That's going to say...

HS: Well Sally is there anything that I haven't asked you that you're just dying to get out or express?

SHD: Oh, probably but I can't think what it is.

CD: Do you have anything in, on your mind now that you, like this second that, that you'd like to add or share?

SHD: I had a lot of enthusiasm. It was all native. I had a lot of enthusiasms. 
CD: She had a lot of enthusiasm.

SHD: For certain painters like, well, let me see, who do I ...

CD: Well you like, let's see, I mean, you liked Seurat did you?

SHD: Oh yeah. All those, that gang. I liked them a lot.

CD: Mmm Hmm. Any other particular artists that really, that stand out, like really inspired you? Like, like, you know, what comes to mind?

SHD: Umm, I liked, well, De Kooning, you mentioned.

CD: Yeah. Any other big heavy hitters out there that just, 'oh yeah, I love that guy.' You know, like Matisse or...

SHD: I like Matisse.

CD: Mmm Hmm. Does any, any of them have like a, you have a soft spot for? You can name a couple names. You know, it doesn't have to be one.

SHD: I liked...

CD: Monet? I don't know.

SHD: Yeah.

CD: There's Manet also.

SHD: French bunch.

CD: You like the French painters?

SHD: Mmm Hmm. I like, school, the school of painting of them.

CD: French art?

SHD: Mmm Hmm.

CD: Oh. Okay.

SHD: I do.

CD: Mmm Hmm. 
SHD: And I like the taste.

CD: Mmm Hmm.

SHD: Taste would be a bad word but I use it a lot.

CD: That's alright.

SHD: Mmm.

JC: What did you think of Lois' work?

SHD: Umm...

CD: I know you like it.

SHD: I do. I like it. Umm...

JC: Would you call her a contemporary artist or...

SHD: Yeah. I think I would.

JC: It was different than your work. She approached it differently than you.

SHD: Yeah. She was more traditional.

CD: More traditional?

SHD: Traditional.

CD: Mmm Hmm.

JC: Do you ever debate with her over, over art?

SHD: No.

HS: Was there anything else you want to say about being an artist or about your work?

SHD: Well let's see, is there anything I want to say about being an artist...

CD: I know, I know that over the years mom, in you know, over the last twenty years, not that you and I have talked about art a whole lot, but...

SHD: Not a whole lot. 
CD: More so over the last couple years though because I've developed an interest.

SHD: Yeah.

CD: An appreciation of art. It had, I think it had something to do with moving to the area, being closer by, and just getting older and stuff. But anyway umm, I remember a common statement by you was that you felt like, as far as the modern art that's out there, there's a lot of, you didn't use the work junk, but you...

SHD: But I meant it though.

Laughs

JC: Oh, that's cute.

CD: And also, umm, I think you felt that the art market, something, something like, it was just too trendy, like Joe Blow, like maybe certain styles or types of art got popular and there's just a lot of herd mentality that unthinking uncritical mentality about art that made certain types of art sell. If that makes any sense. That's what I got from you that you felt that too often there's art that 'oh yeah that's great art, that's great art,' but it was kind of, I mean there wasn't enough thought and critical, umm, critical, uh, perspectives on a lot of modern art.

JC: Maybe approach it this way, what makes good art?

SHD: Well...

CD: You know it when you see it right?

SHD: Yeah.

JC: Well, no. I think you know. What makes good art.

SHD: To whom? To whom I'd say.

CD: In your opinion.

SHD: Oh, to me?

CD: Mmm Hmm. Are there certain qualities that strike you that...

SHD: Yeah.

CD: Such and such a piece is a.... 
JC: Is it more about, is it about the person?

SHD: It's always about a person. Isn't it?

JC: Well, I, I, I guess I'm trying to think. You know, uh...

SHD: Some art I like, some I don't like. There was a popular painter that I knew in Italy.

CD: That you knew in Italy?

SHD: Uhh huh.

$\mathrm{CD}$ : Mmm Hmm. And what did you think of his art? You said that he was popular at the time...

SHD: He was popular among artists.

$\mathrm{CD}$ : Among artists. Among artists he was popular. Mmm Hmm. And what did you, did you like his stuff?

SHD: No.

CD: You did not like his stuff.

SHD: No.

CD: Uh huh.

$\mathrm{JC}$ : And why is that?

SHD: Well you know it was...

CD: Moms checking out the drink. Now, I was just going to, the education part, we didn't really fully complete that.

SHD: No.

CD: She went to Institute of Design, its called, in Chicago.

HS: Mmm Hmm.

CD: She also, I don't know what the sequence was, but then you also went to the University of Columbia. Columbia University.

SHD: Yeah. 
CD: And, umm, I believe you got a...

SHD: I liked it a lot. I loved being in New York knowing artists but I love being in New York period.

CD: Just overall. It was a great time to be in New York.

SHD: It really was.

CD: And you liked being....

SHD: Oh, and Tenth Street was very nice. Laughs

$\mathrm{JC}$ : What was so nice about that?

SHD: They're artists. Serious artists lived and worked there on Tenth Street.

JC: Who were your favorite guys that were in your group?

SHD: Oh, De Kooning. De Kooning. De Kooning. De Kooning.

JC: You met him, you knew him.

SHD: Well I met him.

CD: De Kooning, yeah.

SHD: Mmm.

CD: But you also, umm...

SHD: I also knew lousy artists.

CD: You also knew lousy artists, is that what you said?

SHD: Mmm Hmm.

CD: Okay. Well.

JC: There are more lousy ones than good ones probably, no?

SHD: Oh yeah. Mmm Hmm.

CD: And umm... 
JC: Is it because they, they were, they oversold their art or they just, they didn't, or they never had...

SHD: No, never any talent and when I was living in New York, I went to quite a few artists' shows.

CD: I bet you did.

SHD: And, umm, Tenth Street was also lively in those days.

CD: Lively. Lively.

JC: Yep.

SHD: It had good openings.

CD: Good openings, uh huh.

SHD: Mmm Hmm.

CD: Well attended and....

SHD: Cheap wine.

CD: Cheap wine?

Laughs

HS: Not tonight, no cheap wine tonight.

CD: Johnny bought a couple of nice bottles of wine

SHD: No cheap wine? Good.

HS: Do you all have any last minute questions, anything you can think of?

JC: No. Well you know, if we can pick up something here and you know, you'll just have to remember it.

CD: Right, and umm...

JC: I tell you one thing that umm, Craig, did you dig out any of those uh....

CD: I didn't have a chance yet, I'm... 
HS: Right, I think we're pretty much done here so I'll go ahead and shut this down and then we can get ready for dinner or whatever we need to.

CD: Okay, alright, great.

HS: Is that okay with you, are you ready to stop?

SHD: Yeah.

$\underline{\text { Session } 4}$

JC: Other artist's fathers and families or...

SHD: I really don't know.

JC: That's okay.

SHD: I don't remember.

JC: How about who supported, Lois' family, did they support her? Lois Dodd.

SHD: Lois Dodd has been successful.

CD: Successful?

JC: I know she...

CD: Johnny was asking did she have, what was her level of support from her family? Do you have any idea?

SHD: I know the support came from her.

JC: She did it all by selling paintings. Really?

SHD: Yeah. And she... I...

JC: Yeah.

CD: You're going to love talking to Lois have you, have you spoken to her yet?

HS: I've not spoken to her yet. So what we're going to do is umm, do a phone conversation and then probably she's going to be contributing to the catalogue as well. 
CD: Yeah. That's great.

HS: But we're still working out in what capacity...

CD: She's really great.

SHD: She knows a lot. She's very accurate.

CD: She's just a cool person. Everybody likes Lois.

SHD: And she does remember well.

JC: Her memory will be good?

SHD: Yeah.

CD: Yeah.

SHD: I think so.

JC: Yeah. Cool.

CD: Did you meet her through the Tanager? Was that how you met her? I'm guessing.

SHD: Yeah.

JC: Well.

SHD: We had wonderful openings.

CD: Fun right?

SHD: Yeah.

CD: There's a photograph somewhere, it's framed, I'm not, I have no idea if it's up or not, it was up, of a reunion of the Tanager people. I think back, I think it was in the 90s.

$\mathrm{JC}:$ Oh really?

CD: Yeah.

JC: You have a picture around here somewhere?

CD: Yeah, somewhere around here, framed. 
JC: Oh, I'd love to see it.

CD: Yeah, I can't begin to, I know where...

SHD: I think it's in...

CD: It was, I kind of think its not hanging right now but it exists and it's framed and its cool.

JC: Well it might be interesting for this catalogue as an option. I'm not sure if she's going to use it or not but it'd be an option.

CD: Right.

JC: Love to, love to, I'd love to copy it, if I could because I can do that.

SHD: I know where it is.

JC: Just to have.

CD: It was hanging, I believe, in your studio.

SHD: Yes.

CD: But I'll take a look. It's just nice that they got together after about fifty years or whatever it was.

HS: Yeah.

SHD: Oh you mean incomprehensible.

CD: Remember? Black and white photograph?

SHD: Yeah.

CD: You know, I bet, I bet you if I can't find the physical thing, I wouldn't be surprised, well, you know, maybe Phil Alexandre has some access to it. I don't know.

JC: Oh, okay.

CD: But it was neat that they got back together. I think it's a real, realtor's office now.

SHD: Mmm Hmm.

CD: Or when you went back. 
JC: Oh, the Tanager is now a realtor's office?

CD: Yes. Yep, yep, yep, yep. And the whole neighborhoods gotten all fancy dan, you know.

JC: Right.

CD: Not like it used to be.

JC: It's the east village right? I mean, you know.

SHD: East?

$\mathrm{CD}$ : Is it east village?

SHD: I would not say east.

CD: Its part of the village but not east village.

JC: Okay. I don't know why they don't call it the east village, because I guess the Tenth Street ...

SHD: Because it used to be, it was south of Broadway and it was south.

CD: Mmm Hmm.

JC: Where, where was your apartment on, uh, in, you were on East Tenth Street. You lived on East Tenth Street.

CD: 111 Right?

JC: 111 East

CD: 111 East Tenth Street. And, so you're right. About how many blocks would you say it was from the Tanager?

SHD: Oh about...

CD: Or how long a walk? How far away is it?

SHD: Umm...

CD: 15 minute walk? 
SHD: Yeah.

CD: Mmm Hmm. Was it on the other side of, is it, what splits east and west, Broadway? You know, east tenth from west tenth...

SHD: Yeah.

CD: What's the dividing road? Broadway or Fifth Ave?

SHD: Broadway.

CD: Broadway?

SHD: I think. 


\section{SALLY HAZELET DRUMMOND}

Born: 1924, Evanston, Illinois

\section{Education}

Rollins College, 1942-44

Columbia University, B.S. 1948

Institute of Design, Chicago 1950

University of Louisville, M.A. 1952

\section{Grants}

Fulbright, Venice 1952-1953

Guggenheim Fellowship, Lacoste 1967-68

\section{One-Person Exhibitions}

2015

2005

2003

2000

1990

1989

1984

1981

1978

1972

1972

1968

1962

1960

1957

1955

1955

1952
Hite Art Institute, Louisville, KY

Alexandre Gallery, New York, NY

Mitchell Algus Gallery, New York, NY

Mitchell Algus Gallery, New York, NY

Louisville Visual Arts Association, Louisville, KY

The Cornell Fine Arts Center, Rollins College, Winter Park, FL Artists Space, sponsored by the Mark Rothko Foundation, New York, NY

The Aldrich Museum, Ridgefield, CT

Fischbach Gallery, New York, NY

Corcoran Gallery of Art, Washington D.C. Retrospective

Fischbach Gallery, New York, NY

Fischbach Gallery, New York, NY

Green Gallery, New York, NY

Tanager Gallery, New York, NY

Tanager Gallery, New York, NY

Art Center Gallery, Louisville, KY

Tanager Gallery, New York, NY

Art Center Association, Louisville, KY

Hadley Gallery, Louisville, KY

\section{Select Group Exhibitions}

2015 Reductive Minimalism: Women Artists in Dialogue, 1960-2014, University of Michigan Museum of Art, Ann Arbor, MI 
Invitational Exhibition of Contemporary Art, American Academy of Arts and Letters, Jimmy Ernst Award in Art, New York, NY Optic Nerve- Perceptual Art from the 1960s, Columbus Museum of Art, Columbus, $\mathrm{OH}$

1994 Sally Hazelet Drummond and Truman Egleston, 5 Points Gallery, East Chatham, NY

1990 Surface \& Proportion, Margarete Roeder Galllery, New York, NY Sally Hazelet Drummon, Paintings, Susana Viola Jacobson, Paintings and Fran Riche, Photographs, Washington Art Association, Washington Depot, CT Sally Hazelet Drummond, Oil Paintings and Jon Cooper Ippolito, Pastels, Watercolors, Oils, Springfield Art Association, Springfield, $\mathrm{OH}$ The Kentuckians, Owensboro Museum of Fine Art, Owensboro, KY

National Arts Club, New York, NY Underknown, curated by Henry Geldzahler, P.S. 1, New York, NY The Gathering of the Avant Garde: The Lower East Side, 19481970, Kenkeleba Gallery, New York, KY Abstract Paintings of the 1960s, P.S. 1, New York, NY Speicher and Hassam Fund Exhibition, American Academy of Arts and Letters, North Gallery, New York, NY $31^{\text {st }}$ Annual New England Exhibition of Painting and Sculpture, New Canaan, CT

Paintings by George Chaplin and Sally Hazelet Drummond, Bethel Gallery, Bethel, CT

$197710^{\text {th }}$ Street Days: The Co-ops of the 1950s, Pleiades Gallery, New York, NY Bridgeport, CT A Change of View, Aldrich Museum, Ridgefield, CT Focus-Women's Work: American Art, Philadelphia Civic Center, Philadelphia, PA 
1971 Lyrical Abstraction, Whitney Museum of American Art, New York, NY

$197021^{\text {st }}$ Annual New England Exhibition of Painting and Sculpture, Silvermine, CT

1969 Albright-Knox Art Gallery, Buffalo, NY

Recent Trends in American Art, The Westmoreland County

Museum of Art, Greensburg, PA

1967 Focus on Light, New Jersey State Museum, Trenton, NJ

Sally Hazelet Drummond, Henry Koehler: Two Louisvillians

Active in New York, J.B. Speed Art Museum, Louisville, KY

1966 Current Trends in American Art, Westmoreland County Museum

of Art, Greensburg, PA

1964 Recent Acquisitions, Whitney Museum of American Art, New York, NY

1963 Americans '63, Museum of Modern Art, New York, NY

1962 Lyric Abstraction in America, American Federation of Arts

Travelling Exhibition

Recent Acquisitions, Museum of Modern Art, New York, NY

1961 The Private Myth, Tanager Gallery, New York, NY

Green Gallery, New York, NY

Louisville Art Center Annual, Louisville, KY

1960 American Artists Annual, Whitney Museum of American Art, New

York, NY

Tanager Gallery, New York, NY

1959 Tenth Street Artists Invitational, Museum of Fine Arts, Houston, TX

Tanager Gallery, New York, NY

1958 Fulbright Artists, American Federation of Arts Traveling

Exhibition

Tanager Gallery, New York, NY

1956

1955

Paintings and Sculpture, Tanager Gallery, New York, NY

Stable Gallery, New York, NY

Tanager Gallery, New York, NY

$1953 \quad$ Fulbright Artists, American Embassy, Rome, Italy

Foreign Artists Invitational, Boridghiera, Italy

1951 Barone Gallery, New York, NY

Stable Gallery, New York, NY

\section{Collections}

Chase Manhattan Bank, New York, NY

CIBA-GEIGY, New York, NY

Citizens Fidelity Bank, Louisville, KY

Corcoran Gallery, Washington, D.C.

Hirshorn Museum and Sculpture Garden Museum, Washington, D.C. 
Hite Art Institute, University of Louisville, Louisville, KY

Hudson Department Store, Detroit, MI

J.B. Speed Art Museum, Louisville, KY

Metropolitan Museum of Art, New York, NY

Museum of Art, University of Iowa, Iowa City, IA

Museum of Modern Art, New York, NY

University of Pennsylvania, Philadelphia, PA

Weatherspoon Art Gallery, University of North Carolina, Greensboro, NC

Whitney Museum of American Art, New York, NY 


\section{CURRICULUM VITAE}

Hillary Sullivan

1738 Spring St Jeffersonville, IN 47130

Hillary.sullivan@aol.com 435-881-6636

\section{Education}

2015

Master's of Arts, Critical and Curatorial Studies, University of Louisville

2014

Art Education Study Institute: Creating Pathways with the Dinner Party, Kutztown University

2012

Bachelors of Arts, Art History, Utah State University

\section{Professional Expereince}

2015

Curatorial Intern, National Infantry Museum, Fort Benning, Georgia

Curatorial Intern, Louisville Metro Commission on Public Art, Louisville, Kentucky

2015

Interior Design Support, Tassels LLC, Louisville, Kentucky

2014-2015

Graduate Assistant, International Honor Quilt, Hite Art Institute, University of Louisville, Louisville, Kentucky

2014

Curatorial Assistant, Conrad Caldwell House Museum, Louisville, Kentucky

2012

Intern, Estate of Anita Steckel, New York City, New York

2012

Teacher's Assistant, Utah State University, Department of Fine Arts, Logan, Utah 
Curatorial Intern, Howard Steamboat Museum, Jeffersonville, Indiana

\section{$\underline{\text { Exhibitions }}$}

MA Thesis, Iconoclastic Fervor: Sally Hazelet Drummond's Road to Abstraction

Schneider Galleries, University of Louisville, November 19- December 18, 2015

Louisville's First Museum: Public Art and the Louisville Free Public Library

Louisville Commission on Public Art, Online, 2015

Larry and LaDonna Was Here: the Artist Collector Relationship

The Kentucky Museum of Art and Craft, March 6 $6^{\text {th }}$ - April 12th, 2015

Louisville's River

The Conrad Caldwell House Museum, October 12th, 2014 - May 31 ${ }^{\text {st }}, 2015$

\section{Publications}

Iconoclastic Fervor: Sally Hazelet Drummond's Road to Abstraction

Exhibition Catalogue, Louisville, Kentucky 2015

The Untold Tale of Bob Lockhart: A Retrospective

Exhibition Catalogue, Louisville, Kentucky 2014

Contributor to "Lockhart Glossary"

\section{Invited Talks}

"The Dialectics of Public Art: Louisville and Beyond"

March 25, 2015, University of Louisville, Louisville, Kentucky

\section{Associations and Projects}

TEDx UofL 2015: Interconnected

Assistant Director

Aegis, University of Louisville Graduate Student Organization Member

American Alliance of Museums

Student Member 


\section{Awards}

Outstanding Graduate in Fine Arts, Hite Art Institute, University of Louisville, 2015

Center for Arts and Culture Partnership Scholar, University of Louisville, 2015

Cressman Scholar, Hite Art Institute, University of Louisville, 2014-2015 